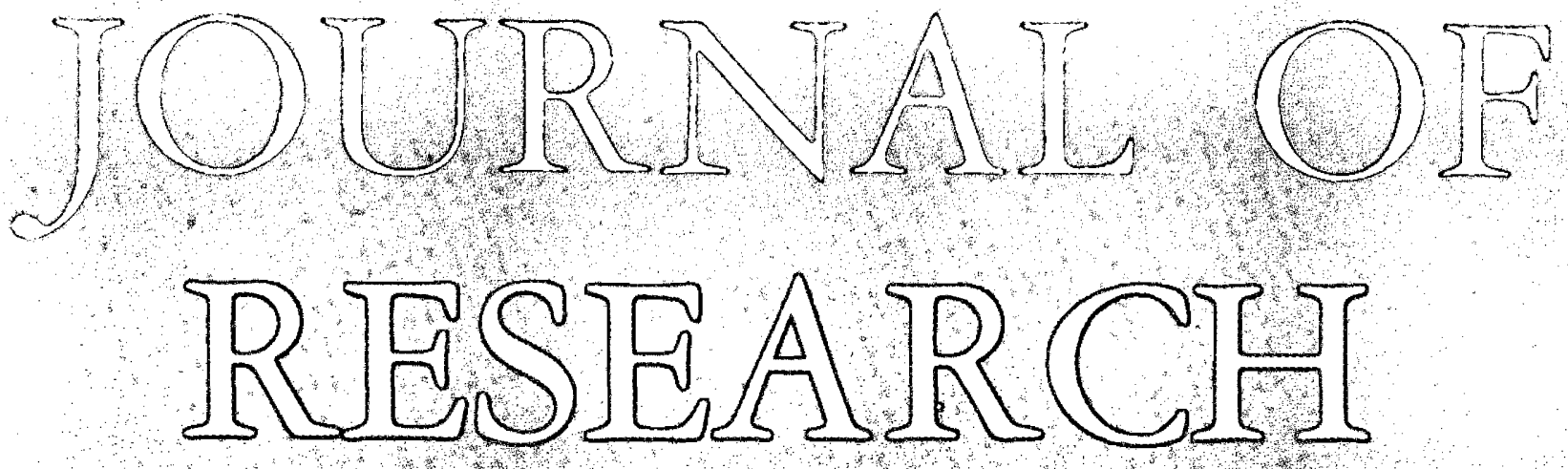

OR THE U.S. GEOLOCICAL SURVEY

JULY-AUGUST 1974

VOLUME 2, NUMBER 4

Scientific notes and summaries

of investigations in geology,

bydrology, and related fields 


\section{UNITED STATES DEPARTMENT OF THE INTERIOR}

ROGERS C. B. MORTON, Secretary

GEOLOGICAL SURVEY

V. E. McKelvey, Director

For sale by the Superintendent of Documents, U.S. Government Printing Office, Washington, DC 20402. Order by SD Catalog No. JRGS. Annual subscription rate $\$ 15.50$ (plus $\$ 3.75$ for foreign mailing). Single copy $\$ 2.75$. Make checks or money orders payable to the Superintendent of Documents.

Send all subscription inquiries and address changes to the Superintendent of Documents at the above address.

Purchase orders should not be sent to the U.S. Geological Survey library.

Library of Congress Catalog-card No. 72-600241.
The Journal of Research is published every 2 months by the U.S. Geological Survey. It contains papers by members of the Geological Survey and their professional colleagues on geologic, hydrologic, topographic, and other scientific and technical subjects.
Correspondence and inquiries concerning the Journal (other than subscription inquiries and address changes) should be directed to the Journal of Research, Publications Division, U.S. Geological Survey, National Center 321, Reston, VA 22092.

Papers for the Journal should be submitted through regular Division publication channels.

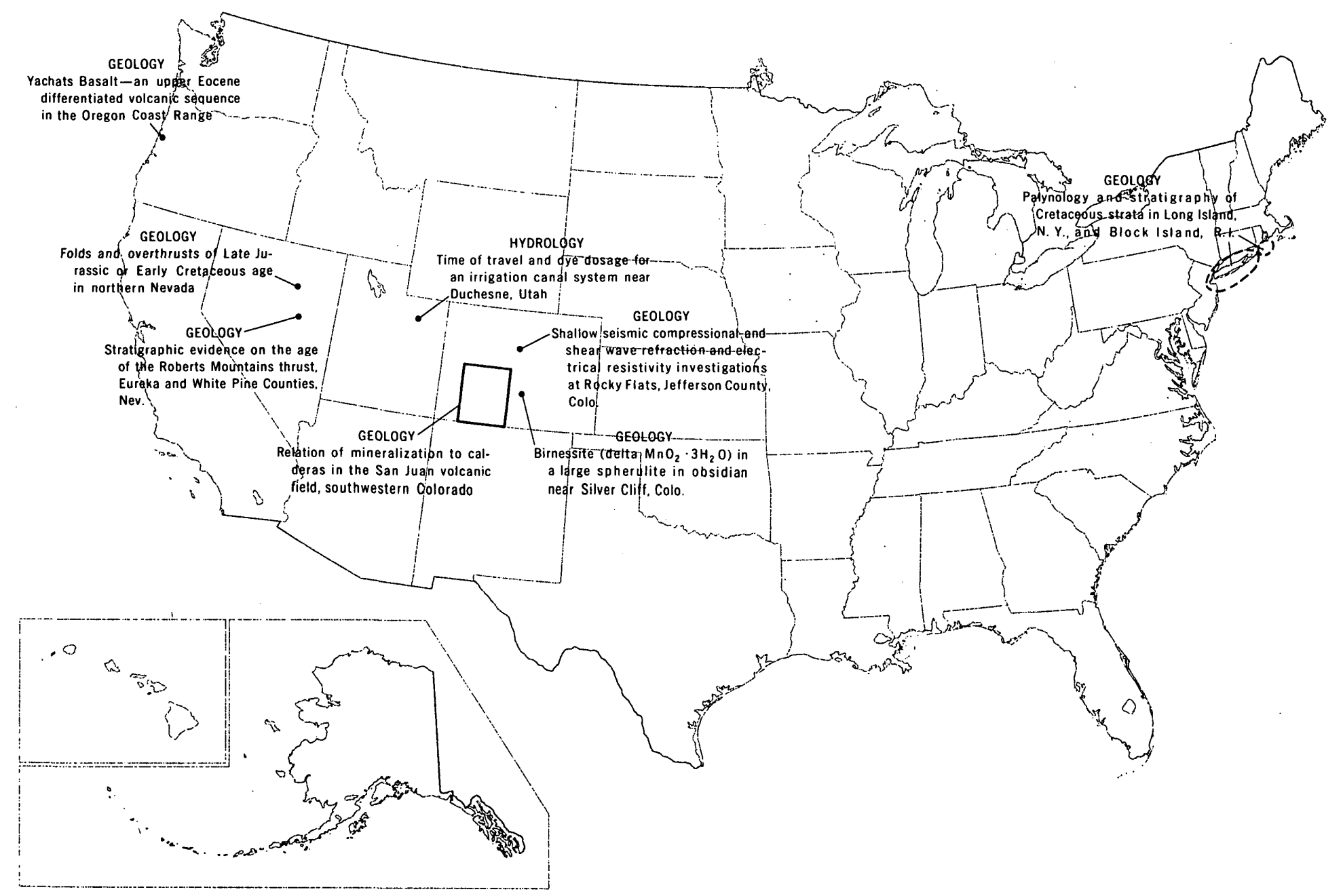

GEOGRAPHIC INDEX TO ARTICLES

See "Contents" for articles concerning areas outside the United States and articles without geographic orientation. 


\title{
JOURNAL OF RESEARCH
}

\author{
of the
}

U.S. Geological Survey

Vol. 2 No. 4

July-Aug. 1974

\section{CONTENTS}

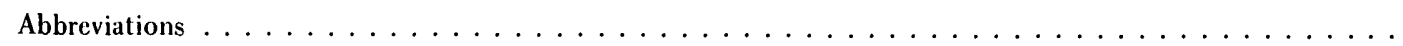

TOPOGRAPHIC STUDIES

The cartographic and scientific application of ERTS-1 imagery in polar regions $\ldots \ldots \ldots \ldots \ldots$ $\ldots \ldots \ldots \ldots \ldots \ldots \ldots \ldots \ldots \ldots \ldots \ldots \ldots \ldots \ldots$. Southard and W. R. MacDonald

\section{GEOLOGIC STUDIES}

Yachats Basalt-an upper Eocene differentiated volcanic sequence in the Oregon Coast Range . . . . . . . . .

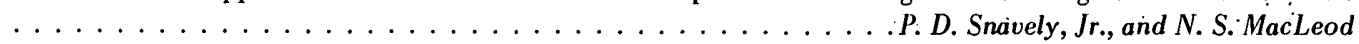

Relation of mineralization to calderas in the San Juan volcanic field, southwestern Colorado . . . . . . . . . . . . . . . . . . . . . . . . . . T. A. Steven, R. G. Luedke, and P. W. Lipman

Stratigraphic evidence on the age of the Roberts Mountains thrust, Eureka and White Pine Counties, Nev. . . . . $\ldots \ldots \ldots \ldots \ldots \ldots \ldots \ldots \ldots \ldots \ldots \ldots$. . . . . . . . . . . . . . . . . . . . . . .

Folds and overthrusts of Late Jurassic or Early Cretaceous age in northern Nevada $\ldots \ldots \ldots \ldots \ldots \ldots$ $\ldots \ldots \ldots \ldots \ldots \ldots \ldots \ldots \ldots \ldots \ldots \ldots$ Ketner and $J . F$. Smith, Jr.

Shallow seismic compressional and shear wave refraction and electrical resistivity investigations at Rocky Flats, Jefferson County, Colo. . . . . . . . . . . . . . . . . . . . . . H. D. Ackermann

Palynology and stratigraphy of Cretaceous strata in Long Island, N.Y., and Block Island, R. I. . . . . L. A. Sirkin Energy dispersive spectrometry for quantitative mineralogical analyses-an ancillary system on an electron

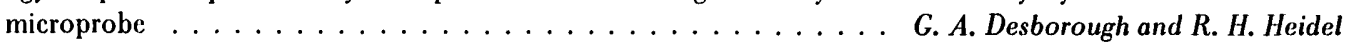
Activity-product constants of aragonite at $90^{\circ}$ and $51^{\circ} \mathrm{C} \ldots \ldots$. M. Siebert, P. B. Hostetler, and C. L. Christ Equilibria of cinnabar, stibnite, and saturated solutions in the system $\mathrm{HgS}_{-} \mathrm{Sb}_{2} \mathrm{~S}_{3}-\mathrm{Na}_{2} \mathrm{~S}-\mathrm{H}_{2} \mathrm{O}$ from $150^{\circ}$ to $250^{\circ} \mathrm{C}$ at 100 bars, with implications concerning ore genesis . . .R. E. Learned, George Tunell, and F. W. Dickson Birnessite (delta $\mathrm{MnO}_{2} \cdot 3 \mathrm{H}_{2} \mathrm{O}$ ) in a large spherulite in obsidian near Silver Cliff, Colo. . . . .F. A. Hildebrand Mineralogical studies of the nitrate deposits of Chile. IV. Brüggenite, $\mathrm{Ca}\left(\mathrm{IO}_{3}\right)_{2} \cdot \mathrm{H}_{2} \mathrm{O}$, a new saline mineral . . . $\ldots \ldots \ldots \ldots \ldots$. . . . . . . . . . Ericksen, M. E. Mrose, and J. W. Marinenko

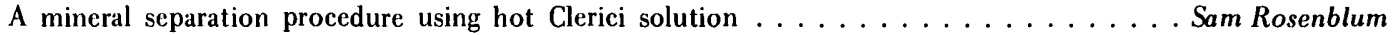

A sensitive and rapid method for the determination of trace amounts of selenium in geologic materials. . . . . .

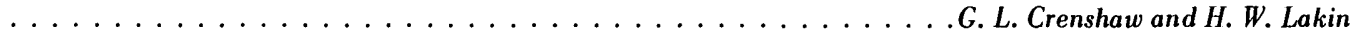

\section{HYDROLOGIC STUDIES}

Time of travel and dye dosage for an irrigation canal system near Duchesne, Utah . . . . . . . D. B: Adams Generalization of stream travel rates and dispersion characteristics from time-of-travel measurements . . . . . . $\ldots \ldots \ldots \ldots \ldots \ldots \ldots \ldots \ldots \ldots \ldots \ldots \ldots \ldots \ldots \ldots \ldots$ Boning

Recent publications of the U.S. Geological Survey $\ldots \ldots \ldots \ldots \ldots \ldots$ Inside of back cover 


\section{ABBREVIATIONS}

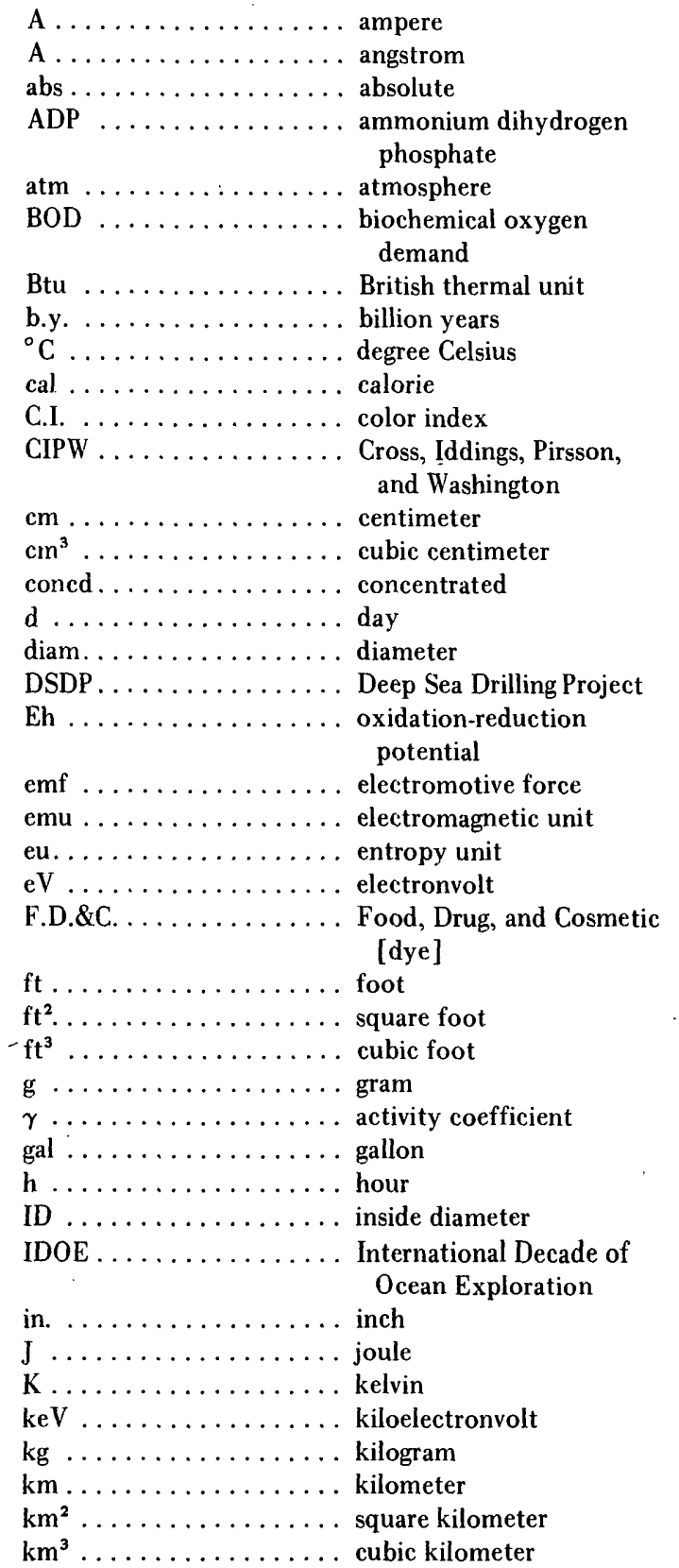

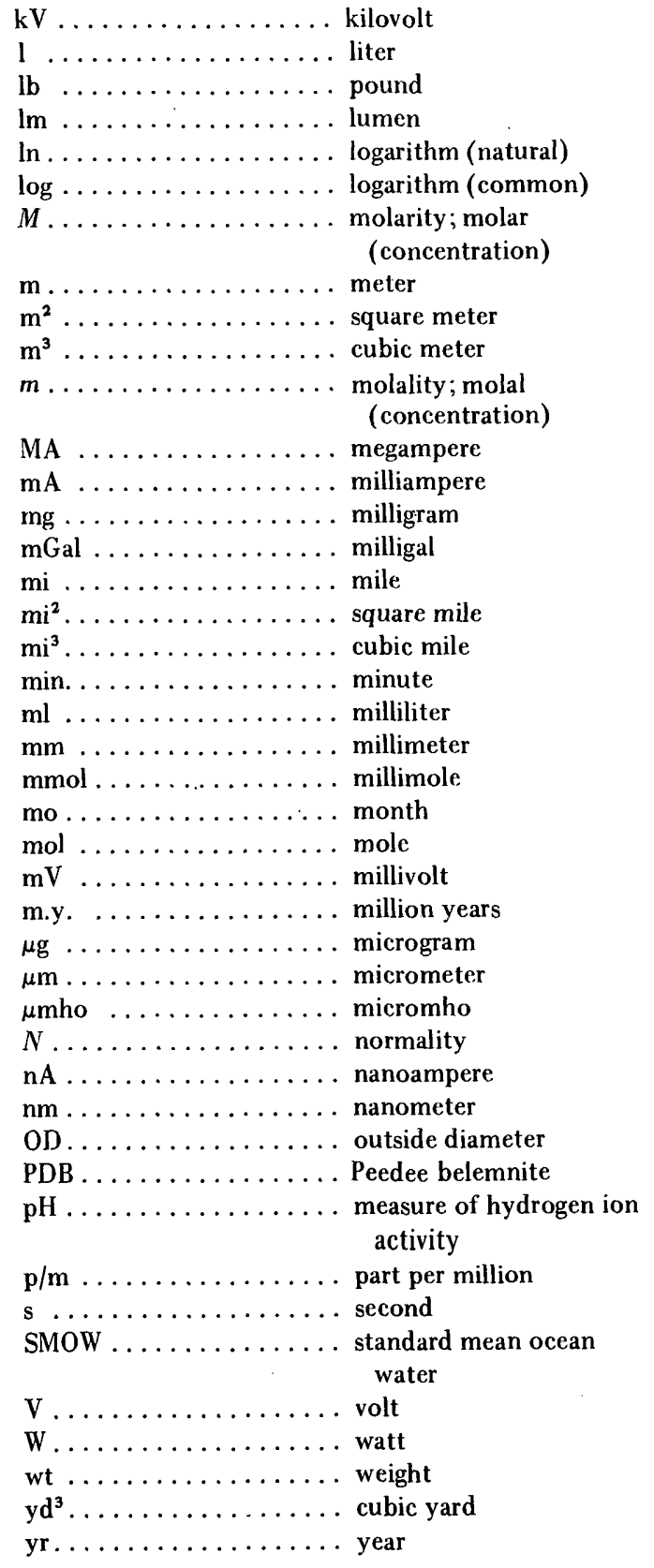




\title{
THE CARTOGRAPHIC AND SCIENTIFIC APPLICATION OF ERTS-1 IMAGERY IN POLAR REGIONS
}

\author{
By RUPERT B. SOUTHARD and WILLIAM R. MacDONALD, Washington, D.C.
}

\begin{abstract}
The first Earth Resources Technology Satellite (ERTS-1), launched by the National Aeronautics and Space Administration in.July 1972 , is providing valuable data for investigations of the most inaccessible and hostile regions of the Earth-the Arctic and Antarctic. ERTS images and map products derived from them offer a whole new dimension in source material for multidiscipline investigations in the earth sciences. For the first time scientists can view synoptic, repetitive scenes of the polar regions in four spectral bands. Ongoing experiments funded by NASA and conducted in the U.S. Geological Survey have demonstrated the feasibility of revising coastlines on maps of Antarc. tica, detected gross changes in the northern limits of the three largest ice shelves in the world, and led to the discovery of uncharted mountain ranges.
\end{abstract}

The launching of the first Earth Resources Technology Satellite (ERTS-1) and the successful operation of the onboard imaging systems introduced a whole new approach in monitoring and mapping the polar regions of the Earth. Anticipating the potential usefulness of ERTS imagery as source material for cartographic products, the U.S. Geological Survey proposed a series of experiments, which were approved and funded by the National Aeronautics and Space Administration (NASA). The approved proposal, "The Cartographic Applications of ERTS/RBV Imagery in Polar Regions" (designated SR.194), set in motion a number of investigations to determine the feasibility of expediting the ongoing Survey mapping operations that support the immediate and long-range goals of the U.S. Arctic and Antarctic research programs, which are administered and funded by the National Science Foundation. Other experiments in the proposal were designed to implement recommendations of the Committee on Polar Research (CPR) of the National Academy of Sciences-National Research Council (Committee on Polar Research, 1970) and the Working Group on Geodesy and Cartography of the Scientific Committee on Antarctic Research (SCAR) (Special Committee on Antarctic Research, 1959; Scientific Committee on Antarctic Research, 1967).

The information contained in this article was first given in May 1973 at the "Symposium on Approaches to Earth Survey Problems Through the Use of Space Techniques" during the meeting of the Committee on Space Research, Konstanz, Federal Republic of Germany, and in October 1973 during the fall convention of the American Society of Photogrammetry, Orlando, Fla.
The feasibility and economy of using ERTS imagery is being investigated for compiling maps of unmapped areas at scales of $1: 250,000$ to $1: 1,000,000$ on various formats, includingthe International Map of the World (IMW) series, for supplets menting planimetric information such as crevasse fields and glacier flow lines, for preparing photomaps at various scates, and for map revision... Other experiments will include idelineation and change detection of gross ice features; measuring seasonal variations of sea-ice boundaries, and mapping regional areas at $1: 10,000,000$ scale.

\section{STATUS OF ERTS-1}

The ERTS-1, launched July 23, 1972, by NASA, is in a circular, sun-synchronous, near-polar orbit at an altitude of $900 \mathrm{~km}$. It circles the Earth every $103 \mathrm{~min}(14 \mathrm{orbits} / \mathrm{d})$ and repeats a given orbital track every $18 \mathrm{~d}$. The science package includes three boresighted return-beam vidicon (RBV) cameras, each recording imagery in a discrete spectral band, and a multispectral scanner (MSS), which records in four spectral bands including near infrared (National Aeronautics and Space Administration, 1971).

The U.S. Geological Survey planned to use imagery from the RBV cameras for cartographic experiments because of its favorable geometric characteristics. However, shortly after the satellite achieved the desired orbit, the switches that activate the RBV cameras malfunctioned and one of the two onboard tape recorders became inoperable. It was therefore necessary to substitute MSS imagery as source material for the experiments. Although the geometric characteristics of MSS are not as desirable as those of RBV, the distortions of MSS are systematic and the imagery has good spatial and spectral resolution. (Perceptional and geometric image qualities of MSS and RBV were described by Colvocoresses and McEwen, 1973.)

Widely scattered MSS imagery has been received over both polar regions (figs. 1 and 2). Imagery beyond the range of the receiving stations in the United States and Canada was stored on a tape recorder and later transmitted on command to the receiving stations. Unfortunately, in early April 1973, sporadic noise degrading the images was interjected into the second recorder, which was turned off by NASA. 


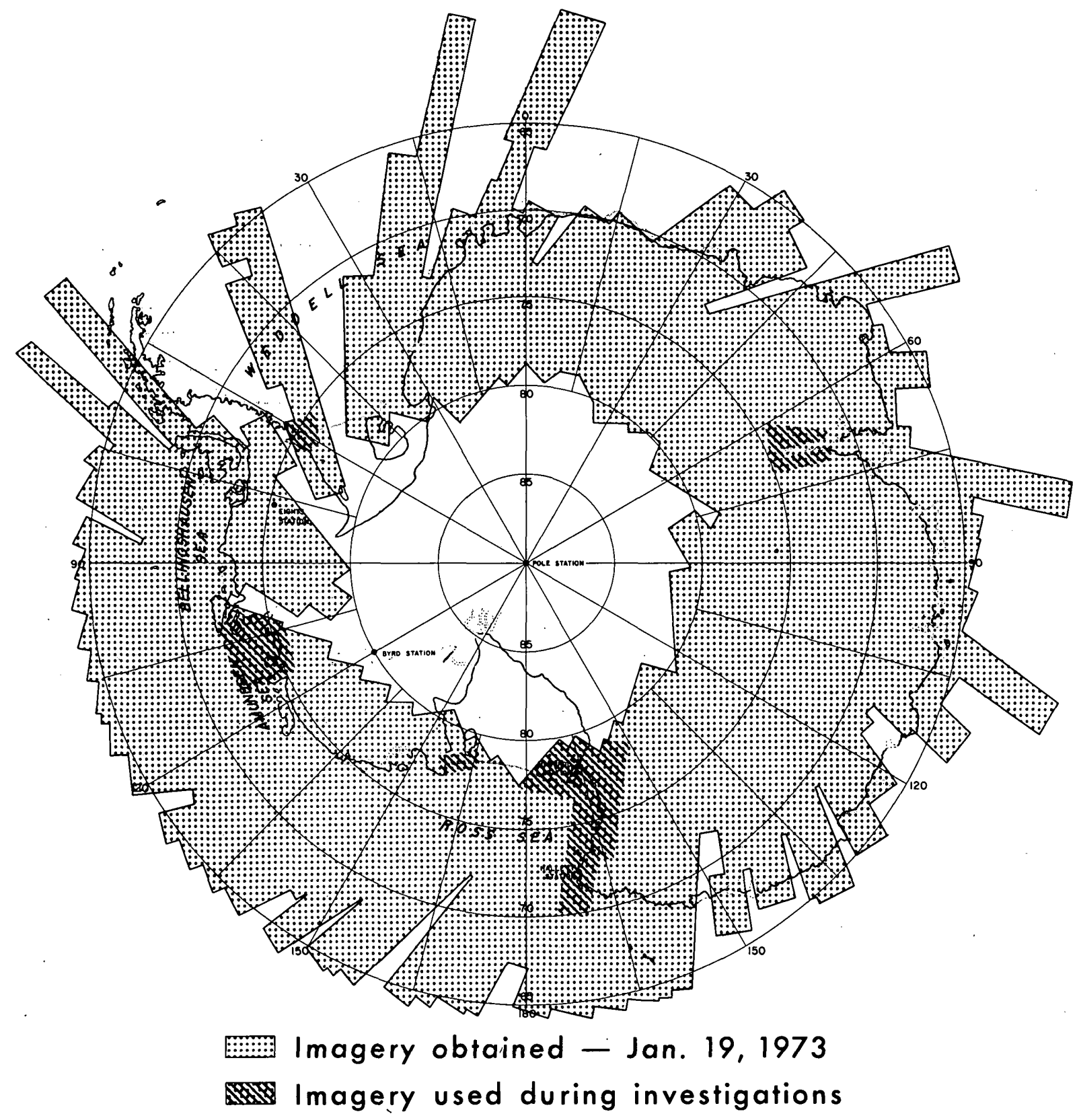

Figure 1.-ERTS-1 space imagery by multispectral scanner (MSS), Antarctica index.

The tape recorder functioned well until this event and actually had exceeded its designed 500 -h lifetime by about 10 percent. Without the recorder the ERTS-I satellite has very limited capability of providing any further imagery of the polar regions. No further imagery can be obtained of areas beyond the range of the few existing ground stations.

\section{IMAGERY REQUIREMENTS}

For the preparation of maps in support of the U.S. Antarctic research program, the United States has obtained aerial photography over an area of about $3,250,000 \mathrm{~km}^{2}$. This effort has cost many years and many millions of dollars. ERTS-1 now provides the capability of producing a single frame of imagery covering an area of about $34,000 \mathrm{~km}^{2}$ (185 by 185 $\mathrm{km})$. About 100 frames of ERTS imagery would cover the same area now covered by more than 100,000 aerial photographs. Thus we have seen the development of a system that produces highly useful and readily available synoptic imagery for meeting many of the mapping requirements of scientific investigations of the polar regions. 


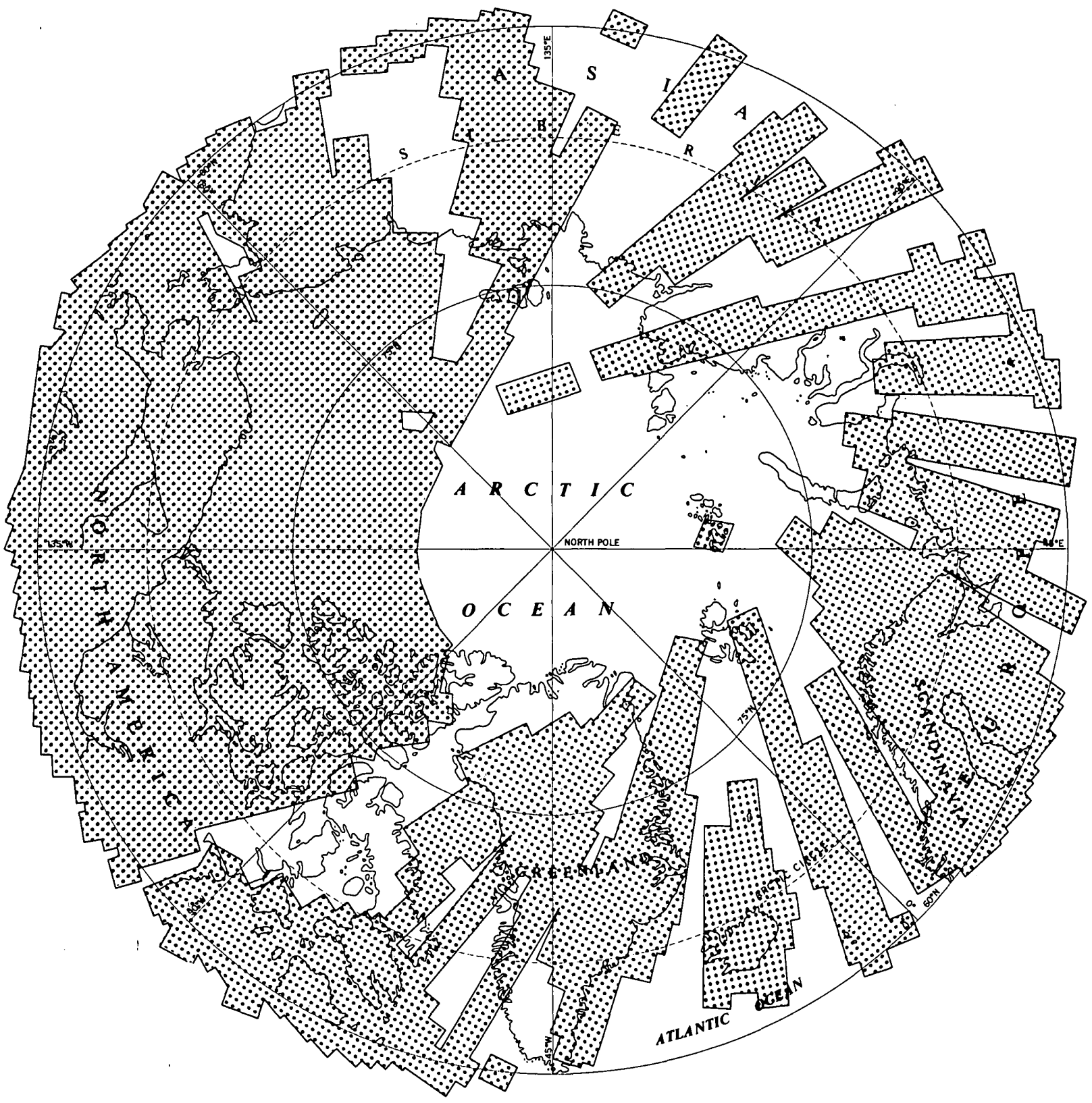

Figure 2.-ERTS-1 space imagery by multispectral scanner (MSS), Arctic index.

For use in the ERTS experiments, imagery with no more than 10-percent cloud cover was specified. Only about 5 percent of the imagery received so far met this specification (fig. 1). All available coverage is now being examined to find additional usable MSS imagery (50-percent cloud cover or less) of the polar regions.

NASA delivered the first MSS scenes of the Arctic region in October 1972 and of the Antarctic in December 1972. Of the four spectral bands, the near infrared (band 7) appears to offer the best data for cartographic applications and image interpretation in the polar regions.

\section{INVESTIGATIONS}

\section{Strip mosaic and change detection}

An important objective now is to compile 1:1,000,000-scale photoimage mosaics along the coastal areas of western Antarctica and, eventually, along the coastal areas of all Antarctica. These imagery products will enable the U.S. Geological Survey to build a historical record which, when compared against existing maps and sequential ERTS coverage, will show changes in size, shape, and position of features such as ice shelves, glaciers, and ice tongues (fig. 3). 


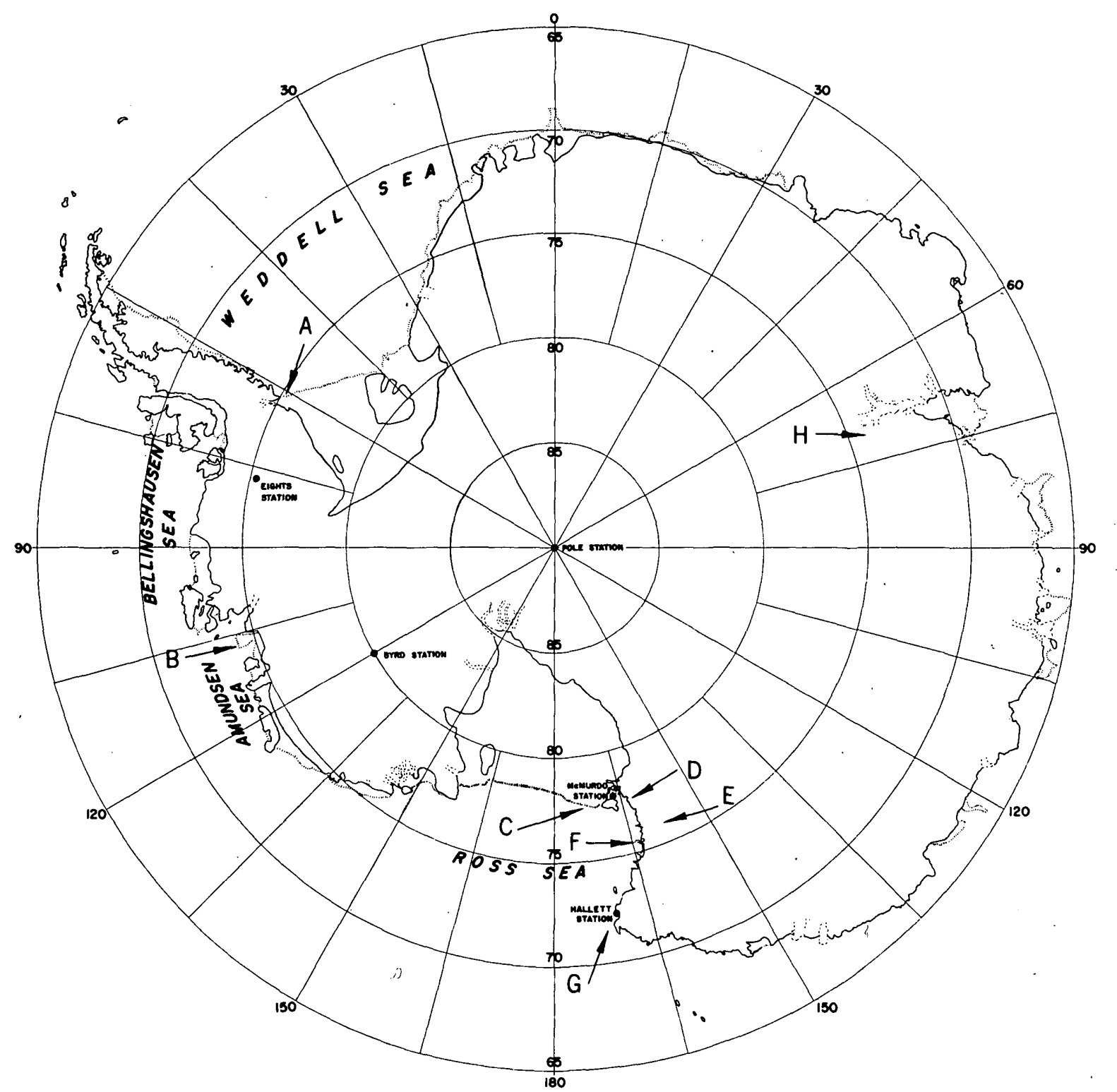

Figure 3.-Locations of significant changes evident from ERTS imagery (Dec. 1972-Feb. 1973).
A. Ronne Ice Front
D. McMurdo
G. Hallett (fast ice)
B. Thwaites Ice Tongue
E. New features on IMW
H. Lambert Glacier
C. Ross Ice Shelf
F. Drygalski Ice Tongue
(new features)

A strip photomosaic, comprising parts of seven ERTS-1 images, was compiled at 1:1,000,000 scale along the Victoria Land coast of Antarctica between Cape Adare and Harbord Glacier. This mosaic, covering an area of 185 by $644 \mathrm{~km}$, depicts 45 glaciers and ice tongues, numerous ice shelves, and the northern extent of the Transantarctic Mountains. This experiment is a pilot effort, and other 1:1,000,000-scale photoimage mosaics along the coastal areas of West Antarctica between the Ross Ice Shelf north and westward to long. $180^{\circ}$ E. will be compiled under this proposal.
Glaciers, ice tongues, and ice shelves were clearly identifiable on the 1:1,000,000-scale ERTS imagery. This pilot project indicated that the imagery was of sufficient resolution to be used as a source for photoimage revision and for glaciological change detection.

Further investigations proved that ERTS imagery can be used effectively for planimetric revision of small-scale maps, and this technique is being applied to the six 1:250,000-scale topographic maps that fall in the area of the Victoria Land strip mosaic. 
A detailed cartographic analysis has not been completed over the entire area of the mosaic, but the coastline was carefully compared with existing maps, and several major changes in coastal features were found. The comparison showed that the new satellite imagery can greatly facilitate meaningful revision of the existing maps (figs. 4 and 5).

Because the 1:250,000-scale source maps were compiled from multiyear aerial photography, it would be erroneous to use the map publication date as a benchmark for determining ice movement. Accordingly, in our analysis, it was necessary to determine the date of aerial photography used as source for each feature on the existing map. In the future, scientists need only refer to the taking date of the ERTS imagery.

\section{Map revision}

Figure 6 illustrates the application of ERTS imagery for evaluating and revising published maps. The graphic on the bottom is a composite of two 1:500,000-scale sketch maps compiled from conventional photographs taken during the

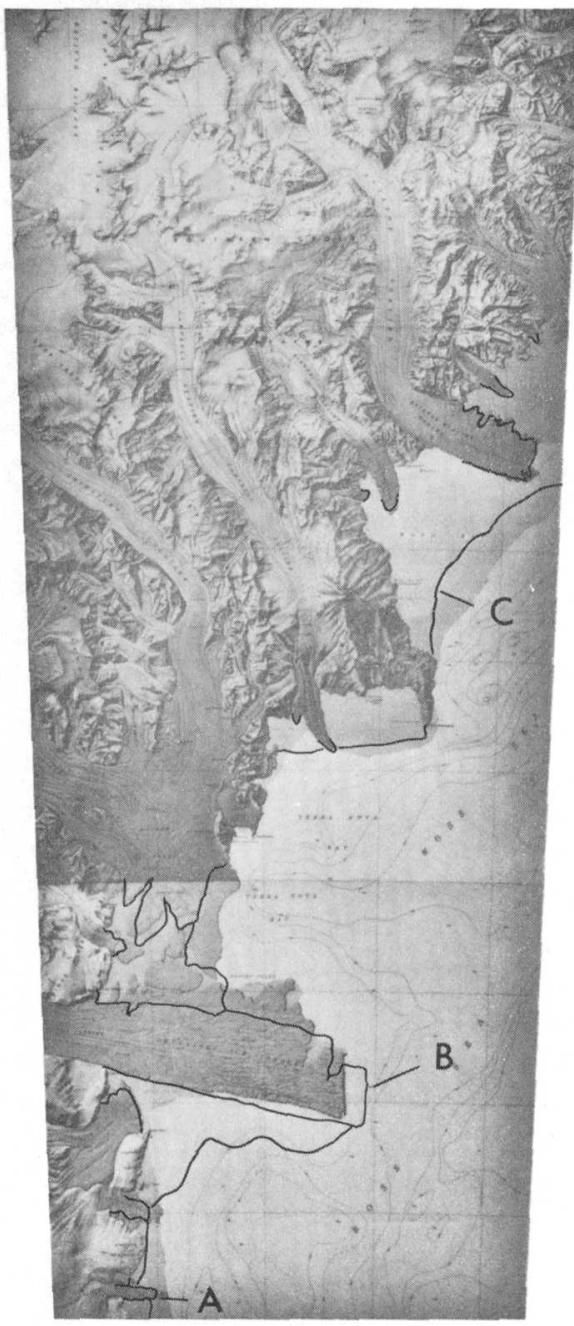

austral summer of 1965-66. The graphic on the top is a mosaic of parts of seven scenes of MSS bulk imagery. Area coverage is about $117,000 \mathrm{~km}^{2}$. The two triangles represent geodetic positions used to fit the imagery mosaic to the map base. The ERTS imagery greatly improves the absolute and relative positioning of shoreline configurations, ice tongues, and other map features. Because of the limited amount of control and the large number of conventional photographs used to compile the sketch maps, it was not possible to maintain scale and position throughout the map compilation, especially in areas devoid of readily identifiable features that make good pass points. A single ERTS scene covers the same area as 1,320 photographs at a 1:40,000 scale. Comparing the two parts of figure 6 , note the change in the configuration of the coast, as indicated by 1,3 , and 4 , and in the position of Burke Island, as indicated by 2 . Also note the change in size and position of the Thwaites Iceberg Tongue, 5. Area has increased from 44,200 $\mathrm{km}^{2}$ (map) to $71,500 \mathrm{~km}^{2}$ (image), and the position has shifted about $8 \mathrm{~km}$.

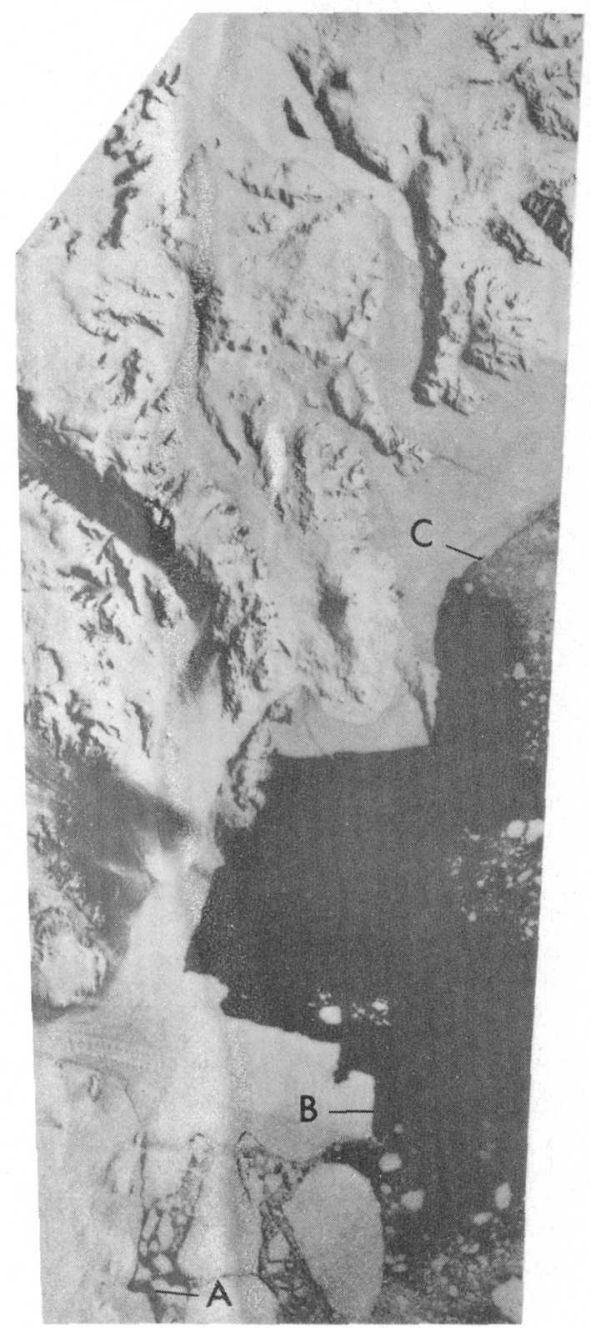

Figure 4.-Victoria Land coast area. Harbord Glacier (A), Drygalski Ice Tongue (B), and fast ice (C). Left, three 1:250,000-scale U.S. Geological Survey topographic maps compiled from source data, 1955-64. Annotated revisions based on ERTS-1 imagery. Right, ERTS photoimagery mosaic showing significant changes. 

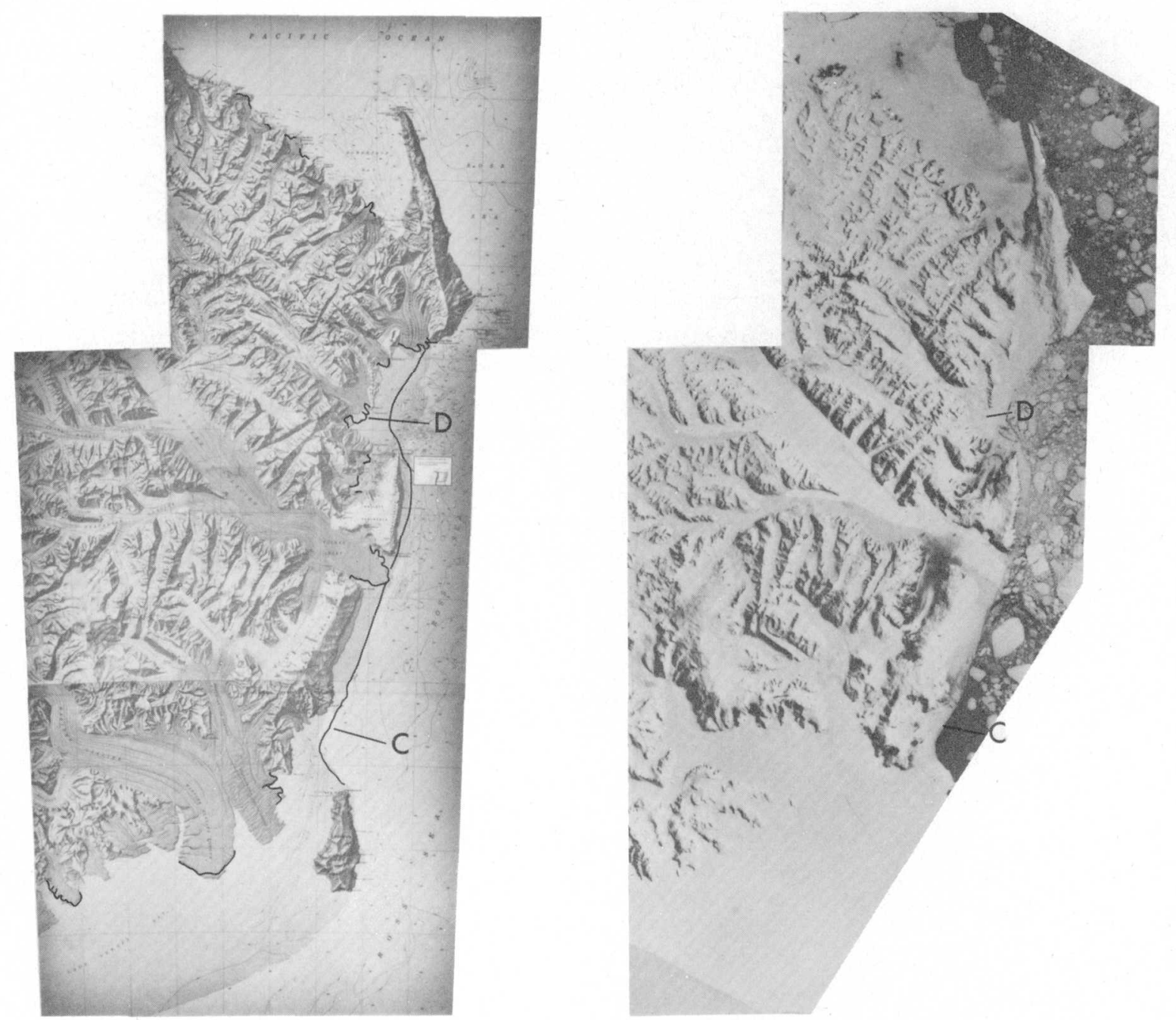

Figure 5.-Victoria Land coast area. Left, three 1:250,000-scale U.S. Geological Survey topographic maps compiled from source data, 1961-64. Annotated revisions based on ERTS-1 imagery. Right, ERTS photoimagery mosaic showing significant changes: Boundary of fast ice and bay ice at $\mathrm{C}$ has changed, and the shapes of Honeycomb and Ironside Glaciers at $D$ have changed and their combined tongue has advanced about $3.2 \mathrm{~km}$.

\section{Small-scale mapping}

The main immediate application of ERTS-1 imagery in the polar regions, particularly in Antarctica, is the compiling of 1:1,000,000-scale maps and photoimage mosaics. The need for million-scale coverage of Antarctica has been recognized by several organizations, including the Scientific Committee on Antarctic Research (1967) and the Committee on Polar Research (1970).

Because of the virtual impossibility of taking photographs with ordinary aircraft at altitudes high enough for efficient million-scale mapping, efforts before the launching of ERTS-1 were directed primarily toward mapping the coastal and mountain areas at 1:250,000 scale. ERTS imagery, however, meets the needs for million-scale photomapping, which is expected to prove beneficial to the international scientific community. To cover an IMW map area, cartographers will only have to assemble 15 to 20 ERTS scenes rather than 12,000 conventional photographs. Production cost will decrease as production rate increases. The user will have at his disposal a visual representation of vast areas that have never been mapped. Moreover, he will not have to wait years before the image maps are available.

Comparisons carried out on the U.S. Geological Surveycompiled McMurdo Sound region, IMW sheet ST 57-60 (fig. 7), and on the Australian-compiled IMW sheet SS 40-42 (fig. 8) clearly demonstrate the application. Revisions and additions to the two sheets are readily apparent. The most obvious changes are the large block of new and unmapped geographical features revealed by the ERTS imagery. Noteworthy revisions include the repositioning of the Ross Ice Shelf Front (about $6.4 \mathrm{~km} \mathrm{north})$ and Franklin Island (7.2 km south). The 

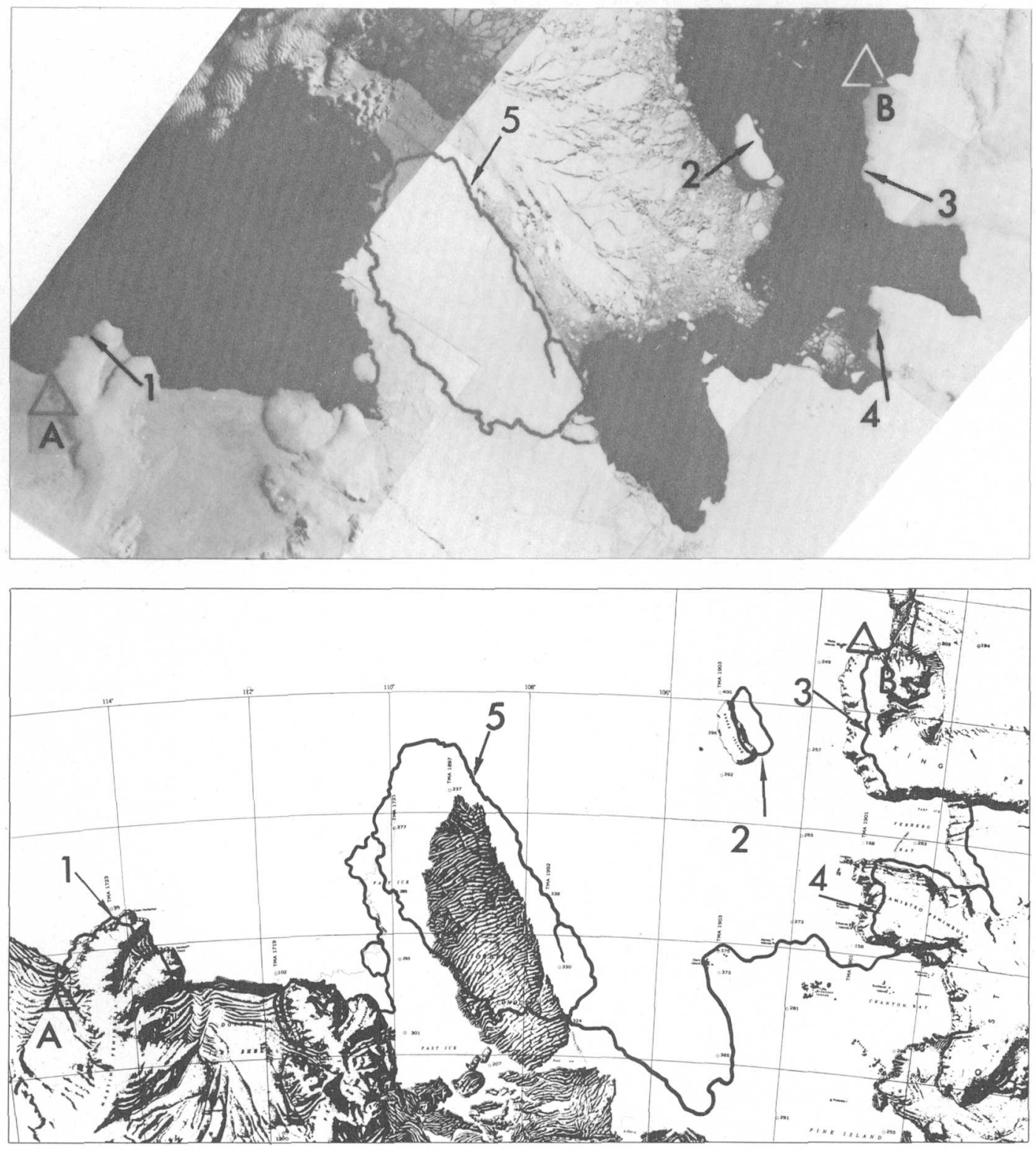

Figure 6.- Thwaites Iceberg Tongue area. Annotated mosaic of ERTS-1 imagery (top) and corresponding sketch map (bottom). Annotations show significant changes in the coastline $(1,3$, and 4) in the position of Burke Island (2), and in the size and position of Thwaites Iceberg Tongue (5) that can be detected by ERTS-1 imagery. A and B are geodetic control points.

position of Franklin Island has been in contention for many years and has been continually reported in error by U.S. ships.

Reference to the IMW 1:1,000,000-scale index of Antarctica (fig. 9) and the space-imagery index (fig. 1) indicates the value of ERTS-1 imagery to the IMW mapping program. Because of the $99^{\circ}$ orbital inclination (ascending node) of the satellite, imagery cannot be obtained between lat $82^{\circ} \mathrm{S}$. and the pole. Accordingly, if all the available imagery is of satisfactory quality, which has yet to be determined, 71 maps can be compiled.

\section{SCIENTIFIC APPLICATION}

Comparison of ERTS scene 1154-19322, dated December 24,1972 , with the published Ross Island 1:250,000-scale map disclosed a unique change in the Erebus Glacier Tongue (fig. 10). Further examination of photographs and historical maps indicated that the present position of the tongue is about the same as it was in 1910 (Debenham, 1923) and that the tongue has advanced about $9.6 \mathrm{~km}$ since 1947 and $4.8 \mathrm{~km}$ since 1962 . A lateral shift or curving of the leading front toward the mainland seems to have occurred since 1970. Sources are not 

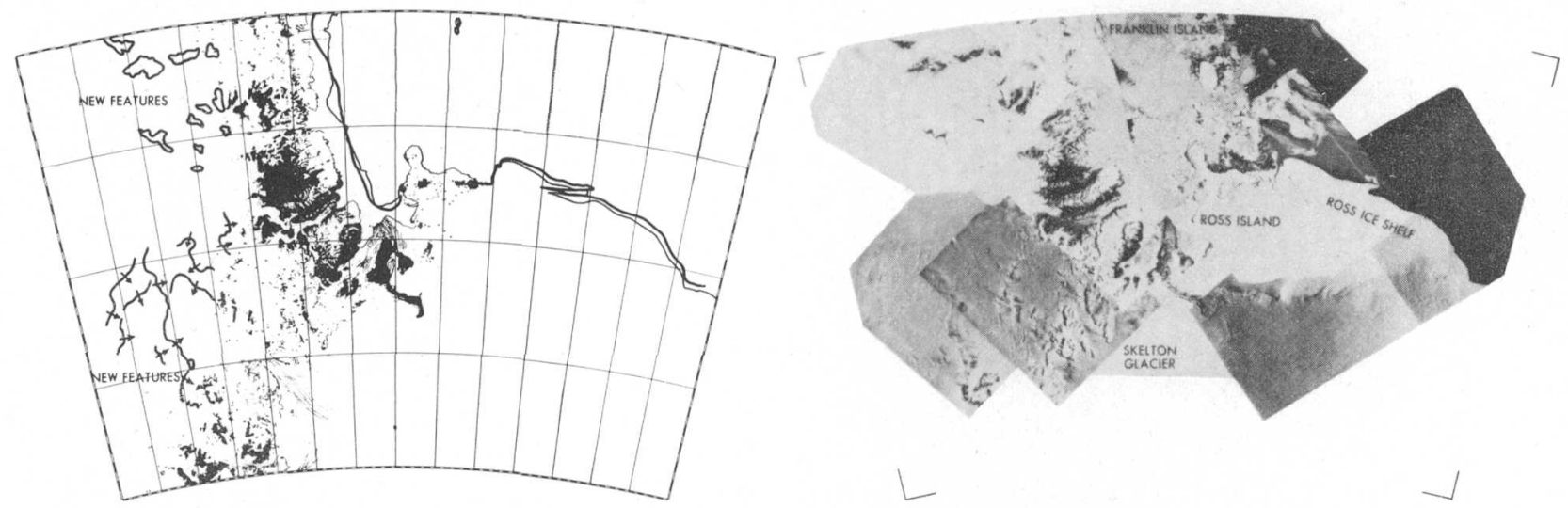

Figure 7.-McMurdo 1:1,000,000-scale map (IMW series) and ERTS imagery. With the aid of the ERTS imagery mosaic, newly discovered mountains, land features, and coastal changes will be depicted on the new USGS 1:1,000,000-scale map.

AUSTRALIAN 1:1,000,000

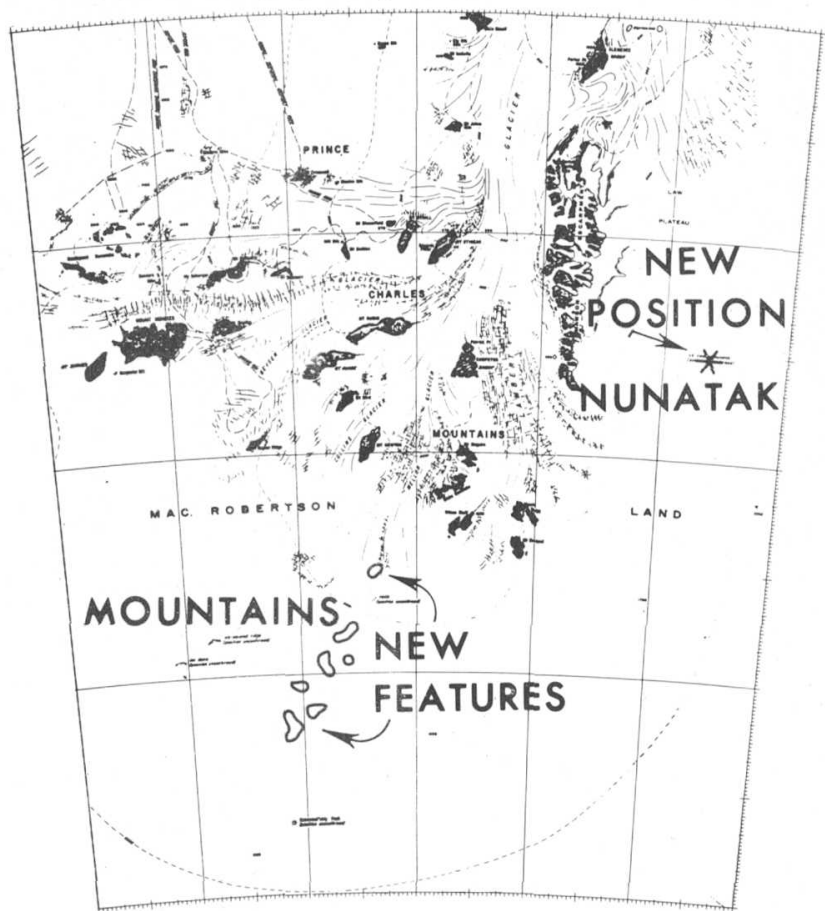

ERTS-1 IMAGERY LAMBERT GLACIER

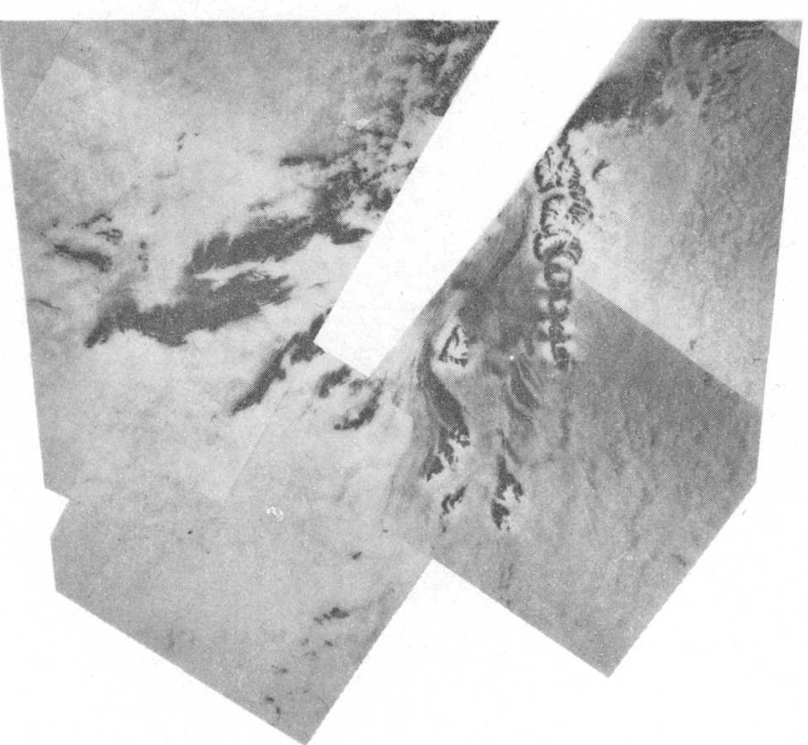

Figure 8.-Australian 1:1,000,000-scale map (IMW series) and ERTS imagery. With the aid of ERTS imagery, it is possible to analyze and evaluate existing source maps. The imagery reveals new mountains and other significant features which can be added to the Australian 1:1,000,000-scale map.

adequate to determine whether the moveinent occurred gradually or over a very short period. Some evidence does seem to indicate that the tongue may have gone through a surging period. Perhaps it has completed a growth cycle and will again break off as it did in 1911. If ground investigation proves it to be a surging glacier, it will be the first one found in Antarctica and therefore of keen interest to glaciologists.
Further indication that ERTS imagery is useful for detecting glaciological changes is given in figure 11. ERTS scene 1212-11183, dated Feb. 20, 1973, was compared with the published 1:500,000-scale sketch map of Ellsworth Land and Palmer Land and with aerial photographs to determine that the Ronne Ice Shelf has advanced about $16 \mathrm{~km}$ since January 1966. 


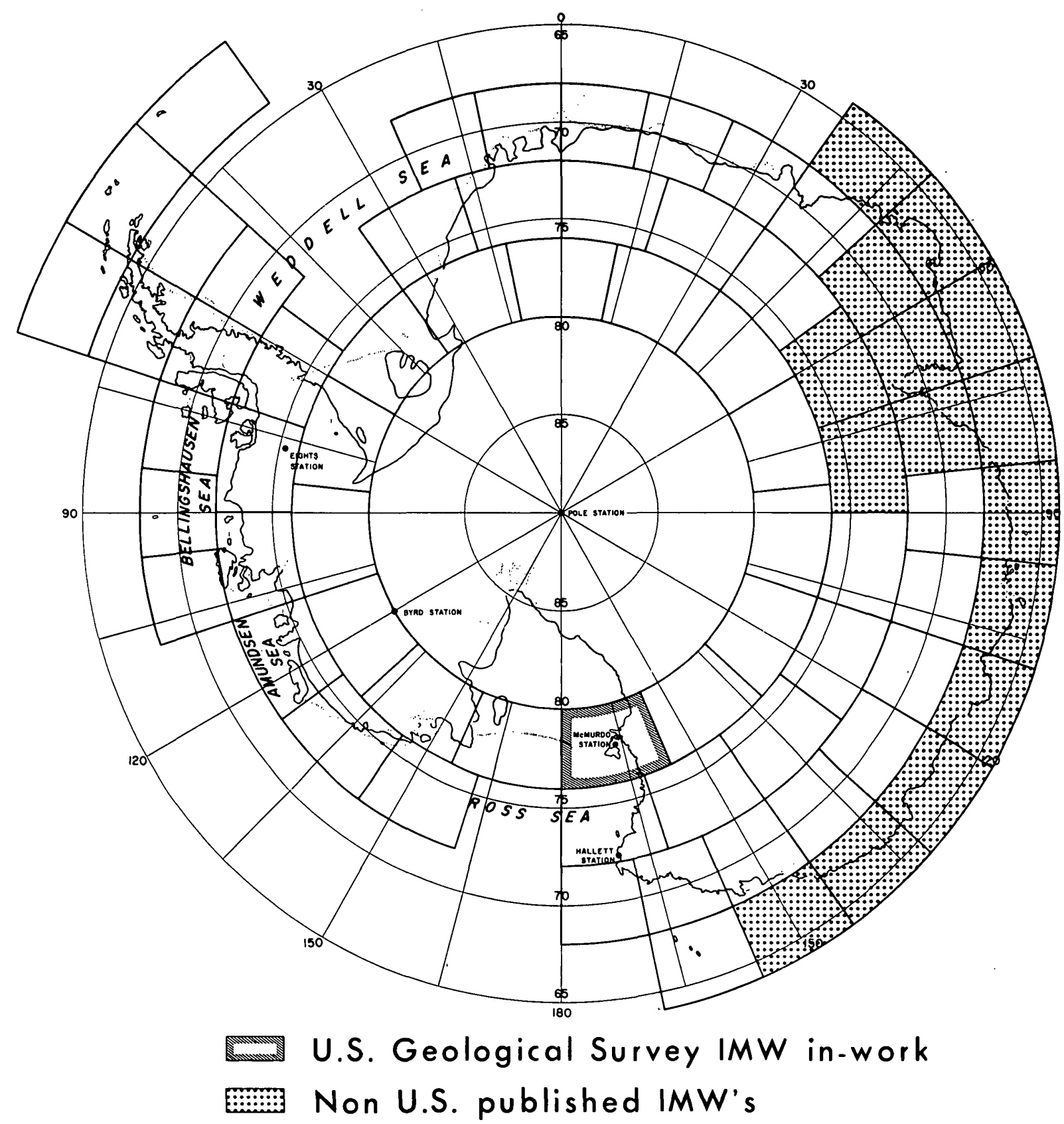

Figure 9.-Antarctica IMW 1:1,000,000-scale map.

\section{FUTURE PLANS}

In addition to experiments discussed in this article, plans include investigating the use of MSS imagery to:

1. Compile a small-scale $(1: 10,000,000)$ photomap of the entire continent of Antarctica.

2. Compile thematic maps of sea-ice conditions.

3. Begin an analysis of the variations of the sea-ice boundary and rate of deformation of pack ice.

4. Compile physical maps of the Arctic region.
5. Compile 1:1,000,000-scale photoimage mosaics of Alaska as references for evaluating ecological effects of North Slope and pipeline development and for revision of published maps.

With the ERTS imagery as a current guide, Doppler satellite-tracking equipment will be used to establish geodetic control for Antarctic mapping. Survey teams will be sent to the field during the Antarctic austral season to establish geodetic positions $(x, y$, and $z)$ on preselected points identifiable on ERTS scenes. 


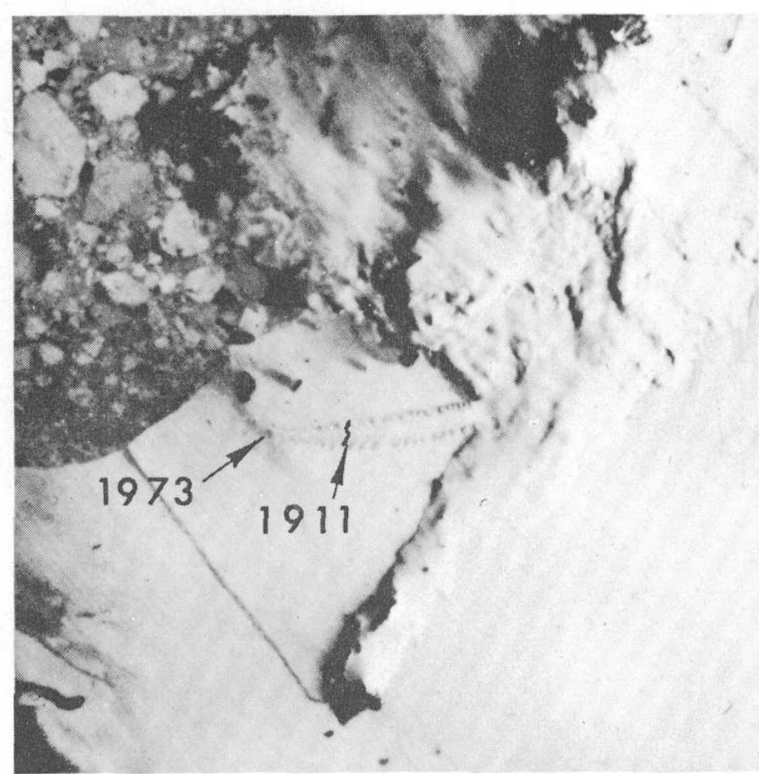

Figure 10.-ERTS imagery of Erebus Ice Tongue. Analysis of ERTS images and library sources determined that the Erebus Glacier Tongue has advance $9.6 \mathrm{~km}$ since 1947. Place where the tongue broke off in 1911 is annotated.

\section{CONCLUSION}

Though we have had only a few months of experience in using ERTS imagery for investigations of the polar regions, we are sure that it can form the basis of a quality map product that will meet most users' needs. We are also sure that ERTS imagery can be used as source for revision of published small-scale and medium-scale maps of coastal areas in the polar regions.

The U.S. Geological Survey is responsible for maintaining the United States SCAR Library, and distributing copies of all cartographic products of Antarctica compiled in the United States to the 11 other Antarctic Treaty nations. We therefore already have an established system which can be expanded to distribute ERTS imagery on request to member nations of SCAR.

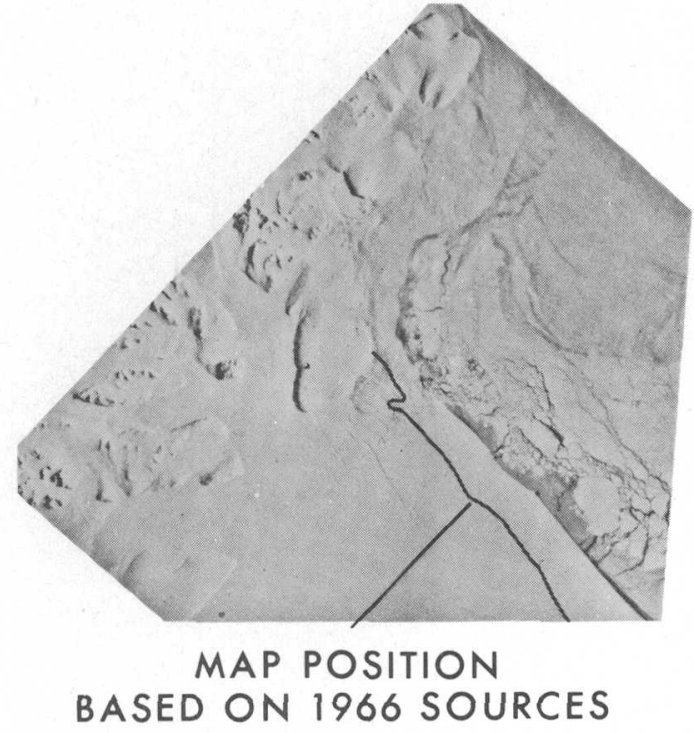

Figure 11.-ERTS imagery of Ronne Ice Shelf. The edge of the shelf has advanced about $16 \mathrm{~km}$ since 1966.

\section{REFERENCES CITED}

Colvocoresses, A. P., and McEwen, R. B., 1973, EROS cartographic progress: Photogramm. Eng., v. 39, no. 12, p. 1503-1509.

Committee on Polar Research, 1970, Polar geodesy and cartography, in Polar research-A survey: Natl. Research Council, Natl. Acad. Sci., chap. 5 , p. $103-138$.

Debenham, Frank, 1923, Map of Ross Island-West Coast, in Report on the maps and surveys-British (Terra Nova) Antarctic Expedition 1910-13: London, Harrison and Sons, Ltd., map 5, scale $1: 100,000$.

National Aeronautics and Space Administration, 1971, ERTS Payload, in Data Users Handbook: Greenbelt, Md., NASA Goddard Space Flight Center, App. A, p. A1-A19.

Scientific Committee on Antarctic Research, 1967, SCAR bulletin No. 26, May 1967-Report on geodetic and cartographic activities, 1960-1965: Polar Rec., v. 13, no. 86, p. 703-737.

Special Committee on Antarctic Research, 1959, SCAR bulletin No. 3, September 1959: Polar Rec., v. 9, no. 63, p. 589-608. 


\section{YACHATS BASALT-AN UPPER EOCENE DIFFERENTIATED VOLCANIC SEQUENCE IN THE OREGON COAST RANGE}

By PARKE D. SNAVELY, JR. and NORMAN S. MacLEOD, Menlo Park, Calif.

\begin{abstract}
The name Yachats Basalt is proposed for a sequence of largely subacrial basalt flows and breccias and associated dikes of late Eocene age that are exposed along the central Oregon coast. These volcanic rocks, which have a maximum thickness of $750 \mathrm{~m}$, are underlain by marine siltstone of late Eocene age and overlain by marine siltstone and basaltic sandstone, also of late Eocene age. The siltstone contains a foraminiferal fauna indicative of a moderately deepwater marine environment, indicating that local uplift preceded the extrusion of the flows and local subsidence followed. The Yachats Basalt varies widely in composition. Although the bulk of the extrusive rocks and dikes are basalt, some grade in composition to basaltic andesite and andesite; a few dikes are rhyodacitic. Most of the rocks are porphyritic with phenocrysts of labradorite and less commonly augite and olivine. Typical flow rock contains 50 percent $\mathrm{SiO}_{2}$ and are characterized by high alumina, alkali, titania, and phosphate content. The wide range in composition and porphyritic character of the Yachats Basalt and the abundance of multiple dikes suggest that the magma that produced these rocks was differentiated in the upper crust before extrusion. The Yachats Basalt, and correlative upper Eocene volcanic rocks in western Oregon and Washington, lie along a generally north-trending belt. The predominance of normal faulting in western Oregon and Washington and on the adjacent continental shelf during post mid-late Eocene time suggests that the volcanics were extruded along a zone of tensional rifting. They do not appear to be related to conventional plate models for continental margins that are characterized by deep trenches flanked by island arcs.
\end{abstract}

Upper Eocene basalt flows, largely of subaerial origin, form stratigraphically important units in the more than $6,000 \mathrm{~m}$ of Tertiary sedimentary and volcanic rocks that crop out in the Oregon Coast Range. One such sequence of basalt flows, breccias, and associated sedimentary rocks that forms the precipitous and scenic sea cliffs along the coast between the towns of Yachats and Florence is described and herein named the Yachats (pronounced yah-hots) Basalt. The type section is designated as the outcrops along the Yachats River extending northwestward from the base of the sequence near the center of sec. 31, T. 14 S., R. 11 W., to the top of the sequence in the low sea cliffs at Yachats in the SE $1 / 4$ sec. 22, T. 14 S., R. $12 \mathrm{~W}$.

. .. (See $A-B$ in fig. 1). The excellent exposures in sea cliffs and on the wave-cut platform from the town of Yachats $15 \mathrm{~km}$ south to Big Creek and at Heceta Head are designated reference sections.
The volcanic rocks that make up the Yachats Basalt were first referred to by Washburne $(1914$, p. 95) who called attention to a large mass of igneous rocks at Cape Perpetua which he noted were overlain by coarse-grained sandstone and conglomerate at the town of Yachats. He incorrectly assigned a Miocene age to the upper Eocene sedimentary rocks because Arnold (1906, p. 119-120) earlier had tentatively assigned a lower Pliocene age to fossils that Washburne collected from these rocks. Callaghan (1927) described the sequence in more detail and referred to the volcanic rocks as the "Tenmile basalt." In their mapping of the Waldport quadrangle, Vokes and others (1949) indicated that basalt flows and breccia were interbedded with marine siltstone and sandstone of the late Eocene and Oligocene Toledo Formation; they referred to these extrusive rocks as "volcanic rocks of late Eocene and Oligocene age." Baldwin (1956) on his map of the Heceta Head quadrangle informally referred to the Yachats Basalt as "Volcanic rocks" and assigned them a late Eocene age. In recent publications the Yachats Basalt has been informally designated as "alkalic basalt" (Snavely and Wagner, 1964), the basalt member of the upper Eocene Nestucca. Formation (Snavely and others, 1969), and basalt of Yachats (Snavely and others, 1972b, and MacLeod and Snavely, 1973).

\section{GEOLOGIC SETTING}

Three major sequences of basaltic volcanic rocks are interbedded in the more than $6,000 \mathrm{~m}$ of Eocene to Miocene marine sedimentary rocks in the central part of the Oregon Coast Range. The oldest volcanic unit, the Siletz River Volcanics (Snavely and others, 1968), consists of tholeiitic pillow lavas and breccia of early and middle Eocene age that are interpreted as representing oceanic crust and volcanic islands associated with it. The Yachats Basalt, of latest Eocene age, forms the middle unit. The youngest lava flows and breccias are the Depoe Bay and Cape Foulweather Basalts (Snavely and others, 1973) of middle Miocene age that crop out along the coast near Newport, $55 \mathrm{~km}$ north of the Yachats Basalt. 

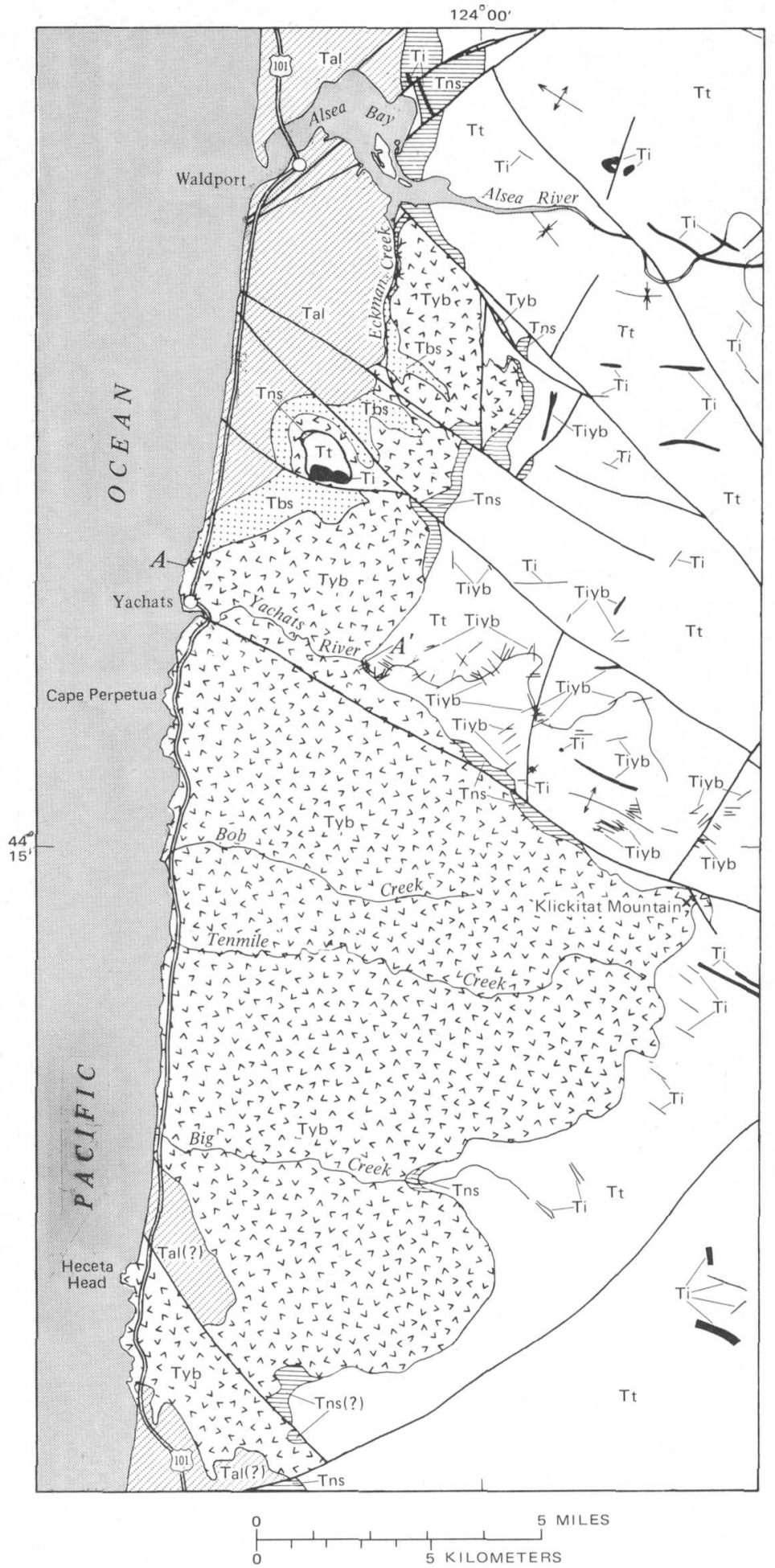

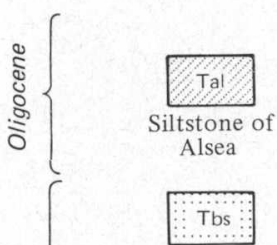

Unnamed basaltic sandstone
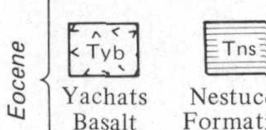

ETns

Nestucca

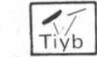

Intrusive

rocks re-

Yachats

Basalt
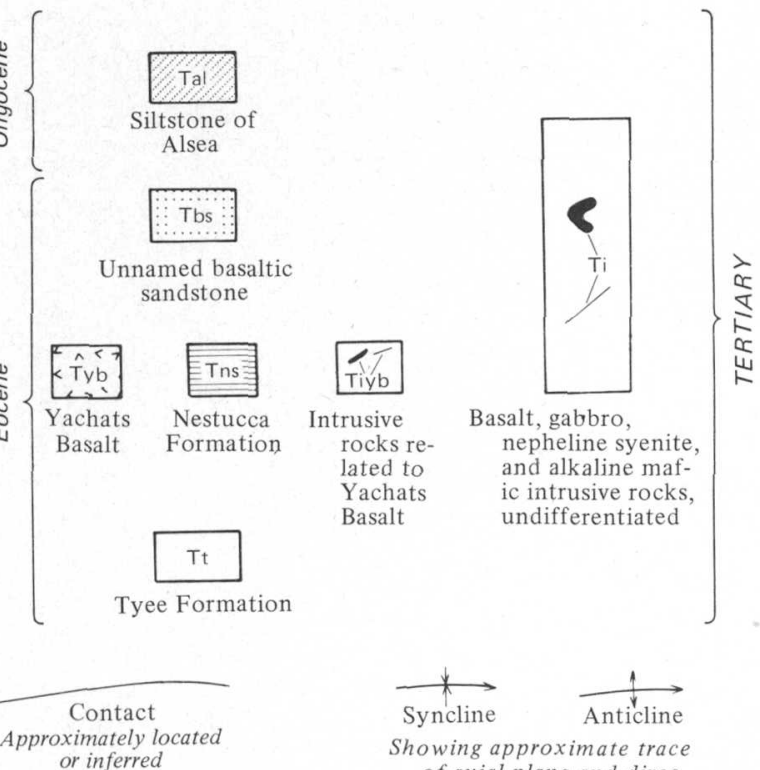

Showing approximate trace of axial plane and direction of plunge

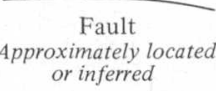

$A-A^{\prime}$, type section of Yachats Basalt

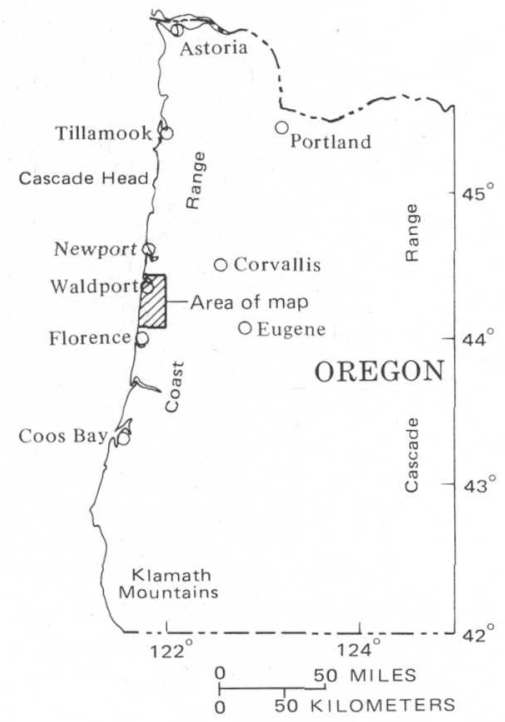

Figure 1.-Bedrock geologic map showing distribution of the Yachats Basalt in coastal western Oregon. Geology south of lat $44^{\circ} 15^{\prime}$ modified from Baldwin (1956).

The Yachats Basalt forms a lenticular pile of chiefly subaerial flows and flow breccia with lesser amounts of submarine pillow lava, breccia and tuff, and basaltic conglom- erate and sandstone. This volcanic sequence is stratigraphically equivalent to the upper part of the upper Eocene Nestucca Formation (Snavely and Vokes, 1949; Snavely and others, 
$1972 \mathrm{~b}, \mathrm{c}$ ), which consists of thin- to medium-bedded marine tuffaccous siltstone and fine-grained sandstone. A regional unconformity separates the Yachats Basalt and the Nestucca Formation from older units in the central Oregon Coast Range. Both formations overlap the Yamhill Formation of early late Eocene age to rest on the middle Eocene Tyee Formation (fig. 1). Furthermore, the Yachats Basalt throughout much of its outcrop area overlaps the Nestucca Formation and rests on the Tyee Formation.

Subaerial flows at the base of the Yachats Basalt at several localities overlie siltstone of the Nestucca Formation that contains foraminiferal assemblages indicating a moderately deepwater depositional environment (W. W. Rau, written commun., 1970). These stratigraphic relations suggest that local uplift preceded extrusion of the basalt. Basinward, away from the area of uplift, however, the absence of any hiatus within the Nestucca Formation indicates that sedimentation there was continuous. At Cascade Head, $85 \mathrm{~km}$ north of the town of Yachats, a sequence of basalt flows of late Eocene age has a similar stratigraphic relation to the Nestucca Formation. There, thin-bedded siltstone and fine-grained sandstone, which contain a moderately deepwater foraminiferal fauna, are separated from an overlying thick sequence of subaerial flows by only 30 to $50 \mathrm{~m}$ of subaqueous basalt breccia.

Eruption of the Yachats Basalt was followed closely by a period of erosion and deposition of an unnamed continental and marine unit of basaltic congiomerate and sandstone up to $100 \mathrm{~m}$ thick in latest Eocene time. This basaltic sandstone unit thins rapidly northward away from the area where the Yachats Basalt attained its greatest thickness and elevation and is not present above the volcanic rocks at the northern limit of outcrop (fig. 1).

Rapid local down warping closely followed the deposition of the unnamed basaltic sandstone unit for it is overlain by the siltstone of Alsea, a moderately deepwater tuffaceous siltstone of Oligocene age. In the northernmost outcrop area of the Yachats Basalt, however, where the basaltic sandstone unit is absent, the flows and breccia are overlain by thin-bedded tuffaceous siltstone and sandstone of the Nestucca Formation. These Nestucca strata contain a foraminiferal fauna indicative of a moderately deepwater depositional environment (W. W. Rau, oral commun., 1970).

\section{DISTRIBUTION AND PHYSICAL CHARACTER}

The Yachats Basalt is a west- to northwest-dipping sequence of lava flows and breccia that crops out from Alsea Bay southward about $35 \mathrm{~km}$ to near Heceta Head on the coast (fig. 1). The widest outcrop belt is in the vicinity of Tenmile Creek where the volcanic rocks extend from the coast about $15 \mathrm{~km}$ eastward to Klickitat Mountain. The Yachats Basalt may have extended well into the central part of the Coast Range because numerous dikes similar to those within the flow sequence are present in the Tyee Formation east of the present outcrop area of the flows. A westward extension of the basalts at least $5 \mathrm{~km}$ beyond the coast is indicated by high-frequency magnetic anomalies on the inner continental shelf (U.S. Geological Survey, 1969).

The thickness of the Yachats Basalt is difficult to determine because the lava was erupted onto an irregular land surface and the flows are well exposed only along the coast, in river outcrops, and on a few logging roads. Individual flows have irregular lower and upper surfaces, and thus attitudes are difficult to obtain and some of the dips shown by the flows are probably primary. Where the sequence is well exposed along the coast, it is cut by numerous generally northwesttrending faults, many with an undetermined amount of displacement. The presence of northwest-trending linear valleys inland suggests that some of these faults may extend across the entire area of outcrop and either repeat or cut out section. On the basis of attitudes of the marine sediments that overlie and underlie the flows and sparse structural data within the flow sequence, we estimate the Yachats Basalt to have a maximum thickness of about $750 \mathrm{~m}$ in the vicinity of Tenmile Creek. North and south of this area the flow sequence is thinner. In the northern part of the map area, along Eckman Creek, the sequence thins to less than $150 \mathrm{~m}$. The flow sequence apparently did not extend much farther north because no volcanic rocks are found on the north side of Alsea Bay where marine siltstone and sandstone of the same age crop out (fig. 1). South of Heceta Head the flow sequence also thins and contains interbedded marine sedimentary rocks. The basaltic sandstone unit that overlies the Yachats Basalt in places appears to fill canyons cut in the basalt, suggesting that the original thickness of the basalt was modified by erosion prior to deposition of the sandstone.

The Yachats Basalt consists chiefly of subaerial basalt flows. The basalt is dark to medium gray and characteristically porphyritic. Tabular phenocrysts of plagioclase are easily recognized in most hand samples and make up 10 to 15 percent of the rock, although some are aphyric and others are even more porphyritic. Individual flows vary in thickness; most are 3 to $8 \mathrm{~m}$ thick, but some are as much as $20 \mathrm{~m}$. The lower half of typical flow units is composed of dense basalt that lies on a rubbly breccia base. Rude jointing that produces roughly rectangular blocks and, less commonly, columnar jointing (fig. 2) characterizes flows of basaltic composition. Curved, platy joints that parallel flow surfaces and produce disk-shaped blocks are abundant in more siliceous (andesitic) flows. The upper half of typical flow units is formed of scoriaceous breccia that is oxidized to reddish and purplish hues. Some blocks within the breccia have ropy surfaces, others are rough and jagged. Abundant vesicles and amygdules occur in blocks in breccia and are also common in the lower massive parts of many flows. Brick-red oxidized tuff and crystal tuff a few centimeters to several meters thick occur between some flow units. Aerodynamically shaped bombs were noted in some tuff and breccia. 


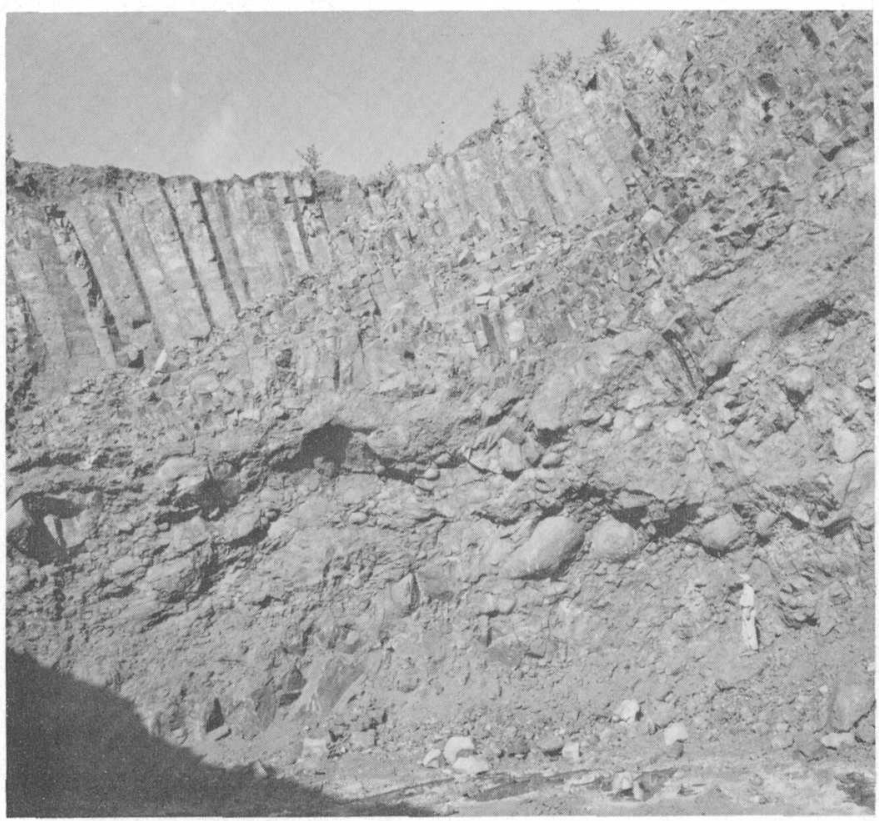

Figure 2.-Boulder and cobble conglomerate interbed in Yachats Basalt overlain by columnar-jointed basalt flow at quarry on Eckman Creek $5 \mathrm{~km}$ southeast of Waldport.

A sequence of thin flows that is cut by small dikes on a headland near Bob Creek appears to be a local vent. The flows are less than $1 / 4 \mathrm{~m}$ to $1 \frac{1}{2} \mathrm{~m}$ thick, are very vesicular, and have a scoriaceous upper part. They are cut by several dikes that appear to have fed some later flows. Other vent areas are indicated by irregular piles of welded spatter and near-vent breccia that contains red oxidized volcanic bombs as much as $30 \mathrm{~cm}$ across.

Although the bulk of the Yachats Basalt is composed of subaerial flows, in places the lowermost part of the sequence contains interbedded submarine breccia, pillow basalt, and basaltic sedimentary rocks. The description of these units is based largely on the exposures near Heceta Head where more than $200 \mathrm{~m}$ of complexly interbedded rudely bedded tuff breccia, pillow breccia, thin flows, basaltic sandstone, and conglomerate are well exposed in the sea cliffs.

Several thick units of pillow basalt are well exposed at the base of the sea cliff $3 \mathrm{~km}$ south of Heceta Head. Here ellipsoidal close-packed pillows of porphyritic basalt about 1 $\mathrm{m}$ long are interbedded with water-laid lapilli tuff. At Heceta Head broken pillow breccia and isolated pillow breccia are interbedded with basaltic sandstone and tuff breccia. On the north side of Heceta Head a 30-m-thick unit of pillow lava and pillow breccia that contains many inclusions of sedimentary rocks grades upward into flow breccia. Here also a 5-m-thick flow of massive basalt grades laterally into large pillows and pillow breccia.

Conglomerate beds as much as $10 \mathrm{~m}$ thick consist of pebbleto boulder-size basalt clasts that display a variety of textures. Many of the large boulders are composed of highly porphyritic basalt similar to that found in some dikes. Most clasts are subrounded to well rounded and are set in a matrix of altered finely comminuted basaltic glass. Fossil wood and less common clasts of white ash occur in some conglomerate beds. Locally the conglomerate is deposited on an irregular surface, with as much as $20 \mathrm{~m}$ relief, cut in basalt flows and breccia. These conglomerate beds probably represent channel deposits. In other places, such as along Eckman Creek (fig. 2) and on the south side of Heceta Head, conglomerate containing well-rounded basalt boulders as much as $2 \mathrm{~m}$ in diameter probably formed at the base of ancient sea cliffs.

Coarse-grained poorly sorted basaltic sandstone and waterlaid lapilli tuff occur in beds 1 to $12 \mathrm{~m}$ thick that are interbedded with breccia and conglomerate. The sandstone commonly is crossbedded, has scour-and-fill structures, and contains pebble conglomerate interbeds. The basaltic sandstone is composed of subangular to subrounded grains of glassy and well-crystallized basalt, scoriaceous basalt, plagioclase crystals, and a few crystals of augite. The basaltic sandstone and water-laid lapilli tuff generally are sparsely fossiliferous and contain small echinoids, spines of larger echinoids, and bryozoans, but one bed containing many large (15 cm) Pectens crops out on the north side of Heceta Head. The basaltic sandstone, conglomerate, and lapilli tuff are cut by basalt dikes that apparently were feeders to overlying basalt tuff breccia units.

Dikes and dike swarms that generally trend west or northwest are common throughout the area of outcrop of the Yachats Basalt. Dikes are particularly well exposed and abundant along the wave-cut platform between Yachats and Big Creek where several tens of dikes occur per kilometer. Swarms of dikes are also exposed on logging roads along Tenmile Creek and near Klickitat Mountain. Numerous basalt dikes of the same composition as the Yachats Basalt intrude the Tyee Formation east of the area of outcrop of the flow sequence. They are probably much more abundant than shown on figure 1, as they are only mapped where exposed in stream beds, such as the Yachats River, and along logging roads.

Dikes are typically 1 to $2 \mathrm{~m}$ wide, but larger dikes are as much as $8 \mathrm{~m}$ wide. Most dikes are irregularly jointed, others show rude columnar joints oriented normal to their margins. Flow banding is commonly well developed, particularly in dikes that contain abundant phenocrysts. The interiors of many dikes are highly vesicular. Some small dikes show irregular trends, others pinch and swell along strike. In places dikes that cut the basaltic sandstone and water-laid tuff at Heceta Head bifurcate and die out upsection in piles of submarine breccia that they presumably fed. Also in this area a $1 / 3-m$ vertical dike is inflated in two places to an ellipsoidal shape $2 \frac{1}{2} \mathrm{~m}$ wide that exhibits trough-shaped banding.

Multiple surges of magma within many dikes are indicated by symmetric vesicle zones, abrupt changes in composition, and development of multiple sets of chilled zones in dike interiors. Several felsic dikes exposed on the wave-cut platform 
below Cape Perpetua are pärticularly good examples of multiple dikes. They vary in composition from andesite at the outer margins to rhyodacite in the interiors.

\section{PETROGRAPHY}

The volcanic rocks that make up the Yachats Basalt vary widely in composition. Although the bulk of them are basalts, they grade in composition to basaltic andesite and andesite; a few dikes are rhyodicitic. Most rocks are porphyritic or glomeroporphyritic with both phenocrysts and microphenocrysts. Labradorite and less commonly augite and olivine form phenocrysts that typically make up 10 to 15 percent of the rock; microphenocrysts of apatite are also common. Hypersthene and hornblende microphenocrysts were noted in a few andesitic to rhyodacitic dikes. Most phenocrysts are 1 to $5 \mathrm{~mm}$ in longest dimension, but a few markedly porphyritic rocks contain bladelike labradorite phenocrysts more than $2 \mathrm{~cm}$ long. Labradorite phenocrysts display marked oscillatory and progressive zoning and commonly contain inclusions, particularly of devitrified glass. Cores of plagioclase phenocrysts in basalt are mostly about $\mathrm{An}_{65}$, and rims are $\mathrm{An}_{50-55}$; in more siliceous rocks the phenocrysts are sodic labradorite or andesine. Augite phenocrysts and microphenocrysts show distinct dispersion causing anomalous extinction that probably results from a relatively high titanium content even though they are not strongly colored. They show oscillatory zoning and have a $2 \mathrm{~V}$ of $50^{\circ}$ to $60^{\circ}$ and $n_{y}$ of 1.690 to 1.715. The olivine phenocrysts and microphenocrysts, mostly altered to green clay minerals, have euhedral to embayed shapes; in some rocks pyroxene reaction rims are developed around them.

The fine-grained groundmass of the volcanic rocks is composed of plagioclase, augite, opaque minerals, apatite, and glass or its clay alteration products. Altered olivine occurs in the matrix of a few rocks, and alkali feldspar is present in the matrix of some siliceous rocks. The groundmass tex ture ranges from intergranular to hyalophitic or vitrophyric and is commonly trachytic. The more siliceous rocks are markedly trachytic and very fine grained. Calcite, nontronite, analcime, natrolite, thompsonite, apophyllite, and quartz occur in amygdules in flows and as a cement in breccia.

\section{CHEMICAL COMPOSITION}

Selected chemical analyses of volcanic rocks from the Yachats Basalt are listed in table 1. Typical flow rock contains 50 percent $\mathrm{SiO}_{2}$ and is basaltic. The $\mathrm{SiO}_{2}$ content of individual analyzed flow rocks ranges from 46.7 to 56.6 percent, representing a range in composition from basalt to andesite or trachyandesite. Dikes are mostly similar in composition to flows, but a few contain 57 to 67 percent $\mathrm{SiO}_{2}$ and are andesite to rhyodacite.

The flows and dikes are characterized by high alumina, alkali, titania, and phosphate content. The high alumina content partly reflects the high content of plagioclase phenocrysts, but alumina content is also high in rocks that are aphyric or only sparsely porphyritic, indicating that the magma from which the rocks crystallized was high in alumina. Both $\mathrm{Na}_{2} \mathrm{O}$ and $\mathrm{K}_{2} \mathrm{O}$ contents are markedly higher in the more siliceous rocks, but even in typical basalts total alkalies are about $4 \frac{1}{2}$ percent. Most of the $\mathrm{K}_{2} \mathrm{O}$ and some $\mathrm{Na}_{2} \mathrm{O}$ probably occur within glass or altered glass in the interstices of the rocks, as only the most siliceous rocks contain alkali feldspar. The relatively high phosphate content is reflected in abundant apatite in the groundmass of most rocks and apatite microphenocrysts in a few. The abundance of opaque minerals in most rocks indicates that the high oxidation state of iron of analyzed rocks is a primary feature probably enhanced somewhat by weathering.

All analyzed rocks from the flows and dikes are quartz normative; most basalts have 2 to 5 percent, and some of the most siliceous rocks contain 10 to 30 percent normative quartz. Quartz in the norms of many of the basalts is due to the high oxidation state of iron. Norms, calculated on basalt analyses whose $\mathrm{Fe}_{2} \mathrm{O}_{3}: \mathrm{FeO}$ ratio has been recalculated using a ratio of 1:9, mostly show olivine, but none show nepheline. Normative plagioclase is near $A n_{50}$ in most analyzed basalt flows; those rocks less silicic than average are generally higher in $A_{n}:(A n+A b)$ and more silicic ones are lower. Analyses of andesite to rhyodacite from dikes all show normative corundum and are peraluminous. Some basaltic andesite and andesite flows contain only minor normative wollastonite or contain normative corundum, indicating that they are marginally peraluminous.

A silica versus alkalies and $\mathrm{CaO}$ diagram (fig. 3) illustrates the chemical variation shown by analyzed rocks from the Yachats Basalt. Total alkalies, and particularly $\mathrm{K}_{2} \mathrm{O}$, increase systematically with increase in $\mathrm{SiO}_{2}$. The total alkalies are 3 to 4 percent and $\mathrm{K}_{2} \mathrm{O}$ is 0.4 to 0.9 percent in rocks having the lowest $\mathrm{SiO}_{2}$ content, whereas they are 7 to 8 percent and 2.3 to 3 percent, respectively, in the most $\mathrm{SiO}_{2}$-rich rocks. With increase in $\mathrm{SiO}_{2}$ and alkalies, the rocks show a decrease in $\mathrm{CaO}$ (fig. 3), total iron, $\mathrm{MgO}, \mathrm{TiO}_{2}$, and $\mathrm{P}_{2} \mathrm{O}_{5}$.

The basalt that forms the bulk of the formation is difficult to categorize by using existing systems of nomenclature. On the basis of the norms, the basalts are olivine tholeiites and quartz tholeiites. Even though they are not nepheline normative, they have as high an alkali content as many alkalic basalts. According to Kuno's (1960) classification, they are about equally divided between alkalic olivine basalt and high-alumina basalt. On the silica-alkali plot of Macdonald and Katsura (1964), the analyses fall on both sides of the line separating tholeiitic from alkalic basalts.

The Peacock index $\left(\mathrm{SiO}_{2}\right.$ content of a rock series at which $\mathrm{CaO}$ and total alkalies are equal) of about $561 / 2$ lies nearly on the boundary (56) between calc-alkaline and alkali-calcic classes. The Yachats sequence of rocks contains more alkalies than do volcanic rocks of the western Cascades and High Cascades, whose Peacock indices are 60 and 62-64, respectively (Peck and others, 1964). 
Table 1.-Chemical analyses and norms of volcanic rocks from the Yachats Basalt

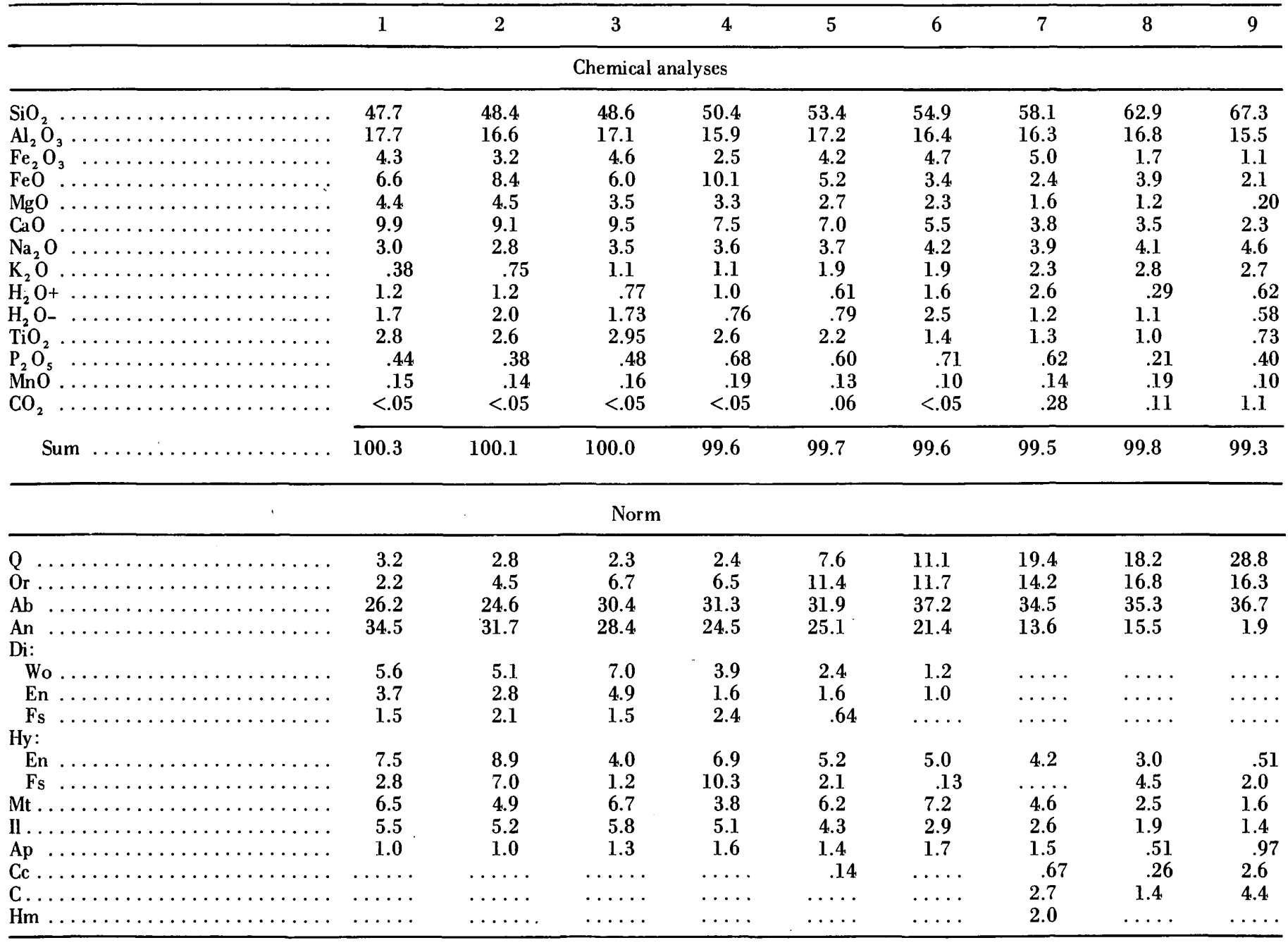

1. Breccia, SE $1 / 4$ sec. 33, T. 16 S., R. 12 W., Heceta Head quadrangle.

2. Flow, SE $1 / 4$ sec. 3 , T. 15 S., R. 12 W., Waldport quadrangle.

3. Flow, SW $1 / 4$ sec. 33, T. 13 S., R. 11 W., Waldport quadrangle.

\section{MAGMATIC HISTORY}

The wide range in composition and porphyritic character of the volcanic rocks that make up the Yachats Basalt and the abundance of multiple dikes suggest that the magma that produced the volcanic rocks was differentiated in the upper crust before extrusion. The interiors of some felsic dikes that are only 1 to $4 \mathrm{~m}$ wide contain as much as 8 percent more $\mathrm{SiO}_{2}$ than the margins (see fig. 3). The magma that formed these dikes had a heterogeneous composition that probably resulted from differentiation in relatively shallow chambers.

A large elliptical gravity anomaly is approximately centered under the outcrop area of the Yachats Basalt (Bromery and Snavely, 1964). The anomaly was originally interpreted as resulting from lower and middle Eocene Siletz River Volcanics buried at a depth of less than $1500 \mathrm{~m}$ because the Yachats Basalt flows are not sufficiently thick to cause the anomaly.
4. Flow, SW1/4 sec. 14, T. 17 S., R. 12 W., Heceta Head quadrangle. 5. Flow, NE $1 / 4$ sec. 3, T. 15 S., R. 12 W., Waldport quadrangle. 6-9. Dikes, NW1/4 sec. 3, T. 15 S., R. 12 W., Waldport quadrangle.
However, the area of most abundant dikes of Yachats Basalt, extending from Yachats south to Big Creek and inland to near Klickitat Mountain, is centered over the highest part of the gravity anomaly. Furthermore, the silicic dikes that might have resulted from tapping silicic magma that had accumulated at the top of a magma chamber seem to be restricted to the central part of the gravity anomaly. Thus an alternate interpretation is that the gravity anomaly results from a relatively large differentiated gabbroic body at shallow depth that is related to the Yachats Basalt.

The anomalous geologic setting of the subaerial flows of the Yachats Basalt sandwiched between moderately deepwater marine siltstone of the Nestucca Formation requires local uplift immediately preceding volcanism and local subsidence closely after the eruptive event. Although it can be argued that these local vertical movements may have been in response to physical or thermal changes in the mantle, they may be related 


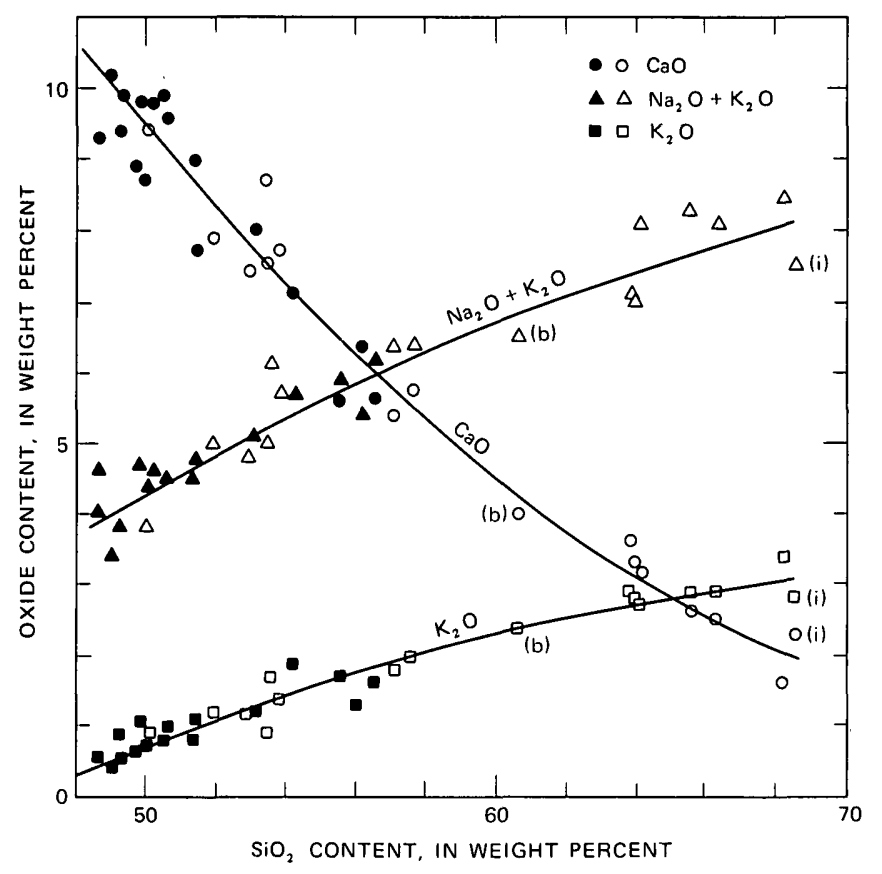

Figure 3.- $\mathrm{V}$ ariation in $\mathrm{SiO}_{2}, \mathrm{Na}_{2} \mathrm{O}, \mathrm{K}_{2} \mathrm{O}$, and $\mathrm{CaO}$ in analyzed rocks from the Yachats Basalt. Extrusive rocks are shown by filled symbols, intrusive rocks by open symbols. Analyses of the interior (i) and border (b) of a multiple dike at Cape Perpetua are indicated on diagram. Analyses recalculated water free before plotting.

to movement of the upper Eocene magma in the upper crust. We speculate that the upper crust was locally uplifted as magma was injected to form large chambers, probably within the Tyee Formation. Only a part of this magma was extruded to form the Yachats Basalt, and the remainder may have been withdrawn back into deeper chambers; then local subsidence and renewal of marine sedimentation occurred. Subsidence may have been at a slower rate than the rate of uplift because the volcanic sequence was subjected to subaerial erosion, and a thick nearshore sequence of conglomerate and basaltic sandstone formed prior to renewed moderately deepwater marine sedimentation.

If the magma chamber were within the Tyee Formation, some of the more siliceous volcanic rocks might represent contamination of the original basaltic magma by melted Tyee sandstone and siltstone. Tatsumoto and Snavely (1969) report $\mathrm{Pb}, \mathrm{U}$, and $\mathrm{Th}$ isotope data for samples of basalt and dacite from the Yachats Basalt and wacke from the Tyee Formation. The dacite contains distinctly more radiogenic $\mathrm{Pb}$ than the basalt, which suggests that contamination as well as crystal fractionation may have occurred. The $\mathrm{Pb}, \mathrm{U}$, and Th data for the Tyee, however, suggest that the dacite is not a product of contamination of a basaltic magma by Tyee sediments. For example, the $\mathrm{Pb}^{206} / \mathrm{Pb}^{204}$ ratios increase in the order Tyee wacke (19.14), basalt (19.23), and dacite (19.34).

\section{AGE AND CORRELATION}

The Yachats Basalt is assigned a late Eocene age because it is both underlain and overlain by siltstone and sandstone (Nestucca Formation) that contain a foraminiferal assemblage assigned by W. W. Rau (written commun., 1970) to the upper Narizian Stage of Mallory (1959) of late Eocene age. At Yachats, the basalt is overlain by an unnamed fossiliferous basaltic sandstone unit that contains Foraminifera of the lower Refugian Stage (W. W. Rau, oral commun., 1.970) of latest Eocene age. This sandstone unit thins northward from Yachats and grades laterally into tuffaceous siltstone and sandstone of the Nestucca Formation of late Eocene age, which immediately overlies the volcanic rocks just south of Alsea Bay along Eckman Creek.

Plagioclase separated from a platy andesitic basalt flow in the upper part of the Yachats Basalt at Cape Perpetua gave a potassium-argon date of $36.6 \pm 3.6 \mathrm{~m} . y$. (J. D. Obradovich, written commun., 1965).

Sequences of volcanic rocks that correlate with the Yachats Basalt occur in several places in the Oregon Coast Range. They include the camptonitic flows and breccias that crop out along the Siletz River, 2 to $3 \mathrm{~km}$ east of U.S. 101. (Snavely and others, 1969 and 1972a), the basalt flows at Casade Head on the coast $50 \mathrm{~km}$ north of Newport, the upper part of the Tillamook Volcanics (Warren and others, 1945) northeast of Tillamook, and the Goble Volcanics (Wilkinson and others, 1946) along the Columbia River about $20 \mathrm{~km}$ north of Portland. Each of these largely subaerial flow sequences represents local centers of late Eocene volcanism that probably formed low islands on the broad continental shelf (Snavely and Wagner, 1963).

\section{TECTONIC SETTING OF UPPER EOCENE BASALTS}

Inasmuch as the main purpose of this report is to name and describe the Yachats Basalt, only a few general comments on the magmatic evolution of these and correlative volcanic rocks in Oregon and Washington are given to call attention to regional problems that relate to the genesis of these rocks. Analysis of the magmatic and tectonic history of the late Eocene volcanic rocks in western Oregon and Washington must await the interpretation of new information now being collected on their geologic setting and petrochemistry.

Porphyritic basalt and basaltic andesite of late Eocene age are widespread in Oregon and Washington. The Yachats Basalt represents only one of several correlative volcanic sequences of this age that are interbedded with marine sedimentary rocks. Other major eruptive areas that produced flows and breccias of late Eocene age in western Oregon are located at Cascade Head, in the Tillamook Highlands, and along the Columbia River north of Portland. In Washington upper Eocene volcanic rocks occur along the lower Columbia River in the Grays River area (Wolfe and McKee, 1972) and near Longview (Livingston, 1966); farther north, upper Eocene basalt occurs in the Toutle 
River area (Roberts, 1958), in the Centralia-Chehalis coal district (Snavely and others, 1958), and east of Seattle (Vine, 1962). Late Eocene andesites associated with continental deposits are widespread along the western side of the Cascade Range (Peck and others, 1964) and in eastern Oregon (Waters and others, 1951; Peck, 1964; and Walker, 1973).

The $\mathrm{K}_{2} \mathrm{O}$ content of andesitic volcanic rocks marginal to subduction zones has been shown by Dickinson (1968) and others to increase with respect to depth to the center of the Benioff zone. If a late Eocene subduction zone were present off Oregon and Washington, it must have been oriented subparallel to the present continental margin and have dipped eastward; therefore the relative $\mathrm{K}_{2} \mathrm{O}$ content of the upper Eocene volcanic rocks would be expected to show a progressive increase from west to east. However, the relative $\mathrm{K}_{2} \mathrm{O}$ content of these volcanic rocks in western Oregon and Washington varies widely. At 55 percent $\mathrm{SiO}_{2}$, the Yachats Basalt contains about 1.6 percent $\mathrm{K}_{2} \mathrm{O}$; camptonitic volcanic rocks near the coast along the lower Siletz River contain 4.2 percent; volcanic rocks farther inland in the upper part of the Tillamook Volcanics, 1.9 percent; and the Goble Volcanics along the Columbia River north of Portland and upper Eocene volcanic rocks along the west side of the Washington Cascade Range, 0.8-0.9 percent $\mathrm{K}_{2} \mathrm{O}$. Thus the upper Eocene volcanic rocks of Oregon and Washington show no apparent eastward increase in content of $\mathrm{K}_{2} \mathrm{O}$ that would correlate with a north-trending and eastward-dipping subduction zone. Rather, the relative $\mathrm{K}_{2} \mathrm{O}$ content of the upper Eocene volcanic rocks is highest near the coast.

The upper Eocene volcanic rocks of Oregon and Washington are generally more alkaline than the calc-alkaline Quaternary volcanic rocks of the High Cascade and Aleutian Islands. This and the variations in $K_{2} \mathrm{O}$ content suggest that the volcanic rocks are probably not the product of magma generation related directly to a subduction model. Also, upper Eocene volcanism in Oregon and Washington, including that near the coast as well as in the western Cascades and eastern Oregon, was widespread and not apparently confined to a single well-defined belt of volcanoes such as are present in island arcs or Cascade-type chains that lie adjacent to and parallel to many subduction zones.

Many regional tectonic and magmatic events in the Tertiary marginal basin that occupied western Oregon and Washington probably reflect interactions between the Farallon and American plates. We speculate that the Farallon plate was underthrust near the present site of the Cascade Range in earliest Eocene time and carried the oceanic ridge basalts and seamounts (Siletz River Volcanics and Crescent Formation) eastward into their present positions in western Oregon and Washington between the Klamath Mountains and Vancouver Island. Regional uplift in the Oregon and Washington Coast Ranges and the adjacent shelf during mid-late Eocene and latest Miocene times may also have been in response to a new locus of subduction west of the Tertiary marginal basin near the present Outer Continental Shelf. The preponderance of geologic evidence in western Oregon and Washington and the adjacent continental margin suggests that from post-mid-late Eocene onward, the tectonic history was dominated by horizontal extension and vertical uplift and subsidence. The only exception is north of the Coast Ranges in the structurally complex Olympic Mountains, where major thrust faults and compressional folds were apparently formed when the generally northward-moving Tertiary Coast Range basin probably collided with the Vancouver Island buttress of thick crustal rocks. Elsewhere, the presence of elongate north-trending fault-bounded extensional offshore basins (Braislin and others, 1971), the predominance of normal faulting, and the extrusion of upper Eocene and middle Miocene basalt along generally north-trending belts all suggest tensional rifting in post-midlate Eocene time. Thus, the late Eocene volcanism in western Oregon and Washington does not appear to have been related to conventional plate models for continental margins that are characterized by deep trenches flanked by island arcs.

\section{REFERENCES CITED}

Arnold, Ralph, 1906, Geological reconnaissance of the coast of the Olympic Peninsula, Washington: Geol. Soc. America Bull., v. 17, p. $451-468$.

Baldwin, E. M., 1956, Geologic map of the Lower Siuslaw River area, Oregon: U.S. Geol. Survey Oil and Gas Inv. Map OM-186.

Braislin, D. B., Hastings, D. D., and Snavely, P. D., Jr., 1971, Petroleum potential of western Oregon and Washingtonn, in Cram, I. A., ed., Possible future petroleum provinces of North America: Tulsa, Oklahoma, Am. Assoc. Petroleum Geologists Mem. 15, p. 229-238.

Bromery, R. W., and Snavely, P. D., Jr., 1964, Geologic interpretation of reconnaissance gravity and aeromagnetic surveys in northwestern Oregon: U.S. Geol. Survey Bull. 1181-N, p. N1-N13.

Callaghan, Eugene, 1927, Geology of the Heceta Head district: Eugene, Oregon Univ., M.A. thesis, 129 p.

Dickinson, W. R., 1968, Circum-Pacific andesite types: Jour. Geophys. Research, v. 73 , no. 6 , p. $2261-2269$.

Kuno, Hisashi, 1960, High-alumina basalt: Jour. Petrology, v. 1, p. $121-245$

Livingston, V. E., Jr., 1966, Geology and mineral resources of the Kelso-Cathlamet area, Cowlitz and Wahkiakum Counties, Washington: Wash. Div. Mines and Geology Bull. 54, 110 p.

Macdonald, G. A., and Katsura, T., 1964, Chemical composition of Hawaiian lavas: Jour. Petrology, v. 5, p. 82-133.

MacLeod, N. S., and Snavely, P. D., Jr. 1973, Volcanic and intrusive rocks of the central part of the Oregon Coast Range: Oregon Dept. Geology and Mineral Industries Bull. no. 77, p. 47-74.

Mallory, V. S., 1959, Lower Tertiary biostratigraphy of the California Coast Ranges: Tusla, Okla., Am. Assoc. Petroleum Geologists, $416 \mathrm{p}$.

Peck, D. L., 1964, Geologic reconnaissance of the Antelope-Ashwood area, north-central Oregon: U.S. Geol. Survey Bull. 1161-D, p. D1-D26.

Peck, D. L., Griggs, A. B., Schlicker, H. G., Wells, F. G., and Dole, H. M., 1964, Geology of the central and northern parts of the western Cascade Range in Oregon: U.S. Geol. Survey Prof. Paper 449, 56 p.

Roberts, A. E., 1958, Geology and coal resources of the Toledo-Castle Rock district, Cowlitz and Lewis Counties, Washington: U.S. Geol. Survey Bull. 1062, 71 p. 
Snavely, P. D., Jr., Brown, R. D., Jr., Roberts, A. E., and Rau, W. W., 1958, Geology and coal resources of the Centralia-Chehalis district, Washington: U.S. Geol. Survey Bull. 1053, 159 p.

Snavely, P. D., Jr., MacLeod, N. S., and Rau, W. W., 1969, Geology of the Newport area, Oregon: Ore Bin, v. 31, no. 2 and 3, p. 25-70.

Snavely, P. D., Jr., MacLcod, N. S., and Wagner, H. C., 1968, Tholeiitic and alkalic basalts of the Eocene Siletz River Volcanics, Oregon Coast Range: Am. Jour. Sci., v. 266, no. 6, p. 454-481.

1.973, Miocene tholeiitic basalts of coastal Oregon and Washington and their relations to coeval basalts of the Columbia Plateau: Geol. Soc. America Bull., v. 84, p. 387-424.

Snavely, P. D., Jr., MacLeod, N. S., Wagner, H. C., and Rau, W. W., 1.972a, Preliminary bedrock geologic map of the Cape Foulweather and Euchre Mountain quadrangles, Oregon: U.S. Geol. Survey open-file map, scale 1:48,000.

$1972 \mathrm{~b}$, Preliminary bedrock geologic map of the Waldport and Tidewater quadrangles, Oregon: U.S. Gcol. Survey open-file map, scale $1: 48,000$.

1972c, Preliminary bedrock geologic map of the $Y_{\text {aquina and }}$ Toledo quadrangles, Oregon: U.S. Geol. Survey open-file map, scale $1: 48,000$.

Snavely, P. D., Jr., and Vokes, H. E., 1.949, Gcology of the coastal area between Cape Kiwanda and Cape Foulweather, Oregon: U.S. Geol. Survey Oil and Gas Inv. Prelim. Map 97, scale 1:62,500.

Snavely, P. D., Jr., and Wagner, H. C., 1963, Tertiary geologic history of western Oregon and Washington: Washington Div. Mines and Gcology Rept. Inv. 22, 25 p.

1964, Geologic sketch of northwestern Orcgon: U.S. Geol. Survey Bull. 11.81-M, p. M1-M17.
Tatsumoto, Mitsunobu, and Snavely, P. D., Jr., 1969, Isotopic composition of lead in rocks of the Coast Range, Oregon and Washington: Jour. Geophys. Research, v. 74, p. 1087-1100.

U.S. Geological Survey, 1969, Aeromagnetic survey composite map, Oregon Coast: U.S. Geol. Survey open-file map.

Vine, J. D., 1962, Stratigraphy of Eocene rocks in a part of King County, Washington: Washington Div. Mines and Gcology Rẹpt. Inv. $21,20 \mathrm{p}$.

Vokes, H. E., Norbisrath, Hans, and Snavely, P. D., Jr., 1.94.9, Geology of the Newport-Waldport area, Lincoln and Lane Counties, Oregon: U.S. Geol. Survey Oil and Gas Inv. Prelim. Map 88.

Walker, G. W., 1973, Preliminary geologic and tectonic maps of Oregon east of the $121^{\text {st }}$ meridian: U.S. Geol. Survey, Misc. Field Studies Map MF-495.

Warren, W. C., Norbisrath, Hans, and Grivetti, R. M., 1945, Geology of northwestern Oregon, west of Willamette River and north of latitude $45^{\circ} 15^{\prime}$ : U.S. Geol. Survey Oil and Gas Inv. Prelim. Map 4.2.

Washburne, C. W., 1914, Reconnaissance of the geology and oil prospects of northwestern Oregon: U.S. Geol. Survey Bull. 50, $111 \mathrm{p}$.

Waters, A. C., and others, 1951, Quicksilver deposits of the Horse Heaven Mining district, Oregon: U.S. Gcol. Survey Bull. 969-E, p. 1.05-14.9.

Wilkinson, W. D., Lowry, W. D., and Baldwin, E. M., 194.6, Geology of the St. Helens quadrangle, Oregon: Oregon Dept. Geology and Mineral Industries Bull. no. 31, p. 1-39.

Wolfe, E. W. and McKee, E. H., 1972, Sedimentary and igneous rocks of the Grays River quadrangle, Washington: U.S. Geol. Survey Bull. $1335,70 \mathrm{p}$. 


\title{
RELATION OF MINERALIZATION TO CALDERAS IN THE SAN JUAN VOLCANIC FIELD, SOUTHWESTERN COLORADO
}

\author{
BY THOMAS A. STEVEN, ROBERT G. LUEDKE, and PETER W. LIPMAN, \\ Denver, Colo., Washington, D.C., Denver, Colo.
}

\begin{abstract}
A review of the calderas in the San Juan volcanic field, southwestern Colorado, indicates that lead, zinc, copper, gold, and silver mineralization took place in and near calderas which had complex histories of postsubsidence intrusive and extrusive igneous activity. Most known ore occurs in veins that follow fractures formed during the different caldera cycles, but some intrusive bodies were extensively mineralized and possibly may host disseminated, porphyry-type deposits. The mineral deposits seem to be related most commonly to the youngest and most highly differentiated late intrusives of a caldera cycle.
\end{abstract}

Major mining districts in the San Juan volcanic field in which significant lead, zinc, copper, gold, and silver ores have been developed are closely associated with large calderas that formed as a result of catastrophic ash-flow eruptions in middle Tertiary time. Most known ore occurs in veins that filled or replaced the walls of fractures that formed during the different caldera cycles, but some intrusive bodies were extensively mineralized and possibly may host disseminated, porphyrytype deposits. So far as known, less than half of the calderas in the San Juan Mountains are significantly mineralized, and why some calderas localized mineralization, whereas others did not, is of considerable economic and scientific interest. We conclude that the extent of postsubsidence igneous and structural activity is especially significant and that ore deposition was associated with calderas which had the longest and most complex late histories. This conclusion agrees well with the sequence of events outlined by Smith and Bailey (1968, p. 643), who suggest in their review of resurgent cauldrons that mineralization is generally associated with terminal stages of the caldera cycle.

\section{GENERAL GEOLOGY}

Major igneous activity in the San Juan volcanic field began in early Oligocene time, probably between 40 and 35 m.y. ago, with the eruption of andesitic to rhyodacitic lavas from many widely scattered volcanoes (Lipman and others, 1970). These volcanoes were especially active 35-30 m.y. ago, when deposits from them and similar volcanic and volcaniclastic deposits in adjacent areas coalesced into a great field that covered much of southern and central Colorado (Steven and Epis, 1968;
Lipman and others, 1970). Beginning about $30 \mathrm{~m} . \mathrm{y}$. ago, the character of the volcanism changed, and voluminous silicic ash-flow eruptions with concurrent caldera subsidence of the source areas dominated until the end of Oligocene time about 26 m.y. ago. In early Miocene, about coincident with inception of widespread basin-and-range faulting in the Western United States, the composition of volcanic rocks in the San Juan field changed from intermediate through silicic lavas and pyroclastics to a bimodal assemblage of basalts and rhyolites. One of the later rhyolites was erupted as large-volume ash flows, with related caldera subsidence.

The distribution of known calderas in the San Juan volcanic field is shown in figure 1; the features of the calderas and the ages of associated ash-flow sheets are summarized in table 1. All but one caldera formed as a result of intermediate or silicic ash-flow eruptions in Oligocene time; the exception, the Lake City caldera, formed in early Miocene time during the period of basalt and rhyolite eruptions. Six of the San Juan calderas have associated mining districts; these are of all ages, including some of the oldest (Bonanza and Summitville), some of intermediate age (Uncompahgre, San Juan, and Silverton) and the two youngest (Creede and Lake City). The chief common distinguishing features of the mineralized calderas are complex postsubsidence structural disruption, igneous activity, and extensive hydrothermal activity.

Many of these relations are summarized in table 1 , and will be discussed briefly in the following individual descriptions of caldèras.

\section{BONANZA CALDERA}

Little is known about the relation of mineralization to the Bonanza caldera in the northeastern part of the San Juan volcanic field (fig. 1). The only comprehensive discussion of the mineral deposits is by Burbank (1932), whose work there was done before his pioneer recognition of calderas in the western San Juan Mountains (Burbank, 1933). Karig (1965) inferred a caldera in the Bonanza area from the presence of a pronounced negative gravity anomaly. Mayhew (1.969) and Knepper and Marrs (1971) have summarized some of the 


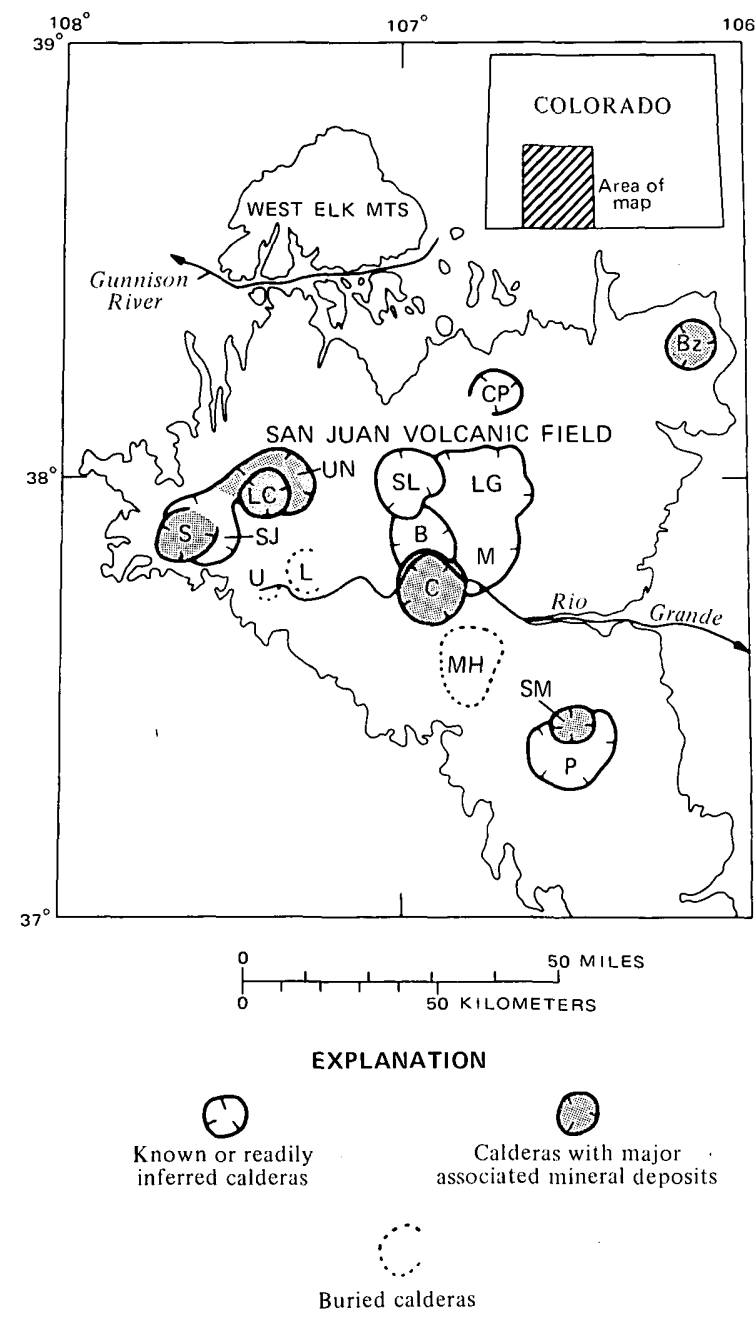

Figure 1.-Map of San Juan volcanic field showing calderas: S, Silverton; LC, Lake City; CP, Cochetopa Park; Bz, Bonanza; LG, La Garita; SL, San Luis; B, Bachelor; C, Creede; MH, Mount Hope; P, Platoro; SM, Summitville; L, Lost Lake; U, Ute Creek; SJ, San Juan; UN, Uncompahgre; $M$, general area of the Mammoth Mountain caldera.

general features of the caldera. Inasmuch as details of the geology and of age relations to the associated ore deposits are not available, only limited comparisons can be made between Bonanza and the other calderas in the San Juan area.

\section{PLATORO AND SUMMITVILLE CALDERAS}

The Platoro and Summitville calderas form a dual structure that subsided in response to repeated eruptions of the Treasure Mountain Tuff 30-29 m.y. ago (Lipman and Steven, 1970; Lipman, 1974). The older and larger Platoro caldera, about 20 $\mathrm{km}$ across, formed during eruption of the La Jara Canyon Member of the Treasure Mountain Tuff. The core of this caldera was strongly domed by magmatic resurgence shortly after subsidence, and the low-lying marginal moat was then filled to overflowing with dark andesitic lavas. Later ash-flow eruptions of the Ojito Creek and Ra Jadero Members caused the smaller Summitville caldera, about $10 \mathrm{~km}$ across, within the northern part of the main caldera to subside; this younger caldera apparently was not resurgent but was filled with dark andesites. The western, southern, and eastern periphery of the younger caldera localized repeated faulting and intrusive and extrusive igneous activity after the caldera was filled, and the adjacent rocks were extensively altered during several episodes of hydrothermal activity related to emplacement of different intrusive bodies. Major amounts of copper-gold-silver ore were deposited in the Summitville district (Steven and Ratté, 1960) late in this period of postsubsidence igneous activity, and anomalous concentrations of various metals are known at other places around the altered and intruded periphery (Calkin, 1967; Sharp and Gualtieri, 1968). Gold-silver veins have also been worked along radial fissure zones in the Stunner-Gilmore district (not shown in fig. 1.) and in the Platoro district (Patton, 1917).

We are impressed by the number of intrusive bodies and the extent of hydrothermally altered rocks related to the younger caldera margin and by the complex history of faulting, intrusion, and alteration that followed the filling of the caldera by andesitic lavas. The intrusions range from granodiorite to quartz monzonite (quartz latite) and from equigranular to coarsely porphyritic. The known mineral deposits generally seem to be associated with the younger, more differentiated intrusive and ex trusive rocks.

\section{CREEDE CALDERA}

The Creede caldera (Steven and Ratté, 1965) is the youngest of a cluster that subsided along the western periphery of the older and larger La Garita caldera in latest Oligocene time (fig. 1). The Creede caldera formed concurrently with eruption of the Snowshoe Mountain Tuff which accumulated to a thickness of more than $1.5 \mathrm{~km}$ and perhaps to more than $2 \mathrm{~km}$ within the caldera but which is relatively thin outside. After subsidence, the core of the caldera was strongly domed. Viscous lavas of the Fisher Quartz Latite were extruded from numerous vents aroung the marginal moat, which elsewhere filled with volcanic ash, stream and lake sediments, and travertine of the Creede Formation. Shortly after the Creede Formation was deposited, a graben that originally developed along the axis of the Bachelor caldera resurgent dome (fig. 1) was reactivated as a structural feature radial to the Creede caldera, trending north-northwest outward from its north side. This graben was strongly mineralized during the closing stages of faulting when the silver-lead-zinc veins of the Creede district formed. Displacement along the graben faults is slight near the caldera margin, attains the maximum a few kilometers north, and gradually diminishes until it can no longer be discerned about $10 \mathrm{~km}$ from the caldera margin. The faulting thus appears to mark local distention just outside the caldera margin and may reflect forceable emplacement of a local intrusive body at depth that may have been the source of the mineralizing solutions (Steven, 1971). 
The time encompassed by the postsubsidence extrusion of Fisher Quartz Latite, deposition of the Creede Formation, graben faulting, and mineralization in the Creede district must have been brief. Eruption of Snowshoe Mountain Tuff and concurrent subsidence of the Creede caldera is bracketed by K-Ar dates of 26.4 m.y. for the younger Fisher Quartz Latite and 26.7 m.y. for the older Mammoth Mountain Tuff (Lipman and others, 1970). A date of $26.5 \mathrm{~m} . y$. was obtained from one of the older Fisher flows, and a date of $26.4 \mathrm{~m} . \mathrm{y}$. from one of the youngest. Preliminary K-Ar data from impure adularia from the $\mathrm{OH}$ vein obtained by Philip Bethke, U.S. Geological Survey (oral commun., 1968), and reported by Steven (1969), suggest that mineralization took place around 26 m.y. ago. Although these dates are in correct sequence, the differences are less than the precision of the K-Ar method. The dates do indicate, however, that the complex postsubsidence activity around the Creede caldera was short lived.

\section{UNCOMPAHGRE, SAN JUAN, AND SILVERTON CALDERAS}

Major collapse of the Uncompahgre and San Juan calderas took place concurrently with eruption of the Sapinero Mesa Tuff between 28.4 and 27.8 m.y. ago (Lipman and others, 1973). The Sapincro Mesa Tuff had an original volume of more than $1,000 \mathrm{~km}^{3}$, and covered most of the western and northern parts of the San Juan volcanic field. The Silverton caldera, nested within the San Juan caldera, formed slightly later in response to eruption of the Crystal Lake Tuff, which was confined largely within the earlier depressions. The latter stages of the cycles of development of all three calderas overlapped and are indistinguishable. Most of the ores that have been mined from this highly productive area were deposited during this period, or during subsequent periods of igneous activity that utilized earlier fracture systems.

Eruption of the Sapinero Mesa Tuff and collapse of the San Juan and Uncompahgre calderas progressed concurrently. Outflow Sapinero Mesa Tuff is generally $70 \mathrm{~m}$ or less thick, whereas the intracaldera Eureka Member is locally as much as $700 \mathrm{~m}$ thick. Lithic debris is common in the Eureka Member, and landslide debris interleaves marginally near the steep caldera walls. After virtually simultaneous collapse of the two calderas, the subsided areas were filled with a complex accumulation of intermediate lavas, breccias, and volcanic sediments. Equivalent volcanics outside the calderas are now preserved only east and southeast of the San Juan caldera.

About midway through the San Juan and Uncompahgre caldera cycles, the central San Juan Mountains became a major source area for ash-flow deposits. The distal parts of four ashflow sheets from the central San Juans extend into the caldera area in the western San Juans. Present remnants occur only around the eastern and northern margins of the Uncompahgre caldera and the northeastern margin of the San Juan caldera.

The Crystal Lake Tuff, which is interlayered between ashflow sheets from the central San Juan Mountains, appears to have been erupted from the Silverton caldera, nested within the older San Juan caldera. Ring fractures of the Silverton caldera bound a tilted, trapdoor-style subsided block of older caldera-filling volcanics that sank $700 \mathrm{~m}$ or more on its south and southeast sides, but had virtually no displacement along its north margin. Numerous dikes, plugs, and stocks of intermediate to silicic composition were emplaced along this late ring-fracture zone.

The Uncompahgre, San Juan, and Silverton calderas were resurgently dorned together, apparently over an extended period of time beginning shortly after subsidence of the older two calderas and continuing after development of the younger caldera. A broad, low dome extends from the east side of the Uncompahgre caldera to the west side of the San Juan and Silverton calderas. A northeast-trending apical graben (the Eureka graben) formed along the crest of the-dome, and numerous other fractures developed within the caldera fills and in the adjacent wallrocks.

Major ore deposits were deposited in faults and fractures formed during the combined San Juan, Uncompahgre, and Silverton caldera cycles (Burbank and Luedke, 1968; Steven and others, 1973). Numerous intermediate to silicic intrusive bodies cut the caldera fills and are especially abundant along the ring-fracture zone of the Silverton caldera. Many of these bodies are altered and mineralized, and nearby fractures commonly contain metalliferous veins. The Red Mountain district along the northwest side of the Silverton caldera was the center of especially intense alteration and mineralization, and a series of rich and persistent radial veins extends more than $1.0 \mathrm{~km}$ northwestward out into the caldera wall. These veins currently supply most of the ore being mined in the western San Juan Mountains.

Economically important veins also were deposited in fractures along the crest of the resurgent dome that uplifted the cores of the Uncompahgre, San Juan, and Silverton calderas. Many other local intrusive bodies emplaced within and adjacent to the Uncompahgre and San Juan calderas after subsidence also were variably altered and are surrounded by mineralized areas containing metalliferous veins along fractures. These bodies are abundant south and east of Silverton, and in the Engineer Mountain-Red Mountain Creek area around the periphery of the San Juan caldera, and near Henson Creek and the Lake Fork of the Gunnison River along the north and east sides of the Uncompahgre caldera.

\section{LAKE CITY CALDERA}

The Lake City caldera subsided about 22.5 m.y. ago during large-scale eruptions of siliceous rhyolite ash flows of the Sunshine Peak Tuff (Mehnert and others, 1973). A block about $13 \mathrm{~km}$ across subsided concurrently with eruption, and the Sunshine Peak Tuff is about $1 \mathrm{~km}$ thick within the caldera, but only a few tens of meters thick outside. The core of the caldera was domed after subsidence, and some dikes and plugs 
Table 1.-Calderas of the San Juan volcanic field

\begin{tabular}{|c|c|c|c|c|c|}
\hline Caldera & State of knowledge & $\begin{array}{l}\text { Associated ash-flow } \\
\text { sheet (age given } \\
\text { in parentheses) }\end{array}$ & Resurgence & Mineralization & $\begin{array}{c}\text { Postcaldera igneous activity } \\
\text { (subjective rating given in parentheses) }\end{array}$ \\
\hline Lake City . & Detailed & $\begin{array}{l}\text { Sunshine Peak Tuff } \\
(22.5 \text { m.y.). }\end{array}$ & Strong . & $\begin{array}{l}\text { Moderate. Widespread hydrother- } \\
\text { mal alteration. }\end{array}$ & $\begin{array}{l}\text { Large neck with associated flows on east rim: nu- } \\
\text { merous int rusions around north margin and } \\
\text { within resurgent core (major). }\end{array}$ \\
\hline Creede .... & Detailed & $\begin{array}{l}\text { Snowshoe Mountain } \\
\text { Tuff (slightly older } \\
\text { than } 26.4 \text { m.y.). }\end{array}$ & Strong & $\begin{array}{l}\text { Major. Largest metal producer } \\
\text { outside the Silverton caldera } \\
\text { area. }\end{array}$ & $\begin{array}{l}\text { Numrrous intrusives and flows around rim and } \\
\text { along radial graben in Creede district (major). }\end{array}$ \\
\hline Cochetopa Park & Detailed reconnaissance & $\begin{array}{l}\text { Nelson Mountain Tuff } \\
\text { (bet ween } 26.7 \text { and } \\
26.4 \text { m.y.). }\end{array}$ & None $\ldots \ldots \ldots$ & None known $\ldots \ldots \ldots \ldots \ldots$ & $\begin{array}{l}\text { One: largre voleanic dome in center of caldera } \\
\text { (minor). }\end{array}$ \\
\hline San Luis . .......... & $\begin{array}{l}\text { South margin detailed, rest } \\
\text { reconnaissance. }\end{array}$ & $\begin{array}{l}\text { Kat Creek Tuff (be- } \\
\text { tween } 26.7 \text { and } 26.4 \\
\text { m.y.). }\end{array}$ & Strong $\ldots \ldots \ldots$ & $\begin{array}{l}\text { Minor. Local hydrothermal altera- } \\
\text { tion. }\end{array}$ & $\begin{array}{l}\text { Numerous intrusives and lavas along cast and } \\
\text { north rim. Later activity widespread just weest } \\
\text { of caldera (major). }\end{array}$ \\
\hline Mammoth Mountain & $\begin{array}{l}\text { Poorly known. Mostly cov- } \\
\text { ered by younger rocks. }\end{array}$ & $\begin{array}{l}\text { Mammoth Mountain } \\
\text { Tuff ( } 26.7 \text { m.y. }) \text {. }\end{array}$ & Probably none.. & None known $\ldots \ldots \ldots \ldots \ldots$ & $\begin{array}{l}\text { Numerous flows along northeast rim (mod- } \\
\text { erate?). }\end{array}$ \\
\hline Bachelor ... & Detailed of exposed part .. & $\begin{array}{l}\text { Carpenter Ridge Tuff } \\
\text { (between } 27.8 \text { and } \\
26.7 \text { m.y.). }\end{array}$ & Strong .. & $\begin{array}{l}\text { None known. Local hydrothermal } \\
\text { alteration. }\end{array}$ & Some concurrent lavas along west rim (minor). \\
\hline Silverton .... & Detailed & $\begin{array}{l}\text { Crystal Lake Tuff (be- } \\
\text { tween } 27.8 \text { and } 26.7 \\
\text { m.y.). }\end{array}$ & Moderate(?) & $\begin{array}{l}\text { Major. Widespread hydrothermal } \\
\text { alteration. Has supplied about } \\
\text { two-thirds of metal production } \\
\text { from San Juan region. }\end{array}$ & Numerous int rusives (major). \\
\hline & $\begin{array}{l}\text { Partly detailed; rest recon- } \\
\text { naissance. }\end{array}$ & $\begin{array}{l}\text { Fish Canyon Tuff ( } 27.8 \\
\text { m.y.). }\end{array}$ & Strong & None known $\ldots \ldots \ldots \ldots \ldots$ & None known. \\
\hline Mount Hope & $\begin{array}{l}\text { Poorly known; buried by } \\
\text { younger rocks. }\end{array}$ & $\begin{array}{l}\text { Masonic Park Tuff (be- } \\
\text { tween } 29.8 \text { and } 27.8 \\
\text { m.y.). }\end{array}$ & Weak. & None known & Concurrent flows along northwest rim (minor). \\
\hline $\begin{array}{l}\text { San Juan and Uncom. } \\
\text { pahgre. }\end{array}$ & Detailed & $\begin{array}{l}\text { Sapinero Mesa Tuff (be- } \\
\text { tween } 28.4 \text { and } 27.8 \\
\text { m.y.). }\end{array}$ & Strong . & $\begin{array}{l}\text { Major. Cannot every wherc be dis. } \\
\text { tinguished from mineralization } \\
\text { associated with Silverton cal. } \\
\text { dera. }\end{array}$ & $\begin{array}{l}\text { Numerous flows and intrusives within the two } \\
\text { calderas (major). }\end{array}$ \\
\hline Lost Lake (probable) & $\begin{array}{l}\text { Poorly known; buried by } \\
\text { younger rocks. }\end{array}$ & $\begin{array}{l}\text { Blue Mesa(?) Tuff (be- } \\
\text { tween } 28.4 \text { and } 27.8 \\
\text { m.y.). }\end{array}$ & None & None known & None known. \\
\hline Ute Ridge (probable) . & $\begin{array}{l}\text { Poorly known; largely bur- } \\
\text { ied by younger rocks. }\end{array}$ & $\begin{array}{l}\text { Ute Ridge(?) Tuff } \\
\text { (28.4? m.y.). }\end{array}$ & Probably none... & $\begin{array}{l}\text { None known. Some hydrothermal } \\
\text { alteration. }\end{array}$ & $\begin{array}{l}\text { Several intrusives exposed near southeast rim (mi. } \\
\text { nor or moderatc). }\end{array}$ \\
\hline $\begin{array}{l}\text { Platoro and Summit- } \\
\text { ville. }\end{array}$ & Detailed & $\begin{array}{l}\text { Treasure Mountain Tuff } \\
(29.8 \text { m.y. }) \text {. }\end{array}$ & Strong . & $\begin{array}{l}\text { Major. Widespread hydrothermal } \\
\text { alteration. }\end{array}$ & $\begin{array}{l}\text { Numerous flows and intrusives within the two } \\
\text { nested calderas, and around the rim of the } \\
\text { younger (major). }\end{array}$ \\
\hline Bonanza . & Poorly known . & Bonanza Tuff . . . . . . . & Probably strong. & $\begin{array}{l}\text { Major. Widespread hydrothermal } \\
\text { alteration. }\end{array}$ & Insufficiently known to be classified. \\
\hline
\end{tabular}

of the resurgent magma penetrated the base of the Sunshine Peak Tuff, within a kilometer of the surface, where they crystallized as coarse-grained porphyritic granite. A large plug dome (Red Mountain) was emplaced along the eastern ringfracture zone, probably after resurgence, and related quartz latite and rhyolite flows accumulated nearby in the marginal moat. A related series of rhyolite plugs, sills, and laccoliths were emplaced along an east-trending line north of the Lake City caldera, roughly along the trend of the buried ringfracture zone of the older Uncompahgre caldera.

The plug dome at Red Mountain was intensely altered after emplacement, and anomalous metal contents perhaps indicative of disseminated mineralization have been reported (D. N. Stevens, Earth Sciences, Inc., oral commun., 1973). Numerous veins formed in fractures adjacent to the altered plug and elsewhere in the caldera; some of these cut the domed core, and some are along the marginal fault. To date, production from the veins clearly related to the Lake City caldera has been small.

\section{OTHER CALDERAS}

Some weakly mineralized calderas also have extensive associated lavas and intrusives; but, in most of these, extrusion and intrusion were relatively brief and either accompanied subsidence and resurgence or occurred shortly thereafter. The large mass of lavas along the northwest side of the apparently barren Mount Hope caldera formed between eruptions of the lower and upper members of the Masonic Park Tuff and thus accumulated during the period of ash-flow eruptions and subsidence. The large volume of lavas and breccias around the San Luis caldera falls into two groups: (1) Marginal extrusions around the eastern and northern ring-fracture zone, and (2) a group of volcanoes that extends $8 \mathrm{~km}$ west from the southwestern periphery of the caldera. The first group was erupted concurrently with subsidence and resurgence and shows little evidence of hydrothermal activity; however, some fractures within the nearby resurgent core contain small lead-zinc-silver veins. The volcanoes extending west from the caldera formed after subsidence and resurgence and some of these have large associated areas of intensely altered rocks. Locally, the altered areas contain anomalous quantities of metal, although no ore deposits have been discovered to date. Perhaps the lack of known ore deposits in the vicinity of these volcanoes reflects in part the general absence of fracturing in this structurally simple area. Numerous fractures for channeling of hydrothermal solutions may be essential for an extracaldera area to be widely mineralized.

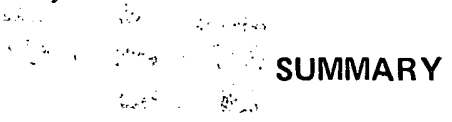

Mineralized areas in the San Juan volcanic field are most commonly associated with calderas that have the most complex postsubsidence 'histories. Resurgence seems to have had little bearing on the process of mineralization, for although most of the strongly mineralized calderas are resurgent, so are 
most of the nonmineralized to weakly mineralized calderas. In addition, mineralization that was associated with the Platoro caldera seems to have been closely tied to the younger, nonresurgent segment of the compound structure. Most of the San Juan mineral deposits are associated with relatively silicic, highly differentiated rocks, and these in turn are most commonly found as young intrusive and extrusive bodies in and around calderas that have complex late histories.

Nothing in the process of ash-flow eruption or related caldera subsidence leads inherently to hydrothermal activity and mineralization. Eruption and subsidence, rather, create favorable plumbing systems in areas of active magmatism; whether these systems are used by ore-forming solutions depends on the extent of later igneous activity and on continued structural disruption that keeps the systems open. Recurrent intrusions along structurally complex ring-fracture zones and adjacent areas seem to be the most common events closely associated with mineralization; seemingly, the more complex the history of this late ring-fracture igneous activity, the better the chances for mineralization. Mineral deposits seem to be most commonly associated with the youngest and perhaps most highly differentiated of the ring-fracture intrusions. The related mineralization most commonly takes place in fractures extending outward from the caldera walls; and a zone several kilometers wide around the periphery of a mineralized caldera generally contains the most, the largest, and the highest grade deposits.

\section{REFERENCES CITED}

Burbank, W. S., 1932, Geology and ore deposits of the Bonanza mining district, Colorado: U.S. Gcol. Survey Prof. Paper 169, $166 \mathrm{p}$.

1933, Vein systems of the Arrastre Basin and regional geologic structure in the Silverton and Telluride quadrangles, Colorado: Colorado Sci. Soc. Proc., v. 13, no. 5, p. 135-214.

Burbank, W. S., and Luedke, R. G., 1968, Geology and ore deposits of the western San Juan Mountains, Colorado, in Ridge, J.D., ed., Ore deposits of the United States, 1933-1.967 (Graton-Sales volume): New York, Am. Inst. Mining, Metall., Petroleum Engineers, v. 1, p. 714-733.

Calkin, W. S., 1967, Geology, alteration, and mineralization of the Alum Creek area, San Juan volcanic field, Colorado: Golden, Colorado School Mines, Ph. D. thesis, 177 p.

Karig, D. E., 1965, Gcophysical evidence of a caldera at Bonanza, Colorado, in Geological Survey research 1965: U.S. Geol. Survey Prof. Paper 525-B, p. B9-B12.

Knepper, D. H., and Marrs, R. W., 1971, Geological development of the Bonanza-San Luis Valley-Sangre de Cristo Range area, south-central Colorado, in James, H. L., ed., Guidebook of the San Luis basin, Colorado: New Mexico Geol. Soc., 22d Field Conf., p. 249-264.
Lipman, P. W., 1974, Geologic map of the Platoro caldera area, southcastern San Juan Mountains, Colorado: U.S. Geol. Survey Misc. Geol. Inv. Map I-828. (In press.)

Lipman, P. W., and Steven, T. A., 1970, Reconnaissance geology and economic significance of the Platoro caldera, southeastern San Juan Mountains, Colorado, in Geological Survey research 1970: U.S. Geol. Survey Prof. Paper 700-C, p. C19-C29.

Lipman, P. W., Steven, T. A., Luedke, R. G., and Burbank, W. S., 1973, Revised volcanic history of the San Juan, Uncompahgre, Silverton, and Lake City calderas in the western San Juan Mountains, Colorado: U.S. Geol. Survey Jour. Research, v. 1, no. 6, p. 627-642.

Lipman, P. W., Steven, T. A., and Mehnert, H. H., 1970, Volcanic history of the San Juan Mountains, Colorado, as indicated by potassium-argon dating: Geol. Soc. America Bull., v. 81, no. 8, p. 2329-2351.

Mayhew, J. D., 1969, Gcology of the castern part of the Bonanza volcanic field, Saguache County, Colorado: Golden, Colorado School Mines, M.S. thesis, 94 p.

Mehnert, H. H., Lipman, P. W., and Steven, T. A., 1973, Age of the Lake City caldera and related Sunshine Peak Tuff, western San Juan Mountains, Colorado: Isochron West, no. 6, p. 31-33.

Patton, H. B., 1.917, Gcology and ore deposits of the Platoro-Summitville mining district, Colorado: Colorado Geol. Survey Bull. 13, 122 p. [1918].

Sharp, W. N., and Gualtieri, J. L., 1968, Lead, copper, molybdenum, and zinc geochemical anomalies south of the Summitville district, Rio Grande County, Colorado: U.S. Geol. Survey Circ. 557, 7 p.

Smith, R. L., and Bailey, R. A., 1968, Resurgent cauldrons, in Coats, R. R., Hay R. L., and Anderson, C. A., eds., Studies in volcanology-A memoir in honor of. Howel Williams: Geol. Soc. America Mem. 11.6, p. 613-662.

Steven, T. A., 1969, Possible relation of mineralization to thermal springs in the Creede district, San Juan Mountains, Colorado-a discussion [of paper by D. E. White]: Econ. Gcology, v. 64, no. 6, p. $696-698$

1971, Geologic environment of ore deposition in the Creede district, San Juan Mountains, Colorado [abs.]: Econ. Geology, v. 66, no. 8 , p. 1270 .

Steven, T. A., and Epis, R. C., 1968, Oligocene volcanism in southcentral Colorado, in Epis, R. C., ed., Cenozoic volcanism in the southern Rocky Mountains: Colorado School Mines Quart., v. 63, no. 3 , p. 241-258.

Steven, T. A., and Ratté, J. C., 1960, Geology and ore deposits of the Summitville district, San Juan Mountains, Colorado: U.S. Geol. Survey Prof. Paper 343, 70 p.

1965, Geology and structural control of ore deposition in the Creede district, San Juan Mountains, Colorado: U.S. Gcol. Survey Prof. Paper 487, $90 \mathrm{p}$.

Steven, T. A., Lipman, P. W., Fisher, F. S., Bieniewski, C. L., and Meeves, H. C., 1973, Mincral resources of study areas contiguous to the Uncomphagre Primitive Area, San Juan Mountains, southwestern Colorado, with a section on Interpretation of aeromagnetic data, by Peter Popenoe and R. G. Luedke: U.S. Gcol. Survey open file rept., $205 \mathrm{p}$. 


\title{
STRATIGRAPHIC EVIDENCE ON THE AGE OF THE ROBERTS MOUNTAINS THRUST, EUREKA AND WHITE PINE COUNTIES, NEVADA
}

\author{
By T. B. NOLAN, Washington, D. C.
}

\begin{abstract}
Several stratigraphic discontinuities in Devonian and Mississippian sedimentary sequences in folded thrust plates east of the Roberts Mountains thrust of central Nevada indicate that the thrust was sporadically active during this interval. From estimates for displacement and time involved for the thrust, the average rate of movement was $1 \mathrm{~cm} / 5 \mathrm{yr}$, which is comparable to current concepts of the rate of orogenic movements.

A further extrapolation of this rate to the longer period during which orogenies have been recognized in the Great Basin suggests total horizontal shortening of 400 to $500 \mathrm{mi}(640-800 \mathrm{~km})$.
\end{abstract}

The Roberts Mountains thrust fault is the dominant structural feature of central Nevada (Merriam and Anderson, 1942 , p. 1.701-1702). The thrust has juxtaposed two lithologically different sequences of Paleozoic sedimentary rocks; the horizontal displacement has been estimated to be at least $60 \mathrm{mi}(96 \mathrm{~km})$. It is exposed over a strike length of more than $1.00 \mathrm{mi}(1.60 \mathrm{~km})$ and, as a result of later deformation, nearly this amount normal to the strike. West of Eureka, the thrust, in places, is locally closely folded or even overturned (Gilluly and Gates, 1965, p. 105-109).

In most of the areas in which the thrust has been mapped, it has not been possible to determine its age precisely. Commonly, the date of thrusting has been reported as between limits established by the age of the youngest rocks affected by the thrust and the oldest rocks that clearly postdate its formation. This procedure, as applied at several localities, led Roberts and others $(1958$, p. 2850$)$ to conclude that the time of thrusting extended from latest Devonian to Early Pennsylvaniar time and that it "probably comprised several distinct pulses taking place at different times throughout the region." In the Pine Valley area, south of Carlin, Smith and Ketner $(1968$, p. 1) for example, determined that the Roberts Mountains thrust involved rocks of late Late Devonian (Famennian) age and was overlapped by beds of Early Mississippian (late Kinderhookian) age. South of this region, however, in the vicinity of Devils Gate, the thrust cuts beds assigned to the Diamond Peak Formation of Late Mississippian age (Merriam 1963, p. 57). Gilluly and Gates (1965, p. 97), in reviewing the evidence for the age of thrusting, concluded that "it is perhaps not surprising that a structure so large as the Roberts Thrust should have been active at different times in different segments . . . it is not at all unlikely that the fault has been several times rejuvenated in different segments." They thus introduced the concept that not only did thrusting occur at different places at different times, but that it may have been subject to renewed movement at the same locality; no specific locality for this expanded concept was cited, however.

Another method for dating the time of thrusting is based on the lithologic character of sediments deposited in areas bordering the active orogenic zone. Gilluly and Gates (1965, p. 97-98), for example, called attention to the conglomerates in the Upper Mississippian Diamond Peak Formation in the Diamond Range and suggested that this is an indication of active orogeny in the hinterland. This approach, however, could be questioned, as the conglomerates might have resulted from accelerated erosion from highlands formed at an earlier time.

Still another stratigraphic approach is based on the presence of discontinuities in the sedimentary sequences in the areas bordering the thrust. The Eureka and Pinto Summit quadrangles, in Eureka and White Pine Counties, are just east of the easternmost outcrops of the Roberts Mountains thrust and expose several sedimentary sequences ranging from Middle Devonian to Early Pennsylvanian-supposedly the span of activity of the Roberts Mountains thrust.

These sequences, especially those that include the Lower Mississippian Joana Limestone and the formations above and below it, are particularly instructive, as they occur in several different thrust plates that are now juxtaposed but must originally have been several miles apart. The thrust plates have been folded into a series of five parallel antiforms and synforms that preserve originally more westerly sequences in the synforms and more easterly sequences in the antiforms.

Five bands of outcrops of these formations, with strike lengths of several miles, are found within the two quadrangles (fig. 1). 


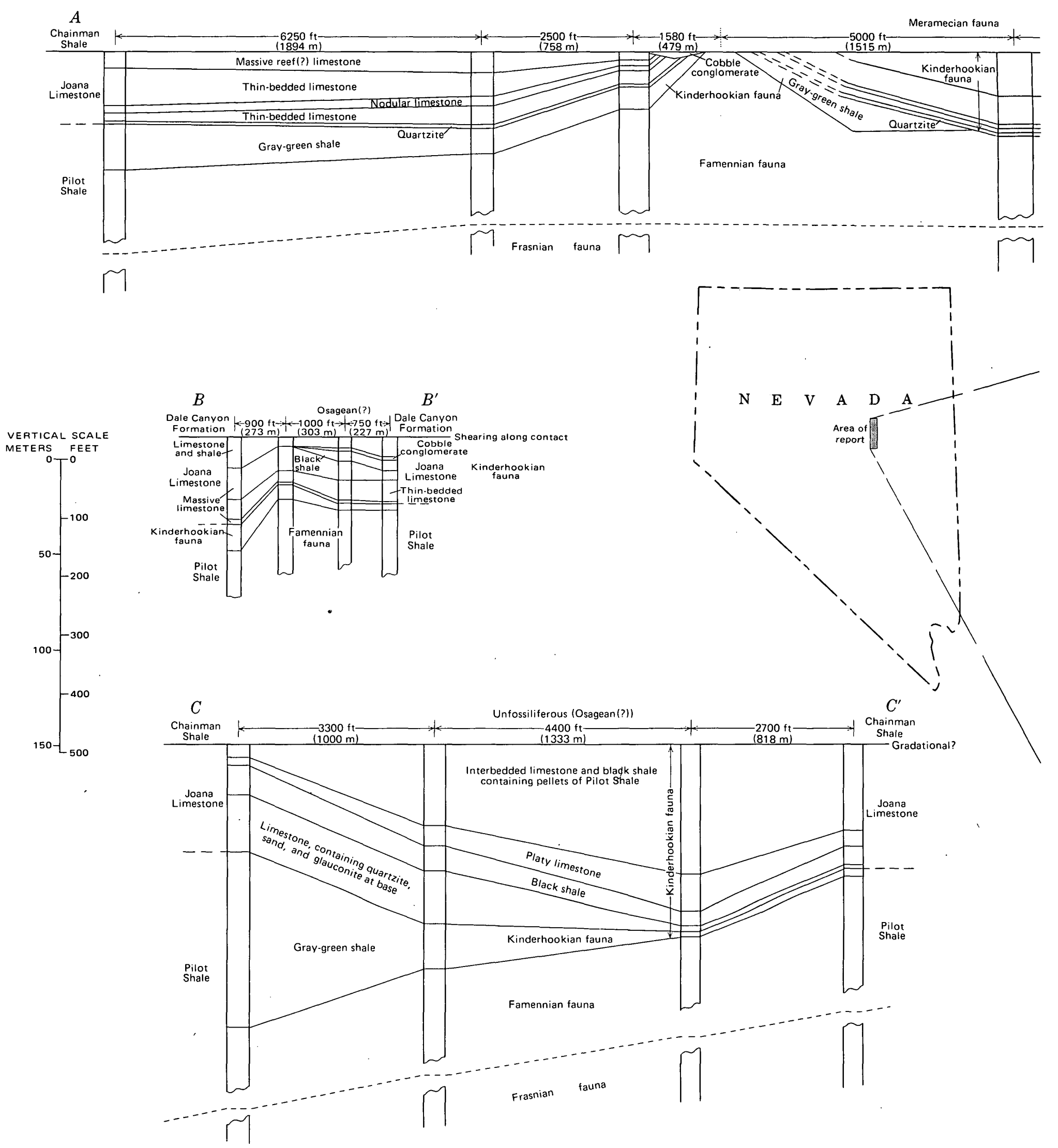

Figure 1.- Report area and sections showing Upper Devonian-Lower Mississippian stratigraphic 
$A^{\prime}$ Shale Unconformity Joana (Kinderhookian Limestone fauna)
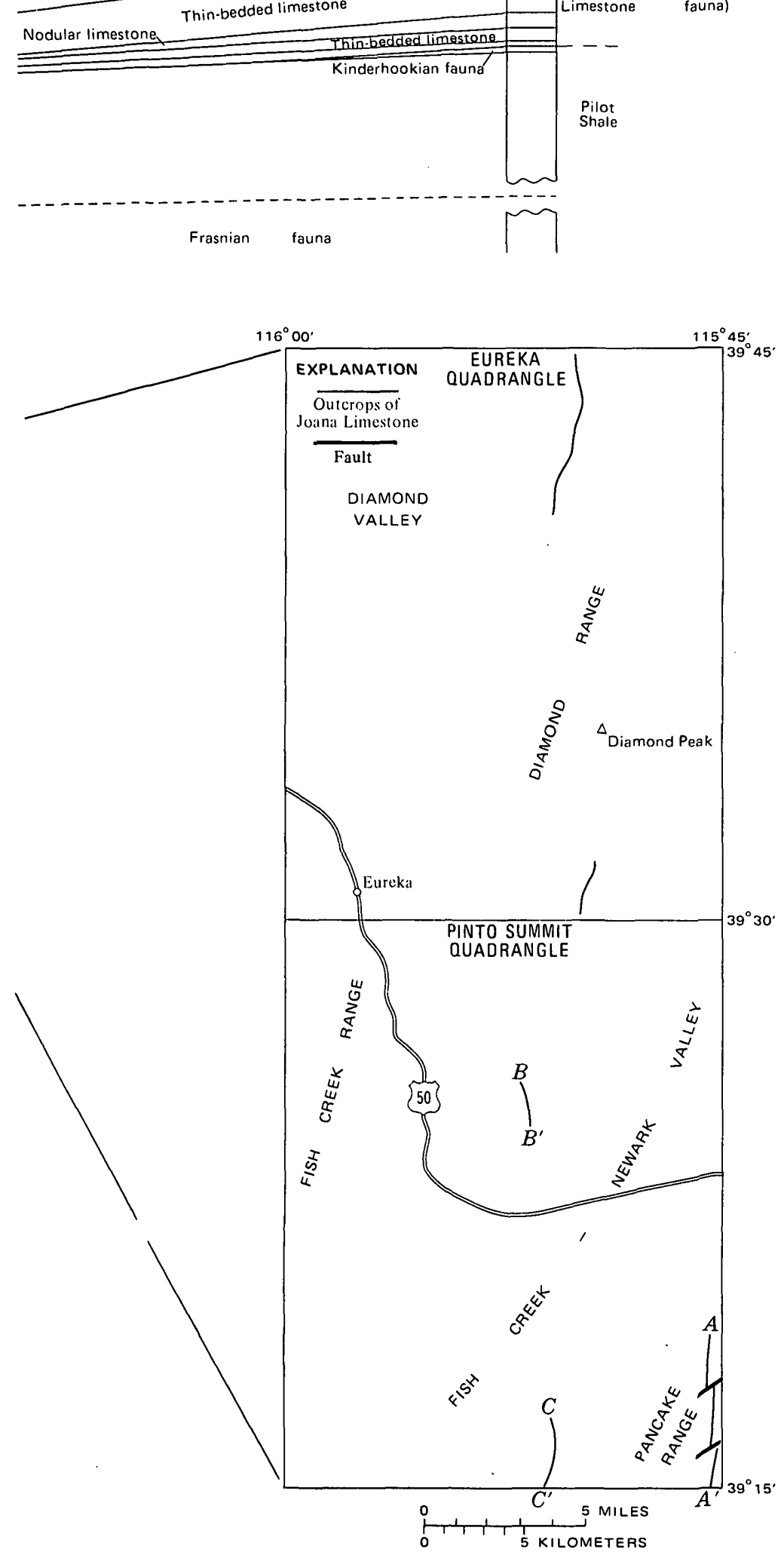

scquences in the Eureka area, Nevada.
Three of these ( $C-C^{\prime}$ of fig. 1 and two to the north in the Diamond Range) are within antiforms; they are parts of thrust plates that are structurally lower than the thrust plates in the synforms.

These lower thrust plates have been beveled during folding by the higher thrust plates. As the thrusting was from west to east, the lower thrust plates are not only older, but the rocks included within them must originally have been deposited some distance east of the rock units within the structurally higher plates in the synforms. The band of outcrops in $B-B^{\prime}$ of figure 1 is within such a synform; $A-A^{\prime}$ is thought to be similarly located, although its occurrence at the eastern edge of the mapped areas leaves some doubt as to its proper assignment to the synform present just to the west.

Each band has one or more discontinuities. Some apparently are simply breaks in sedimentation, but at least three are clearly erosional unconformities, although none shows significant angular discordance.

Sequence $C-C^{\prime}$, which, from its lithology, is believed to have been originally most distant from the outcrop area of the Roberts Mountains thrust, contains two discontinuities in the Pilot Shale. The lower is between the two members of the Pilot that have been distinguished here. Below it are thinbedded shaly limestones containing an abundant Frasnian (early Late Devonian) fauna; above, are yellow-weathering limy shales containing conodonts of Famennian (late Late Devonian) Age. The second disconformity, within the upper member of the Pilot, is between the yellow-weathering Famennian shale and poorly exposed gray-green shale that contains a Kinderhookian (Early Mississippian) conodont fauna.

The gray-green shale of the upper member of the Pilot has a notably variable thickness in this band and is overlain unconformably by the basal unit of the Joana Limestone, which here is characterized by thin pink quartzites and a local bed of glauconite, as well as by thin-bedded limestone. Kinderhookian conodonts are fairly abundant in the limy beds. This stratigraphic break is clearly erosional and must represent a significant episode of disturbance during Kinderhookian time. The gray-green shale, which ranges in thickness from 8 to nearly $300 \mathrm{ft}(2.4-90 \mathrm{~m})$, may represent the reworked weathering product of the Famennian shale which it overlies. Additional evidence of an erosional break at this horizon is the occurrence, in both the lowermost and uppermost units of the Joana, of pellets of the yellowweathering limy shale of the Pilot that contain Famennian fossils.

Sequence $C-C^{\prime}$ shows no physical evidence of an unconformity above the Joana Limestone. In fact, a persistent black shale unit near the base of the Joana here is lithologically similar to the black shales of the overlying Chainman, and the contact of the Joana with the Chainman is apparently gradational. No fossils, however, have been found here in the lower beds of the Chainman, although a gradational contact 
suggests the same relationships as found in Pine Valley, north of Eureka, where Smith and Ketner (1968, p. 14) and Gordon and Duncan (1961, p. C233-C234) reported apparently continuous sedimentation from beds of Kinderhookian age to those of Osagean age.

Sequence $A-A^{\prime}$, in the synform $5 \mathrm{mi}(8 \mathrm{~km})$ east of $C-C^{\prime}$, differs materially from $C-C^{\prime}$ in ways that appear to confirm the assumed originally more western location of $C-C^{\prime}$.

The Pilot Shale in this sequence crops out in large part just east of the Pinto Summit quadrangle; it is significantly thicker than in sequence $C-C^{\prime}$, and the lithologic difference between the two lower members, though recognizable, is not nearly as distinct. The uppermost gray-green shale unit of Kinderhookian age is present locally but is significantly thinner and is absent over considerable distances beneath the Joana.

The local absence of this shale and the occurrence of a thin pink quartzite at the base of the Joana indicate a break in sedimentation, presumably accompanied by erosion, at the Pilot-Joana contact; fossils of Kinderhookian age, however, occur both above and below the contact.

The individual beds of the Joana in $A-A^{\prime}$ are notably different from those in $C-C^{\prime}$, except for the thin basal quartzite. The most striking unit is a massive reef limestone that has a maximum exposed thickness of nearly $100 \mathrm{ft}$ $(30.4 \mathrm{~m})$. A persistent nodular limestone and thin limestone beds with black chert are also distinctive. Furthermore, no beds of Chainman-like black shale, or dense light-gray limestone, such as are found in $C-C^{\prime}$, were recognized.

Most striking, however, is the local occurrence of a coarse cobble conglomerate at the top of the Joana that cuts out the reef limestone, as well as lower Joana beds, and itself is unconformably overlain by typical Chainman Shale.

All the units of the Joana in this sequence contain an abundant Kinderhookian fauna. A short distance above the unconformity, however, Mackenzie Gordon, Jr., collected the cephalopod, Rayonnoceras aff. $R$. protentum Gordon, of Late Mississippian (Meramecian) age. Here, therefore, beds of Osagean age, found to the east high in the type Joana of the Ely region, or to the north in Pine Valley in beds mapped by Smith and Ketner (1968) as Chainman, have been removed by erosion.

Sequence $B-B^{\prime}$, which occurs in Packer Basin, about $10 \mathrm{mi}$ $(16 \mathrm{~km})$ north of $A-A^{\prime}$ and $C-C^{\prime}$, is believed to be in the same synform as $A-A^{\prime}$, but in a different thrust sheet, apparently derived from a region still farther west and thus intermediate in original geographic location between sections $A-A^{\prime}$ and $C-C^{\prime}$. This appears to be confirmed by the rock units exposed and their mutual relationships.

Because of proximity to the fault zone that borders the synform on the west, the Pilot Shale is disturbed and poorly exposed, and the two members are hard to recognize. The uppermost gray-green shale unit, however, is present and ranges in thickness from 7 to $45 \mathrm{ft}(2.1-13.7 \mathrm{~m})$.
This range in thickness, combined with the fact that pellets of yellow silt from the limy shales of the underlying member of the Pilot occur throughout the Joana, indicates that here too there must be an erosional break between the Pilot and the Joana. The pink quartzite that elsewhere marks the base of the Joana is absent; its place appears to be taken by a persistent thin crystalline limestone of about the same thickness.

'i'he Packer Basin sequence $\left(B-B^{\prime}\right)$ resembles sequence $C-C^{\prime}$ in the presence of interlayered black Chainman-type shales and a possible gradational contact with the overlying formation, which is here the Dale Canyon Formation of possible Osagean age (Nolan and others, 1974). The dense gray limestone unit of sequence $C-C^{\prime}$ is, however, absent.

As in sequence $A-A^{\prime}$, a coarse cobble conglomerate occurs in the Joana but is here found within, rather than at the top of, the Joana. It appears, nevertheless, to mark an erosional interval, as to the south it cuts out a black shale unit that to the north is nearly $20 \mathrm{ft}(6 \mathrm{~m})$ thick.

Because of strike faults it is uncertain whether a disconformity is present between the interlayered black shales and limestones of the uppermost Joana and the main mass of the overlying Dale Canyon.

There are thus at least three erosional unconformities shown by these three outcrop bands. Except for the one at the top of the Joana in sequence $A-A^{\prime}$, the time gaps are small, and angular discordance is slight. Furthermore, an even greater number of lithologic disconformities indicates abrupt changes in the conditions of sedimentation. All these disconformities, however, are close to the time interval (Late Devonian-Early Mississippian) reported by Smith and Ketner (1968) as dating the Roberts Mountains thrust in the Pine Valley area, although somewhat extending the range to early Late Devonian time at one extreme and late Early Mississippian on the other. They therefore suggest that the major period of movement along the Roberts Mountains thrust in the Pine Valley region was marked here at Eureka by several episodes of orogeny, which individually, to judge by the relatively slight indication of discordance in the sedimentary section, were of rather modest proportions in comparison with the total movement along the thrust.

Similar detailed stratigraphic evidence was not obtained in the Eureka district for such episodic deformation over the longer period-Late Devonian to Early Pennsylvanian-reported by Roberts, Hotz, Gilluly, and Ferguson (1958); published descriptions of sections of middle and upper Paleozoic rocks in central and eastern Nevada, however, suggest that detailed study might indicate that such episodic disturbances also characterized this longer time interval. At Eureka, for example, an unconformity at the Silurian-Devonian contact (Nolan and others, 1956, p. 38) and at least three thick, though local, sandstone members in the Devonian carbonate section suggests structural disturbances prior to Kinderhookian time. Similarly, the thick Chainman-Diamond Peak sequence of Late Mississippian age includes many thick conglomerates, 
fossil-plant-bearing sandstones, and striking interfingering of Ienticular clastic beds. This, as noted by Gilluly and Gates, (1965), may indicate similar activity in post-Kinderhookian time.

Roberts (1972, p. 1997), who has studied the Roberts Mountains thrust over a wide area, reported that he considers that the Antler orogeny, during which the thrust was active, extended from Late Devonian through Middle Pennsylvanian time-an even longer interval.

The Eureka area supports this extension into the Pennsylvanian in that the Lower and Middle Pennsylvanian limestone, which is found locally, is overlain unconformably by Lower Permian (Wolfcampian) sedimentary rocks (Nolan and others, 1956 , p. 62-63). In several sequences the unconformity has completely removed the Pennsylvanian rocks, and Wolfcampian sandy limestones rest directly on different horizons of the Diamond Peak.

Orogeny during this longer period, in the light of the above discussion, implies that movement along the Roberts Mountains thrust probably occurred at different times in different places or, equally probable, that in many places it was recurrent and episodic.

The time involved is a long one, as the interval from Middle Devonian to Middle Pennsylvanian is about $50 \mathrm{~m} . \mathrm{y}$. (Harland and others, 1964, p. 262). The total movement along the thrust has been estimated to be at least $60 \mathrm{mi}$ (approximately $100 \mathrm{~km}$ ), which means an average rate (for this episodic crustal shortening in the central Nevada area) of about $1 \mathrm{~cm} / 5 \mathrm{yr}$. This accords fairly well with the rates of movement within orogenic belts cited by Sutton (1969, p. 247-248).

An additional implication of this extended time during which the Antler orogeny was active would seem to lead to a reappraisal of the basis for the several orogenies that have been described in recent years as occurring in the central and eastern Great Basin (Armstrong, 1968; Roberts, 1972; Coats and Gordon, 1972).

The Sonoma orogeny of Silberling and Roberts $(1962$, p. 36) has been assigned to the Late Permian or Early Triassic, although Speed (1971) suggested that it be restricted to the Early Triassic. At Eureka, however, Wolfcampian (Lower Permian) limestones are succeeded conformably by a thick series. of coarse conglomerates which suggest that this deformation began somewhat earlier.

Gilluly and Gates (1965, p. 123-125) described the Lewis orogeny from an area northwest of Eureka as being of post-Middle Triassic and pre-Eocene age; it seemingly began before the Nevadan orogeny, generally thought to be of Middle to Late Jurassic age. These orogenies are followed closely by Armstrong's (1968) Sevier orogeny of Cretaceous age, which in turn is distinguished from the Laramide orogeny, which he assigned to the Late Cretaceous and Eocene.

Different authors have assigned somewhat aifferent ranges to each of these events, in part at least, reflecting different areas of study, and to this extent they are in agreement with the conclusions reached above on the Antler orogeny. These longer periods of time assigned to each orogeny, however, result either in overlaps in the times of activity or in so shortening the intervals between the orogenies that each of the intervals is less than the overall length of each orogenic period.

This accumulating body of evidence seems to indicate that rather than several discrete and areally separated orogenies, these are all episodes that overlap both areally and temporally in a single long-continued period of deformation of the Earth's crust (Nolan, 1943, p. 177-178; Armstrong, 1968 p. 451; Roberts, 1972, p. 2000).

If the concept of a single mountain-building period is valid, it is tempting to extend the suggested rate of movement, derived above for the Roberts Mountains thrust, to the whole interval from Middle Devonian time to the present. This would indicate a minimum shortening of some 400 to $500 \mathrm{mi}$ $(640-800 \mathrm{~km})$, a figure that the increasingly detailed knowledge of the structure and stratigraphy of the Great Basin appears to render not unreasonable.

It is also suggestive to compare this rate of shortening with the recent estimates of sea-floor spreading. Even though the proposed rate of shortening in Middle Paleozoic time is quite speculative, it is nevertheless worth noting that both it and the rate of sea-floor spreading are measured in centimeters per year. This may well indicate a common mechanism for both movements; any mechanism affecting as large a part of the globe as the oceans should also affect the adjoining continents.

Still further extension of this speculation leads to the likelihood that such a mechanism has been operative over much, if not all, of geologic time, although small variations in rate may have occurred.

\section{ACKNOWLEDGMENTS}

C. W. Merriam and Mackenzie Gordon, Jr., made significant contributions both in the field and in the office through their detailed knowledge of the faunas of the Devonian (Merriam) and Mississippian (Gordon); J. W. Huddle's familiarity with the conodont faunules of both systems has been particularly helpful. M. Clark Blake, Jr., and George Cone participated in the fieldwork, and Blake and James Gilluly, as well as Merriam, Gordon, and Huddle reviewed the manuscript.

\section{REFERENCES CITED}

Armstrong, R. L., 1968, Sevier orogenic belt in Nevada and Utah: Geol. Soc. America Bull., v. 79, no. 4, p. 429-458.

Coats, R. R., and Gordon, Mackenzie, Jr., 1972, Tectonic implications of the presence of the Edna Mountain Formation in northern Elko County, Nevada, in Geological Survey research 1972: U.S. Geol. Survey Prof. Paper 800-C, p. C85-C94.

Gilluly, James, and Gates, Olcott, 1965, Tectonic and igneous geology of the northern Shoshone Range, Nevada: U.S. Geol. Survey Prof. Paper 465, $153 \mathrm{p}$. 
Gordon, Mackenzie, Jr., and Duncan, Helen, 1961, Early Mississippian faunas in southwestern Elko County, Nevada, in Short papers in the geologic and hydrologic sciences: U.S. Geol. Survey Prof. Paper 424-C, p. C233-C234.

Harland, W. B., Smith, A. G., and Wilcock, Bruce, 1964, The Phanerozoic time scale; a symposium: Geol. Soc. London Quart. Jour., v. 120 Supp., 458 p.

Merriam, C. W., 1963, Paleozoic rocks of Antelope Valley, Eureka and Nye Counties, Nevada: U.S. Geol. Survey Prof. Paper 423, 67 p.

Merriam, C. W., and Anderson, C. A., 1942, Reconnaissance survey of the Roberts Mountains, Nevada: Geol. Soc. America Bull., v. 53, no. 12, pt. 1, p. 1675-1727.

Nolan, T. B., 1943, The Basin and Range province in Utah, Nevada, and California: U.S. Geol. Survey Prof. Paper 197-D, p. 141-196.

Nolan, T. B., Merriam, C. W., and Blake, M. C., Jr., 1974, Geologic map of the Pinto Summit quadrangle, Eureka and White Pine Counties Nevada: U.S. Geol. Survey Misc. Geol. Inv. Map I-793. (In press.)

Nolan, T. B., Merriam, C. W., and Williams, J. S., 1956, The stratigraphic section in the vicinity of Eurcka, Nevada: U.S. Geol. Survey Prof. Paper 276, 77 p.

Roberts, R. J., 1972, Evolution of the Cordillera fold belt: Geol. Soc. America Bull., v. 83, no. 7, p. 1989-2004.

Roberts, R. J., Hotz, P. E., Jr., Gilluly, James, and Ferguson, H. G. 1958, Paleozoic rocks of north-central Nevada: Am. Assoc. Petroleum Geologists Bull., v. 42, no. 12, p. 2813-2857.

Silberling, N. J., and Roberts, R. J., 1962, Pre-Tertiary stratigraphy and structure of northwestern Nevada: Geol. Soc. America Spec. Paper $72,58 \mathrm{p}$.

Smith, J. F., Jr., and Ketner, K. B., 1968, Devonian and Mississippian rocks and the date of the Roberts Mountains thrust in the - Carlin-Pinon Range arca, Nevada: U.S. Geol. Survey Bull. 125l-I, $18 \mathrm{p}$.

Speed, R. C., 1971, Golconda thrust, western Nevada-regional extent: Geol. Soc. America Abs. with Programs, v. 3, no. 2, p. 199-200.

Sutton, John, 1969, Rates of change within orogenic belts, in Kent, P. E., and others, eds., Time and place in orogeny: Geol. Soc. London Spec. Pub. 3, p. 239-250. 


\title{
FOLDS AND OVERTHRUSTS OF LATE JURASSIC OR EARLY CRETACEOUS AGE IN NORTHERN NEVADA
}

\author{
By KEITH B. KETNER and J. FRED SMITH, JR., Denver, Colo.
}

\begin{abstract}
The partly isoclinal, partly overturned Adobe syncline extends for at least $75 \mathrm{mi}$ northeastward across the northern Cortez Mountains, the northern Pinon Range, and along the entire length of the Adobe Range. The folded rocks range in age from Ordovician through Jurassic and may include some rocks of Cretaceous age. This syncline is flanked by anticlines in the central and southern parts of the Pinon Range and in the southern Independence Mountains. In places the Adobe syncline is discordantly overlain by nearly flat-lying thrust plates composed of Ordovician, Devonian, Mississippian, and Permian rocks. The geometric relations indicate that these thrust plates moved at least $6 \mathrm{mi}$, but postfold thrust movement was not great, because the Mississippian and Permian rocks of the thrust plates closely resemble correlative autochthonous rocks nearby. The Ordovician and Devonian rocks have been thrust to their present position in at least two stages; the earlier movement or movements took place long before folding of the Adobe syncline and the later movement immediately afterward. The folding and last stage of thrusting were in Late Jurassic or Early Cretaceous time.
\end{abstract}

Rocks exposed in the Cortez Mountains, Pinon Range, and Adobe Range (fig. 1) were strongly deformed at least three times before Late Cretaceous time. The first known major disturbance was one in which Ordovician to Devonian eugeosynclinal rocks were thrust over correlative miogeosynclinal rocks. It took place in latest Devonian or earliest Mississippian time (Smith and Ketner, 1968). In a second distinctly later disturbance Paleozoic eugeosynclinal rocks were thrust over Mississippian detrital deposits that had been formed after, and as a result of, the earlier disturbance (Kerr, 1962; Ketner, 1970a,b; Evans and Ketner, 1971). On the basis of the following evidence this second disturbance began in Middle Pennsylvanian and ended before Late Permian time. In the area of this report deposition was continuous from Early Mississippian to Middle Pennsylvanian time; after a widespread interruption, deposition resumed locally in Late Pennsylvanian to Late Permian time; and a thrust fault involving Mississippian rocks in the Adobe Range was overlapped depositionally by Upper Permian rocks. In a third disturbance autochthonous rocks were intensely folded, and Paleozoic rocks were thrust over upturned beds as young as Early Triassic. The extent and age of the folding and thrust faulting in the last of these deformations are the subjects of this report.

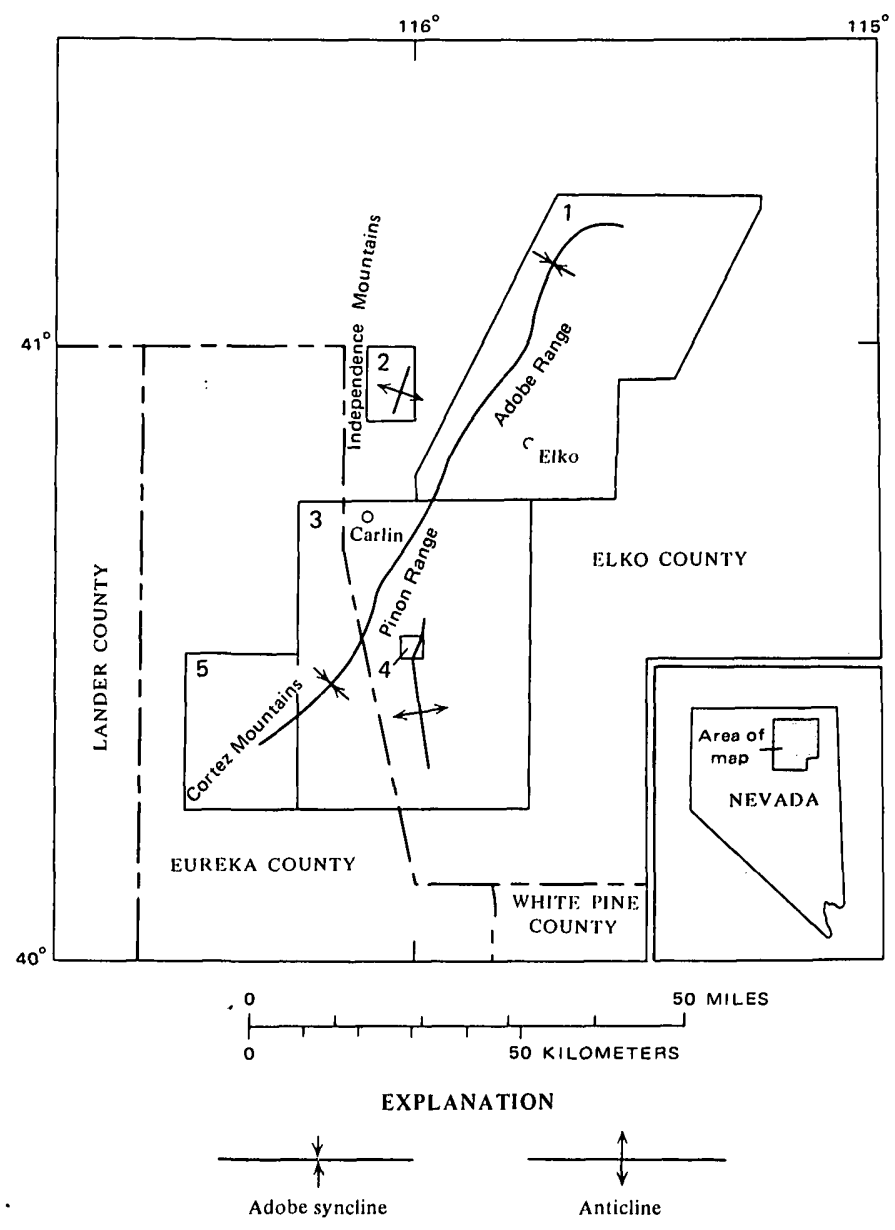

Figure 1.-Index map of part of northern Nevada showing mapped areas, the axis of the Adobe syncline, and axes of flanking anticlines. Geologic map areas: 1, Ketner (1970a); 2, Evans and Ketner (1971); 3, Smith and Ketner (1972); 4, Ketner and Smith (1963); 5, Muffler (1964).

We gratefully acknowledge the help of a large number of geologists who assisted us in mapping and who supplied indispensable aid in dating the map units. The contribution of R. L. Armstrong, who dated the Frenchie Creek Rhyolite radiometrically, is especially useful. 


\section{ADOBE SYNCLINE}

A partly isoclinal, partly overturned syncline, herein called the Adobe syncline, extends for at least $75 \mathrm{mi}$ northeastward across the northern Cortez Mountains, the northern Pinon Range, and along the entire length of the Adobe Range. It is best developed and best exposed in the northern part of the Adobe Range. There the Chainman Shale is overlain with slight angular discordance by a conformable sequence of unnamed marine Permian and Lower Triassic beds (table 1). All these units are folded in a northeast- and east-trending syncline whose northwest limb is vertical or slightly overturned and whose southeast limb dips $40^{\circ}-65^{\circ} \mathrm{NW}$. Triassic beds in the very center of the syncline are isoclinally folded and are generally nearly vertical. Farther south in the Adobe Range the syncline is more open and, although the Chainman Shale is concealed and Permian and Triassic units are absent, the synclinal form is expressed by the attitudes of bedding within the Diamond Peak Formation. At the extreme southern end of the range the synclinal form is expressed by bedding in the Diamond Peak Formation and in the Strathearn Formation of Dott (1955) and younger Permian beds which overlie the Diamond Peak.

In the northern Pinon Range the Adobe syncline is a little less distinct than in the Adobe Range because it is much broader and more complicated by minor folds and high-angle faults and because the trend of the axis is irregular. However, the attitudes within the Webb and Chainman Formations and the general spatial arrangement of all the upper Paleozoic units unmistakably define a syncline whose axis is alined with that in the Adobe Range.

In the northern Cortez Mountains the southeast linb of the syncline is clearly defined by bedding in the Big Pole Formation (Muffler, 1964, pl. 1). In the Big Pole Formation the beds that form the southeast limb now dip an average of about $50^{\circ} \mathrm{NW}$. However, unlike the Adobe and Pinon Ranges, the Cortez Mountains were tilted to the east in late Cenozoic time, as can be seen by the steep west-facing scarp and gently sloping eastern face. Restoration of the Cortez Mountains to the pretilt attitude, therefore, would tend to steepen the bedding in the Big Pole Formation to an average of $60^{\circ}$ or more. This attitude is too steep to be confused with initial dip and too consistent to be confused with drag folds or deformation along intrusive contacts. The northwest limb of the syncline is not clearly defined in the Cortez Mountains because the area where southeast-dipping beds of the Big Pole could be expected to crop out is occupied by intrusive rocks.

Although it seems clear that the Big Pole Formation has been folded as part of the Adobe syncline, it is somewhat less clear that the overlying Sod House Tuff and Frenchie Creek Rhyolite are also involved in the folding. However, the attitude of the contacts between formations and of individual flows and minor folds within the Frenchie Creek is consistent

Table 1.-Strongly folded autochthonous units and formations of the postfold thrust plates

\begin{tabular}{|c|c|c|c|c|}
\hline Geologic age & $\begin{array}{c}\text { Anticline in } \\
\text { Independence } \\
\text { Mountains }\end{array}$ & Adobe syncline & $\begin{array}{l}\text { Anticline } \\
\text { in } \\
\text { Pinon Range }\end{array}$ & $\begin{array}{l}\text { Postfold } \\
\text { thrust plates }\end{array}$ \\
\hline $\begin{array}{l}151 \pm 3 \text { m.y. ago } \\
\text { (Late Jurassic). }\end{array}$ & $\begin{array}{l}\ldots \ldots \ldots \ldots \ldots \\
\ldots \ldots \ldots \ldots \ldots\end{array}$ & $\begin{array}{l}\text { Frenchie Creek Rhyolite } \ldots \ldots \\
\text { Sod House Tuff } \ldots \ldots \ldots \ldots \ldots \\
\text { Big Pole Formation } \ldots \ldots \ldots \ldots\end{array}$ & $\begin{array}{l}\ldots \ldots \ldots \ldots \ldots \ldots \ldots \\
\ldots \ldots \ldots \ldots \ldots \ldots \ldots \ldots\end{array}$ & \\
\hline $\begin{array}{l}\text { Triassic and } \\
\text { Permian. }\end{array}$ & $\ldots \ldots \ldots \ldots$ & $\begin{array}{l}\text { Unnamed shale and } \\
\text { limestone (northern } \\
\text { Adobe Range). }\end{array}$ & $\ldots \ldots \ldots \ldots \ldots$ & \\
\hline Permian ........ & $\ldots \ldots \ldots \ldots$ & $\begin{array}{l}\text { Unnamed siltstone, } \\
\text { sandstone, conglomerate, } \\
\text { limestone, chert (Pinon and } \\
\text { Adobe Ranges). }\end{array}$ & $\begin{array}{l}\text { Unnamed siltstone, } \\
\text { sandstone, conglomerate, } \\
\text { limestone. }\end{array}$ & $\begin{array}{l}\text { Unnamed siltstone, } \\
\text { sandstone, conglomerate, } \\
\text { limestone (Adobe Range). }\end{array}$ \\
\hline $\begin{array}{l}\text { Permian and } \\
\text { Pennsylvanian. }\end{array}$ & $\ldots \ldots \ldots \ldots \ldots$ & $\begin{array}{l}\text { Strathearn Formation } \\
\text { of Dott (1955). }\end{array}$ & $\ldots \ldots \ldots \ldots \ldots$ & \\
\hline $\begin{array}{l}\text { Pennsylvanian and } \\
\text { Mississippian. }\end{array}$ & & Diamond Peak Formation & $\begin{array}{l}\text { Diamond Peak } \\
\text { Formation. }\end{array}$ & \\
\hline Mississippian. ...... & Unnamed limestone . & $\begin{array}{l}\text { Chainman Shale } \ldots \ldots \ldots \ldots \ldots \\
\text { Webb Formation } \ldots \ldots \ldots \ldots\end{array}$ & $\begin{array}{c}\text { Chainman Shale } \ldots \ldots \ldots \ldots \\
\ldots \ldots \ldots \ldots \ldots\end{array}$ & Webb Formation. \\
\hline Devonian ........ & $\ldots \ldots \ldots \ldots$ & $\ldots \ldots \ldots \ldots \ldots \ldots \ldots \ldots$ & $\begin{array}{l}\text { Devils Gate } \\
\text { Limestone. } \\
\text { Nevada Formation . . . . . . . }\end{array}$ & $\begin{array}{l}\text { Woodruff Formation. } \\
\text { Unnamed chert, shale, } \\
\text { limestone (Adobe Range). }\end{array}$ \\
\hline $\begin{array}{l}\text { Devonian and } \\
\text { Silurian. }\end{array}$ & $\begin{array}{l}\text { Roberts Mountains } \\
\text { Formation. }\end{array}$ & $\ldots \ldots \ldots \ldots \ldots \ldots \ldots$ & $\ldots \ldots \ldots \ldots \ldots \ldots$ & \\
\hline Silurian $\ldots \ldots \ldots$ & $\ldots \ldots \ldots \ldots$ & $\ldots \ldots \ldots \ldots \ldots \ldots \ldots$ & $\begin{array}{l}\text { Lone Mountain } \\
\text { Dolomite. }\end{array}$ & \\
\hline Ordovician ....... & $\ldots \ldots \ldots \ldots \ldots$ & $\ldots \ldots \ldots \ldots \ldots \ldots$ & $\begin{array}{l}\text { Hanson Creek } \\
\quad \text { Formation. } \\
\text { Eureka Quartzite } \ldots \ldots \ldots \ldots \\
\text { Pogonip Group } \ldots \ldots \ldots \ldots\end{array}$ & $\begin{array}{l}\text { Unnamed shale and } \\
\text { chert (Adobe Range). }\end{array}$ \\
\hline
\end{tabular}


with the attitude of the Big Pole, indicating that the Frenchie Creek was folded with the Big Pole.

The age of the Frenchie Creek Rhyolite, based on a radiometric determination by $R$. L. Armstrong (vritten commun. to L. J. P. Muffler, 1972), is $151 \pm 3$ m.y. (Late Jurassic according to Harland and others, 1964).

\section{POSSIBLY ASSOCIATED ANTICLINES}

A well-developed major anticline, partly parallel with the Adobe syncline, passes through the central and southern parts of the Pinon Range (Ketner and Smith, 1963; Smith and Ketner, 1972). This anticline cannot be traced in either direction from the Pinon Range because of incomplete exposures and intense high-angle faulting. In one area, the west limb of this anticline is steeper than the east limb, and it is locally overturned to the west.

A short segment of another anticline nearly parallel with the Adobe syncline is exposed in the southern Independence Mountains (Evans and Ketner, 1971). Although this anticline can be traced only $3 \mathrm{mi}$ owing to inadequate exposures, the attitude of beds $12 \mathrm{mi}$ farther north in the Independence Mountains (Lovejoy, 1959) suggests that the axis of the anticline may be concealed by Tertiary rocks just east of the range. Both anticlines expose windows in Paleozoic thrust plates, and both are the loci of Tertiary granitic stocks and associated mineral deposits.

\section{POSTFOLD THRUST PLATES}

In two areas, the northern Adobe Range and the northern Pinon Range, nearly flat-lying thrust plates lie discordantly across the folded rocks of the Adobe syncline. In the Adobe Range, the plates are composed of Ordovician and Devonian chert and shale derived from distant eugeosynclinal depositional sites and of Permian detrital rocks of local origin.

In the northern Pinon Range a single thrust plate at least 5 mi wide lies squarely across the axial part of the syncline. It is composed of chert and shale of the Devonian Woodruff Formation overlain unconformably by siltstone of the Mississippian Webb Formation. The Woodruff Formation was derived from a distant eugeosynclinal depositional site, but the Webb Formation is of local origin.

Geometric relations of the thrust plates to folded beds of the Adobe syncline indicate movement on the thrust faults of as much as $6 \mathrm{mi}$, and facies relations indicate that movement on the postfold thrust faults probably did not greatly exceed that amount. In the region covered by this report, facies changes in Mississippian and Permian rocks tend to be rather abrupt. Despite this, the rocks of these ages above and below the postfold thrust faults are lithologically very similar, indicating that transport on the thrusts was not very great. In contrast, facies changes in Ordovician and Devonian rocks tend to be very gradual. Despite this, rocks of these ages above and below the thrust faults are lithologically very dissimilar. Apparently the Ordovician and Devonian rocks were moved into the local area during a former episode or episodes of thrusting before being carried with the younger rocks on thrust faults of the postfold generation.

\section{AGE OF FOLDING AND THRUSTING}

The Adobe syncline was formed after eruption of the Frenchie Creek Rhyolite 151 m.y. ago (Late Jurassic) and before deposition of lower Tertiary beds which lie with a strong unconformity across the folded beds of the Chainman Shale in the northern Adobe Range. Thick conglomeratic beds of Cretaceous age overlie the folded rocks in the Cortez Mountains. It is not entirely clear whether these rocks have been folded with the Adobe syncline or were deposited during or after the syncline was formed, but the evidence favors postfolding deposition. Many clasts in the Cretaceous beds were derived from Paleozoic rocks which were probably exposed to erosion by the folding process. Because these conglomeratic rocks are of late Early Cretaceous and Late Cretaceous age, the folding and associated thrust faulting must have taken place in Late Jurassic or Early Cretaceous time.

\section{REFERENCES CITED}

Dott, R. H., Jr., 1955, Pennsylvanian stratigraphy of Elko and northern Diamond Ranges, northeastern Nevada: Am. Assoc. Petroleum Geologists Bull., v. 39, no. 11, p. 2211-2305.

Evans, J. G., and Ketner, K. B., 1.971, Geologic map of the Swales Mountain quadrangle and part of the Adobe Summit quadrangle, Elko County, Nevada: U.S. Geol. Survey Misc. Geol. Inv. Map I-667.

Harland, W. B., Smith, A. G., and Wilcock, Bruce, eds., 1964, The Phanerozoic time-scale-A symposium dedicated to Professor Arthur Holmes: Geol. Soc. London Quart. Jour., supp., v. 120s, $458 \mathrm{p}$.

Kerr, J. W., 1962, Palcozoic sequences and thrust slices of the Seetoya Mountains, Independence Range, Elko County, Nevada: Geol. Soc. America Bull., v. 73, no. 4, p. 439-460.

Ketner, K. B., 1970a, Geology and mineral potential of the Adobe Range, Elko Hills, and adjacent areas, Elko County, Nevada, in Geological Survey research 1970: U.S. Geol. Survey Prof. Paper 700-B, p. B105-B108.

$1970 \mathrm{~b}$, Limestone, turbidite of Kinderhook age and its tectonic significance, Elko County, Nevada, in Geological Survey research 1970: U.S. Geol. Survey Prof. Paper 700-D, p. D18-D22.

Ketner, K. B., and Smith, J. F., Jr., 1963, Geology of the Railroad mining district, Elko County, Nevada: U.S. Geol. Survey Bull. 1162-B, 27 p.

Lovejoy, D. W., 1959, Overthrust Ordovician and the Nannie's Peak intrusive, Lone Mountain, Elko County, Nevada: Geol. Soc. America Bull., v. 70, no. 5, p. 539-564.

Muffler, L. J. P., 1964, Geology of the Frenchie Creek quadrangle, north-central Nevada: U.S. Geol. Survey Bull. 1179, 99 p.

Smith, J. F., Jr., and Ketner, K. B., 1968, Devonian and Mississippian rocks and the date of the Roberts Mountains thrust in the Carlin-Pinon Range area, Nevada: U.S. Geol. Survey Bull. 1251-I, $18 \mathrm{p}$.

1972, Generalized geologic map of the Carlin, Dixie Flats, Pine Valley, and Robinson Mountain quadrangles, Elko and Eureka Counties, Nevada: U.S. Geol, survey Misc. Field Studies Map MF-481. 



\title{
SHALLOW SEISMIC COMPRESSIONAL AND SHEAR WAVE REFRACTION AND ELECTRICAL RESISTIVITY INVESTIGATIONS AT ROCKY FLATS, JEFFERSON COUNTY, COLORADO
}

\author{
By HANS D. ACKERMANN, Denver, Colo.
}

\begin{abstract}
Seismic refraction and electrical resistivity investigations at Rocky Flats, Colo., a gravel-capped pediment, indicated an irregular bedrock surface which ranges in depth from 3 to $27 \mathrm{~m} \mathrm{(10-90} \mathrm{ft})$. Layers within the gravel that were revealed by interpretation of seismic and electrical data do not correlate, but the combining of results reveals information about water saturation and elastic properties of the overburden. Velocity variations within bedrock affect depth calculations.
\end{abstract}

Shallow seismic refraction and electrical resistivity measurements were made at Rocky Flats, Colo., in September 1970 and May 1972. The purpose of the investigation was to delineate the bedrock surface and to determine properties of the overlying gravel cap, particularly as they relate to the channeling of ground water.

Velocity variations observed within bedrock and their effect on seismic depth calculations were also studied.

Rocky Flats is a pediment, capped by a Pleistocene gravel named Rocky Flats Alluvium (Scott, 1960). It is about $25 \mathrm{~km}$ (16 mi) northwest of Denver, Colo., at the foot of the Front Range uplift; it occupies much of the southwest part of the Louisville $7 \frac{1}{2}$-min quadrangle and lesser parts of the adjoining Golden, Ralston Buttes, and Eldorado Springs quadrangles. The site of the geophysical measurements is midway between Boulder and Golden, Colo., just east of State Highway 93 and about $2 \frac{1}{2} \mathrm{~km}\left(1 \frac{1}{2} \mathrm{mi}\right)$ southwest of the Dow Chemical Rocky Flats plant (fig. 1).

Malde (1955, p. 223) described the gravel cap ranges in thickness from less than 1 to about $15 \mathrm{~m}$; the thinnest parts are over bedrock ridges and the thickest are over broad shallow channels. The top of the gravel cap is smooth. The chief gravel constituent is quartzite, much of it pebble size though boulders as large as $1 / 2 \mathrm{~m}$ are common.

Bedrock geology, pertinent to the geophysical work, is excerpted from Spencer (1961) and Van Horn (1957). The formations involved are of Cretaceous age. In order of decreasing age (west to east) they are the Pierre Shale, the Fox Hills Sandstone, and the Laramie and Arapahoe Formations.

The Pierre Shale is of marine origin, about 2,400 $\mathrm{m}(8,000$ $\mathrm{ft}$ ) thick, and generally homogeneous. It is lead gray to brown and black, and weathers to olive gray or brown. The Pierre
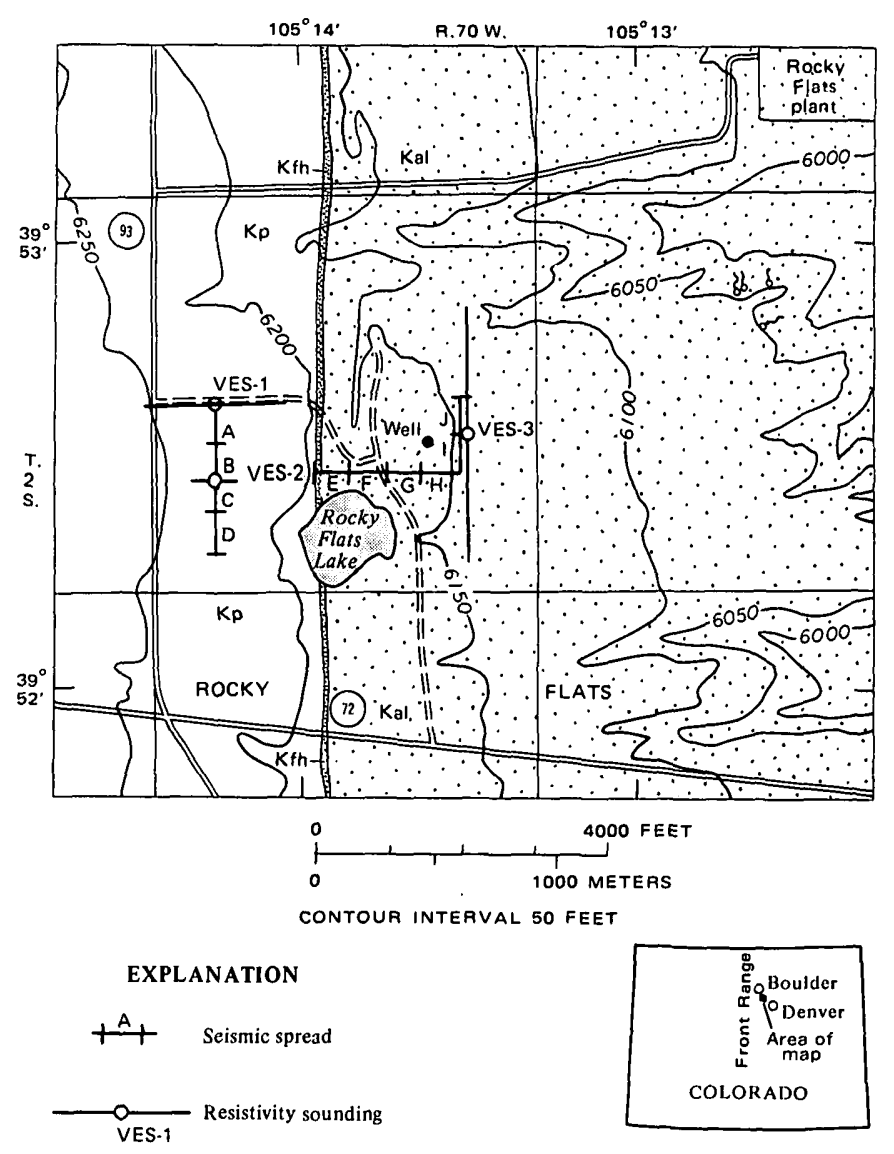

Figure 1.-Map showing location of geophysical measurements at Rocky Flats, Jefferson County, Colorado, and bedrock geology: Kal, Arapahoe and Laramie Formations; Kfh, Fox Hills Sandstone; and $\mathrm{Kp}$, Pierre Shale; all Late Cretaceous in age. Bcdrock gcology from Spencer (1.961) and Van Horn (1957); base from U.S. Geological Survey Louisville and Golden $7 \frac{1}{2}$-min topographic quadrangle maps.

contains minor amounts of siltstone, silty sandstone, and limestone.

The Fox Hills Sandstone is about $18 \mathrm{~m}(60 \mathrm{ft})$ thick and is composed predominantly of nonresistant, fine-grained quartz sandstone. 
The Laramie Formation is of brackish- and fresh-water origin and consists of two parts. The lower part, about $30 \mathrm{~m}$ (100 ft) thick, is chiefly sandstone and sandy shale interbedded with lesser amounts of claystone, shale, and coal. The upper part, about $180-210 \mathrm{~m}(600-700 \mathrm{ft})$ thick, is chiefly clay shale and sandy shale. The map unit includes the Arapahoe Formation in its upper part.

Because of the different geologic formations traversed, the measurement locations are described here in terms of the underlying rock types and their attitude. Seismic spreads A, B, C, and D compose a north-south line (fig. 1) $610 \mathrm{~m}(2,000 \mathrm{ft})$ long parallel to the strike of the Pierre Shale whose dip at this location is nearly vertical. Direct current resistivity depth soundings, VES-1 and VES-2, were taken at the north ends of spreads $A$ and $C$, with electrodes expanded perpendicular to the strike of the Pierre Shale.

Spreads E, F, G, and H compose a 610-m-long (2,000-ft) west-east line perpendicular to the regional strike. They transect successively the upper few hundred feet of the Pierre Shale, the Fox Hills Sandstone, and the lower and upper parts the Laramie Formation. Beds dip steeply beneath spread E, and are nearly horizontal at the east end of spread $H$. A section showing the top of the Fox Hills Sandstone, based on structure contours (Spencer, 1961), is sketched in figure 2.

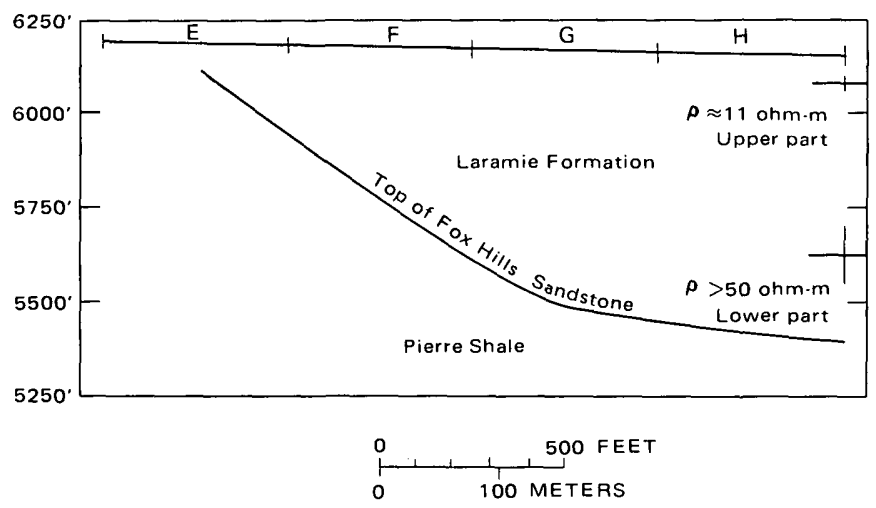

Figure 2.-Approximate horizon representing the top of the Fox Hills Sandstone with respect to spreads E, F, G, and H constructed from structure contours (Spencer 1961). Also shown are resistivities $(\rho)$ within the Laramie Formation interpreted from depth sounding VES-3. Vertical lines are error bars.

Spread F approximately straddled the south edge of a claypit within the Laramie Formation. Its north end was near a portal of the inactive Capital Coal mine.

Spreads I and J compose a south-north line $305 \mathrm{~m}(1,000 \mathrm{ft})$ long. Underlying bedrock is the upper part of the Laramie Formation whose beds at this location are nearly horizontal. An electrical sounding (VES-3) was made at the common shotpoint between spreads I and J. Electrodes were expanded in the direction of the seismic line.

Little information is available on ground water in the area. A water well, drilled "many" years ago about $150 \mathrm{~m}(500 \mathrm{ft})$ north of spread H (fig. 1), penetrated the Laramie Formation at about $24 \mathrm{~m}(80 \mathrm{ft})$ (M. E. Church, oral commun., 1970). It did not yield appreciable amounts of water and was abandoned.

\section{FIELD PROCEDURES}

September 1970.-Seismic spreads were $500 \mathrm{ft}$ long, each consisting of 24 vertical geophones at $20-\mathrm{ft}$ intervals. All spreads except A were recorded with four shots each consisting of $1 / 2-2 \mathrm{lb}$ of gelatin dynamite buried $1 / 2-3 \mathrm{ft}$ deep. Common shotpoints were located $20 \mathrm{ft}$ beyond each end phone. In-line offset shots (spread A excluded) were located 230-300 ft from the ends. Offset distances were determined from the critical bedrock distance estimated from prior shots.

Spread F, because of the complex bedrock configuration beneath it, was also recorded with two shorter spreads using 10-ft geophone spacings. A hammer blow on a steel plate was the energy source. Recording equipment was a standard 24-channel analog exploration seismograph.

Electrical resistivity depth soundings were made using the Schlumberger electrode configuration (Van Nostrand and Cook, 1966, p. 40). VES-1 was expanded $1,000 \mathrm{ft}$ and VES-2, $300 \mathrm{ft}$. VES-3 was expanded 2,000 ft in an attempt to detect the Pierre Shale at a depth of about $800 \mathrm{ft}$.

May 1972.-Horizontally polarized shear waves (SH) were recorded with 150-ft spreads at the north end of spread A and the south end of spread D. Shear energy was generated using linear horizontal traction obtained by striking the end of an 8-ft-long plank, coupled firmly to the ground, with a sledge hammer (Onda and Komaki, 1967). Spreads consisted of 22 horizontal geophones at 2-m (6.6-ft) intervals. Coverage was not extended to more of the survey area because the large attenuation of shear energy in the gravel precluded initial shear arrivals from bedrock.

\section{INTERPRETATION OF SEISMIC COMPRESSIONAL WAVE DATA}

\section{Preliminary interpretation of spreads A, B, C, and D}

The analyses of seismic spreads A, B, C, and D recorded above Pierre Shale illustrated a factor which is usually not considered in the interpretation of refraction data, but which is occasionally present in shallow investigations. This factor is a rapid increase in velocity with depth within the target horizon (bedrock). This increase was masked on individual plots of the data either by timing errors or by lateral changes in depths or velocities.

Seismic recordings were of good quality and initial breaks were timed to $\pm 1 / 2 \mathrm{~ms}$. However, comparison of reciprocal times indicated that, at best, 1-ms timing accuracy was maintained. Time-distance $(T-X)$ graphs prepared from these recordings indicated the following conditions (see example in fig. 3). 


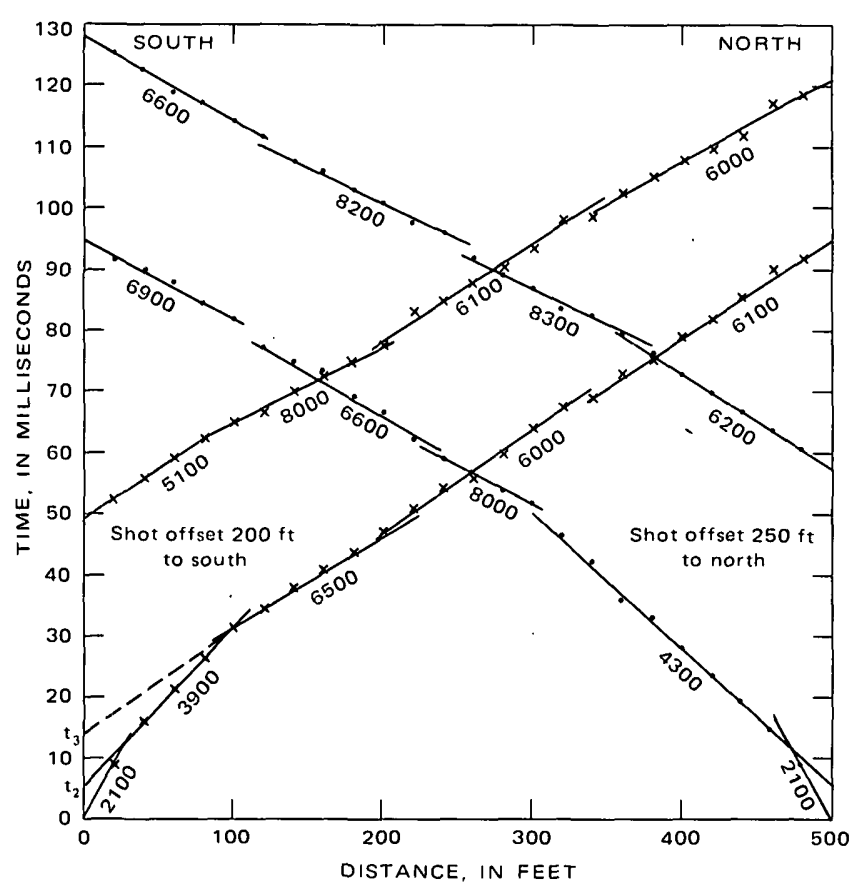

Figure 3.-Time-distance graph for spread C. Apparent velocities are in feet per second.

1. A first layer of compressional velocity $\alpha_{1} \approx 2,100 \mathrm{ft} / \mathrm{s}$.

2. A second layer with velocity $3,800<\alpha_{2}<4,400 \mathrm{ft} / \mathrm{s}$ and intercept time about $6 \mathrm{~ms}$. Thus the thickness of the first layer $Z_{1} \approx 7 \mathrm{ft}$.

3. A third layer (the Pierre Shale) which produced refracted arrivals easily envisioned as a series of straight line segments, the apparent velocities of which do not necessarily increase with distance from the shot. An average velocity of these segments is about $6,400 \mathrm{ft} / \mathrm{s}$.

4. The velocity distribution within the Pierre Shale increases with depth. This is evident because apparent velocities from bedrock for offset shots are consistently higher by several hundred feet per second than for the end shots.

Bedrock depths were computed from end shots by using the reciprocal time method of Hawkins (1961). Complete reverse coverage was obtained by using offset shots to project bedrock arrival times to the time axis. Three discrete layers were assumed: a top layer of constant thickness and velocity $(7 \mathrm{ft}$ and $2,100 \mathrm{ft} / \mathrm{s})$ underlain successively by pediment gravel of $4,200 \mathrm{ft} / \mathrm{s}$ and Pierre Shale of $6,400 \mathrm{ft} / \mathrm{s}$. The interpreted velocity section profile is shown in figure 4.

A conclusion based on this section could be that the bedrock surface of the Pierre Shale is irregular and that its depth ranges from $25 \mathrm{ft}$ at the shotpoint between spreads $C$ and $D$ to about $50 \mathrm{ft}$ in the center of all four spreads. These results, however, were questioned on two grounds: (1) The significantly greater depths calculated near the centers of all four spreads, and (2) the fact that the local irregularities in bedrock topography

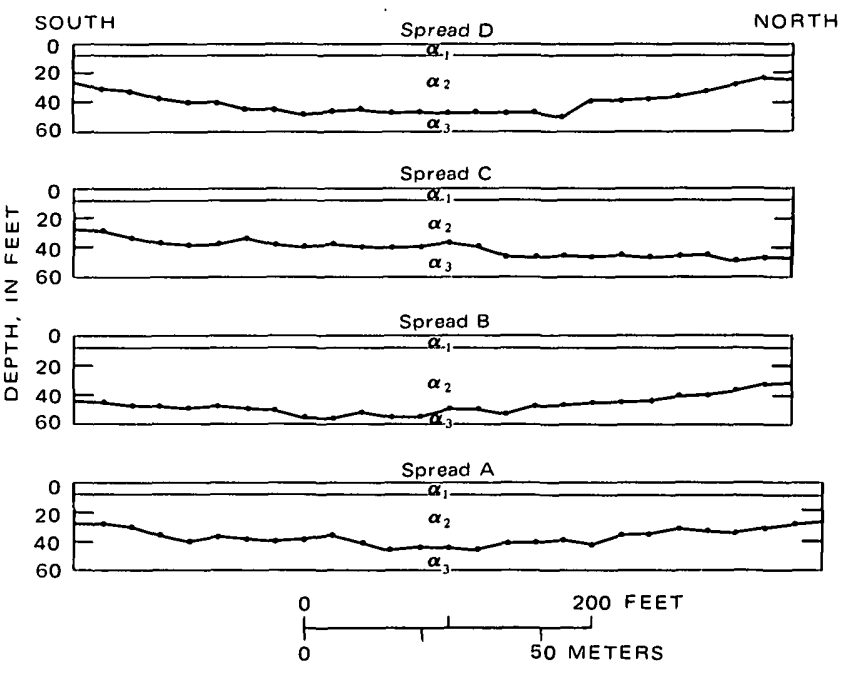

Figure 4.-Preliminary interpretatinons of spreads $A, B, C$, and D based in three layers. $\alpha_{1}=2,100 \mathrm{ft} / \mathrm{s}$ (weathered zone), $\alpha_{2}=$ $4,200 \mathrm{ft} / \mathrm{s}$ (pediment gravel) and $\alpha_{3}=6,400 \mathrm{ft} / \mathrm{s}$ (Pierre Shale).

resulted from millisecond delays in arrival times which were within the limits of timing accuracy. Hence the accuracy of the preliminary results was investigated in terms of the effect of two factors: (1) The increase in velocity with depth in the Pierre Shale, and (2) the effect of errors in timing initial arrivals.

\section{Effect of velocity variations in the Pierre Shale on depth calculation}

Vertical velocity variations within the Pierre Shale were investigated by constructing a single $T-X$ graph obtained from the average of all arrival times for constant shot-geophone distances (fig. $5 A$ ). The incorporation of offset shots into the averaging process permitted an effective spread length of 680 $\mathrm{ft}$. The result for distances greater than the critical distance $(140 \mathrm{ft})$ is a smooth convex curve to about $450 \mathrm{ft}$, indicating an initial increase in velocity with depth within the Pierre Shale. Beyond $450 \mathrm{ft}$, the slope is constant, indicating a velocity of about $7,250 \mathrm{ft} / \mathrm{s}$.

The $T-X$ graph was first stripped of the effect of overburden (2,100- and 4,200-ft/s layers) and the curved part approximated by a function representing a linear velocity increase with depth. A linear increase with depth is represented by the function $\alpha(Z)=\alpha_{0}+k Z$ (where $\alpha=$ velocity, $\alpha_{0}=$ initial velocity, $k=$ velocity gradient and $Z_{2}=$ depth). The corresponding $T-X$ graph has the form $T=\frac{2}{k} \sinh ^{-1} \frac{k \mathrm{X}}{2 \alpha_{0}}$ (Jakosky, 1940 , p. 755-758). The parameters obtained are $\alpha_{0}=5,600$ $\mathrm{ft} / \mathrm{s}$ and $k=21 \mathrm{ft} \mathrm{s}^{-1} \mathrm{ft}^{-1}$, with the curved portion representing a thickness $Z=80 \mathrm{ft}$. In other words, the initial velocity in the Pierre Shale is $5,600 \mathrm{ft} / \mathrm{s}$ and its vertical velocity gradient is approximately $21 \mathrm{ft} \mathrm{s}^{-1} \mathrm{ft}^{-1}$ through a thickness of $80 \mathrm{ft}$. Beyond this point the velocity may be assumed constant at 

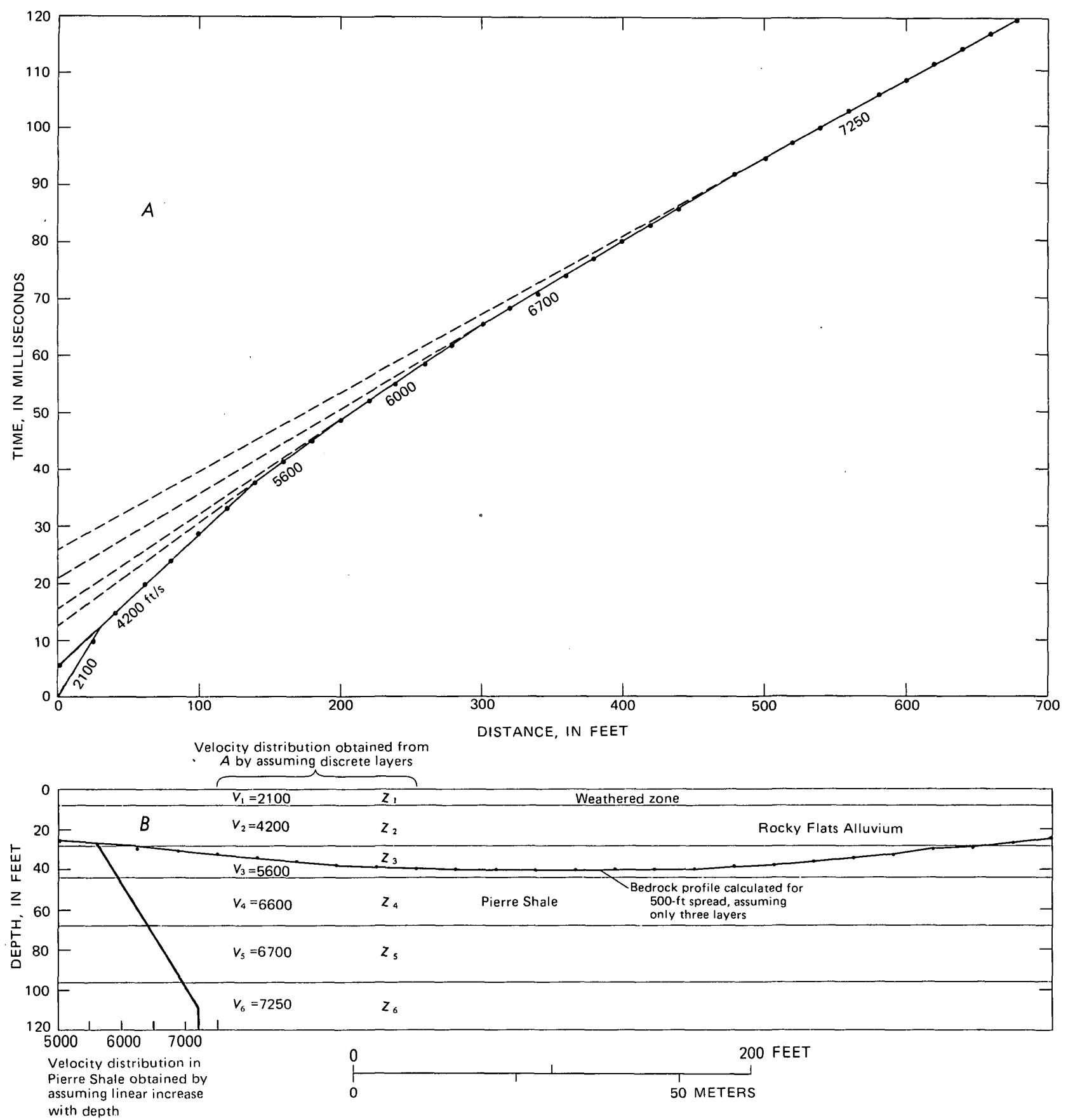

Figure 5.-Graph showing averaged arrival-time curve and interpreted section. $A$, Averaged arrival-time curve from spreads $\mathrm{A}, \mathrm{B}, \mathrm{C}$, and D above Pierre Shale. $B$, Interpreted section; $V$, velocity in feet per second; $Z$, thickness.

$7,250 \mathrm{ft} / \mathrm{s}$. This velocity distribution in the Pierre Shale is plotted in figure $5 B$ (linear increase with depth).

An equivalent depth profile consisting of discrete horizontal layers (fig. $5 B$ ) may be obtained from the average $T-X$ graph by approximating it with straight line segments (fig. $5 A$ ) and applying well-known formulas (Jakosky, 1940, p. 753). This is done to simplify later calculations.
The effect of a velocity gradient within bedrock on overburden depth calculations is evident upon examining a premise on which most schemes of depth computations are based; namely, that an arrival at a geophone represents a ray critically refracted at the interface between two different media. For the curved $T-X$ graph, arrivals represent rays which are not critically refracted at the Pierre Shale-overburden 
interface, but which instead have penetrated into bedrock (fig. 6). The penetration depth is a function of the geophoneshotpoint distance. Hence the combined path for rays from shotpoints $S^{\prime}$ and $S^{\prime \prime}$ to a point on the interface below a geophone at $G\left(S^{\prime} A+S^{\prime \prime} A\right.$ in fig. 6$)$ is not the same as the direct shotpoint-to-shotpoint path $\mathrm{S}^{\prime} B S^{\prime \prime}$. The path $\mathrm{S}^{\prime} A S^{\prime \prime}$ consumes more time than the path $S^{\prime} B S^{\prime \prime}$. Resultant bedrock depth calculations at $\mathrm{G}$ are in error, approximately by a factor of the difference in traveltime along these two paths.

The magnitude of the resultant error for the $500-\mathrm{ft}$ spreads is easily determined by applying Hawkins' method to the $T-X$

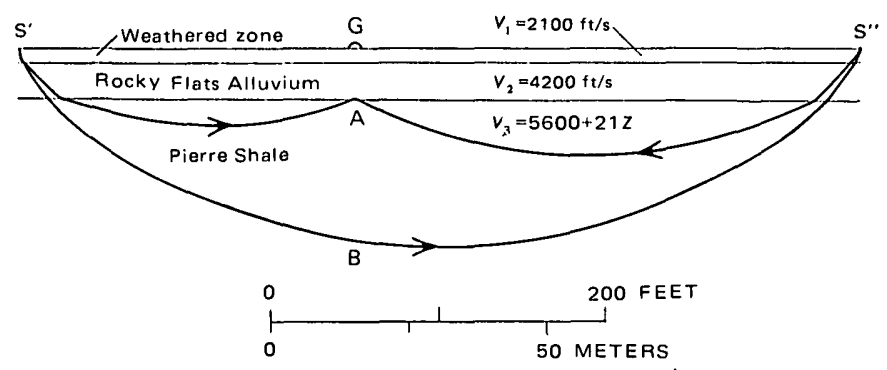

Figure 6.-Divergent ray paths in Pierre Shale drawn to scale for a $500-\mathrm{ft}$ spread. $S^{\prime}$ and $S^{\prime \prime}$, shotpoints; G, geophone; A and B, rays; $V$, velocity. graph of figure $5 A$, using an assumed bedrock velocity of $6,400 \mathrm{ft} / \mathrm{s}$. The bedrock profile so calculated is also sketched in figure $5 B$ (three-layer assumption). The results show an apparent profile which is very similar to those determined in the preliminary interpretations. It is concave downward toward the center of the spread and it has an amplitude of 15 ft. By comparing this profile with that of the overburden bedrock boundary interpreted assuming three discrete layers, the error can be observed. It is a minimum in the vicinity of the shotpoints and a maximum midway between them. A correction, based on these results, applied to the profiles in figure 4 eliminates the bedrock low in the center of the spreads. This correction is applied and the results are plotted as the points in figure $?$.

\section{Effect of errors in timing initial arrivals on depth calculations}

Timing errors resulting in incorrect depth calculations (1) at the shotpoint and (2) at points distant from the shot are considered.

Bedrock depths beneath a shotpoint are best determined using time-intercept methods (Dix, 1952, p. 245) because arrival times from intervening layers are available. Bedrock
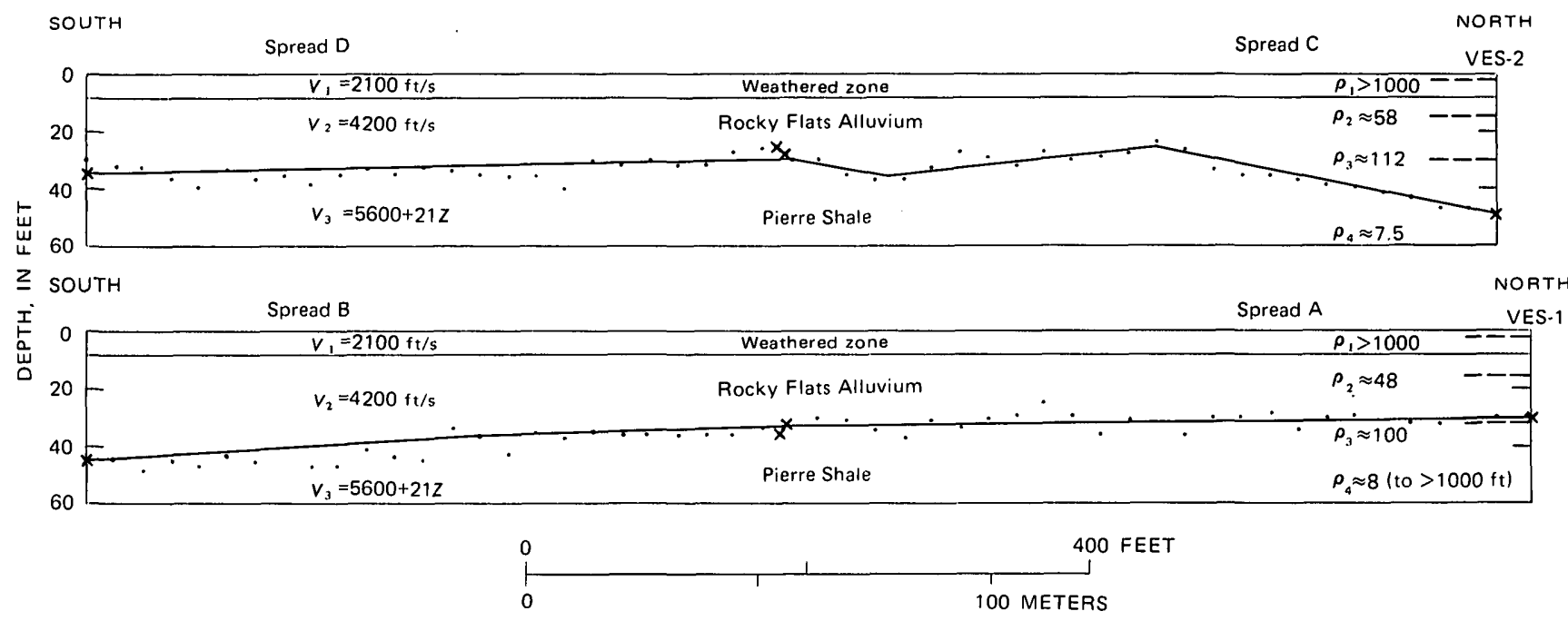

VERTICAL EXAGGERATION $\times 2$

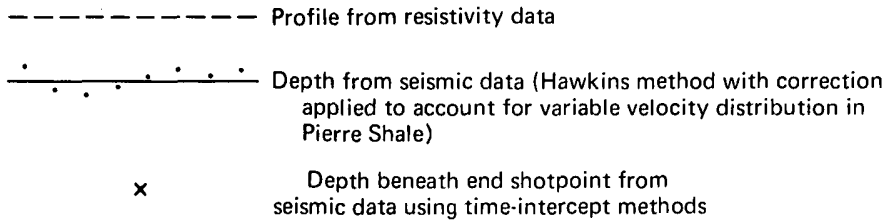

Figure 7.-Subsurface profile interpreted from seismic spreads A, B, C, and D and electric soundings VES-1 and VES-2. Resistivity $(\rho)$ in ohm-meters; velocity $(V)$ in feet per second. 
arrival times may be confidently projected to intercept the time axis through the use of offset shots ( $t_{3}$ in fig. 3 ). Furthermore, because shotpoint geophone distances are short, the effect of ray penetration into bedrock is small and the interpretation may be considered as one of only three layers.

The effect of errors in intercept time on depth calculations was determined using equations of Northwood (1967, p. 460) derived for a two-layer case. The effect of a third layer multiplies the possible error by approximately a factor of two because two intercept times ( $t_{2}$ and $t_{3}$ in fig. 3) must be considered. The resulting analysis, using $4,200 \mathrm{ft} / \mathrm{s}$ for overburden velocity and $5,600 \mathrm{ft} / \mathrm{s}$ for bedrock velocity, showed that at most a 5 -ft error in bedrock depth is possible for $1 \mathrm{~ms}$ errors in both $t_{2}$ and $t_{3}$.

At points distant from the shot, the effect of ray penetration into bedrock must be considered. The results show that large changes in bedrock depth cause only small changes in arrival time. This will be demonstrated using the discrete-velocity representation of figure $5 B$ and invoking delay-time formulas.

Assume that the thickness of the top layer $\left(z_{1}\right)$ remains constant and that changes in bedrock depth simply affect the thickness of layers 2 and 3 for example, $\left(Z_{2}+Z_{3}=C\right.$, a constant). Consider shotpoint geophone distances between 200 and $300 \mathrm{ft}$ for which initial arrivals represent critical refraction from layer 4 . The delay-time expression for a four-layer section (modified from Hawkins, 1961) is

$$
\begin{gathered}
t=\frac{Z_{1}}{K_{14}}+\frac{Z_{2}}{K_{24}}+\frac{Z_{3}}{K_{34}}=\sum_{i=1}^{3} \frac{Z_{i}}{K_{i 4}} \\
K_{i 4}=\frac{V_{i} V_{4}}{\sqrt{V_{4}^{2}-V_{l}^{2}}}
\end{gathered}
$$

where $t=$ delay time at geophone,

$Z_{i}=$ thickness of the $i$ th layer,

$V_{i}=$ velocity in the $i$ th layer, and

$K_{i 4}=$ velocity term which accounts for a slant ray

path. Substituting for $Z_{3}$ gives

$$
t=\frac{Z_{1}}{K_{14}}+\frac{Z_{2}}{K_{24}}+\frac{C-Z_{2}}{K_{34}}
$$

To determine the change in delay time corresponding to a change in the thickness $Z_{2}$, the above expression is differentiated with respect to $Z_{2}$ and gives

$$
\frac{\partial t}{\partial Z_{2}}=\frac{1}{K_{24}}-\frac{1}{K_{34}} \text {. }
$$

For the values of $V_{2}, V_{3}$, and $V_{4}$ in figure $5 B, K_{24}=5.9$ $\mathrm{ft} / \mathrm{ms}, k_{34}=15.6 \mathrm{ft} / \mathrm{ms}$, and $\partial t / \partial Z_{2}=0.11 \mathrm{~ms} / \mathrm{ft}$. Hence a 1-ms change in delay time corresponds to approximately a 9 -ft change in depth. For larger distances, at which ray penetration is deeper, the effect is still greater. Because the timing accuracy is $1 \mathrm{~ms}$, it is apparent that changes in bedrock depth of $10 \mathrm{ft}$ (or about 30 percent of the total depth) could well be hidden in scatter of the data points.

In order to determine whether the calculated delay-time variations within a spread were actually related to variations in bedrock depth or were simply a matter of timing errors, a statistical test was devised by which a correlation coefficient was calculated from all the delay times obtained for each spread. It was established that only for spread C could delays be related to local undulations in bedrock depth. Thus the bedrock high shown in the center of spread $\mathrm{C}$ (fig. 7) and the low at its north end are probably real. On the other hand, local bedrock undulations as large as $15 \mathrm{ft}$ could have remained undetected.

\section{Final depth computations for spreads $A$ through $\mathbf{J}$}

Final computations were made using intercept times to obtain depths beneath end shotpoints (shown as X's on figs. 7 and 8), and using delay times (Hawkins, 1961) to locate significant changes in bedrock depth within the spreads (shown as dots on figs. 7 and 8). For spreads A through C, the correction described earlier was applied to account for velocity variations within the Pierre Shale. Ray construction methods were used on spread $\mathrm{F}$ because of the complex bedrock profile at this location.

\section{INTERPRETATION OF RESISTIVITY DATA}

The Schlumberger depth-sounding curves (fig. 9) were interpreted by curve matching, using albums of master curves for vertical electrical soundings (Orellana and Mooney, 1966). The interpretations of VES-1 and VES-2 overlying Pierre Shale yielded almost identical geoelectric sections (fig. 9). They indicate three layers within the gravel of the Rocky Flats Alluvium: a 2-ft-thick top layer having resistivity greater than 1,000 ohm-m underlain by two 15-ft-thick layers having resistivities of about 55 and $105 \mathrm{ohm}-\mathrm{m}$, respectively. The underlying Pierre Shale, of very large thickness $(>1,000 \mathrm{ft})$, has a resistivity of about $8 \mathrm{ohm}-\mathrm{m}$.

Interpretation of VES-3 overlying the Laramie Formation indicates two layers within the gravel which correspond to the second and third layers of VES-1 and -2. The surface layer is $10 \mathrm{ft}$ thick and it has a resistivity of about $58 \mathrm{ohm}-\mathrm{m}$; it is underlain by a layer $65-85 \mathrm{ft}$ thick having a resistivity between 175 and 105 ohm-m. The underlying Laramie Formation has a resistivity of about $10.5 \mathrm{ohm}-\mathrm{m}$. This value of resistivity extends into the Laramie to a depth of about $500 \mathrm{ft}$ (fig. 2) where an insulator is encountered ( $\rho>50 \mathrm{ohm}-\mathrm{m})$.

The preceding interpretations are included in the profiles of figures 7 and 8 . 

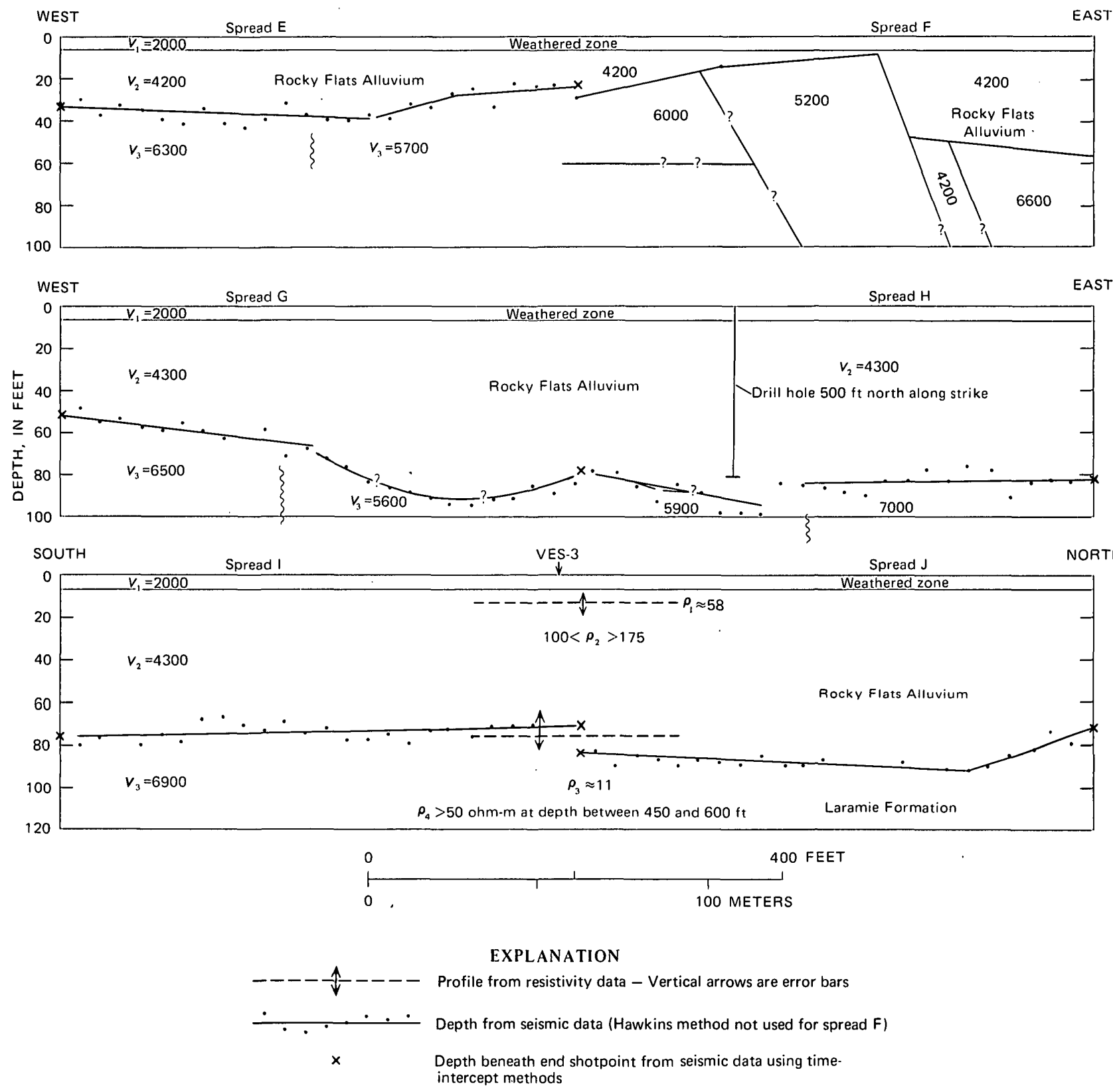

Figure 8.-Subsurface profile interpreted from seismic spreads E through $J$ and electric sounding VES-3. Resistivity $(\rho)$ in ohm-meters, velocity $(V)$ in feet per second.

\section{INTERPRETATION OF SEISMIC SHEAR-WAVE DATA}

Shear-wave recordings were made along seismic spreads $A$ and D which overlie the Pierre Shale. The rapid attenuation of shear energy in the pediment gravel precluded the use of spreads longer than about $150 \mathrm{ft}$.

The best seismogram of transverse motion obtained is shown in figure 10. The $X$ 's sketched on this recording represent times for initial compressional arrivals obtained using standard techniques. Thus the method employed for generating trans- verse motion effectively supresses compressional energy. The coherent wave train following the initial shear $(\mathrm{SH})$ arrival is the Love wave.

Analysis of the shear-wave data yielded the following results:

1. A first layer about $5 \mathrm{ft}$ thick of shear velocity $\beta_{1} \approx 1,200$ $\mathrm{ft} / \mathrm{s}$. This layer corresponds to the first layer $\left(\alpha_{1} \approx 2,100\right.$ $\mathrm{ft} / \mathrm{s}$ ) obtained from the compressional wave data.

2. A second layer of velocity $\beta_{2} \approx 2,200 \mathrm{ft} / \mathrm{s}$, for which $\alpha_{2} \approx 4,200 \mathrm{ft} / \mathrm{s}$.

3. No deeper layer was recorded. 


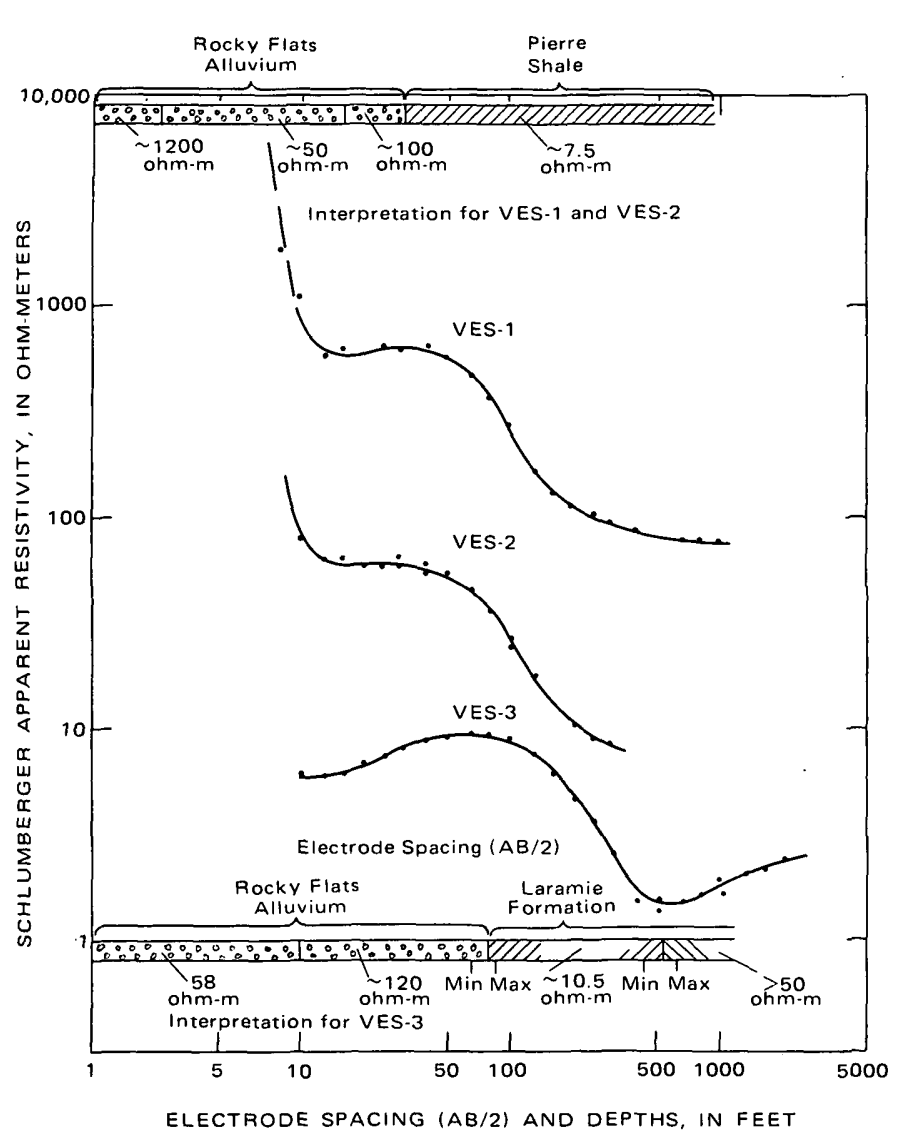

Figure 9.-Interpretation of resistivity soundings VES1, VES-2, and VES.3.

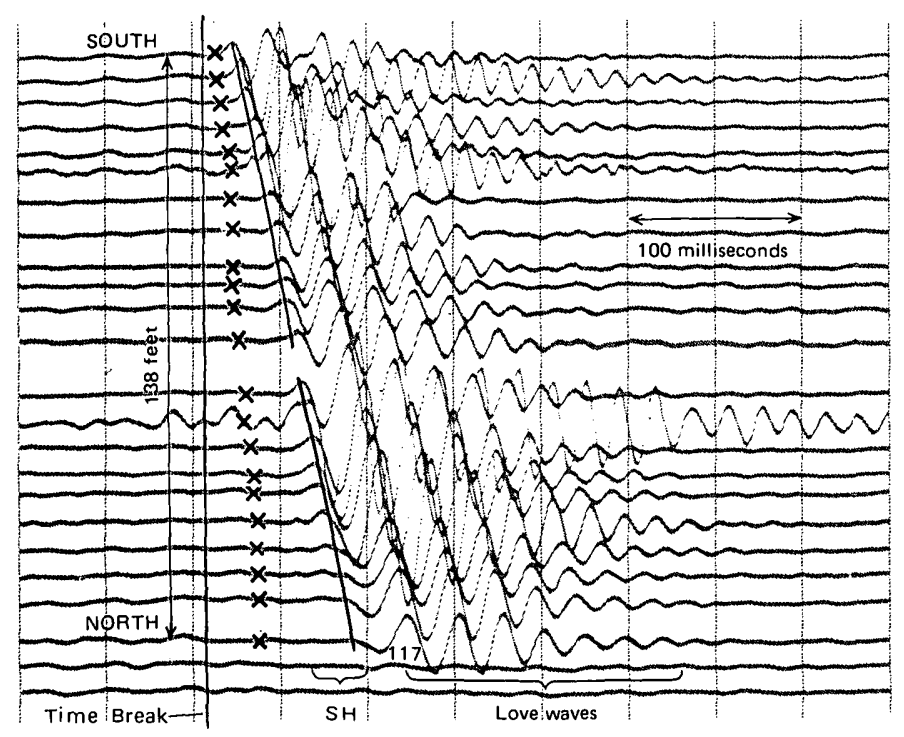

Figure 10.-Seismogram of transverse motion recorded at south end of spread D. X's represent arrival times of initial compressional motion. $\mathrm{SH}$, initial shear-wave arrival.
The elastic constants of the Rocky Flats Alluvium were calculated (Birch, 1966, p. 100) from the preceding results using an assumed density of $2.0 \mathrm{~g} / \mathrm{cm}^{3}$. Values are shown in table 1. Elastic constants calculated from velocities in unweathered Pierre Shale near Limon, Colo. (McDonal and others, 1958), are also shown. A density of $2.2 \mathrm{~g} / \mathrm{cm}^{3}$ was used for the Pierre Shale.

The shear-wave velocities for unweathered Pierre Shale obtained at Limon and those of the Rocky Flats Alluvium are nearly equal (table 1). Because the upper $80 \mathrm{ft}$ of the Pierre Shale at Rocky Flats has a lower compressional velocity than that shown in table 1 , its shear velocity probably is also less. Therefore the contact between Rocky Flats Alluvium and Pierre Shale at Rocky Flats is probably represented by a shear-wave velocity inversion. Consequently this contact probably could not have been detected with the technique employed, even with a more powerful energy source.

Table 1.-Velocities and elastic constants for Rocky Flats Alluvium and for unweathered Pierre Shale near Limon, Colo.

\begin{tabular}{|c|c|c|c|}
\hline \multirow{2}{*}{ Factor } & \multicolumn{2}{|c|}{ Rocky Flats Alluvium } & \multirow{2}{*}{$\begin{array}{l}\text { Pierre Shale, } \\
\text { Limon, Colo. } \\
\text { (McDonal and } \\
\text { others, 1958) }\end{array}$} \\
\hline & Layer 1 & Layer 2 & \\
\hline Compressional velocity . . (ft/s) & 2,100 & 4,200 & 7,100 \\
\hline Shear velocity $(\mathrm{SH})$. & 1,200 & 2,200 & 2,600 \\
\hline Density (assumed) $\ldots \ldots\left(\mathrm{g} / \mathrm{cm}^{3}\right)$ & 2.0 & 2.0 & 2.2 \\
\hline Poissons ratio $\ldots \ldots \ldots \ldots \ldots$ & .26 & .31 & .42 \\
\hline Shear modulus .. $\left(\mathrm{lb} / \mathrm{in}^{2} \times 10^{5}\right)$ & .38 & 1.3 & 2.0 \\
\hline Youngs modulus. $\left(\mathrm{lb} / \mathrm{in}^{2} \times 10^{5}\right)$ & .97 & 3.4 & 5.7 \\
\hline Bulk modulus .. $\left(\mathrm{lb} / \mathrm{in}^{2} \times 10^{5}\right)$ & .67 & 3.0 & 12.2 \\
\hline
\end{tabular}

\section{DISCUSSION OF RESULTS}

\section{Bedrock profiles}

The seismic data indicate a compressional wave-velocity increase, throughout the survey area, from about $4,200 \mathrm{ft} / \mathrm{s}$ to values between 5,200 and $6,900 \mathrm{ft} / \mathrm{s}$ at depths which ranged from about 10 to $90 \mathrm{ft}$. This velocity increase is assumed to define the overburden-bedrock boundary. Of the three electrical soundings, two (VES-1 and VES-3) indicated a resistivity contrast, from 100-175 ohm-m, typical of gravel, to 8-11 ohm-m, typical of shale at depths which agree with bedrock depths from the seismic interpretation. The third (VES-2) placed the resistivity contrast about $16 \mathrm{ft}$ shallower than the velocity change.

The bedrock profile of the Pierre Shale (fig. 7) interpreted from the seismic data indicates a fairly uniform 30-ft depth, interrupted by a broad channellike depression about $16 \mathrm{ft}$ deep centered at the location of VES-2. The electrical soundings VES-1 and VES-2, however, indicate nearly identical geoelectric sections, with a transition from about 110 to $8 \mathrm{ohm}-\mathrm{m}$ at a depth of $30 \mathrm{ft}$. The apparent discrepancy between the seismic and resistivity interpretations at VES-2 is greater than allowed by the resolution of either method. It 
may be reconciled by assuming either that a large local velocity inversion occurs within the overburden, affecting seismic depth calculations but not resistivity, or that the interpreted resistivity contrast does not represent the transition from overburden into bedrock. A likely explanation is that a channel within bedrock actually exists which possibly is filled with water-saturated material containing a large percentage of fine silt and clay whose resistivity is less than the overlying gravel.

The rapid increase in velocity with depth (from 5,600 to $7,200 \mathrm{ft} / \mathrm{s}$ ) within the upper $80 \mathrm{ft}$ of the Pierre Shale may indicate that weathering of the Pierre's clay minerals has occurred to this level. A velocity log in a test hole near Limon, Colo. (McDonal and others, 1958), where the Pierre is flat lying, also displays a similar though less rapid increase from 5,600 to $6,300 \mathrm{ft} / \mathrm{s}$ in the upper $80 \mathrm{ft}$, below which continued increase is very gradual.

Spreads $\mathrm{E}$ through $\mathrm{H}$ were perpendicular to the regional strike and revealed gross variations in both bedrock topography and velocity (fig. 8). The velocity ranges from 5,200 to $7,000 \mathrm{ft} / \mathrm{s}$ and qualitatively expresses changes in lithology within the Laramie. The minimum velocity corresponds to a bedrock ridge, which probably represents a resistant bed in the Laramie, about $10 \mathrm{ft}$ below the surface adjacent to an open pit claystone mine. The correspondence between a velocity minimum and a resistant bed is atypical. Resistant beds, unless they are fractured, usually have higher velocities than nonresistant beds.

Bedrock depth changes abruptly from 10 to $40 \mathrm{ft}$ at the east end of spread $\mathrm{F}$, where a steeply dipping low-velocity zone (about 4,200 ft/s), which may indicate a fault, occurs within the Laramie Formation. Beyond this point, bedrock depth increases gradually eastward to about $80 \mathrm{ft}$. This depth agrees with the results of the drill hole $500 \mathrm{ft}$ northward along strike.

Spreads I and J (fig. 8), parallel to the regional strike, indicate a constant bedrock velocity of $6,900 \mathrm{ft} / \mathrm{s}$ and an average depth of $80 \mathrm{ft}$, values within the range interpreted from VES 3.

\section{Variations in velocity, resistivity, and elastic constants within the Rocky Flats Alluvium}

Although bedrock is marked by a change in both velocity and resistivity, depths at which changes in velocity and resistivity occur within the Rocky Flats Alluvium do not agree.

The seismic data indicate only one velocity change, which is marked throughout the area by a rapid increase in $\alpha$ from about 2,100 to $4,200 \mathrm{ft} / \mathrm{s}$ and in $\beta$ from about 1,200 to 2,200 $\mathrm{ft} / \mathrm{s}$ at a depth of roughly $6 \mathrm{ft}$. Such a change is frequently encountered where a thick soil cover exists, and is simply indicative of a rapid near-surface decrease in porosity with depth. A $4,200-\mathrm{ft} / \mathrm{s}$ compressional velocity is reasonable for dry gravel and boulders within a matrix of finer grained material, but is probably too low for water-saturated gravel and boulders. Furthermore, because moisture does not affect shear velocities to the extent to which it affects compressional velocities, the transition from lower to higher values for both $\alpha$ and $\beta$ at approximately the same depth implies that the transition is not caused by water.

The electrical resistivity data, on the other hand, indicate a change in the physical property of the gravels, at about $15 \mathrm{ft}$, marked by an increase in resistivity from about 55 to 100 ohm-m. This contrast is probably due to a decrease in the percentage of silt or clay within the gravel.

Water-saturated gravel is not necessary for the interpretation of either the seismic or resistivity results. The lack of an observed increase in velocity beyond $4,200 \mathrm{ft} / \mathrm{s}$ practically precludes the existence of a shallow water-saturated zone. A zone of saturation could exist within approximately $10 \mathrm{ft}$ above the level of the Pierre Shale, and at somewhat higher levels where bedrock is deeper, and yet remain undetected by the seismic method. Thus the broad shallow channellike depression interpreted from seismic spreads C and D could be water saturated.

The only restriction which the resistivity results place on the ground water relates to the quality of the water; resistivities as large as $100 \mathrm{ohm}-\mathrm{m}$ preclude the existence of brackish water in the overburden.

The elastic constant results (table 1 ) cannot be readily interpreted because the literature lacks a body of data for the static elastic properties of unconsolidated material obtained in situ. Drew Tiedemann, with the U.S. Bureau of Reclamation (oral commun., 1973), indicated that the values obtained for the shear modulus, Youngs modulus, and bulk modulus are surprisingly large. In fact, they more nearly approach the numbers calculated for unweathered Pierre Shale. The value of Poissons ratio is in the range expected for coarse materials.

\section{Resistivities within the Laramie Formation}

Based on geologic evidence the division of the Laramie Formation into two parts-an upper clayey and a thinner lower sandy part (Spencer, 1961)-is similarly displayed by the results of VES-3. The interpretation indicates an increase in resistivity from about 11 to more than $50 \mathrm{ohm}-\mathrm{m}$ at a depth between 450 and $600 \mathrm{ft}$. Based on the profile of figure 2, this change in resistivity occurs in the lower $150-300 \mathrm{ft}$ of the Laramie Formation.

\section{ACKNOWLEDGMENTS}

I thank Marcus E. Church for permission to conduct this work on his property and thank Adel A. R. Zohdy, of the U.S. Geological Survey, for directing the resistivity work and aiding in its interpretation. 


\section{REFERENCES CITED}

Birch, Francis, 1966, Compressibility-Elastic constants, sec. 7, Clark, S. P., Jr., ed., Handbook of physical constants: Geol. Soc. America Mem. 97, p. 97-173.

Dix, C. H., 1952, Seismic prospecting for oil: New York, Harper \& Bros., 414 p.

Hawkins, L. V., 1961, The reciprocal method of routine shallow seismic refraction investigations: Geophysics, v. 26, no. 6, p, 806-819.

Jakosky, J. J., 1940, Exploration geophysics: Los Angeles, TimesMirror Press, 786 p.

Malde, H. E., 1955, Surficial geology of the Louisville quadrangle, Colorado: U.S. Geol. Survey Bull. 996-E, p. 217-259.

McDonal, F. J., Angona, F. A., Mills, R. L., Sengbush, R. L., Van Nostrand, R. G., and White, J. E., 1958, Attenuation of shear and compressional waves in Pierre Shale: Geophysics, v. 23, no. 3, p. $421-439$.

Northwood, E. J., 1967, Notes on errors in refraction interpretation, in
Musgrave, A. W., ed., Seismic refraction prospecting: Soc: :Explor: Geophysicists, p. 459-465.

Onda, I., and Komaki, S., 1967, Waves generated from a linear horizontal traction with finite source length on the surface of a semi-infinite elastic medium, with special remarks on the theory of shear wave generator: Tokyo Univ. Earthquake Research Inst. Bull., v. 46, p. 1-23.

Orellana, Ernesto, and Mooney, H. M., 1966, Master tables and curves for vertical electrical sounding over layered structures: Madrid, Intersciencia, $125 \mathrm{p}$.

Scott, G. R., 1960, Subdivision of the Quaternary alluvium east of the Front Range near Denver, Colorado: Geol. Soc. America Bull., v. 71 , no. 10, p. 1541-1544.

Spencer, F. D., 1961, Bedrock geology of the Louisville quadrangle, Colorado: U.S. Geol. Survey Geol. Quad. Map GQ-151.

Van Horn, R., 1957, Bedrock geology of the Golden quadrangle, Colorado: U.S. Geol. Survey Geol. Quad. Map GQ-103.

Van Nostrand, R. G., and Cook, K. L., 1966, Interpretation of resistivity data: U.S. Geol. Survey Prof. Paper 499, 310 p. 


\title{
PALYNOLOGY AND STRATIGRAPHY OF CRETACEOUS STRATA IN LONG ISLAND, NEW YORK, AND BLOCK ISLAND, RHODE ISLAND
}

\author{
By LESLIE A. SIRKHN, Garden City, N.Y. ${ }^{1}$
}

\begin{abstract}
Palynologic analysis of core samples from Fire Island well, S21,091 T, in southern Long Island and of surface samples from Garvies Point in northern Long Island and from eastern Block Island indicates that the Cretaceous of this region includes Raritan, Magothy, Matawan, and Monmouth (as previously defined) strata, and ranges in age from Cenomanian to Maestrichtian, in agreement with recent studies in New Jersey. In this study, the oldest Cretaceous, which is equivalent to the Woodbridge Clay Member of the Raritan Formation of New Jersey, occurs just above sea level at Garvies Point, Glen Cove, and in the Port Washington sand pits in northwestern Long Island, whereas sediments from near the base of the Fire Island well are correlated with the South Amboy Fire Clay Member. The Magothy and Matawan combined in Long Island are about $1,500 \mathrm{ft}(457 \mathrm{~m})$ thick, whereas in New Jersey both units rarely excced a thickness of $500 \mathrm{ft}(152 \mathrm{~m})$. Outcropping Cretaceous sediments in Block Island are equivalent to the South Amboy Fire Clay Member rather than the Magothy, as indicated in prior studies. Palynologic zonation of the Late Cretaceous is tentatively extended to Magothy and younger strata on the basis of the appearance and proliferation of the more advanced, angiosperm pollen forms. This study also provides a basis for extending the zonation and hence the correlation to the sediments of the Continental Shelf.
\end{abstract}

Until 1965 (Perlmutter and Todd, 1965), the Cretaceous deposits beneath the Pleistocene beds of Long Island were traditionally assigned to the Magothy(?) and Raritan Formations on the basis of lithologic correlation with outcropping Cretaceous strata in New Jersey. The Raritan-Magothy(?) contact was generally placed at what has been identified in well sections as the clay-rich Raritan sequence. The Magothy(?) included the sediments, predominantly sands, between the clay and the Pleistocene outwash. Because the limits and thickness of the Magothy and the extent of the Raritan in Long Island have been in question, and because of recent palynologic evidence for the age of Raritan and Magothy sequences in New Jersey, this study has been undertaken to provide data relevant to the Cretaceous stratigraphy in Long Island and Block Island, with specific emphasis on the subsurface Raritan-Magothy boundary problem.

\footnotetext{
${ }^{1}$ Department of Earth Sciences, Adelphi University.
}

\section{PREVIOUS INVESTIGATIONS}

Studies of pollen and spores in the nonmarine Cretaceous have contributed to the development of a zonation for these strata. In Maryland and Delaware, Groot and Penny (1960) suggested that the oldest of these sediments could be of Neocomian Age. In New Jersey, Groot, Penny, and Groot (1961) correlated the Woodbridge Clay Member with the lower Tuscaloosa Formation of Alabama. The Tuscaloosa was subsequently studied by Leopold and Pakiser (1964) and assigned to the Cenomanian Stage. The Raritan Formation was placed in the Upper Cretaceous by Richards (1943) and Stephenson (1954). The marine Raritan in New Jersey was assigned a Senonian Age by Gray and Groot (1.966). Alternatively, Kimyai (1966) placed the Raritan of New Jersey in earliest Late Cretaceous (Cenomanian), citing the presence of small tricolpate pollen.

The Magothy was considered to be Turonian in age by Dorf (1952). This age was accepted by Groot, Penny, and Groot (1961) because the pollen forms, namely triporate angiosperm pollen, are more advanced than those of the Raritan and may be correlated with those of the Turonian in Europe. Groot and Groot (1962) also placed the Potomac Group in the Early Cretaceous (Aptian and Albian Stages). They found the first angiosperm pollen in Albian Age strata and recorded the dominance of this group in Cenomanian microfloras.

Palynologic zonation of the Cretaceous in Maryland was initiated by Brenner (1963). In this scheme the Patuxent Formation and the Arundel Clay of the Potomac Group represent Zone I, correlative with the Aptian and possibly Barremian Stages. This zone is characterized by the dominance of fern spores and gymnosperm pollen. Triaperturate angiosperm pollen is not found here. The Patapsco Formation is mainly Albian in age and is placed in Zone II, which in turn is divided into subzones IIA and IIB. These subzones reflect the appearance and proliferation, respectively, of tricolpate angiosperm pollen. Although Brenner recognized a differentiation between Raritan and Patapsco microfloras, the Raritan was not zoned.

The basis for extending the zonation into the Upper Cretaceous was provided by Wolfe and Pakiser (unpub. data, 1968), who established a transitional Raritan Zone in which 
triporate angiosperm pollen, mainly the "older Normapolles" forms, first appear (fig. 1). Increases in the number of triaperturate angiosperm species and the ranges of pollen and spores in Cretaceous strata in New Jersey enabled Wolfe and

\begin{tabular}{|c|c|c|}
\hline Stage & $\begin{array}{l}\text { Pollen zones } \\
\text { (Gill and others, } \\
\text { 1969; Doyle,1969b) }\end{array}$ & $\begin{array}{l}\text { Distinctive triaperturate pollen forms, } \\
\text { Doyle (1969a, b), } \\
\text { Wolfe and Pakiser (1971) }\end{array}$ \\
\hline Maestrichtian & & \multirow{4}{*}{$\begin{array}{l}\text { Triporates (advanced Normapolles; new } \\
\text { triporates) } \\
\text { Tricolporates (advanced forms, complicated } \\
\text { sculpture) } \\
\text { Tricolpates (complicated sculpture) }\end{array}$} \\
\hline \multirow[t]{2}{*}{ Campanian } & & \\
\hline & \multirow{2}{*}{ VII } & \\
\hline Santonian & & \\
\hline Coniacian & \multirow{2}{*}{ VI } & \multirow{2}{*}{ Not present in study area } \\
\hline Turonian & & \\
\hline \multirow{2}{*}{ Cenomanian } & $\mathrm{V}$ & $\begin{array}{l}\text { Triporates ("old" Normapolles; new triporates) } \\
\text { Tricolporates (larger, oblate, advanced forms) } \\
\text { Tricolpates (few forms) }\end{array}$ \\
\hline & IV & $\begin{array}{l}\text { Tricolpates ("old" Normapolles) } \\
\text { Tricolporates (triangular; reticulate) } \\
\text { Tricolpates (prolate, psilate) } \\
\text { Tetrads }\end{array}$ \\
\hline
\end{tabular}

Figure 1.-Biostratigraphic zonation of the Upper Cretaceous of New Jersey, New York, and Rhode Island on the basis of triaperturate pollen.

Pakiser (1971) to show that (1) the Patapsco Formation of Maryland, as defined by Owens and Sohl (1969), ranges from the middle Albian into earliest Cenomanian, (2) the Raritan Formation is confined to the medial part of the middle Cenomanian, and (3) the Magothy Formation of New Jersey ranges from Santonian to earliest Campanian. Both the transitional Patapsco-Raritan of Maryland and New Jersey have been referred to the upper Patapsco, on the basis of the work of Owens and others $(1968,1970)$ and Wolfe and Pakiser (1971). Sohl (in Owens and others, 1970) also assigned to the Magothy of New Jersey a Santonian to earliest Campanian Age on the basis of Molluscan faunas.

Doyle $(1969 \mathrm{~b})$. traced possible evolutionary trends in the assemblages of dicotyledonous angiosperm pollen from the transitional Raritan through the Woodbridge Clay Member, the South Amboy Fire Clay Member, and into the Magothy Formation. Subsequently, Gill, Sirkin, and Doyle (1969) assigned the transitional Raritan or upper Patapsco to Zone III and the Woodbridge Clay Member to Zone IV, as suggested by Doyle (1969b). It is now feasible to expand the zonation by placing the South Amboy Fire Clay Member of New Jersey in Zone V and the Magothy of New Jersey in Zone VII, reserving Zone VI for the missing unit(s) represented here by an unconformity.

Zones IV, V, and VI reflect evolutionary changes in angiosperm pollen and the first appearance of certain angiosperm genera, as described by Wolfe and Pakiser (1971) and Doyle (1969a). Because the pollen assemblages of the
Patapsco, the Woodbridge, and the South Amboy Fire Clay Member are so significantly different, distinct and separate zones for the Woodbridge Clay Member and the South Amboy Fire Clay Member seem more appropriate. The more prolific microflora attributed to the younger Magothy and to the Matawan by Wolfe and Pakiser (1971) may be further zoned, as necessary. These Upper Cretaceous sediments are currently being studied in more detail by J. A. Wolfe (oral commun., 1972). This zonation will also accommodate the inclusion of new pollen data from this region and the Continental Shelf. The overall zonation outlined here provides the basis for the stratigraphic correlations made in this study (figs. 1, 2).

Thus, tricolporate pollen in samples from Elk Neck, Md., (J. P. Owens, oral commun., 1972) represent Zone III and may be basal Cenomanian in age. The first triporates are found in the Woodbridge Clay Member, as observed in samples from New Jersey (Wolfe and Pakiser, 1971; Doyle, 1969a,b). According to Owens and others $(1968,1970)$, the Raritan Formation is restricted to the Raritan embayment in New Jersey. Both Doyle (1969a) and Wolfe and Pakiser (1971) have stressed that a major hiatus occurs between the Raritan and the Magothy in New Jersey, in agreement with Sohl (in Owens and others, 1970, fig. 23).

Biostratigraphic evidence for the age of Cretaceous strata in the Long Island, N.Y., region has been limited and predates the current zonation. For example, Baskerville (1965) identified the Cretaceous in Staten Island as "Raritan-Magothy" undifferentiated, and of earliest Cenomanian to early Senonian Age. The pollen and spores in Cretaceous sediments in the Brookhaven, Long Island, well were studied by Steeves (1959), who differentiated between the Raritan and Magothy Formations. Steeves divided the Raritan into Lower and Upper Cretaceous members, correlating the lower unit with the Potomac Group. In southern Long Island, Perlmutter and Todd (1965) demonstrated the presence of strata of the Monmouth Group, which they distinguished from the underlying undifferentiated Magothy-Matawan sediments mainly by Foraminifera.

North of Maryland, Cretaceous deltaic sediments are dominated by increasingly younger strata. The Potomac composes much of the sequence in Maryland, whereas the Raritan, Magothy, Matawan, and Monmouth formations are more prevalent in the clastic wedge in eastern New Jersey and New York. (Owens and others, 1968, 1970.) Thus the Cretaceous in Long Island consists of a greater thickness of Upper Cretaceous sediments with younger Cretaceous strata offlapping southward, generally similar to the southeastward offlap of these sediments in southern New Jersey. In Block Island, the Cretaceous has been termed "Magothy clay" on lithic evidence (Woodworth, 1934). This clay unit is interpreted to be about $135 \mathrm{ft}(41 \mathrm{~m})$ thick in seismic and well-log studies (Tuttle and others, 1961). However, biostratigraphic data has not previously been applied to these sediments. 


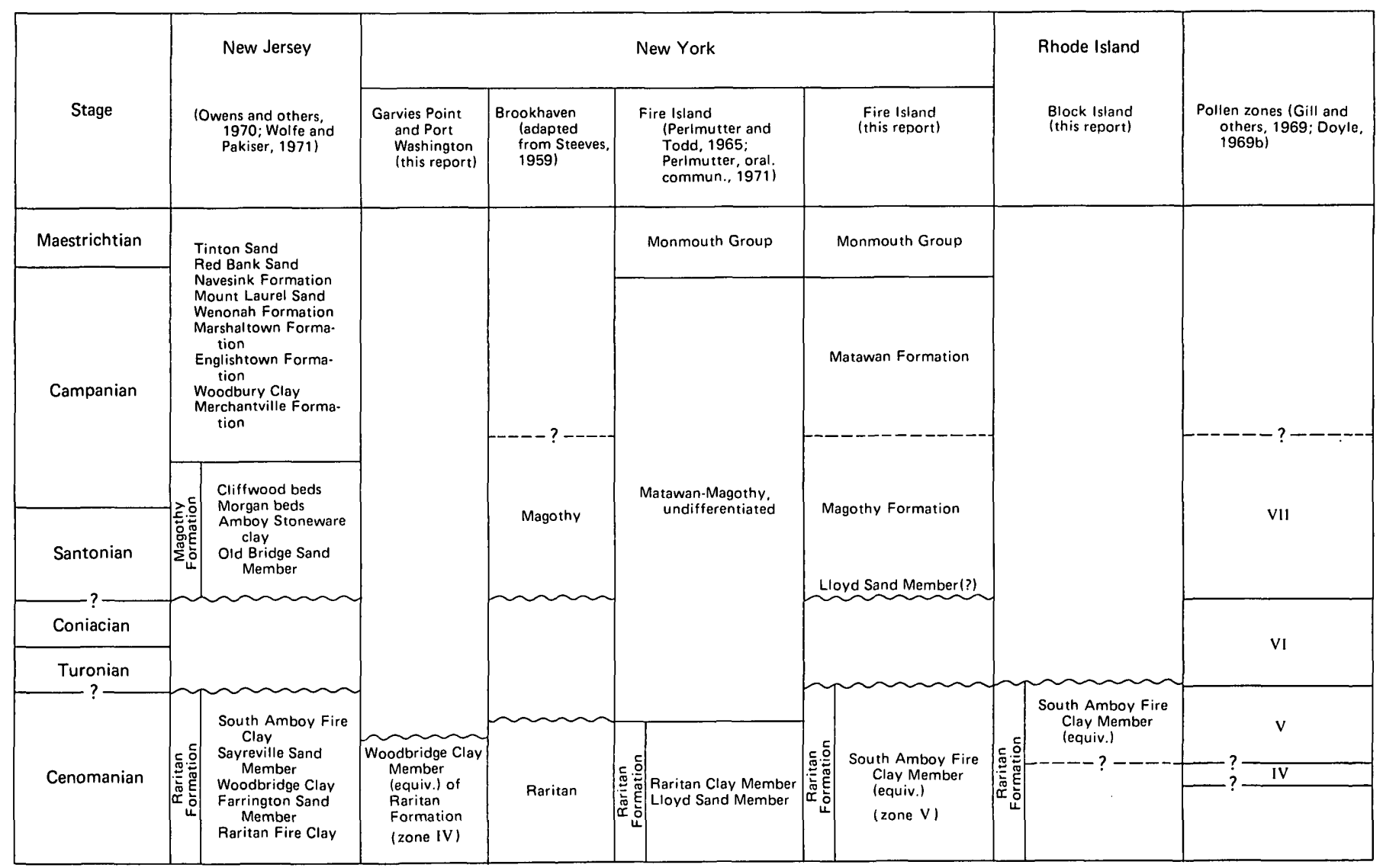

Figure 2.-Correlation of Upper Cretaceous formations, New Jersey to Block Island, R.I.

\section{METHODS}

Most of this investigation concerns the palynology of 50 well-core samples from the Fire Island, N.Y., test well, S21,091T (fig. 3). These samples were provided for pollen analysis by Nathaniel Perlmutter of the U.S. Geological Survey. The well, which is on the Fire Island barrier bar on the south side of Long Island, is significant because it extends completely through the Coastal Plain section to bedrock at a depth of about $1,960 \mathrm{ft}(597 \mathrm{~m})$.

Additional samples were collected (by the author) from cliff sections at Garvies Point in Glen Cove and at the sand pits in Port Washington, both on Hempstead Harbor in northwestern Long Island, and in southeastern and northeastern Block Island, R.I. (fig. 3). These sites are representative of the limited exposure of Cretaceous strata north of New Jersey (fig. 3 ). The cliff sections all appear to have been ice shoved during the late Pleistocene (Woodfordian) glaciation. Cretaceous clasts are occasionally found stacked in the drift, and most Cretaceous sections dip at extraordinary angles. However, cores of Cretaceous sediments at depth are not available so that the ages of these sediments have not yet been determined.

Samples were processed by standard techniques for pollen analysis. Identification of pollen and spores was based on

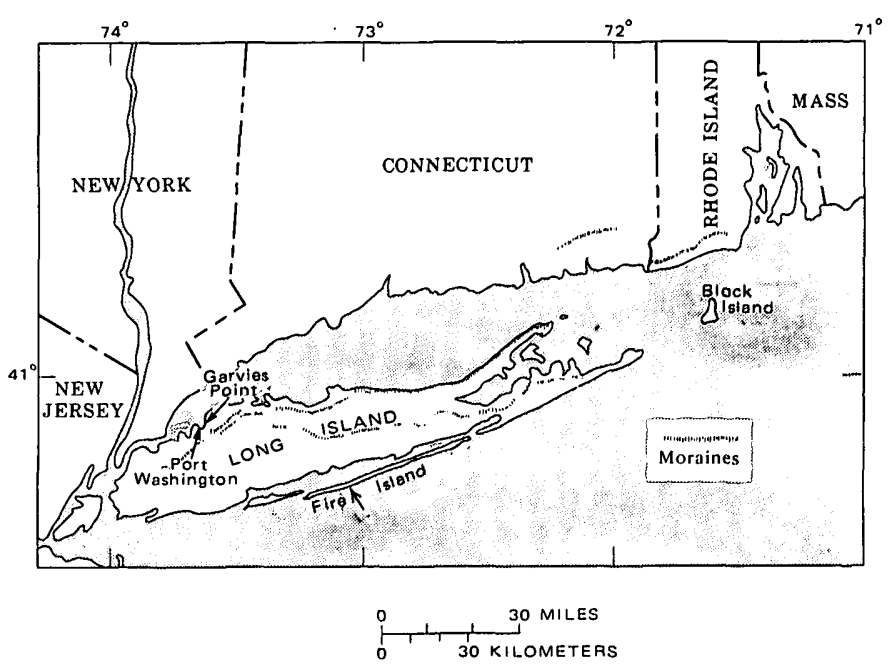

Figure 3.-Sample sites on Long Island and Block Island.

descriptions and figures in the references cited and specimens of representative pollen are illustrated in figures 4,5 , and 6 . Results are summarized in a percentage diagram (fig. 7). 


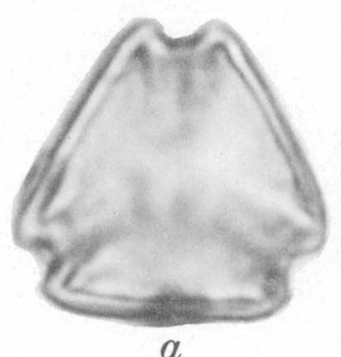

$a$

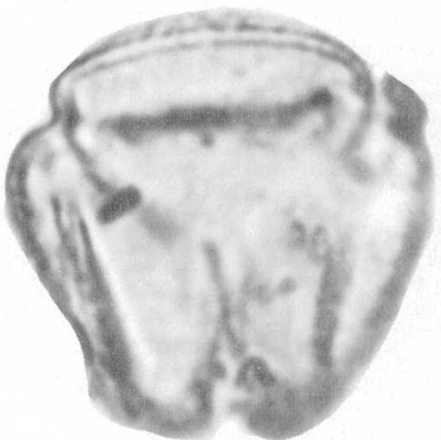

$e$

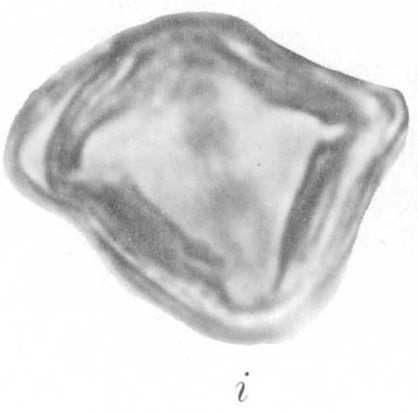

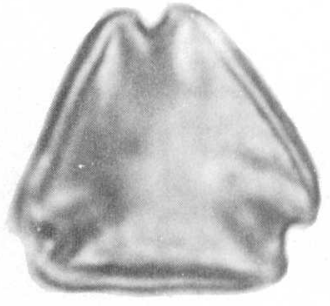

$b$
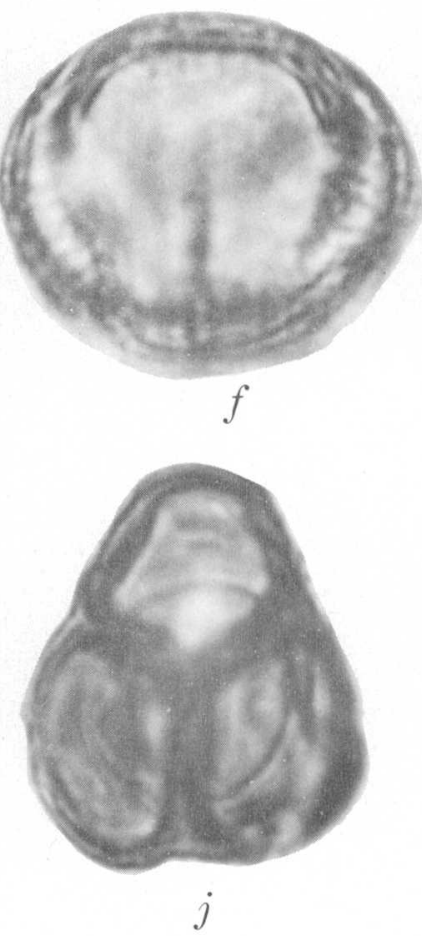
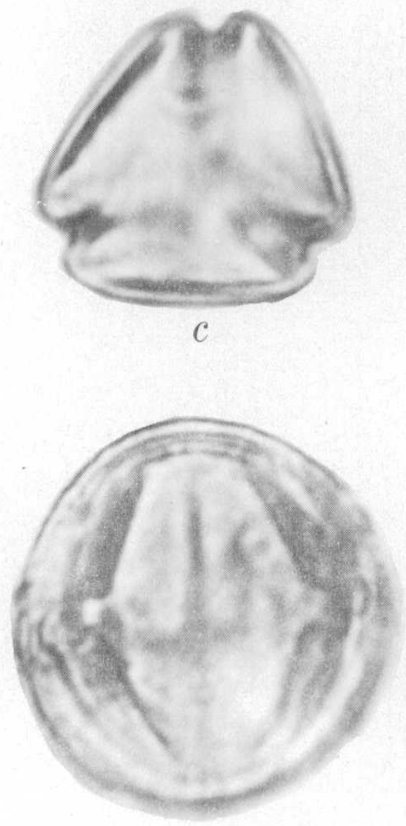

$y$
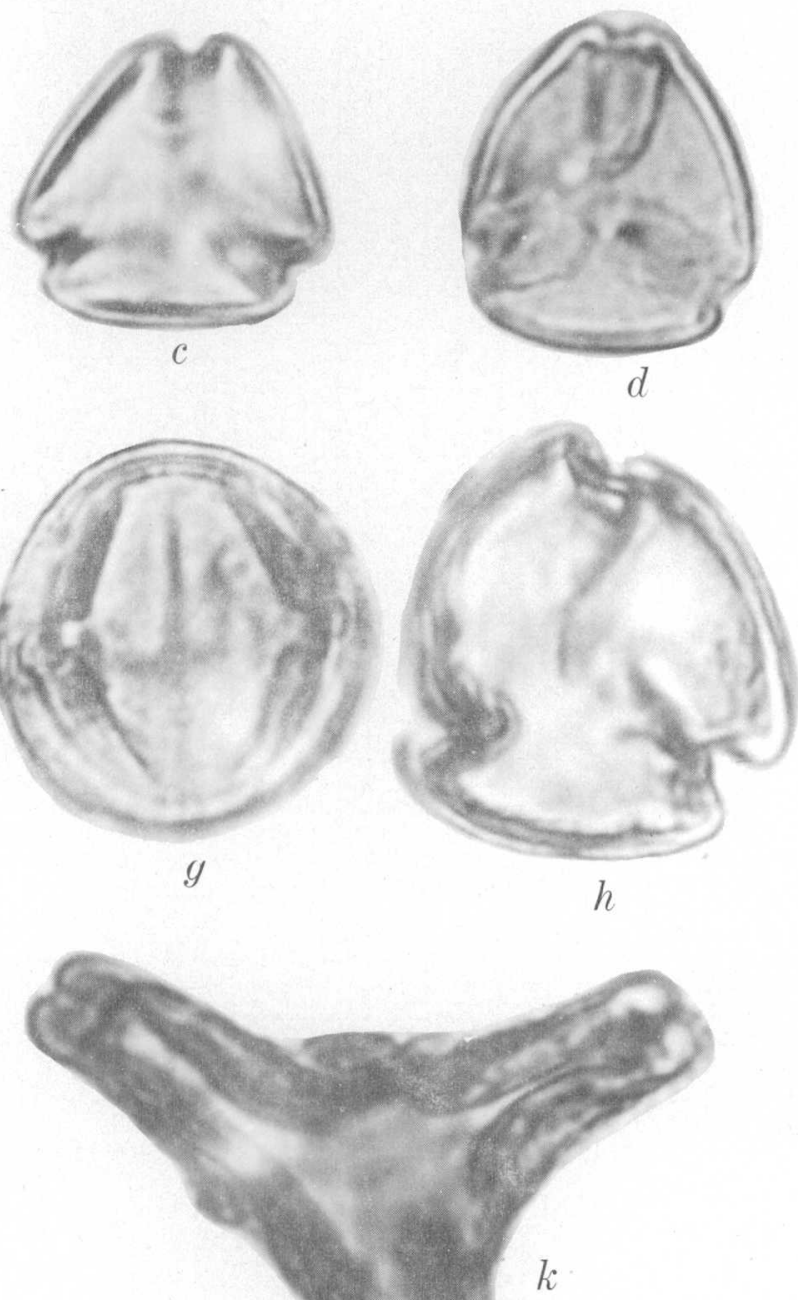
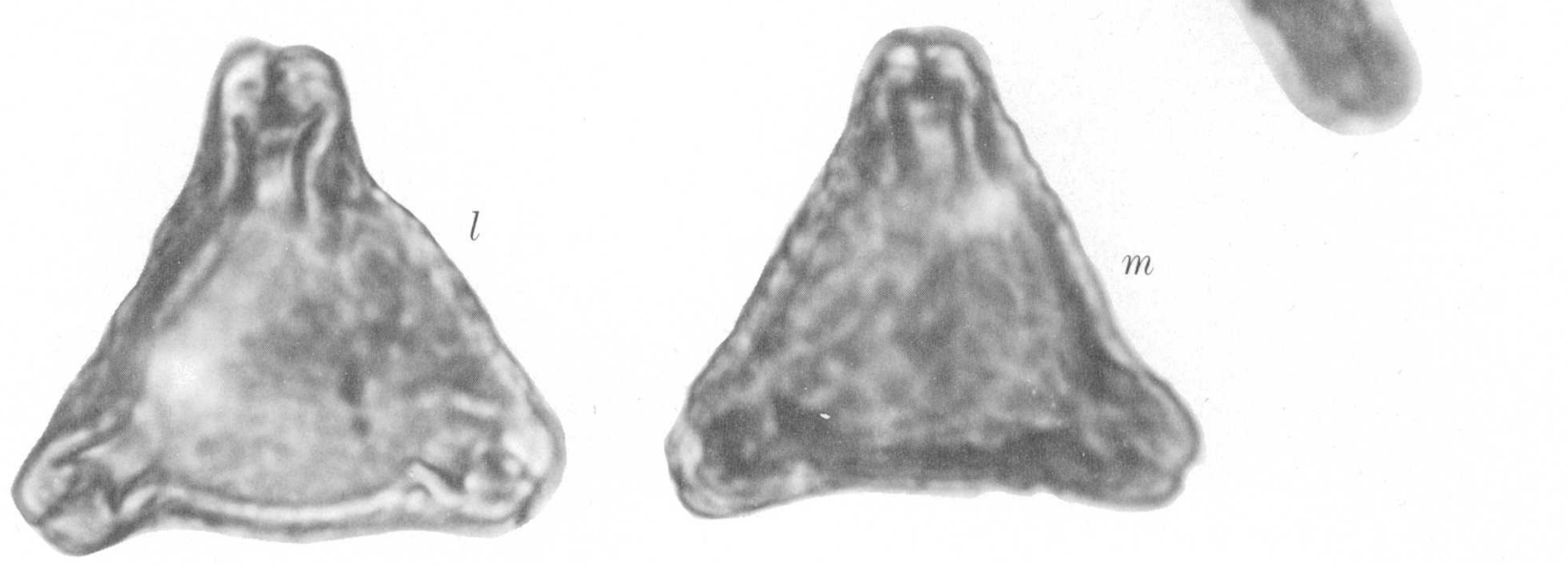

Figure 4.-Pollen from Garvies Point (Woodbridge Clay Member equivalent) $(a-i)$ and Block Island (South Amboy Fire Clay equivalent) $(j-m)$. Magnifications vary from $\times 1,000$ to $\times 1,500$.
a. Tricolporopollenites cf. T. triangulus.
f. Tricolporites $\mathrm{sp}$.
g. Tricolporites sp. (aff. Porocolpopollenites).
j. Tetrad (aff. Ericaceae).
$b, c$. Similar to, but slightly more convex than $a$.
h. Tricolporites $\mathrm{sp}$.
e. Tricolporites sp.
i. Tricolporites sp.
k. Atlantopollis sp.
l. Complexiopollis sp.
m. Complexiopollis sp. 


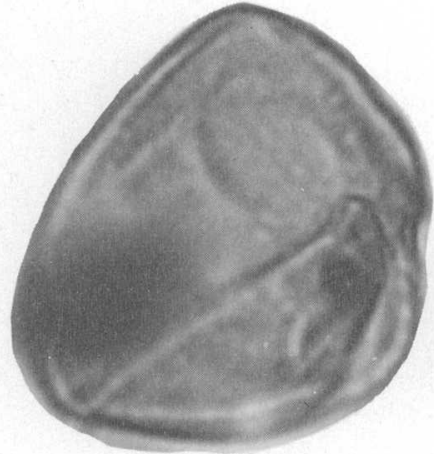

$a$

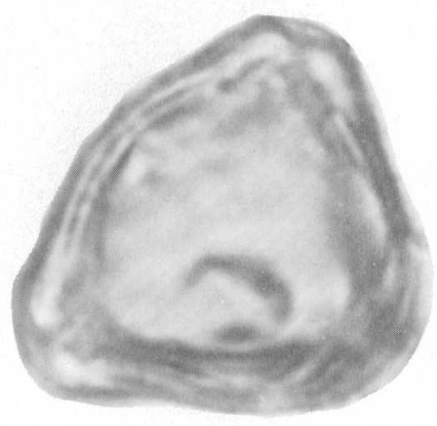

$e$

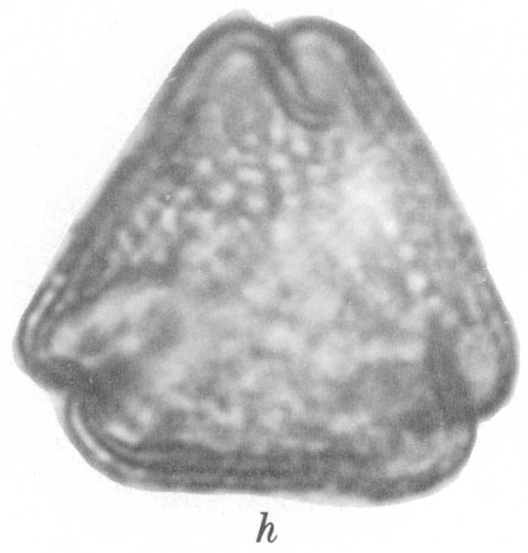

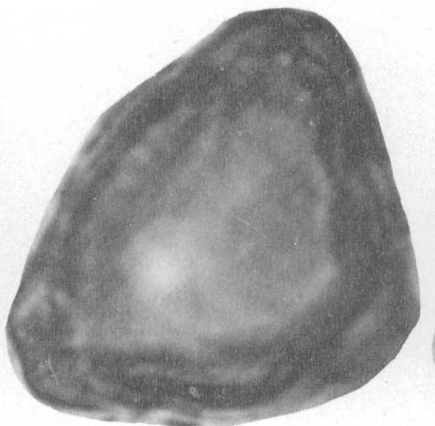

$b$

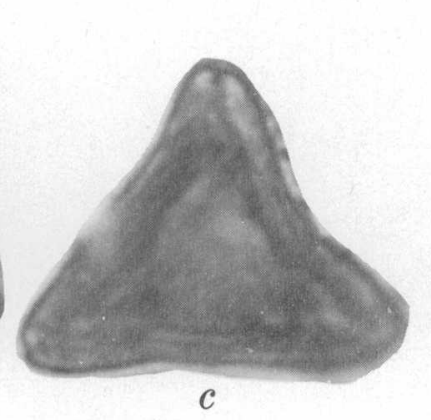

C

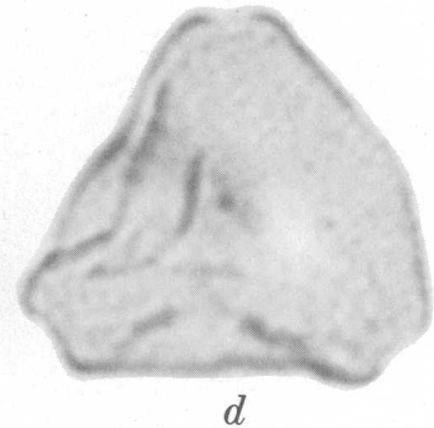

$d$

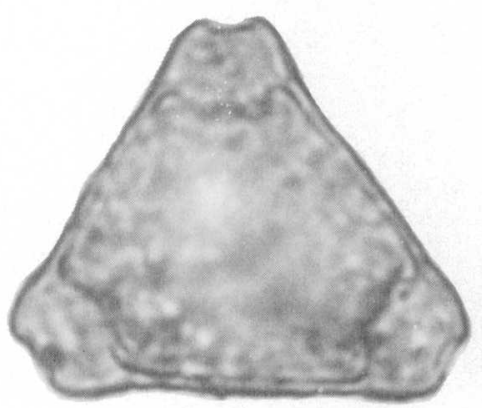

$f$

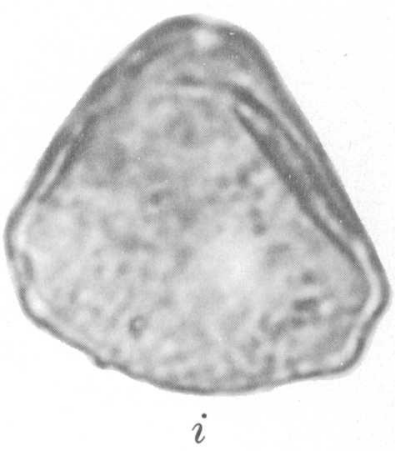

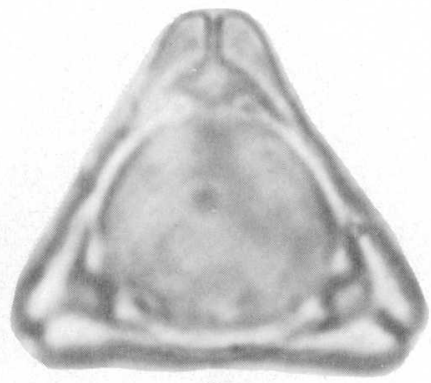

$g$

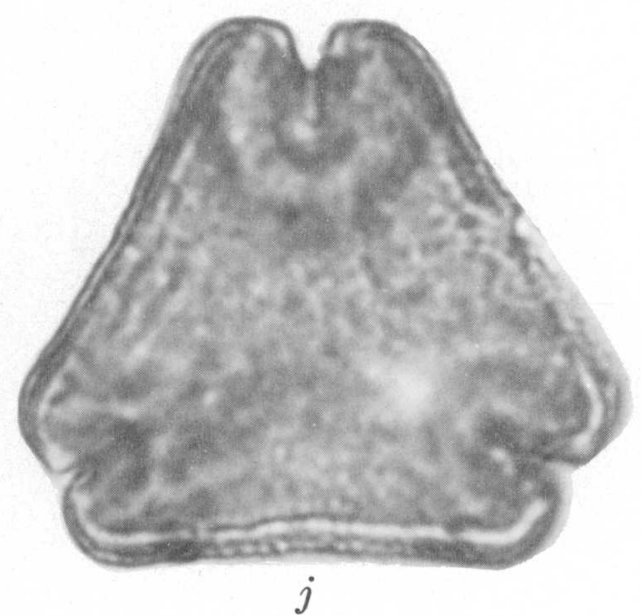

Figure 5.-Pollen from the Fire Island well S21,091T (South Amboy Fire Clay Member equivalent and Amboy Stoneware Clay Member equivalent); depth of recovery given. Magnifications vary from $\times 1,000$ to $\times 1,500$.

a. Complexiopolis (syn. Latipollis) sp.; 1,525 ft (462 m).

b. Triatriopollenites sp.; $1,545 \mathrm{ft}(4,68 \mathrm{~m})$.

c. Complexiopollis(?) sp.; $1,560 \mathrm{ft}(473 \mathrm{~m})$.

d. Proteacidites sp.; $1,560 \mathrm{ft}(473 \mathrm{~m})$.

e. Triatriopollenites $\mathrm{sp}$; $1,585 \mathrm{ft}(480 \mathrm{~m})$. f. Pecakipollis sp.; $1,585 \mathrm{ft}(480 \mathrm{~m})$.

g. Trudopollis sp.; $1,585 \mathrm{ft}(480 \mathrm{~m})$.

h. Tricolporites sp. (similar to type 6 of Doyle, 1969a); $1,585 \mathrm{ft}(480 \mathrm{~m})$.

$i$. Triatriopollenites $\mathrm{sp}$.; 1,800 ft (545 m).

j. Tricolporites sp. (similar to type 6 of Doyle, 1969a);1,800 ft (545 m).

\section{RESULTS}

Pollen and spores were recovered from sediments as deep as $1,873 \mathrm{ft}(571 \mathrm{~m})$ in the Fire Island well. These include 23 specimens, among which are both tricolporate and triporate pollen genera (fig. 5). Between 1,873 ft (571 m) and 1,800 ft
(549 $\mathrm{m}$ ), the same general assemblage is found along with the triporate, Atlantopollis, and additional tricolporates.

Between 1,786 ft (544 m) and 1,610 ft (491 m) fern spores and bisaccate gymnosperm pollen are relatively abundant; tricolporate and triporate pollen were not found. A profilic microflora occurs at $1,585 \mathrm{ft}(480 \mathrm{~m})$ and includes numerous 

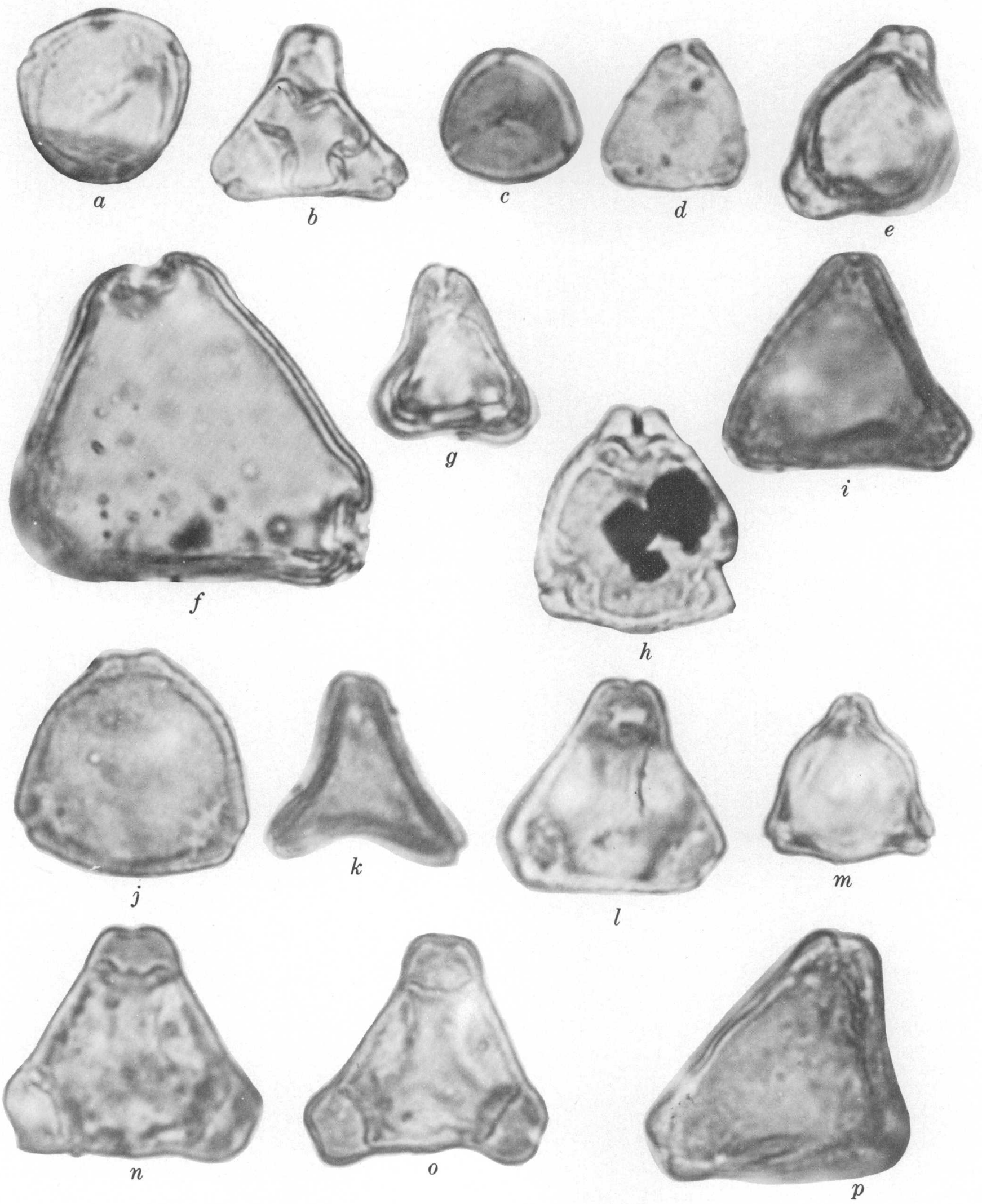

Figure 6.-Pollen from Fire Island well S21,091T (Magothy and Matawan-Magothy, undifferentiated); depth of recovery given. Magnifications vary from $\times 1,000$ to $\times 1,500$. 
spores and gymnosperms, of which inaperaturate forms and bisaccates, mainly Pinuspollenites and Podocarpidites, are common. At least 10 species of tricolporate pollen and 16 species of triporates occur in this assemblage. Although representation in all groups declines sharply from this depth up to $1,440 \mathrm{ft}(439 \mathrm{~m})$, both Atlantopollis and Praebasopollis are present.

Above 1,440 ft, few significant fossils were observed until $780 \mathrm{ft}(238 \mathrm{~m})$, where abundant triporates reappear. These include Coinplexiopollis, Minorpollis, Pecakipollis, Plicapollis, Praebasopollis, Proteacidites, Triatripollenites, Trudopollis, and two unknowns of small size and having simple pores. The number of specimens increases markedly near $780 \mathrm{ft}(238 \mathrm{~m})$, and most orders are abundant through the 240-ft (73-m) level. More than 200 specimens were counted at $665 \mathrm{ft}(203 \mathrm{~m})$, including many tricolporate and triporate species (fig. 6).

The dominance of dicotyledonous angiosperm pollen forms persists with only minor changes through the 240-ft (73-m) level. Tricolporate species are abundant at $580 \mathrm{ft}(117 \mathrm{~m}), 440$ $\mathrm{ft}(134 \mathrm{~m})$, and $260 \mathrm{ft}(79 \mathrm{~m})$, although triporates are the predominant form at $625 \mathrm{ft}(191 \mathrm{~m}), 595 \mathrm{ft}(181 \mathrm{~m}), 440 \mathrm{ft}$ $(134 \mathrm{~m})$, and $260 \mathrm{ft}(79 \mathrm{~m})$. The well section between $206 \mathrm{ft}$ $(63 \mathrm{~m})$ and $160 \mathrm{ft}(49 \mathrm{~m})$ contained little of stratigraphic value, only a few specimens being found at the $160 \mathrm{ft}(48-\mathrm{m})$ level.

On Long Island's north shore in the cliff section at Garvies Point, a lignite seam was sampled at approximately the high-tide level interbedded in a 4 -ft $(1.2-\mathrm{m})$ section with sands and clays (fig. 3). This seam contained an abundant microflora, of which spores, gymnosperms, and monosulcate and tricolpate pollen are very similar to those found in the lower part of the Fire Island core. Of significance in this sample is the abundance of the gymnosperm Rugubivesiculites, the monaperturate angiosperm Clavatipollenites, Typha-like tetrads, and tricolpate and tricolporate pollen. However, the presumed advanced forms were only occasionally found in the tricolporate group, which was dominated by the smaller triangular forms. Triporates were not observed in the samples analyzed. A similar lignite at Port Washington yielded a correlative microflora.

The Block Island samples, also from lignitic seams in the lower levels of two beach cliff sections, have been included in this study for comparison and correlation eastward (figs. 2,4, and 7). They contain abundant spores and pollen quite similar to those described for the midlevel of the Fire Island well. Of particular interest are the triporate forms, Complexiopollis, Atlantopollis, Pseudoplicapollis, and Triorites(?).

\section{DISCUSSION}

The presence of triporate pollen generally associated with the South Amboy Fire Clay Member at a depth of $1,873 \mathrm{ft}$ $(571 \mathrm{~m})$ indicates that the equivalent of the South Amboy Fire Clay Member of the Raritan Formation occurs relatively near the base of the Fire Island well (fig. 1). This unit, which has a more advanced microflora (figs. 5 and 7) than that of the Woodbridge Clay Member (Zone IV, fig. 4), is designated Zone $\mathrm{V}$. This microflora, and hence Zone $\mathrm{V}$, persists to the 1,800-ft (549-m) level. On the basis of this zonation, the lowermost clay horizon studied in the well is correlated with the South Amboy Fire Clay Member of the Raritan Formation in New Jersey.

The Woodbridge Clay Member, if present at all in this section, might be represented by a thin clay near $1,900 \mathrm{ft}$ (579 $\mathrm{m})$. However, the lower clay was not sampled. If this clay is a Woodbridge equivalent, then the underlying sand may represent the Farrington Sand Member of the Raritan Formation. The Garvies Point section, which lacks triporate pollen but contains the larger tricolporate forms, may be correlated with the Woodbridge Clay Member; that is, Zone IV. Regardless, the Early Cretaceous appears to be absent in the Fire Island well and in the north shore cliff sections studied thus far.

The sand section known as the Lloyd Sand Member of the Raritan Formation which occurs between 1,786 ft $(544 \mathrm{~m})$ and 1,610 ft (4.91 m) may correlate with the Old Bridge Sand Member of the Magothy Formation in New Jersey because it overlies the equivalent of the South Amboy Fire Clay Member section. However, this unit is relatively unfossiliferous and cannot be assigned with certainty to either the upper Raritan or the Magothy. In fact, this sand might have been considered significantly older on the basis of the presence of typical Early Cretaceous spores, gymnosperm pollen, and only one tricolporate specimen. Although a greater age would have been more in keeping with existing correlations, the establishment

Figure 6.-Continued.

a. Triatripollenites(?) sp.; $240 \mathrm{ft}(73 \mathrm{~m})$.

b. Trudopollis sp.; $260 \mathrm{ft}(81 \mathrm{~m})$.

c. Tricolporites sp.; $240 \mathrm{ft}(73 \mathrm{~m})$.

d. New genus $\mathrm{N}$ (after Wolfe and Pakiser, 1971); $260 \mathrm{ft}(81 \mathrm{~m})$.

e. Complexiopollis(?) sp.; $490 \mathrm{ft}(1.48 \mathrm{~m})$.

f. Proteacidites sp.; $490 \mathrm{ft}(148 \mathrm{~m})$.

g. New genus A (Aff. Praebasopollis, after Wolfe and Pakiser, $1971) ; 260 \mathrm{ft}(81 \mathrm{~m})$ h. Trudopollis sp.; $540 \mathrm{ft}(133 \mathrm{~m})$

i. Pecakipollis sp.; $695 \mathrm{ft}(212 \mathrm{~m})$.

j. Triatriopollenites sp.; $695 \mathrm{ft}(212 \mathrm{~m})$.

k. Complexiopollis sp.; $695 \mathrm{ft}(212 \mathrm{~m})$.

l. Plicapollis sp.; $725 \mathrm{ft}(220 \mathrm{~m})$.

m. Minorpollis sp.; $695 \mathrm{ft}(212 \mathrm{~m})$.

n. Plicapollis sp.; $695 \mathrm{ft}(212 \mathrm{~m})$.

o. Plicapollis sp.; $695 \mathrm{ft}(21.2 \mathrm{~m})$.

p. Complexiopollis sp.; $725 \mathrm{ft}(220 \mathrm{~m})$. 
of Zone $\mathrm{V}$ below the sand and VII above indicates that existing stratigraphic nomenclature may be extended into the Long Island region. Furthermore, the Block Island section which also contains the Zone $\mathrm{V}$ microflora may be correlated with the Upper Cretaceous South Amboy Fire Clay Member (Zone V).

Above $1,610 \mathrm{ft}(491 \mathrm{~m})$, tricolporate and triporate pollen that have definite Magothy, that is, Amboy Stoneware Clay Member (Zone VII), affinities enter the record. These include the more advanced tricolporates (types 5 and 6 of Doyle, 1969a) and triporates that would suggest correlation with the Amboy Stoneware Clay Member, whereas subsequent assemblages may be equated with the Morgan and Cliffwood beds of the Magothy Formation (fig. 2). This evidence indicates that the Magothy-Raritan boundary might be placed at a minimum depth of about $1,600 \mathrm{ft}(490 \mathrm{~m})$, a depth considerably lower than a previously determined lithologic boundary of $1,151 \mathrm{ft}(351 \mathrm{~m})$ (Nathaniel Perlmutter, oral commun., 1971). However, the Lloyd Sand-Old Bridge Sand Members correlation would place the boundary in the vicinity of $1,786 \mathrm{ft}(544 \mathrm{~m})$.

The "Magothy" microflora persists with only minor changes upward in the section to $1,440 \mathrm{ft}(439 \mathrm{~m})$, whereas between 1,440 and $1,225 \mathrm{ft}(373 \mathrm{~m})$ the pollen record is sparse. This section is of variable content, sand grading upward into clays and silts. It transgresses the previous "lithic" Lloyd SandRaritan boundary at $1,414 \mathrm{ft}(431 \mathrm{~m})$ (fig. 2). However, on the basis of lithology, within the limits set by the pollen record, Rhodehamel and Perry (written commun., 1973) placed the Amboy Stoneware Clay Member of the Magothy Formation in the interval between 1,360 and $1,414 \mathrm{ft}$ $(415-431 \mathrm{~m})$. If the Magothy-Raritan boundary were to be lowered to the maximum possible depth consistent with the lithologic and pollen evidence $(1,174 \mathrm{ft} ; 358 \mathrm{~m})$, the overlying stratigraphic units would also be adjusted in level or thickness. For example, the section between $1,174 \mathrm{ft}(358 \mathrm{~m})$, a possible top of the Magothy, and $224 \mathrm{ft}(68 \mathrm{~m})$, the base of the Monmouth, leaves $950 \mathrm{ft}(290 \mathrm{~m})$ for the Matawan sequence. This thickness is more than four times the measured thickness in New Jersey, as established by Owens and others (1970). However, zonation and correlation of the intervening strata $(1,420-780 \mathrm{ft} ;(439-238)$ is further complicated by lack of samples and pollen data.

The pollen content in the interval 780-240 $\mathrm{ft}(238-73 \mathrm{~m})$ differs in number of genera and species from the underlying Magothy (Zone VII) segment as designated in this study. The abundant microflora in the samples from 780-240 ft (238-73 $m$ ) is characterized by the advanced tricolporates and "Normapolles" triporates, which are associated with Magothy and younger Cretaceous horizons. However, the pollen assemblages do not contain triporate and polyporate forms (notably the form genera of Myrica, Ulmus, Juglans, Carya, and Alnus) which are more closely associated with latest Cretaceous or the Paleocene, as summarized by Tschudy and Scott (1969). This sequence may be included in the Matawan, even though greatly overthickened, until further evidence for the MagothyMatawan and Matawan-Monmouth boundaries can be established. (Current local terminology cites the MagothyMatawan undifferentiated, after Perlmutter and Todd, 1965.)

A Magothy-Matawan boundary should exist in the interval between 1,440 and $780 \mathrm{ft}(439-238 \mathrm{~m})$, if the probability is accepted that either unit may be considerably thicker here than in New Jersey. However, the section above $240 \mathrm{ft}(73 \mathrm{~m})$ contains too few pollen and spores to establish a MatawanMonmouth boundary. Until additional subsurface samples are available, the Matawan-Monmouth boundary remains as established by Perlmutter and Todd (1965) at about $240 \mathrm{ft}$ (73 m).

The more recent developments in Cretaceous palynology would indicate that the data presented in the Brookhaven well study by Steeves (1959) should be reinterpreted in order to provide some additional insight into the Upper Cretaceous stratigraphy on Long Island. For example, the complex microflora observed at the $400-\mathrm{ft}(121-\mathrm{m})$ level of the Brookhaven well includes about eight families of dicotyledenous angiosperms, which account for more than 82 percent of the pollen and spore sum, as well as acolpate and polyporate genera. Such a spectrum may be more associated with uppermost Cretaceous and Tertiary microfloras than with the Magothy (fig. 1). Furthermore, triporates represent 38 percent of the sum below $400 \mathrm{ft}(121 \mathrm{~m})$ and still constitute a significant representation at nearly $1,100 \mathrm{ft}(333 \mathrm{~m})$, whereas all angiosperms represent 75 percent at $1,050 \mathrm{ft}(320 \mathrm{~m})$ and 24 percent at $1,295 \mathrm{ft}(393 \mathrm{~m})$. Evidently, the RaritanMagothy boundary might be significantly lowered from the $400-\mathrm{ft}$ ( $121-\mathrm{m})$ level selected by Steeves, possibly well below $1,100 \mathrm{ft}(333 \mathrm{~m})$, a depth more compatible with the present study. A deeper location for this boundary was indicated in an electric-log study of the Brookhaven wells by deLaguna (1963), who placed the top of the Raritan Formation between $940 \mathrm{ft}(285 \mathrm{~m})$ and $975 \mathrm{ft}(296 \mathrm{~m})$ below sea level. The prevalence of triaperturate forms in the basal samples suggests that this section is also Late Cretaceous in age.

Application of the number-of-species concept of Wolfe and Pakiser (1971) to the present study is complicated by variations in generic and specific nomenclature, particularly as applied to new genera and the resulting species totals. However, Wolfe and Pakiser indicated an increase in number of triaperaturate pollen species in the Magothy from about 68 for the Amboy Stoneware Clay Member to 71 for the Morgan beds and 81 for the Cliffwood beds. In this study, a minimum of 13 species may be reported for the Woodbridge (Zone IV) equivalent strata, although only about 20 species were found in the South Amboy Fire Clay (Zone V) sediments, 37 in the Magothy, and 60 in the Magothy-Matawan. Although correlation of these data is marginal, species representation and total pollen frequency are generally lower in marine or subaqueous deltaic sediments than in continental samples, which in the Cretaceous frequently contain highly fossiliferous lignites. 


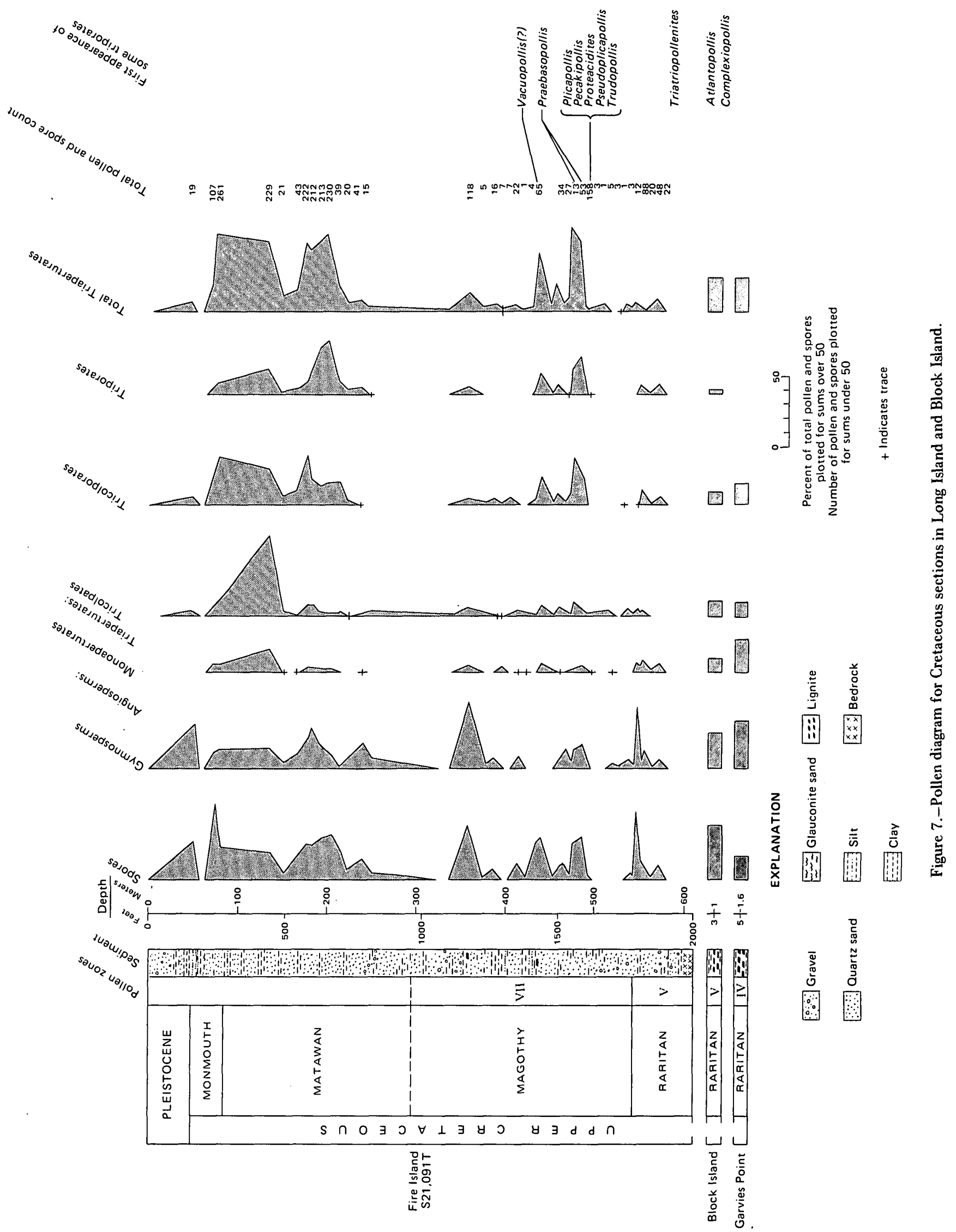




\section{CONCLUSIONS}

Palynologic evidence provides new interpretations of the Cretaceous stratigraphy in Long Island and Block Island. In Long Island, the entire section in a well in Fire Island has been shown to include Raritan through Monmouth units with upper Raritan ages assigned to the lowermost clay unit samples $(1,873 \mathrm{ft} ; 571 \mathrm{~m})$ in a $2,000-\mathrm{ft}(606-\mathrm{m})$ well section. The Lloyd Sand Member may be correlated with the Old Bridge Sand Member of the Magothy, for which the current stage determinations of Owens and others (1970) are retained (fig. 1).

Outcropping Cretaceous clays in the north shore of Long Island may represent depositional equivalents of the Woodbridge Clay Member in New Jersey. This section and underlying sediments may represent lower Upper Cretaceous units, which may not extend to the south shore in this region, or younger Cretaceous horizons over which the Woodbridge equivalent beds were shoved by the glaciers. Clays cropping out in northeastern and southeastern Block Island are shown to represent biostratigraphic equivalents of the South Amboy Fire Clay Member rather than the Magothy Formation. It may be concluded that the thickest remnants of Late Cretaceous deposition, as presently defined, occur in northeastern New Jersey and southwestern and south-central Long Island.

The Magothy- and Matawan-age sediments in the subsurface in Long Island are not readily subdivided as are the equivalent outcropping strata in New Jersey. These strata may represent subaqueous facies of the ancestral river delta, whereas the New Jersey sediments may represent the nonmarine or shoreline facies marginal to this delta.

In correlating Cretaceous strata from New Jersey to Long Island and then to Block Island through the pollen zonation, the continuity of some Cretaceous units is readily established. This regional continuity provides a framework to which the marine Cretaceous deposits that are believed to exist in the Continental Shelf may be identified. Further studies might be directed toward identifying the limits of the younger Cretaceous strata and the Cretaceous-Tertiary boundary in the shelf sequence.

\section{REFERENCES CITED}

Baskerville, C. A., 1965, A micropaleontological study of Cretaceous sediments on Staten Island: New York Univ., Ph. D. thesis; Ann Arbor, Mich., Univ. Microfilms, 65 p.

Brenner, G. J., 1963, The spores and pollen of the Potomac Group of Maryland: Maryland Dept. Geology, Mines, and Water Resources Bull. 27, 215 p.

deLaguna, Wallace, 1963, Geology of Brookhaven National Laboratory and vicinity, Suffolk County, New York: U.S. Geol. Survey Bull. 1156-A, p. A1-A35.

Dorf, Erling, 1952, Critical analysis of Cretaceous stratigraphy and paleobotany of the Atlantic Coastal Plain: Am. Assoc. Petroleum Geologists Bull. 36, no. 11, p. 2161-2184.

Doyle, J. A., 1969a, Cretaceous angiosperm pollen of the Atlantic Coastal Plain and its evolutionary significance: Arnold Arboretum Jour., v. 50, no. 1,35 p.

$1969 \mathrm{~b}$, Angiosperm pollen evolution and biostratigraphy of the basal Cretaceous formations of Maryland, Delaware, and New Jersey: Geol. Soc. America Abs. with Programs, [v. 1], pt. 7, p. 51.

Gill, H. E., Sirkin, L. A., and Doyle, J. A., 1969, Cretaceous deltas in the New Jersey Coastal Plain: Geol. Soc. America Abs. with programs, [v. 1], pt. 7, p. 79.

Gray, T. C., and Groot, J. J., 1966, Pollen and spores from the marine Upper Cretaceous formations of Delaware and New Jersey: Palaeontographica, v. 117, ser. B, nos. 4.6, p. 114-134.

Groot, J. J., and Groot, C. R., 1962, Plant microfossils from Aptian, Albian, and Cenomanian deposits of Portugal: Portugal Serviços Geol. Comun., v. 46, p. 133-171.

Groot, J. J., and Penny, J. S., 1960, Plant microfossils and age of nonmarine Cretaceous sediments of Maryland and Delaware: Micropaleontology, v. 6, no. 2, p. 225-236.

Groot, J. J., Penny, J. S., and Groot, C. R., 1961, Plant microfossils and age of the Raritan, Tuscaloosa, and Magothy formations of the eastern United States: Palaeontographica, v. 108, ser. B, nos. 3-6, p. $121-140$.

Kimyai, Abbas, 1966, New plant microfossils from the Raritan Formation (Cretaceous) in New Jersey: Micropaleontology, v. 12, no. 4 , p. $461-476$.

Leopold, E. B., and Pakiser, H. M., 1964, A preliminary report on the pollen and spores of the pre-Selma Upper Cretaceous strata of western Alabama: U.S. Geol. Survey Bull. 1160-E, p. 71-95.

Owens, J. P., Minard, J. P., and Sohl, N. F., 1968, Cretaceous deltas in the northern New Jersey coastal plain, in Finks, R. M., ed, Guidebook to field excursions, New York State Geol. Assoc., 40th Ann. Mtg., Flushing, N.Y., 1968: Brockport, N.Y., State Univ. Coll., Dept. Geology, p. 33-48.

Owens, J. P., Minard, J. P., Sohl, N. F., and Mello, J. F., 1970, Stratigraphy of the outcropping post-Magothy Upper Cretaceous formations in southern New Jersey and northern Delmarva Peninsula, Delaware and Maryland: U.S. Geol. Survey Prof. Paper $674,60 \mathrm{p}$.

Ownes, J. P., and Sohl, N. F., 1969, Shelf and deltaic paleoenvironments in the Cretaceous-Tertiary formations of the New Jersey Coastal Plain, in Subitzky, Seymour, ed., Geology of selected areas in New Jersey and eastern Pennsylvania and guidebook of excursions: New Brunswick, Rutgers Univ. Press, p. 235-278.

Perlmutter, N. M., and Todd, Ruth, 1965, Correlation and Foraminifera of the Monmouth Group (Upper Cretaceous), Long Island, New York: U.S. Geol. Survey Prof. Paper 483-I, 24 p., 6 pls.

Richards, H. G., 1943, Fauna of the Raritan Formation of New Jersey: Acad. Nat. Sci. Philadelphia Proc., v. 95, p. 15-32.

Steeves, M. W., 1959, Pollen and spores of the Raritan and Magothy Formations (Cretaceous) of Long Island: Cambridge, Harvard Univ., Ph. D. thesis, $169 \mathrm{p}$.

Stephenson, L. W., 1954, Additions to the fauna of the Raritan formation (Cenomanian) of New Jersey: U.S. Geol. Survey Prof. Paper 264-B, p. 25-43.

Tschudy, R. H., and Scott, R. A., eds., 1969, Aspects of palynology: New York, Wiley-Interscience Publishers, 510 p.

Tuttle, C. R., Allen, W. B., Hahn, G. W., 1961, A seismic record of Mesozoic rocks on Block Island, Rhode Island, in short papers in the geologic and hydrologic sciences: U.S. Geol. Survey Prof. Paper 424-C, p. C254-C256.

Wolfe, J. A., and Pakiser, H. M., 1971, Stratigraphic interpretations of some Cretaceous microfossil floras of the Middle Atlantic States, in Geological Survey research: U.S. Geol. Survey Prof. Paper 750-B, p. B35-B47.

Woodworth, J. B., 1934, Geology of Block Island, in Wood worth, J. B., and Wigglesworth, Edward, Geography and geology of the region including Cape Cod, the Elizabeth Islands, Nantucket, Martha's Vineyard, No Man's Land, and Block Island: Harvard Coll. Mus. Comp. Zoology Mem., v. 52, p. 212-219. 


\title{
ENERGY DISPERSIVE SPECTROMETRY FOR QUANTITATIVE MINERALOGICAL ANALYSES-AN ANCILLARY SYSTEM ON AN ELECTRON MICROPROBE
}

\author{
By GEORGE A. DESBOROUGH and ROBERT H. HEIDEL, Denver, Colo.
}

\begin{abstract}
Investigation of the Li-drifted Si-semiconductor X-ray detector for quantitative elemental analysis of some common rockforming minerals shows that a mounts of certain major elements having $K$ spectra in the energy range of about $1.74(\mathrm{Si})$ to $8.64(\mathrm{Zn})$ kiloclectronvolts may be accurately determined, if spectral interferences are absent. Elements in major concentrations between 0.5 and 1.00 percent may be analyzed quantitatively without corrections of $K$ spectra X-ray intensities when reference standards of similar composition are used and significant $K$ spectra interferences between two adjacent elements are absent. Elemental concentrations less than about 0.5 weight percent cannot be precisely determined from raw X-ray intensity data owing to high and variable spectral background. Data show that spectral background corrections are feasible because spectral background is a linear function for the light-element oxides and silicates. Simultaneous quantitative elemental analysis, with both the energy dispersive spectrometer and the conventional wavelength dispersive spectrometers on the electron microprobe, is feasible.
\end{abstract}

The Li-drifted Si-semiconductor detector used as an ancillary system on an electron microprobe permits microanalysis of several elements simultaneously and thereby increases the analytical capability of the microprobe. Applications of energy dispersive spectrometer (EDS) systems used on both electron microprobes and scanning microscopes were first reported on comprehensively in the 1970 symposium "Energy Dispersion X-ray Analysis: X-ray and Electron Probe Analysis" sponsored by the American Society for Testing and Materials (1971). More recently Beaman and Isasi (1972, p. 14-29) provided a detailed outline and summary of the characteristics and performance of EDS systems used on electron beam instruments. The principal use of the EDS systems has been qualitative or semiquantitative analysis, and few, if any, data have been published on the applications to quantitative multiple-element analysis of complex materials such as the common rock-forming minerals.

The Li-drifted Si-semiconductor detector is an energy dispersive spectrometer (EDS) in contrast with a wavelength dispersive spectrometer (WDS) on a conventional electron microprobe. The main advantages of an EDS system over a
WDS are the added analytical capability, relatively low cost, and adaptability to (and lack of interference with) existing electron microprobe systems.

Myklebust and Henrich (1.971) pointed out the singlechannel-analyzer approach in quantitative electron probe analysis with an EDS system, but presented no experimental data on mineralogical applications.

Beaman and Solosky (1972) summarized the accuracy of energy dispersive spectrometers in electron microprobe analysis and concluded that "if the concentration is greater than about 20 weight percent, a relative error of \pm 6 percent of the amount present could be expected" and much larger errors are found at lower concentrations. Their data had already been corrected, by the classical correction scheme that uses atomic number, absorption, and fluorescence. In spite of these X-ray intensity corrections, their relative errors appear to be much greater than those found in our investigations where no X-ray intensity or background corrections are used. A major difference between our EDS system and others is our use of nine single-channel pulse height analyzers (SCA) rather than one multichannel analyzer (MCA) as most laboratories use in their readout systems. This SCA readout system, because of its simplicity and lower cost, is, in our opinion, more desirable that the MCA system. Using an SCA readout, raw count data may be handled in the same way as data obtained from the scalers of the electron microprobe.

Recently we reported (Desborough and Heidel, 1973) on the following aspects of our EDS system: (1) the design, configuration, and general specifications for the system, (2) the quantitative analytical capability of the energy dispersive spectrometer for a few simple multiple-element compounds (Ni-Fe, Au-Ag, and $\mathrm{Cd}-\mathrm{Zn}-\mathrm{S}$ ), using multiple single-channel analyzers, and (3) certain aspects of detector performance, with evaluation of peak-to-background ratios, sensitivity, precision, and detection limits for different electronmicroprobe operating conditions.

In the present paper, data are reported for the quantitative analytical capability of the energy dispersive spectrometer 
used in the minerals study that employs simultaneous multiple-element data collection with the energy dispersive spectrometer.

\section{ESSENTIAL TERMINOLOGY}

The X-ray energy spectra are referred to in electronvoltselectronvolts or kiloelectronvolts-whereas the familiar wavelength spectra are referred to in angstroms. The energy and wavelength spectra for all elements are tabulated in the "Handbook of Chemistry and Physics" (Weast, 1969, p. E147-E184).

The energy-discrimination ability of the EDS detector is called resolution and is generally stated in terms of electronvolts. Resolution is measured by determining "the total energy spread in a particular X-ray line at [full width] one-half maximum intensity (FWHM) measured after the accumulation of a large number of counts at a low total spectrum counting rate" (Beaman and Isasi, 1972, p. 15). In other words, the $\mathrm{X}$-ray width of the $K \alpha$ line of a pure metal (typically, Mn, Fe, or $\mathrm{Co}$ ) is measured at one-half the total intensity of the line for a fixed counting period. The highest resolution in EDS detectors now used for microanalysis typically ranges from about 150 to $220 \mathrm{eV}$ FWHM at $5.9 \mathrm{keV}(\mathrm{MnK} \alpha)$. The measured resolution of the detector used for this study is 169 $\mathrm{eV}$ FWHM for $\mathrm{Mn} K \alpha(5.90 \mathrm{keV})$ using a radioisotope source. The resolution of the detector is of prime importance inasmuch as this parameter determines the limitations of the system in terms of spectral interferences. Most of the subsequent terminology used in conjunction with the energy dispersive spectrometer (EDS) follows that of Beaman and Isasi (1972).

\section{QUANTITATIVE ENERGY DISPERSIVE SPECTROMETER ANALYSIS OF MINERALS}

We have selected some mineral series and (or) their synthetic equivalent materials to illustrate the quantitative analytical capability of the energy dispersive spectrometer. Data are presented herein, for purposes of EDS system evaluation, for some common sulfides, oxides, and silicates. Conditions of electron microprobe and EDS system operation are specified for each mineral group analyzed. All X-ray intensity data presented in the illustrations are in raw counts. Corrections of $\mathrm{X}$-ray intensity (counts) have not been made for background or other effects. Values of one standard deviation $(\sigma)$ have been determined and are based on 10 observations taken at different spots on each reference standard. The magnitude of these $\sigma$ values is stated in the text and (or) it is shown on the illustrations. In order to evaluate linearity of the relationship weight percent versus X-ray intensity (in counts) for each element, in a mineral suite or group, we have used simple regression analysis with $\mathrm{X}$-ray intensity as the dependent variable and thereby obtained two $\sigma$ values (95-percent confidence) of the standard error of estimate of the regression equation in terms of weight percent. This procedure naturally incorporates deviations from linearity of counts versus weight percent resulting from effects of background, absorption, atomic number, and fluorescence on X-ray intensity but should not reflect slight inhomogeneity in some reference standards which are natural minerals.

\section{Fe-Zn-S}

Data obtained for synthetic sphalerites using the energy dispersive spectrometer and two single-channel analyzers simultaneously for analysis of iron and zinc are shown in figure 1. Sulfur was also measured but is not shown, because the total range in concentration is only 1.5 percent. Data are for raw counts and are thus uncorrected for background. Concentration plotted against X-ray intensity is nearly linear, with the exception of zinc in pure $\mathrm{ZnS}$, and this is duc to lack of absorption by $\mathrm{Fe}$ present in the other samples. Values of coefficient of variation ( $C=\sigma / X$, where $X$ is the mean) for $\mathrm{Fe}$ range from 6.0 percent for 0.58 weight percent to 3.0 percent for 26.98 weight percent. For zinc, $C$ values range from 1.4 to 3.0 percent. These values of $C$, of course, also reflect some sample inhomogeneity. Values of $C$ for sulfur (not illustrated) range from 0.6 to 2.2 percent. Two $\sigma$ for the standard error of estimate of the regression equation of the $\mathrm{Fe}$ line (fig. 1) corresponds to \pm 0.21 weight percent for the 0 - to 27 -percent concentration range. Two $\sigma$ for the regression equation of the $\mathrm{Zn}$ line corresponds to \pm 1.27 weight percent for the 39 - to 67 -percent concentration range.

\section{Ti-Cr-Fe in oxides}

$\mathrm{X}$-ray intensity data versus weight percent concentration of $\mathrm{Ti}, \mathrm{Cr}$, and $\mathrm{Fe}$ are shown (fig. 2) for natural $\mathrm{TiO}_{2}$, four

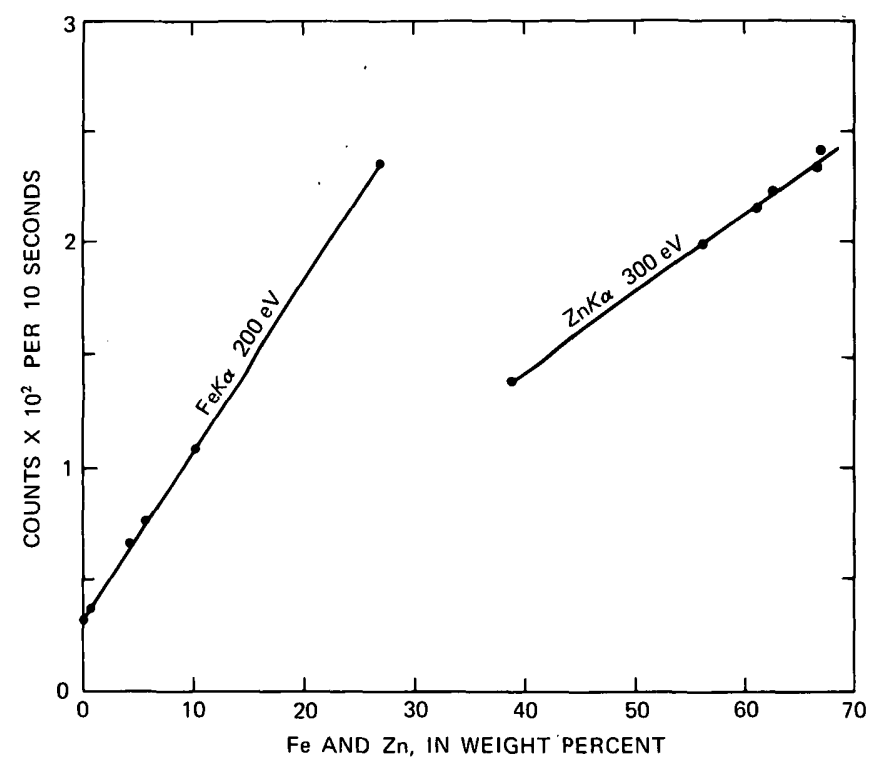

Figure 1.-Intensity data for synthetic sphalerites (Fe-Zn-S) for simultaneous readings for iron and zinc on two single-channel analyzers. Data points are the mean number of counts for 10 observations. Operating voltage, $15 \mathrm{kV}$; sample current, $6.25 \mathrm{nA}$. 
chromites, two ilmenites, one Ti-magnetite and synthetic hematite and magnetite. X-ray intensity data obtained simultancously on three single-channel analyzers are for raw counts. Values of cocfficient of variation $(C)$ for all points in figure 2 range from 1.4 to 3.8 percent for concentrations above 10 weight percent of $\mathrm{Ti}, \mathrm{Cr}$, and $\mathrm{Fe}$. The high $C$ values are due to the slight inhomogeneity of some natural samples, because $C$ values for $\mathrm{TiO}_{2}$ and synthetic $\mathrm{Fe}_{2} \mathrm{O}_{3}$ and $\mathrm{Fe}_{3} \mathrm{O}_{4}$ are loweronly 1.4 to 2.1 percent. Two $\sigma$ for the regression equations of the $\mathrm{Ti}, \mathrm{Cr}$, and $\mathrm{Fe}$ lines in figure 2 correspond to \pm 1.49 (Ti), \pm 0.51 . ( $\mathrm{Cr}$ ), and $\pm 1.35(\mathrm{Fe})$ for the concentration ranges 0 to $60 \mathrm{Ti}, 0$ to $33.5 \mathrm{Cr}$, and 0 to $72.5 \mathrm{Fe}$, all in weight percent.

Data for $2.5 \mathrm{nA}, 15 \mathrm{kV}$, and 20 -s counts on the same samples are similar and so are therefore not illustrated. Values of two $\sigma$ for the regression equations of $\mathrm{Ti}, \mathrm{Cr}$, and $\mathrm{Fe}$ lines correspond to \pm 1.49 (Ti), $\pm 0.56(\mathrm{Cr})$, and \pm 1.57 ( Fe) for the same concentration ranges as above.

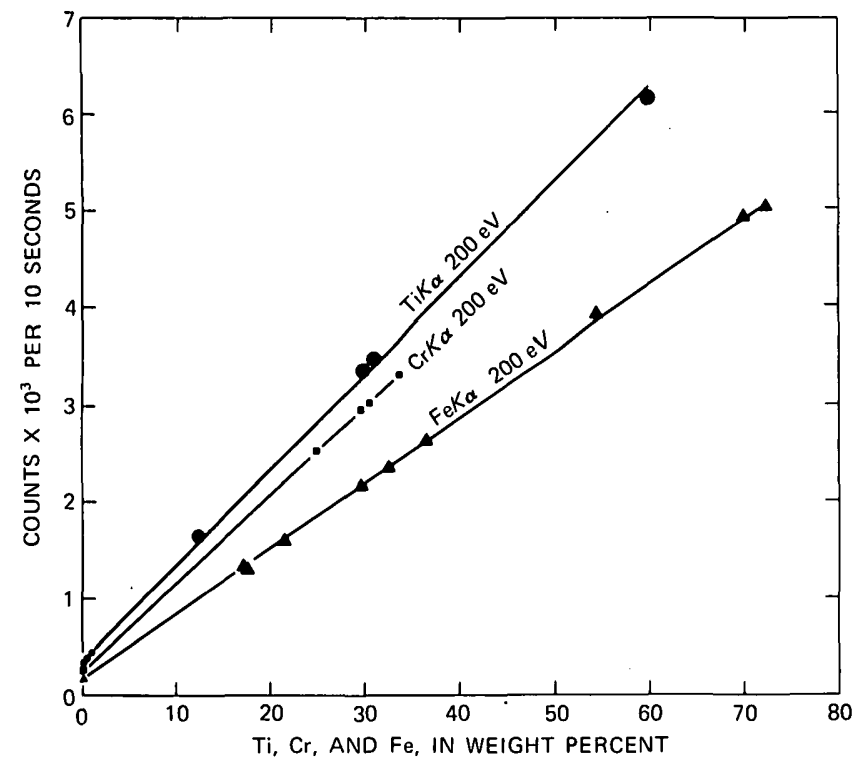

Figure 2.-Intensity data for Ti-Cr-Fe oxides with simultaneous readings for titanium, chromium, and iron in natural $\mathrm{TiO}_{2}$, four chromites, two ilmenites, one Ti-magnetite and synthetic hematite and magnetite on three single-channel analyzers. Each point represents the mean of 10 observations on each sample. Operating voltage, $1.5 \mathrm{kV}$; sample current, $5 \mathrm{nA}$.

\section{$\mathrm{Ca}$ and $\mathrm{Si}$ in light silicates}

Figure 3 illustrates data obtained on certain common silicates. X-ray intensity is in raw counts. Values for $1 \sigma$, in counts, are shown by vertical lines for Si. For Ca the diameter of the points is equivalent to $2 \sigma$. Two $\sigma$ for the regression equations of the $\mathrm{Si}$ and $\mathrm{Ca}$ lines in figure 3 correspond to \pm 2.48 (Si) and \pm 1.08 (Ca) weight percent, respectively for the concentration ranges studied which are in weight percent metals-not oxides. Note that these concentration ranges more than cover the entire range of $\mathrm{Ca}$ and $\mathrm{Si}$ in feldspars.

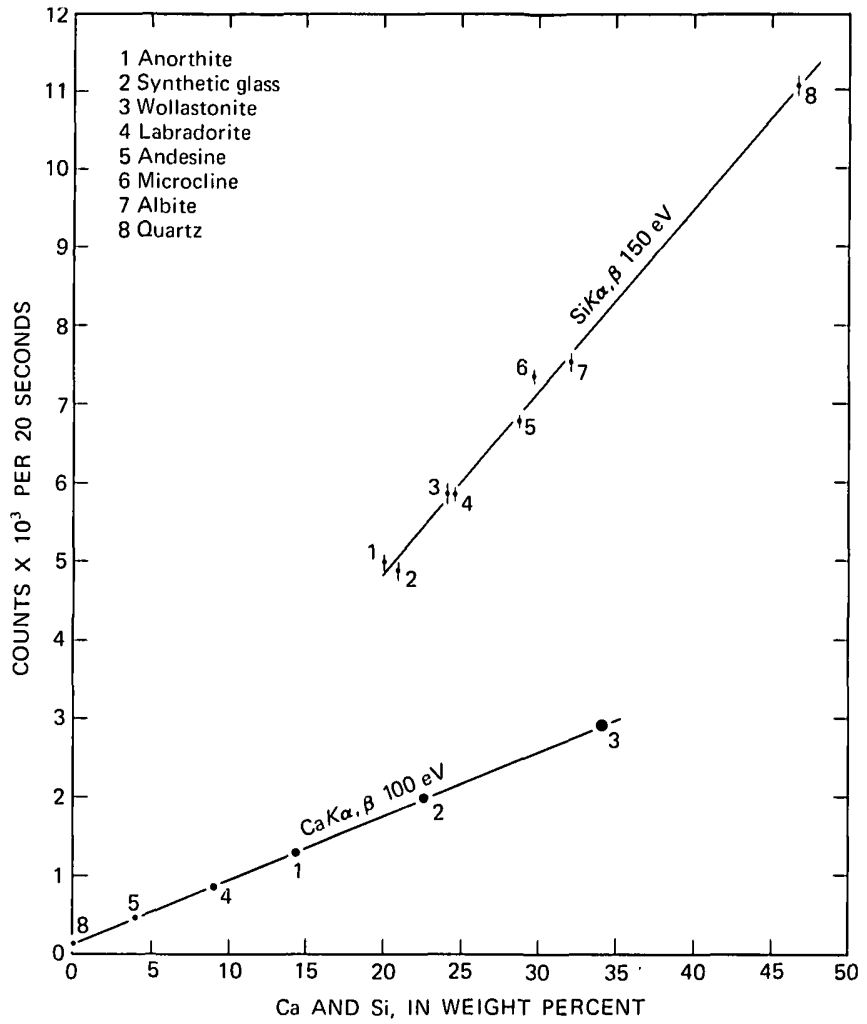

Figure 3.-Intensity data on eight common silicates for silicon and calcium read simultancously on two single-channel analyzers. Each point represents the mean of 10 observations on each sample. Operating voltage, $10 \mathrm{kV}$; sample current, $5 \mathrm{nA}$.

\section{$\mathrm{FeO}$ and $\mathrm{SiO}_{2}$ in silicates}

Simultaneous determination of iron and silicon in a variety of common silicates and glasses ranging from fayalite to quartz are illustrated in figure 4. Values of $1 \sigma$, in counts, are shown for each point and data are for raw counts. Two $\sigma$ values determined from the regression equations of the $\mathrm{SiO}_{2}$ and $\mathrm{FeO}$ lines correspond to $\pm 2.38\left(\mathrm{SiO}_{2}\right)$ and $\pm 1.55(\mathrm{FeO})$, respectively, in weight percent for the concentration ranges shown in figure 4.

\section{SIMULTANEOUS QUANTITATIVE ENERGY AND WAVELENGTH DISPERSIVE ANALYSES}

A major incompatibility problem in simultaneous EDS and WDS analyses is the substantial difference in beam current used for each type. Typically, for WDS analysis most electron microprobes are operated at greater than $30 \mathrm{nA}$ of specimen current, whereas for EDS analysis the microprobes are operated at 2 to $10 \mathrm{nA}$ (Beaman and Isasi, 1972). At the higher specimen currents, the EDS detectors are overloaded with counts, peak-to-background ratios decrease, and resolution is lost. This is especially true for detectors with thin (0.5-2 mil) Be windows. On the other hand, severe absorption 


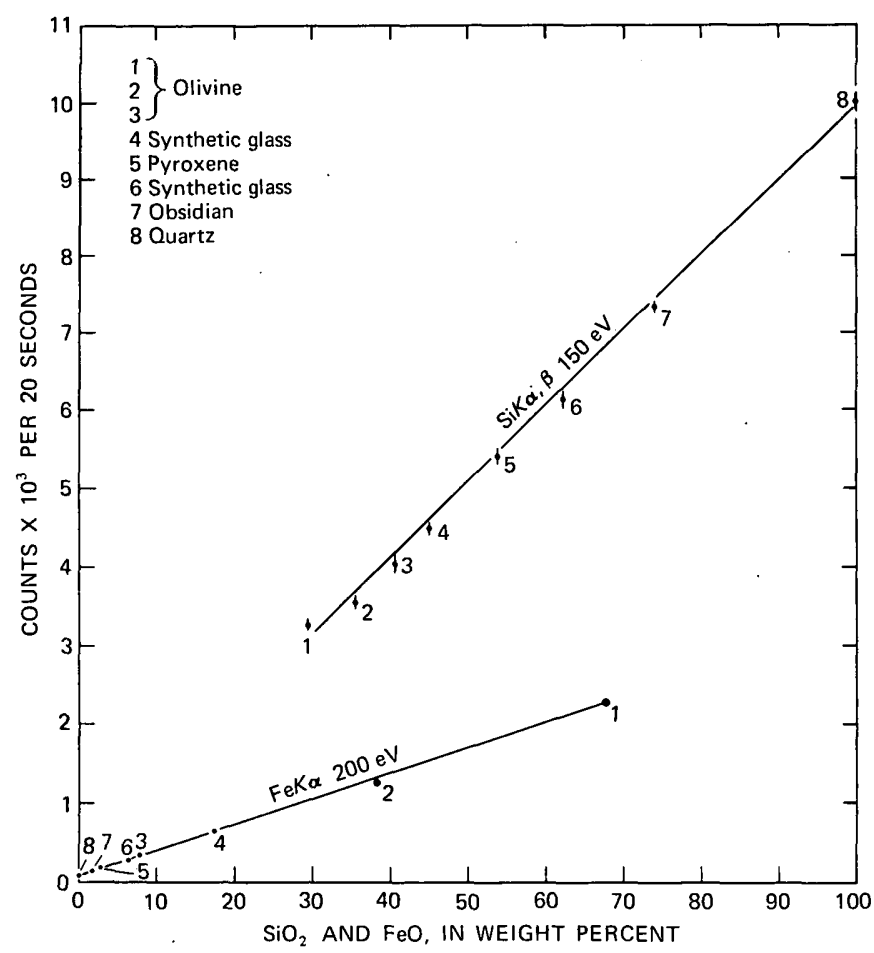

Figure 4.-Intensity data for the simultaneous determination of iron and silicon with two single-channel analyzers in common silicates ranging from fayalite, $(\mathrm{Fe}, \mathrm{Mn})_{2} \mathrm{SiO}_{4}$, to quartz, $\mathrm{SiO}_{2}$. Each point represents the mean of 10 observations on each sample. Operating voltage, $10 \mathrm{kV}$; sample current, $5 \mathrm{nA}$.

of $\mathrm{Na}, \mathrm{Mg}$, and $\mathrm{Al}$, by even a thin $(0.5 \mathrm{mil})$ beryllium detector window, precludes efficient detection of their $K$ spectra. In addition, the severe $K$ spectra interferences between $\mathrm{Na}, \mathrm{Mg}$, $\mathrm{Al}$, and $\mathrm{Si}$ may prohibit simultaneous quantitative analyses where two adjacent elements (for example, $\mathrm{Mg}$ and $\mathrm{Al}$ or $\mathrm{Al}$ and $\mathrm{Si}$ ) are both present in concentrations above about 20 weight percent. Interferences of $K$ spectra occur between $\mathrm{Na}$ and $\mathrm{Mg}, \mathrm{Mg}$ and $\mathrm{Al}, \mathrm{Al}$ and $\mathrm{Si}$ or $\mathrm{K}$ and $\mathrm{Ca}$ when any pair of these adjacent elements are present in similar concentrations above about 2 weight percent. Thus quantitative analysis of both elements may not be possible unless X-ray intensity corrections are made. In practice, however, both $\mathrm{Si}$ and $\mathrm{Ca}$ may be quantitatively determined in many common silicates where the $\mathrm{Al}$ and $\mathrm{K}$ concentrations are comparatively low. Concentrations of 0.5 to 2.0 weight percent of $\mathrm{K}$ cannot be accurately determined in the presence of 5 to 10 weight percent of Ca without X-ray intensity corrections, because of the high spectral background on the low-energy side of the Ca-K line. Similarly, low Al concentrations cannot be readily determined in the presence of minor $\mathrm{Si}$. In general, where spectral interferences occur between two adjacent elements which are both present in concentrations above 1 weight percent, the element of higher $K$ spectral energy can be more accurately determined without X-ray intensity corrections than can the adjacent element of lower $K$ spectral energy. This increased accuracy results from much higher X-ray intensity for "background" on the low-energy side of the peak than on the high-energy side, as shown in spectral scans (Lifshin, 1971, fig. 3; Bender and Duff, 1971, fig. 3).

Because of these absorption and $K$ spectra interferences, quantitative determination of the light elements (especially $\mathrm{Na}, \mathrm{Mg}$, and $\mathrm{Al}$ ) requires the WDS system of the electron microprobe. Thus we used low specimen currents for both WDS and EDS analyses, despite some sacrifice in count rates for the WDS system. This technique permits simultaneous quantitative determination of several major elements, using both systems.

The general approach is that the heavier elements commonly present in silicates such as $\mathrm{Si}, \mathrm{Ca}, \mathrm{Ti}, \mathrm{Cr}, \mathrm{Mn}$, and $\mathrm{Fe}$ may be determined simultaneously with the EDS system if they are present in concentrations above about 0.5 weight percent. Examples of simultaneous EDS and WDS use for some common rock-forming minerals are given in table 1 .

Table 1.-Spectrometer utilization for simultaneous energy dispersive spectrometer (EDS) and wavelength dispersive spectrometer (WDS) quantitative analysis, with an electron microprobe, of major elements of rock-forming minerals

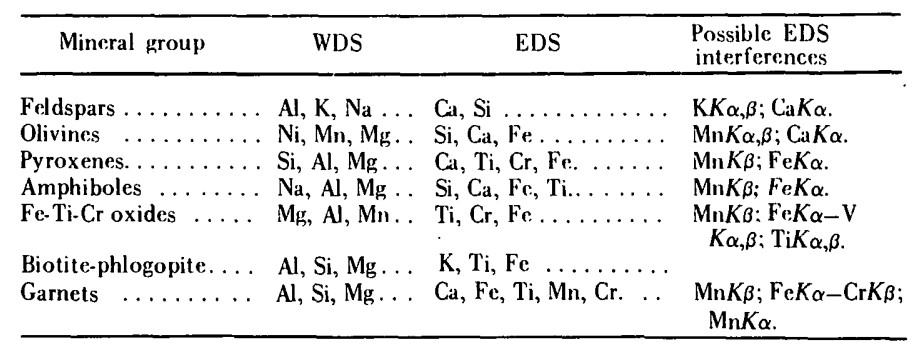

Data were abtained with the conventional electron microprobe wavelength dispersive spectrometers for evaluation of sensitivity and precision for low concentrations of $\mathrm{Mg}$ and $\mathrm{Al}$ and a wide range in concentration of $\mathrm{Si}$ using a sample current of $5 \mathrm{nA}$ (table 2). These data illustrate the compatibility of simultaneous analysis, using the WDS system for the lighter elements.

\section{SPECTRAL BACKGROUND}

Extreme variations in spectral background impose severe problems when raw intensity data are used for quantitative determination of minor constituents. The principal factor contributing in spectral background differences appears to be average atomic number $(\bar{Z})$ effects for the light-element oxides and silicates. Data were collected (fig. 5) at two energy regions $(5.2 \pm 0.075$ and $8.0 \pm 0.100 \mathrm{keV})$ for five simple oxides (MgO, $\mathrm{Al}_{2} \mathrm{O}_{3}, \mathrm{SiO}_{2}, \mathrm{TiO}_{2}$, and $\mathrm{Fe}_{2} \mathrm{O}_{3}$ ), nine multiple-element silicate minerals and glasses, and four glasses made from well-known bulk rocks fused 1:1 with lithium tetraborate. Data were obtained by taking 100 -s counts at both $15 \mathrm{kV}, 5 \mathrm{nA}$, and 10 $\mathrm{kV}, 5 \mathrm{nA}$, referenced to quartz.

Reference standards and the two energy ranges studied were selected solely on the basis of avoiding major spectral lines. 
Table 2.-Sensitivity (counts per weight percent)and precision ( $\pm \sigma$ in weight percent) for $\mathrm{Si}, \mathrm{Al}$, and $\mathrm{Mg}$ on fused samples and quartz for wavelength dispersion analysis

[Sample current, $5 \mathrm{nA}$; operating voltage, $10 \mathrm{kV}$ ]

\begin{tabular}{|c|c|c|c|c|c|c|c|c|c|}
\hline \multirow{2}{*}{ Sample } & \multicolumn{3}{|c|}{ Silicon } & \multicolumn{3}{|c|}{ Aluminum } & \multicolumn{3}{|c|}{ Magnesium } \\
\hline & $\begin{array}{l}\text { Wt percent in } \\
\text { standard }\end{array}$ & Precision & Sensitivity & $\begin{array}{l}\text { Wt percent in } \\
\text { standard }\end{array}$ & Precision & Sensitivity & $\begin{array}{l}\text { Wt percent in } \\
\text { standard }\end{array}$ & Precision & Sensitivity \\
\hline $1 \ldots$ & 46.75 & \pm 0.98 & 66.4 & $\ldots$ & $\ldots$ & & $\cdots$ & & $\ldots \ldots$ \\
\hline $2 \ldots \ldots$ & 12.25 & \pm .76 & 67.2 & 3.96 & \pm 0.02 & 65.8 & 1.99 & \pm 0.11 & 112.1 \\
\hline $3 \ldots \ldots$ & 20.37 & \pm .84 & 67.9 & 2.20 & \pm .12 & 69.1 & .28 & \pm .04 & 109.3 \\
\hline $4 \ldots \ldots$ & 9.62 & \pm .31 & 69.2 & 9.62 & \pm .20 & 69.3 & .45 & \pm .08 & 102.2 \\
\hline $5 \ldots \ldots$ & 9.89 & \pm .32 & 65.4 & 2.46 & \pm .16 & 69.9 & .78 & \pm .08 & 106.4 \\
\hline
\end{tabular}

Data points for the energy range of $5.2 \pm 0.075 \mathrm{keV}$ are not shown for $15 \mathrm{kV}$, because they merge with the low $(\bar{Z})$ values obtained for $8.0 \pm 0.100 \mathrm{keV}$ and also because spectral line interference occurs for $\mathrm{TiO}_{2}(\bar{Z}=16.4), \mathrm{Fe}_{2} \mathrm{O}_{3}(\bar{Z}=18.2)$, and fayalite $(\bar{Z}=18.67)$. (Data for the same materials and energy ranges use a sample current of $2.5 \mathrm{nA}$ at 10 and $15 \mathrm{kV}$ but show the same general relationships and are not plotted in fig. 5.) Vertical lines through each data point in figure 5 express the expected counting error $(\sqrt{ } n)$. Regression analysis was done for each of the three groups of spectral background data points (fig. 5) with spectral background counts as the dependable variable. Values at $2 \sigma$ (95-percent confidence) expressed in terms of $\bar{Z}$ are as follows:

$10 \mathrm{kV}-8.0 \pm 0.100 \mathrm{keV}= \pm 1.1(\bar{Z})$, $10 \mathrm{kV}-5.2 \pm 0.075 \mathrm{keV}= \pm 1.2(\bar{Z})$,

and $15 \mathrm{kV}-8.0 \pm 0.100 \mathrm{keV}= \pm 1.0(\bar{Z})$,

Figure 5 illustrates a systematic relationship between spectral background and average atomic number $(\bar{Z})$, and X-ray intensity corrections may therefore be made to determine spectral background for the light-element oxides and common silicates. Alternatively, one single-channel analyzer might be used exclusively to estimate $\bar{Z} \pm 1$ for the range $\bar{Z}$ equals 9 to 19, which includes virtually all the major rock-forming silicates and oxides. Such corrections for spectral background would, of course, improve detection limits.

\section{HIGHER COUNT RATES WITH PULSED OPTICAL FEEDBACK}

All data presented herein were obtained with a detector not equipped with a pulsed optical feedback system. Subsequent addition of the pulsed optical system permitted much higher EDS counting rates, and therefore higher microprobe beam currents, without resulting dead-time losses due to detector overload.

The most straightforward method of evaluation of X-ray intensity loss due to dead time for a given operating condition is to determine the linearity of observed $\mathrm{X}$-ray intensity for a spectral peak versus sample current. The most rigorous test is performed on metals or simple oxides such as $\mathrm{Si}, \mathrm{SiO}_{2}, \mathrm{Ti}$,

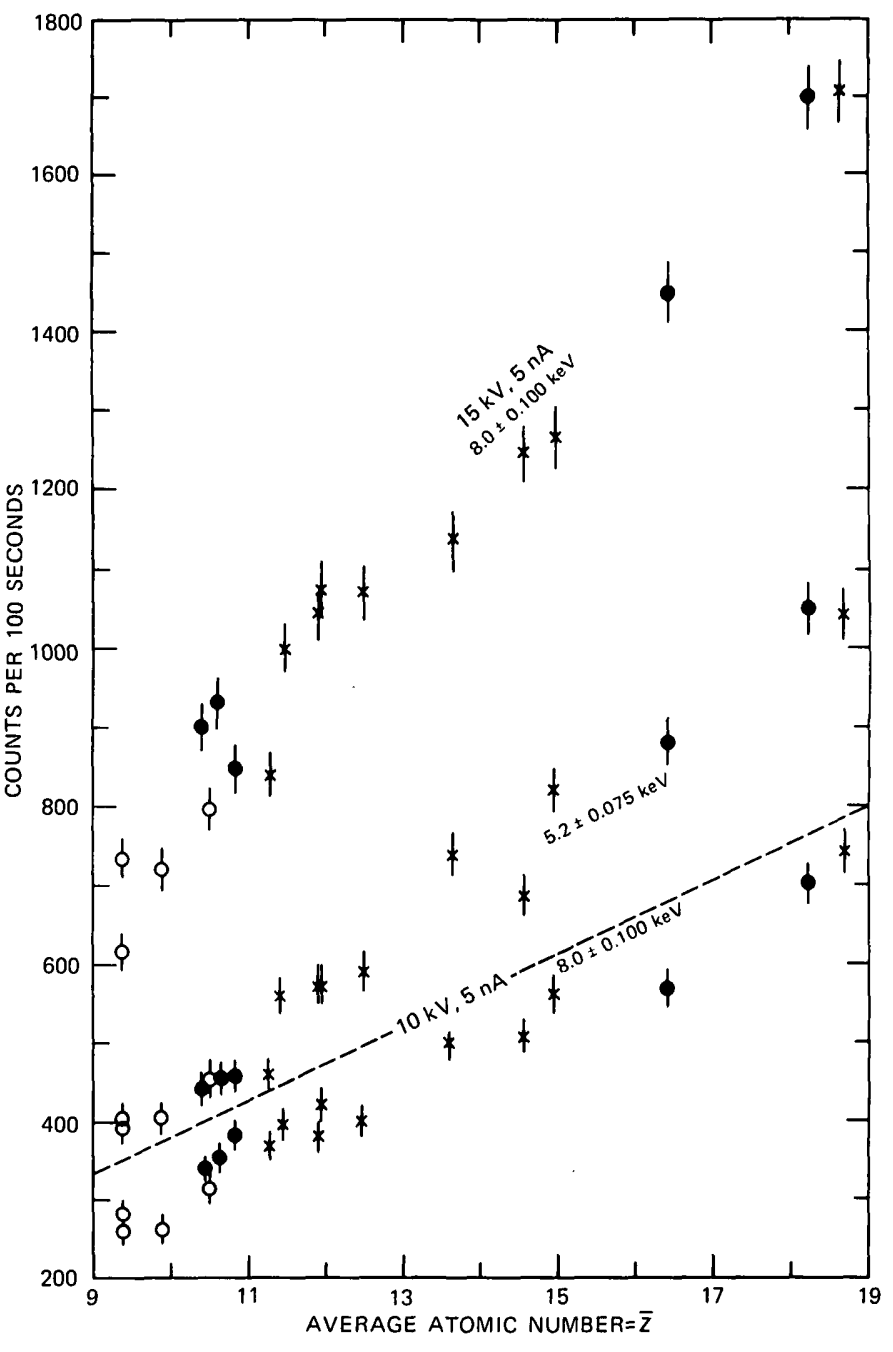

Figure 5.-Intensity data for spectral background in energy regions at $5.2 \pm 0.075 \mathrm{kcV}$ and $8.0 \pm 0.100 \mathrm{keV}$ for five simple oxides (solid dots), nine complex silicate minerals and glasses $(X)$, and four glasses fused 1:1 with lithium tetraborate (open circles).

$\mathrm{TiO}_{2}, \mathrm{Fe}$, and $\mathrm{Fe}_{2} \mathrm{O}_{3}$. We conducted a scries of 219 experiments with different conditions of operating voltage, 2 window widths for each element, and 7 to 8 different sample currents from 1 to $30 \mathrm{nA}$. Our results show that total spectral counting rates of 2,600 to $3,900 \mathrm{c} / \mathrm{s}$ (counts per second) are 
Table 3.-Characteristic peak counts and counting rates for $\mathrm{Cu}-25.62$ percent Au alloy at different microprobe operating conditions with and without pulsed optical feedback

[P, characterized peak counts; B, background counts; c/s, counts per second; P.O.F., pulsed optical feedback ]

\begin{tabular}{|c|c|c|c|c|c|c|c|c|c|c|}
\hline & \multicolumn{3}{|c|}{$\begin{array}{c}\mathrm{Cu} K \alpha \\
400 \mathrm{eV} \\
\text { window }\end{array}$} & \multicolumn{3}{|c|}{$\begin{array}{c}\mathrm{Au} L \alpha \\
400 \mathrm{eV} \\
\text { window }\end{array}$} & \multicolumn{3}{|c|}{$\begin{array}{c}\mathrm{Au} M \alpha \\
200 \mathrm{eV} \\
\text { window }\end{array}$} & \multirow{2}{*}{$\begin{array}{c}\text { Total } \\
\text { spectral } \\
\text { counts } \\
1.0-11.4 \mathrm{keV} \\
(\mathrm{c} / \mathrm{s})\end{array}$} \\
\hline & $\underset{(c / s)}{P}$ & $\begin{array}{l}\text { P.B } \\
(c / s)\end{array}$ & $\begin{array}{c}\mathrm{C} / \mathrm{s} \text { per } \\
\text { wt percent }\end{array}$ & $\begin{array}{c}P \\
(c / s)\end{array}$ & $\begin{array}{l}\text { P-B } \\
(\mathrm{c} / \mathrm{s})\end{array}$ & $\begin{array}{c}\mathrm{C} / \mathrm{s} \text { per } \\
\text { wt percent }\end{array}$ & $\begin{array}{c}P \\
(c / s)\end{array}$ & $\begin{array}{l}\text { P-B } \\
(c / s)\end{array}$ & $\begin{array}{c}\mathrm{C} / \mathrm{s} \text { per } \\
\text { wt percent }\end{array}$ & \\
\hline \multicolumn{11}{|c|}{$25 \mathrm{kV}, 2.45 \mathrm{nA}$ sample current ( $4.0 \mathrm{nA}$ beam current) } \\
\hline Without P.O.F. . & 541 & 497 & 6.68 & 31 & 16.5 & 0.644 & 1,300 & (') & $\left({ }^{1}\right)$ & $2,4,05$ \\
\hline With P.O.F. . . . & 763 & 723 & 9.72 & 78 & 56.4 & 2.20 & 190 & 107 & 4.2 & 2,666 \\
\hline \multicolumn{11}{|c|}{$20 \mathrm{kV}, 2.45 \mathrm{nA}$ sample current (4.0 nA beam current } \\
\hline Without P.O.F. . & 339 & 305 & 4.10 & 17 & 6.8 & 0.265 & 123 & 20.7 & 0.811 & 1,760 \\
\hline With P.O.F. . . . & 4.47 & 4.18 & 5.63 & 45 & 30 & 1.17 & 169 & 99 & 3.86 & 1,881 \\
\hline \multicolumn{11}{|c|}{$15 \mathrm{kV}, 3.55 \mathrm{nA}$ sample current ( $6.0 \mathrm{nA}$ beam current) } \\
\hline Without P.O.F. . & 204 & 172 & 2.31 & 10 & 2.4 & 0.093 & 143 & 4.1 & 1.60 & 554 \\
\hline With P.O.F. . ... & 295 & 270 & 3.63 & 25 & 11.0 & 0.430 & 207 & 127 & 4.98 & 1,760 \\
\hline
\end{tabular}

${ }^{1}$ Noise overload.

possible without significant dead-time losses. These dead-time losses occur at operating conditions of about $30 \mathrm{nA}$ sample current at $10 \mathrm{kV}$, and at $15 \mathrm{nA}$ sample current at $15 \mathrm{kV}$ for Si in $\mathrm{SiO}_{2}, \mathrm{Ti}$ in $\mathrm{TiO}_{2}, \mathrm{Fe}$ in $\mathrm{Fe}_{2} \mathrm{O}_{3}$, and $\mathrm{Cu}$ in metal for the system configuration described using the pulsed optical feedback modification. At operating voltages of $20 \mathrm{kV}$, serious dead-time losses occur above 5 to $10 \mathrm{nA}$ sample current.

The higher counting rate provided by pulsed optical feedback is demonstrated in table 3 by measurements on a $\mathrm{Cu}$-Au alloy at three operating conditions using the same EDS detector system with and without the pulsed optical system, respectively, for X-ray spectra of appreciably different energies measured simultaneously. Background values were determined using $\mathrm{Au}-\mathrm{Ag}$ alloys, pure $\mathrm{Cu}$, pure $\mathrm{Ag}$, and pure Au. These characteristic $\mathrm{X}$-ray counting rates are far superior to those cited by Beaman and Solosky (1972, p. 1602) for a $\mathrm{Cu}-20$ percent Au alloy using a 2,500-c/s total spectral counting rate. Table 3 indicates that the pulsed optical system improves spectral peak counting rates by a factor of 0.2 to 5.0 .

Woldseth (1972) advocated using pulse pileup rejection systems to correct for dead-time losses at high counting rates. Unless an online computer performs this correction in true live time, all the pulse pileup rejection systems extend the actual live-time counting period to correct for dead-time losses at high counting rates. This procedure is unacceptable to those of us who require simultaneous EDS and WDS analysis and therefore simultaneous counting termination using the electron-probe integrated-beam-current method.

\section{SUMMARY}

The energy dispersive spectrometer with single-channel pulse height analyzers may be used, in the absence of line interferences, as an ancillary detector for quantitative analysis of major elements in common minerals. Inasmuch as this detector provides added analytical capability to the electron microprobe, simultaneous energy dispersive and wavelength dispersive analysis is feasible. X-ray intensity count data for the energy dispersive system are handled in the same manner as count data obtained from the conventional wavelength dispersive spectrometers of the microprobe.

\section{REFERENCES CITED}

American Society for Testing and Materials, 1971, Energy dispersion $\mathrm{X}$-ray analysis-X-ray and electron probe analysis-A symposium: Am. Soc. Testing and Materials Spec. Tech. Pub. 485, 285 p.

Beaman, D. R., and Isasi, J. A., 1972, Electron beam microanalysis: Am. Soc. Testing and Materials Spec. Tech. Pub. 506, 80 p.

Beaman, D. R., and Solosky, L. F., 1972, Accuracy of quantitative electron probe microanalysis with energy dispersive spectrometers: Anal. Chemistry, v. 44, p. 1598-1610.

Bender, S. L., and Duff, R. H., 1971, Energy dispersion X-ray analysis with the transmission electron microscope, in Energy dispersion $\mathrm{X}$-ray analysis-X-ray and electron probe analysis: Am. Soc. Testing and Materials Spec. Tech. Pub. 485, p. 180-196.

Desborough, G. A., and Heidel, R. H., 1973, Characteristics, performance and quantitative analytical capability of an energy dispersive spectrometer on an electron microprobe using low operating voltages: Appl. Spectroscopy, v. 27, no. 6, p. 456-464.

Lifshin, Eric, 1971, Solid-state X-ray detectors for microprobe analysis, in Energy dispersion X-ray analysis-X-ray and electron probe analysis: Am. Soc. Testing and Materials Spec. Tech. Pub. 485, p. 140-153.

Myklebust, R. L., and Heinrich, K. F. J., 1971, Rapid quantitative electron probe microanalysis with a nondiffractive detector system, in Energy dispersion X-ray analysis-X-ray and electron probe analysis: Am. Soc. Testing and Materials Spec. Tech. Pub. 485, p. $232-242$.

Weast, R. C., ed., 1969, Handbook of chemistry and physics [50th ed.]: Cleveland, Ohio, Chemical Rubber Co., 2,074 p.

Woldseth, Rolf, 1972, X-ray energy spectroscopy: Am. Lab. v. 4, p. 79-86. 
Jour. Research U.S. Geol. Survey

Vol. 2, No. 4, July-Aug. 1974, p. 447-455

\title{
ACTIVITY-P.RODUCT CONSTANTS OF ARAGONITE AT $90^{\circ}$ AND $51^{\circ} \mathrm{C}$
}

\author{
By R. M. SIEBERT, ${ }^{1}$ P. B. HOSTETLER; ${ }^{12}$ and C. L. CHRIST; \\ Columbia, Mo.; Menlo Park, Calif.
}

\begin{abstract}
The ... activity-product constants of aragonite, $K_{\mathrm{A}}=\left[\mathrm{Ca}^{2+}\right]\left[\mathrm{CO}_{3}{ }^{2-}\right]$ (where the brackets denote activities), were determined experimentally at $90^{\circ} \mathrm{C}$ and at $51^{\circ} \mathrm{C}$. Results at $90^{\circ} \mathrm{C}$ were obtained from four separate dolomite dissolution runs, in which aragonite precipitated and came to equilibrium with the aqueous phase (from the direction of. supersaturation), and from two runs starting with aragonite suspended in dilute $\mathrm{MgCl}_{2}$ solutions (from the direction of undersaturation). The average values of $K_{A}$ from the six runs were in excellent agreement; for the negative logarithm of $K_{\mathrm{A}}, \mathrm{p} K_{\mathrm{A}}$, they yield a value of $8.95 \pm 0.05$. One run was made at $51^{\circ} \mathrm{C}$ starting with aragonite suspended in dilute $\mathrm{MgCl}_{2}$ solution; the value of $\mathrm{pK}$ at $51^{\circ} \mathrm{C}$ is $8.61 \pm 0.05$. No X-ray detectable calcite was found at the conclusion of any of the runs; including a dolomite dissolution run at $90^{\circ} \mathrm{C}$ (D-10) that was sampled over a period of $1.0,268 \mathrm{~h}$ and toward the end had a concentration of approximately 0.002 molal total dissolved magnesium.
\end{abstract}

Arigonite should, from stable-phase equilibria considerations, be a very rare mineral, but it is not. Aragonite, rather than calcite, forms and persists in a variety of low and earth-surface temperature environments. There is a large and growing literature concerned with the geologic occurrences of aragonite, and with the reasons for its persistence. Recent reviews of these subjects include those of Berner (1971); Taft (1967), Katz, Sass, Starinsky, and Holland (1972), Katz (1973), Folk (1973), and Lippmann (1973); these references may be consulted for details.

It seems clear that aragonite (derived principally from organisms) can persist in seawater for millions of years (Berner, 1971). Appropriate to somewhat higher temperatures, aragonite is found as crystals, pisolites, or in the sinter from hot spring and geyser deposits (Palache and others, 1951). Occasionally, it is found associated with zeolites in vesicular basalts (Neuerberg, 1951). In the very high pressure, relatively low temperature environment of the blueschist metamorphic facies (Coleman and Lee, 1962), aragonite apparently forms in its own field of stability. Because aragonite is a geologically important mineral, its aqueous solubility over a range of temperatures and pressures is of considerable interest. This

\footnotetext{
${ }^{1}$ Department of Geology, University of Missouri.

${ }^{2}$ Present address: School of Earth Sciences, Macquarie University, North Rydc, N.S.W. 2113; Australia.
}

paper does not evaluate published data on the solubility of aragonite; Langmuir (1964) has done this and promised an additional evaluation of the stability of the mineral (Langmuir, 1968). Rather, we present new experimental data on aragonite stability based on long-term solubility measurements at $51^{\circ}$ and $90^{\circ} \mathrm{C}$ and at 1 atm total pressure.

Our experimental studies did not begin as a deliberate investigation of aragonite stability. In the course of studies of the dissolution of dolomite in pure water saturated with $\mathrm{CO}_{2}$ at $90^{\circ} \mathrm{C}$ and at $1 \mathrm{~atm}$ total pressure, we found that for many of the runs, aragonite began to precipitate after 2 to 10 weeks. The runs were frequently sampled, and $\mathrm{pH}$ and concentrations of dissolved constituents were determined. It was evident that that values of the ion product, $\left[\mathrm{Ca}^{2+}\right]\left[\mathrm{CO}_{3}^{2-}\right]$ (where the bracketed species are the activities of the uncomplexed ions), were consistent as a run progressed, and it could be assumed that the solution was in equilibrium with aragonite. To check this assumption, the solubility of aragonite was measured, starting with aragonite suspended in $0.0025 \dot{m} \mathrm{MgCl}_{2}$ solutions. Two separate runs at $90^{\circ} \mathrm{C}$ gave $\left[\mathrm{Ca}^{2+}\right]\left[\mathrm{CO}_{3}^{2-}\right]$ values in excellent agreement with those obtained from dolomite dissolution. Thus, the stability of aragonite was determined at $90^{\circ} \mathrm{C}$ from both the direction of supersaturation and that of undersaturation. In addition, one run was made at $51^{\circ} \mathrm{C}$, starting with aragonite suspended in $0.0025 \mathrm{~m} \mathrm{MgCl} 2$. The results of the dolomite runs as they apply to dolomite stability will be reported elsewhere.

A number of studies have been made on the rate and mechanisms of the conversion of aragonite to the more stable calcite. These studies are described in detail in the review articles quoted in the foregoing. Here, we only wish to consider briefly the role of $\mathrm{Mg}^{2+}$ in inhibiting the aragoniteto-calcite transformation. Bischoff and Fyfe (1968) investigated the rate of conversion of aragonite to calcite at $108^{\circ} \mathrm{C}$ in aqueous solutions containing $0.001 \mathrm{~m} \mathrm{CaCl}_{2}$ and $0 \mathrm{~m}, 10^{-4} \mathrm{~m}$, $1.5 \times 10^{-4} \mathrm{~m}$, and $2 \times 10^{-4} \mathrm{~m} \mathrm{MgCl}_{2}$; conversion began essentially immediately, at $13 \mathrm{~h}$, at $35 \mathrm{~h}$, and at $52 \mathrm{~h}$, respectively. Our results cannot be compared directly with these, owing to differences in temperature $\left(90^{\circ}\right.$ versus $\left.108^{\circ} \mathrm{C}\right)$ and in concentration of $\mathrm{Mg}^{2+}$ (approximately $2 \times 10^{-3} \mathrm{~m}$ in our solutions versus $2 \times 10^{-4} \mathrm{~m}$ in theirs at the highest concentra- 
tion of $\left.\mathrm{Mg}^{2+}\right)$. However, if we consider that the reaction rate of conversion doubles for every $10^{\circ}$ rise in temperature, then at $90^{\circ} \mathrm{C}$, and for $2 \times 10^{-4} \mathrm{~m} \mathrm{MgCl}_{2}$, the conversion should begin at approximately $208 \mathrm{~h}$. At the end of our longest runs, D-10 $(10,268 \mathrm{~h})$ and A-1 $(5,568 \mathrm{~h})$, no calcite was detected (by X-ray diffraction). The not-surprising conclusion is that the time required for the aragonite-to-calcite conversion to commence increases rapidly with increase in concentration of dissolved magnesium.

\section{PROCEDURE AND EXPERIMENTAL RESULTS}

\section{Description of samples and experimental method}

Four long-term dolomite aqueous dissolution runs at $90^{\circ} \mathrm{C}$ produced aragonite in apparent equilibrium with the aqueous phase. In addition, two solubility runs at $90^{\circ} \mathrm{C}$ and one at $51^{\circ} \mathrm{C}$ were made starting with aragonite suspended in 0.0025 $m \mathrm{MgCl}_{2}$ solutions. Three of the dolomite runs (D-3, D-4, and D-10) were made using a coarse-grained dolomite marble from Thornwood, N.Y. In the fourth run (D-5), saddle-shaped crystals from Picher, Okla., were used. The composition of the Thorn wood, N.Y., dolomite is $\left(\mathrm{Ca}_{1.03} \mathrm{Mg}_{0.9} \mathrm{Fe}_{0.005}\right)\left(\mathrm{CO}_{3}\right)_{2}$ and that of the Picher, Okla., dolomite is $\left(\mathrm{Ca}_{1.08} \mathrm{Mg}_{0.89} \mathrm{Fe}_{0.03}\right)\left(\mathrm{CO}_{3}\right)_{2}$ (R. M. Siebert, analyst). For those solubility runs starting with aragonite, the aragonite used came from Tolina Springs, Calif., and consisted of an aggregate of coarse-grained, clear, columnar crystals 1 to $3 \mathrm{~mm}$ across and up to $1 \mathrm{~cm}$ long. The composition of this aragonite is essentially $\mathrm{Ca}_{0.9} \mathrm{Sr}_{0.03} \mathrm{CO}_{3}$; in addition, this sample contains 0.03 weight percent $\mathrm{Fe}$, corresponding to 0.0005 moles of $\mathrm{Fe}$ per mole of aragonite (R. M. Siebert, analyst). Samples were prepared by hand-grinding portions of the materials in a diamonite mortar and screening them into one 200- to 325-mesh-size fraction and one smaller than 325. Depending on the desired run conditions, the ground samples were either untreated or washed with concentrated $\mathrm{HCl}$ until vigorous effervescence ceased. This acid wash served to remove the more readily soluble fine-grained and disordered material. The dolomite samples yielded clean, sharp-lined X-ray diffraction patterns, characteristic of ordered dolomite; these patterns gave no indication of the presence of any other phase. Similarly, patterns of the aragonite samples indicated that only well-crystallized aragonite was present.

All the solubility determinations were carried out in temperature-controlled polypropylene water baths, previously described in detail by Hostetler and Christ (1968). The solid material of a run was suspended in distilled and de-ionized water (dolomite runs), or in $0.0025 m \mathrm{MgCl}_{2}$ solution (aragonite runs). The $\mathrm{MgCl}_{2}$ solution was used to prevent the aragonite from converting to calcite. The suspensions were made in polypropylene reaction vessels and stirred with Teflon-coated magnetic bars. In runs D-3, D-4, and D-5, the stirring bars rested on the bottoms of the reaction vessels and undoubtedly produced some grinding of the solids at the bottoms. For run D-10, and the aragonite runs, the stirring bars were suspended 1 in. above the bottoms of the vessels by thin Nichrome wires attached to ball-bearing fishing swivels to permit rotation of the bars. It was hoped, in this way, to minimize grinding of the solids. Pure $\mathrm{CO}_{2}$ gas, presaturated with water vapor at the temperature of the run, was bubbled through the suspensions for the duration of the runs. Temperatures were maintained constant to within approximately $\pm 0.3^{\circ}$ prior to sampling, and just before sampling the temperature was read to the nearest $0.1^{\circ}$. In subsequent calculations the precise temperature was taken into account. The specific conditions of the runs were as follows:

D-3. Thornwood, N.Y., dolomite; $6.0 \mathrm{~g}$ of acid-washed, 200- to 325 -mesh material in $1,800 \mathrm{ml}$ of water at $90^{\circ} \mathrm{C}$. Nominal $P_{\mathrm{CO}_{2}}=0.29 \mathrm{~atm}$. Run lasted $2,232 \mathrm{~h}$.

D-4. Thornwood, N.Y., dolomite; $5.0 \mathrm{~g}$ of untreated, smaller than 325 -mesh material in $1,800 \mathrm{ml}$ of water at $90^{\circ} \mathrm{C}$. Nominal $P_{\mathrm{CO}_{2}}=0.29 \mathrm{~atm}$. Run lasted $2,232 \mathrm{~h}$.

D.5. Picher, Okla., dolomite; $6.0 \mathrm{~g}$ of untreated, smaller than 200 -mesh material in $1,800 \mathrm{ml}$ of water at $90^{\circ} \mathrm{C}$. Nominal ${ }^{P} \mathrm{CO}_{2}=0.29 \mathrm{~atm}$. Run lasted $2,232 \mathrm{~h}$.

D-10. Thornwood, N.Y., dolomite; $10 \mathrm{~g}$ of acid-washed smailer than 325 -mesh material in $1,800 \mathrm{ml}$ of water at $90^{\circ} \mathrm{C}$. Nominal $\mathrm{PCO}_{2}=0.29 \mathrm{~atm}$. Run lasted $10,268 \mathrm{~h}$.

A-1. Tolina Springs, Calif., aragonite; $10 \mathrm{~g}$ of acid-washed 200- to 325 -mesh material in $1,800 \mathrm{ml}$ of $0.0025 \mathrm{~m} \mathrm{MgCl}_{2}$ solution at $90^{\circ} \mathrm{C}$. Nominal $P_{\mathrm{CO}_{2}}=0.29 \mathrm{~atm}$. Run lasted $5,568 \mathrm{~h}$.

A-2. Tolina Springs, Calif., aragonite; $5.0 \mathrm{~g}$ of acid-washed less than 325 -mesh material in $1,800 \mathrm{ml}$ of $0.0025 \mathrm{~m} \mathrm{MgCl}_{2}$ solution at $90^{\circ} \mathrm{C}$. Nominal $P_{\mathrm{CO}_{2}}=0.29 \mathrm{~atm}$. Run lasted $530 \mathrm{~h}$.

2-A-1. After $5,568 \mathrm{~h}$ the temperature of the A-1 run was lowered from $90^{\circ}$ to $51^{\circ} \mathrm{C}$, and the ensuing 2-A-1 run continued for an additional $2,518 \mathrm{~h}$. Nominal $P_{\mathrm{CO}_{2}}=0.86 \mathrm{~atm}$.

The values for the nominal $\mathrm{CO}_{2}$ pressures, $P_{\mathrm{CO}_{2}}$, given in the foregoing were calculated from measured barometric pressures and from the values of the vapor pressure of water as a function of temperature given by Weast (1967, p. D-110).

The $\mathrm{pH}$ of the runs was monitored at temperature using a Beckman Research model pH meter (Catalog No. 101900) and a Leeds and Northrup Speedomax Type G Recorder, in conjunction with a custom-built combination electrode fabricated by Beckman Instruments. ${ }^{1}$ This electrode has a large (7 $\mathrm{mm}) \mathrm{pH}$-sensitive glass bulb and a continuous-ring ceramic frit junction. The electrode was maintained in contact with the solution only during the duration of a $\mathrm{pH}$ measurement. Immediately after a $\mathrm{pH}$ measurement, $25 \mathrm{ml}$ of a suspension was withdrawn, filtered through a $0.45 \mu$ Millipore filter, and the filtrate slightly acidified to prevent carbonate precipitation. Later the filtrate was analyzed for aqueous calcium and magnesium using a Perkin-Elmer Model 290 atomic absorption instrument. After filtering, the solid material was returned to

'Use of trade names is for descriptive purposes only and does not constitute an endorsement of the products by the U.S. Geological Survey. 
the appropriate reaction vessel, and for the dolomite runs, sufficient water was added to bring the liquid volume back to the original value. Volume level was also maintained between samplings for all the runs. After sampling, for the aragonite run $\mathrm{A}-2,25 \mathrm{ml}$ of $0.0025 \mathrm{~m} \mathrm{MgCl}_{2}$ solution, plus the amount of water necessary to maintain constant volume, was added. This procedure was also followed during most of the duration of the A-1 run. During the latter stages of the A-1 run, and for all the 2-A-1 run, only pure water was added. However, because constant volume was maintained, it is possible to calculate the concentration of dissolved magnesium at each sampling for all the runs. The large ratio of total volume of suspension to mass of solid, employed in these runs, ensured that any practical departures from constant volume would not result in significant errors in the solubility results.

At the termination of the dolomite runs D-3, D-4, and D-10, the suspensions were allowed to stand for approximately 20 min, whereupon the bulk of the solids settled to the bottoms of the reaction vessels. For each run, the upper 90 percent of the supernatant liquid, containing a relatively small amount of solids still in suspension, was filtered through a $0.45 \mu$ Millipore filter, the filtrate retained for chemical analysis, and the solids preserved as sample S-1. The remaining, thicker, bottom liquid-solids mixture was then filtered, and the solids were retained as sample S-2. Finally, solid material was scraped from the sides of the reaction vessel and designated sample $\mathrm{S}$-3. X-ray diffraction analysis showed that relative to dolomite there was abundant aragonite in S-1, a moderate amount in $\mathrm{S}-3$, and little or none in S-2. Otherwise the X-ray diffractometer patterns of the samples did not differ significantly from those of the starting materials. The aragonite run 2-A-1 was terminated in the same way, except that the solid material was not divided into several samples. The X-ray diffractometer pattern of the aragonite at the end of the run was the same as that of the starting material.

The filtrates were analyzed for dissolved iron, silica, and potassium, and, for the 2-A-1 run, also for dissolved strontium. Iron was not detectable in any of the runs $(\mathrm{Fe}<0.1 \mathrm{p} / \mathrm{m})$. For run $\mathrm{D}-3$, dissolved silica was $0.85 \mathrm{p} / \mathrm{m}$, and potassium $5.0 \mathrm{p} / \mathrm{m}$; for D-4, silica was $1.4 \mathrm{p} / \mathrm{m}$, and potassium $4.5 \mathrm{p} / \mathrm{m}$; for D-10, silica was $0.60 \mathrm{p} / \mathrm{m}$, and potassium $5.0 \mathrm{p} / \mathrm{m}$. For the run $2-A-1$, dissolved silica was $0.57 \mathrm{p} / \mathrm{m}$, potassium $0.1 \mathrm{p} / \mathrm{m}$, and strontium $6.2 \mathrm{p} / \mathrm{m}$.

\section{Solubility data}

The experimental solubility data for total dissolved calcium, $\mathrm{Ca}^{2+}(\mathrm{t})$, total dissolved magnesium $\mathrm{Mg}^{2+}(\mathrm{t})$, and $\mathrm{pH}$ values, as a function of time, are given in table 1 for the dolomite dissolution runs, and in table 2 for the aragonite solubility runs. Much more data than are listed in table 1 were obtained in the dolomite runs; these will be reported elsewhere. The data that are listed are those appropriate to the calculation of the activity-product constani of aragonite.
Table 1.-Solubility data for aragonite from dissolution of dolomite

\begin{tabular}{cccccc}
\hline Sample & Time & $\mathrm{pH}$ & $\mathrm{Ca}^{2+}(\mathrm{t})$ & $\mathrm{Mg}^{2+}(\mathrm{t})$ & $\frac{m \mathrm{Ca}^{2+}(\mathrm{t})}{\left(m \times 10^{5}\right)}$ \\
$\left(m \times 10^{5}\right)$ & $\frac{m \mathrm{Mg}^{2+}(\mathrm{t})}{}$
\end{tabular}

\begin{tabular}{lllllr}
\hline \multicolumn{5}{c}{ Sample D-31 } \\
\hline 16 & 1510 & 6.55 & 176 & 167 & 1.05 \\
17 & 1658 & 6.59 & 128 & 177 & .72 \\
18 & 1784 & 6.55 & 132 & 180 & .73 \\
19 & 1924 & 6.58 & 130 & 191 & .68 \\
20 & 21.21 & 6.58 & 125 & 192 & .65 \\
21 & 2232 & 6.65 & 122 & 212 & .58 \\
\hline \multicolumn{7}{c}{ Sample D.4. } \\
\hline \multicolumn{7}{c}{}
\end{tabular}

\begin{tabular}{|c|c|c|c|c|}
\hline $\begin{array}{l}13 \\
14 \\
15 \\
16 \\
17 \\
18 \\
19 \\
20 \\
21\end{array}$ & 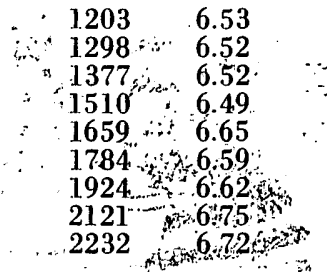 & $\begin{array}{r}161 \\
143 \\
154 \\
175 \\
11.1 \\
92 \\
103 \\
67 \\
679\end{array}$ & $\begin{array}{l}157 \\
167 \\
1.94 \\
200 \\
217 \\
245 \\
267 \\
303 \\
315\end{array}$ & $\begin{array}{r}1.03 \\
.86 \\
.79 \\
.88 \\
.51\end{array}$ \\
\hline & Samp & $D=5^{2}$ & & \\
\hline
\end{tabular}

\begin{tabular}{lllllr}
\hline 16 & 1510 & 6.53 & 197 & 159 & 1.24 \\
17 & 1659 & 6.57 & 143 & 163 & .88 \\
18 & 1784 & 6.52 & 132 & 163 & .81 \\
19 & 1924 & 6.59 & 142 & 196 & .72 \\
20 & 2121 & 6.64 & 112 & 237 & .47 \\
21 & 2232 & 6.65 & 108 & 263 & .41 \\
\hline
\end{tabular}

\begin{tabular}{rrrrrr}
\hline \multicolumn{5}{c}{ Sample D-10 } \\
\hline 1 & 138 & 6.61 & 141 & 133 & 1.06 \\
2 & 287 & 6.67 & 133 & 200 & .66 \\
3 & 356 & 6.69 & 119 & 219 & .54 \\
4 & 435 & 6.68 & 111 & 243 & .46 \\
5 & 494 & 6.69 & 99 & 255 & .39 \\
6 & 568 & 6.71 & 97 & 267 & .36 \\
7 & 640 & 6.71 & 92 & 262 & .35 \\
8 & 714 & 6.70 & 90 & 260 & .35 \\
9 & 812 & 6.72 & 92 & 262 & .35 \\
10 & 883 & 6.71 & 89 & 262 & .34 \\
11 & 954 & 6.74 & 87 & 265 & .33 \\
12 & 1026 & 6.73 & 87 & 234 & .37 \\
13 & 1097 & 6.72 & 88 & 232 & .38 \\
14 & 1168 & 6.69 & 87 & 234 & .37 \\
15 & 2060 & 6.64 & 96 & 226 & .42 \\
16 & 2349 & 6.71 & 91 & 259 & .35 \\
17 & 3092 & 6.69 & 95 & 241 & .39 \\
18 & 3356 & 6.66 & 76 & 247 & .31 \\
19 & 4195 & 6.64 & 94 & 218 & .43 \\
20 & 4411 & 6.63 & 100 & 226 & .44 \\
21 & 5031 & 6.73 & 112 & 226 & .50 \\
22 & 5706 & 6.68 & 105 & 255 & .41 \\
23 & 6256 & 6.71 & 103 & 237 & .44 \\
24 & 6427 & 6.76 & 88 & 280 & .31 \\
25 & 6764 & 6.73 & 62 & 294 & .21 \\
26 & 7532 & 6.76 & 77 & 267 & .29 \\
27 & 7891 & 6.69 & 77 & 239 & .32 \\
28 & 8397 & 6.72 & 84 & 206 & .41 \\
29 & 9643 & 6.70 & 75 & 185 & .41 \\
30 & 10268 & 6.71 & 75 & 197 & .38 \\
\hline
\end{tabular}

${ }^{1}$ Dolomite from Thornwood, N.Y. Temperature $90^{\circ} \mathrm{C}$. See text for description of preparation of samples.

${ }^{2}$ Dolomite from Picher, Okla. Temperature $90^{\circ} \mathrm{C}$. See text for description of preparation of sample.

Approximate errors of analyses: $\mathrm{Ca}$ and $\mathrm{Mg} \pm 3$ percent; $\mathrm{pH}$ reproducible to $\pm 0.04 \mathrm{pH}$ units. 
Table 2.-Solubility data for aragonite in dilute $\mathrm{MgCl}_{2}$ solutions

\begin{tabular}{|c|c|c|c|c|}
\hline Sample & $\begin{array}{l}\text { Time } \\
\text { (h) }\end{array}$ & pH & $\begin{array}{c}\mathrm{Ca}^{2+}(\mathrm{t}) \\
\left(m \times 10^{5}\right)\end{array}$ & $\begin{array}{c}\mathrm{Mg}^{2+}(t) \\
\left(m \times 10^{5}\right)\end{array}$ \\
\hline \multicolumn{5}{|c|}{ Sample A-1 ${ }^{2}$} \\
\hline $\begin{array}{r}1 \\
2 \\
3 \\
4 \\
5 \\
6 \\
7 \\
8 \\
9 \\
10 \\
11 \\
12 \\
13 \\
14 \\
15 \\
16\end{array}$ & $\begin{array}{r}11 \\
28 \\
74 \\
172 \\
219 \\
272 \\
314 \\
368 \\
457 \\
530 \\
2454 \\
2694 \\
3553 \\
3769 \\
\mathbf{4 4 4 4} \\
\mathbf{5 5 6 8}\end{array}$ & $\begin{array}{l}6.49 \\
6.51 \\
6.50 \\
6.55 \\
6.54 \\
6.52 \\
6.51 \\
6.53 \\
6.49 \\
6.50 \\
6.52 \\
6.45 \\
6.50 \\
6.51 \\
6.57 \\
6.46\end{array}$ & $\begin{array}{l}254 \\
259 \\
249 \\
222 \\
232 \\
237 \\
237 \\
230 \\
227 \\
227 \\
235 \\
218 \\
243 \\
250 \\
234 \\
238\end{array}$ & $\begin{array}{l}250 \\
250 \\
250 \\
250 \\
250 \\
250 \\
250 \\
250 \\
250 \\
250 \\
247 \\
243 \\
236 \\
233 \\
229 \\
222\end{array}$ \\
\hline \multicolumn{5}{|c|}{ Sample A-2 ${ }^{1}$} \\
\hline $\begin{array}{r}1 \\
2 \\
3 \\
4 \\
5 \\
5 \\
-6 \\
7 \\
8 \\
9 \\
10\end{array}$ & $\begin{array}{r}12 \\
28 \\
75 \\
172 \\
220 \\
273 \\
315 \\
368 \\
458 \\
530\end{array}$ & $\begin{array}{l}6.50 \\
6.51 \\
6.51 \\
6.53 \\
6.55 \\
6.55 \\
6.54 \\
6.54 \\
6.49 \\
6.49\end{array}$ & $\begin{array}{l}230 \\
242 \\
228 \\
225 \\
222 \\
243 \\
233 \\
232 \\
225 \\
219\end{array}$ & $\begin{array}{l}250 \\
250 \\
250 \\
250 \\
250 \\
250 \\
250 \\
250 \\
250 \\
250\end{array}$ \\
\hline \multicolumn{5}{|c|}{ Sa mple $2-\mathbf{A}-1^{2}$} \\
\hline $\begin{array}{r}1 \\
2 \\
3 \\
4 \\
5 \\
6 \\
7 \\
8 \\
9 \\
10\end{array}$ & $\begin{array}{r}357 \\
502 \\
694 \\
1079 \\
1532 \\
1775 \\
2015 \\
2110 \\
2374 \\
2518\end{array}$ & $\begin{array}{l}6.08 \\
6.10 \\
6.08 \\
6.10 \\
6.08 \\
6.07 \\
6.04 \\
6.06 \\
6.04 \\
6.04\end{array}$ & $\begin{array}{l}676 \\
686 \\
676 \\
618 \\
605 \\
599 \\
593 \\
593 \\
624 \\
624\end{array}$ & $\begin{array}{l}222 \\
219 \\
216 \\
210 \\
207 \\
204 \\
201 \\
198 \\
194 \\
191\end{array}$ \\
\hline
\end{tabular}

${ }^{1}$ Aragonite from Tolina Springs, Calif. Temperature $90^{\circ} \mathrm{C}$. See text for description of preparation of samples.

${ }^{2}$ Aragonite from Tolina Springs; Calif. Temperature $51^{\circ} \mathrm{C}$. See text for description of preparation of sample.

See footnotes of table 1 for analytical errors.

The ratio of calcium to magnesium was the criterion for deciding when aragonite was forming: when it fell significantly below unity, aragonite was being formed. For example, for run D-3 (table 1), samples 1 to 16 all have calcium-magnesium ratios greater than unity. For sample 16 , at $1510 \mathrm{~h}$, the ratio is 1.05 ; for sample 17 , at $1658 \mathrm{~h}$, the ratio is 0.72 . Thus, the data for samples 17 to 21 are considered appropriate to the calculation of the activity-product constant of aragonite; similar considerations apply to the other dolomite runs. The calcium-magnesium ratios, at first, decrease with increasing time and then seem to approach some constant average value.
This approach to constancy, shown best by the results for the very long-term run D-10 (table 1), is probably indicative of an approach to some sort of steady-state condition for the entire system: dolomite-aragonite-aqueous phase. However, as indicated in the foregoing, we wish to defer detailed discussion of the overall dolomite dissolution results and their interpretation.

\section{ACTIVITY-PRODUCT CONSTANTS}

\section{Preliminary considerations}

In the following, a simplified notation is used frequently. The terms $\mathrm{pH}, \mathrm{pCa}, \mathrm{pMg}$, and $\mathrm{pCO}_{3}$ represent $-\log [i]$, where [i] represents activities of $\mathrm{H}^{+}, \mathrm{Ca}^{2+}, \mathrm{Mg}^{2+}$, and $\mathrm{CO}_{3}^{2-}$, respectively. The term $\mathrm{p} K$ represents the negative logarithm of any equilibrium constant, $K$, of interest. Ion products are designated by $K^{\prime}$. The following ion products will be considered: $\left[\mathrm{Ca}^{2+}\right]\left[\mathrm{CO}_{3}^{2-}\right]=K_{\mathrm{A}}^{\prime}$ (for aragonite), $\left[\mathrm{Mg}^{2+}\right]\left[\mathrm{CO}_{3}^{2-}\right]=K_{\mathrm{M}}^{\prime}$ (for magnesite), and $\left[\mathrm{Ca}^{2+}\right]\left[\mathrm{Mg}^{2+}\right]\left[\mathrm{CO}_{3}^{2-}\right]^{2}=K_{\mathrm{D}}^{\prime}$ (for dolomite).

Activity-product constants of aragonite, at the two temperatures $90^{\circ}$ and $51^{\circ} \mathrm{C}$, were calculated from the solubility and $\mathrm{pH}$ data listed in tables 1 and 2 . The expression for the activity-product constant is

$$
\left[\mathrm{Ca}^{2+}\right]\left[\mathrm{CO}_{3}^{2-}\right]=K_{\mathrm{A}}
$$

In making the calculations, the presence of the ion pairs $\mathrm{CaHCO}_{3}^{+}$and $\mathrm{MgHCO}_{3}^{+}$in the aqueous phase was taken into account.

Some other possible ion pairs in solutions are $\mathrm{CaOH}^{+}$, $\mathrm{MgOH}^{+}, \mathrm{CaCO}_{3}^{\circ}$, and $\mathrm{MgCO}_{3}^{\circ}$. The dissociation constant of $\mathrm{MgOH}^{+}$given by

$$
\left[\mathrm{Mg}^{2+}\right]\left[\mathrm{OH}^{-}\right] /\left[\mathrm{MgOH}^{+}\right]=K_{\mathrm{MgOH}^{+}}
$$

has recently been determined over the temperature range $10^{\circ}$ to $90^{\circ} \mathrm{C}$ by $\mathrm{McGee}$ and Hostetler (1974). They found the value of $\mathrm{pK} \mathrm{MgOH}^{+}$at $90^{\circ} \mathrm{C}$ to be $2.54 \pm 0.09$, and at $51^{\circ} \mathrm{C}$ to be $2.37 \pm 0.03$. For the solutions studied in the present investigation the values of $\left[\mathrm{Mg}^{2+}\right]$ and $\mathrm{pH}$ are such that the concentrations of $\mathrm{MgOH}^{+}$are too small to be significant in calculating $\mathrm{p} K_{\mathrm{A}}$. Sillén and Martell (1964, p. 42) list the values of $\mathrm{p} K \mathrm{CaOH}^{+}$obtained by a number of investigators, including values from $0^{\circ}$ to $40^{\circ} \mathrm{C}$. It is clear from these values that $\mathrm{CaOH}^{+}$is less stable than $\mathrm{MgOH}^{+}$at all comparable temperatures. It follows that $\mathrm{CaOH}^{+}$can be neglected. Jacobson and Langmuir (1974) list results for the $\mathrm{p} K$ values of $\mathrm{CaCO}_{3}^{\circ}$ and $\mathrm{MgCO}_{3}^{\circ}$ obtained by E. J. Reardon and others (in Jacobson and Langmuir, 1974). These investigators found for the temperature range $0^{\circ}$ to $50^{\circ} \mathrm{C}$ that

$$
\mathrm{p} K_{\mathrm{CaCO}_{3}^{\circ}}=0.22+0.0100 T
$$

and

where $T$ is in $\mathrm{K}$.

$$
\mathrm{p} K_{\mathrm{MgCO}_{3}^{\circ}}=-0.82+0.0100 T
$$


Assuming that these linear relationships hold to $90^{\circ} \mathrm{C}$, then Final values of $\left[\mathrm{Ca}^{2+}\right]$ and $\left[\mathrm{HCO}_{3}^{-}\right]$(from which $\left[\mathrm{CO}_{3}^{2-}\right]$ values $\mathrm{p} K_{\mathrm{CaCO}_{3}^{\circ}}$ is 3.46 at $51^{\circ} \mathrm{C}$, and 3.85 at $90^{\circ} \mathrm{C} ; \mathrm{p} K_{\mathrm{MgCO}_{3}^{\circ}}$ is 2.42 were determined) were computer calculated by iteration to and 2.81, at the respective temperatures. Although these ion pairs are more stable than the ion pairs listed in the foregoing, they may still be neglected in the calculation of $\mathrm{p} K_{\mathrm{A}}$ for the solutions studied in the present investigation, because of the high ratio of dissolved $\mathrm{HCO}_{3}^{-}$to $\mathrm{CO}_{3}^{2-}$ present.

P. B. Hostetler and others (unpub. data, 1973) have determined the $\mathrm{p} K$ values of $\mathrm{CaHCO}_{3}^{+}$over the temperature range $10^{\circ}$ to $90^{\circ} \mathrm{C}$. The values that they determined for temperatures of $90^{\circ} \mathrm{C}(1.50)$ and $51^{\circ} \mathrm{C}(1.29)$ are used in the ensuing calculations. These were also used for the $\mathrm{p} K$ of $\mathrm{MgHCO}_{3}^{+}$. Two points should be noted here:

1. It is not necessary to know accurately the $\mathrm{pK}$ of $\mathrm{MgHCO}_{3}^{+}$, because $\mathrm{MgHCO}_{3}^{+}$plays a role only in the calculation of the ionic strength of a solution.

2. The calculated value of $\mathrm{p} K_{\mathrm{A}}$ varies slowly with variation of $\mathrm{p} K$ of $\mathrm{CaHCO}_{3}^{+}$near 1.5 . If the 1.50 value is changed by \pm 0.1 , then $\mathrm{p} K_{A}$ changes by only \pm 0.01 , a value well within the limits of error of the present experimental work.

Two methods were used to calculate values of $\mathrm{p} K_{\mathrm{A}}$ from the experimental data. These methods are described in the following sections and are designated as the $\mathrm{pH}$-charge balance method and the $\mathrm{pH} \cdot \mathrm{P}_{\mathrm{CO}_{2}}$ method.

\section{$\mathrm{pH}$-charge balance method for calculating $\mathrm{p} K_{\mathrm{A}}$}

A value of $\mathrm{p} K_{\mathrm{A}}$ was calculated for each sample from the data listed in tables 1 and 2 . Values of activity coefficients, $\gamma_{i}$, were calculated using the Debye-Hückel equation (Garrels and Christ, 1965, p. 61.)

$$
-\log \gamma_{\mathrm{i}}=\left(A \mathrm{z}_{i}^{2} I^{1 / 2}\right) /\left(1+\stackrel{\circ}{a_{i}} B I^{1 / 2}\right) .
$$

Values of $A$ and $B$ were taken from Helgeson (1.967); $I$ is ionic strength in molal units. The values of å $\times 10^{8}$ used were 5.5 for $\mathrm{Ca}^{2+}$ (Christ and others, 1974), 6.5 for $\mathrm{Mg}^{2+}$ (Hostetler, 1963), and 5.5 for $\mathrm{HCO}_{3}^{-}$(Christ and Hostetler, 1970). It was assumed that the $\gamma$-values for $\mathrm{MgHCO}_{3}^{+}$and $\mathrm{CaHCO}_{3}^{+}$are the same as those for $\mathrm{HCO}_{3}^{-}$. Any errors resulting from this assumption are insignificant in the calculation of $\mathrm{p} K_{\mathrm{A}}$, as was discussed previously (Christ and others, 1.974).

For the runs in which aragonite was suspended in dilute $\mathrm{MgCl}_{2}$ solution, the expression for charge balance is

$$
m \mathrm{HCO}_{3}^{-}=2 m \mathrm{Ca}^{2+}+m \mathrm{CaHCO}_{3}^{+}+2 m \mathrm{Mg}^{2+}+m \mathrm{MgHCO}_{3}^{+}-m \mathrm{Cl}^{-}
$$

(neglecting $\mathrm{CO}_{3}^{2-}, \mathrm{H}^{+}, \mathrm{OH}^{-}, \mathrm{CaOH}^{+}, \mathrm{MgOH}^{+}, \mathrm{CaCO}_{3}^{\circ}$, and $\mathrm{MgCO}_{3}^{\circ}$ ). Corresponding to equation 4 , the ionic strength is given by

$$
\begin{aligned}
& I=1 / 2\left(4 m \mathrm{Ca}^{2+}+4 m \mathrm{Mg}^{2+}+m \mathrm{CaHCO}_{3}^{+}\right. \\
& \left.+m \mathrm{MgHCO}_{3}^{+}+m \mathrm{HCO}_{3}^{-}+m \mathrm{Cl}^{-}\right) .
\end{aligned}
$$
constant $I ; 10$ cycles of iteration were used. Spot checks of the computer results were made by hand calculation.

The iterative scheme followed was to neglect $\mathrm{CaHCO}_{3}^{+}$and $\mathrm{MgHCO}_{3}^{+}$for the first step. Then $m \mathrm{Ca}^{2+}=m \mathrm{Ca}^{2+}(\mathrm{t})$ and $m \mathrm{Mg}^{2+}=m \mathrm{Mg}^{2+}(\mathrm{t})$, where (t) signifies total (that is, analytical concentration); also $2 m \mathrm{Mg}^{2+}=m \mathrm{Cl}^{-}$, whence, from equation 4 , $2 m \mathrm{Ca}^{2+}=m \mathrm{HCO}_{3}^{-}$. From these results, equation 5 yields $I=3\left(\mathrm{mCa}^{2+}+\mathrm{mMg}^{2+}\right)$. For example, for sample A-1-19 (table 2), the value of this provisional $I$ is 0.0138 . With a value of $I$ at hand, values of $\gamma_{i}$ for all the ions are calculated. The next step is to calculate provisional values of $m \mathrm{CaHCO}_{3}^{+}$and $\mathrm{mMgHCO}_{3}^{+}$. The dissociation constant for $\mathrm{CaHCO}_{3}^{+}$is given by the equation

$$
\left[\mathrm{Ca}^{2+}\right]\left[\mathrm{HCO}_{3}^{-}\right] /\left[\mathrm{CaHCO}_{3}^{+}\right]=K_{\mathrm{CaHCO}_{3}^{+}}
$$

or

$$
\left(\gamma \mathrm{Ca}^{2+}\right)\left(m \mathrm{Ca}^{2+}\right)\left(m \mathrm{HCO}_{3}^{-}\right) /\left(m \mathrm{CaHCO}_{3}^{+}\right)=K_{\mathrm{CaHCO}_{3}^{+}},
$$

(where $\gamma \mathrm{HCO}_{3}^{-}=\gamma \mathrm{CaHCO}_{3}^{+}$).

Using the original values of $m \mathrm{Ca}^{2+}$ and $m \mathrm{HCO}_{3}^{-}$, equation 7 is solved for $m \mathrm{CaHCO}_{3}^{+}$. A similar calculation is made for $m \mathrm{MgHCO}_{3}^{+}$. Provisional values of $m \mathrm{Ca}^{2+}$ and $m \mathrm{Mg}^{2+}$ are then obtained by subtracting the value of $\mathrm{mCaHCO}_{3}^{+}$from that of $m \mathrm{Ca}^{2+}(\mathrm{t})$, and the value of $m \mathrm{MgHCO}_{3}^{+}$from that of $m \mathrm{Mg}^{2+}(\mathrm{t})$. Then $m \mathrm{HCO}_{3}^{-}$is obtained using equation 4 , a new $I$ is calculated from equation 5 , and the whole process is repeated until $I$ remains constant.

Values of $\left[\mathrm{CO}_{3}^{2-}\right]$ are determined from the final calculated value of $\left[\mathrm{HCO}_{3}^{-}\right]$, and the measured $\mathrm{pH}$, by means of the equilibrium expression

$$
\left[\mathrm{H}^{+}\right]\left[\mathrm{CO}_{3}^{2-}\right] /\left[\mathrm{HCO}_{3}^{-}\right]=K_{2} \text {. }
$$

The value of $\mathrm{p} K_{2}$ at $90^{\circ} \mathrm{C}$ was taken to be 10.14 (Christ and Hostetler, 1970); for $51^{\circ} \mathrm{C}$ the value 10.17 (Harned and Scholes, 1941.) was used. With values of $\left[\mathrm{Ca}^{2+}\right]$ and $\left[\mathrm{CO}_{3}^{2-}\right]$ at hand, $K_{\mathrm{A}}$ is obtained using equation 1 .

The same procedure was followed in obtaining values of $K_{\mathrm{A}}$ from the runs in which aragonite precipitated from dolomite suspensions, except that $m \mathrm{Cl}^{-}$was taken to be zero in equations 4 and 5 .

It is a noteworthy feature of the pH-charge balance method of calculation that the quantity $P_{\mathrm{CO}_{2}}$ does not enter the calculation, and thus one element of uncertainty is eliminated, as is discussed in the following.

\section{$\mathrm{pH}-\mathrm{P}_{\mathrm{CO}_{2}}$ method for calculating $\mathrm{p} K_{\mathrm{A}}$}

This method is also an iterative one that closely follows the pH-charge balance method, except that explicit account is 
taken of the value of $P_{\mathrm{CO}}$. Following a familiar procedure (see for example, Garrels, Thompson, and Siever, 1960), in the first step, $\left[\mathrm{HCO}_{3}^{-}\right]$and $\left[\mathrm{CO}_{3}^{2-}\right]$ are calculated directly from the measured $\mathrm{pH}$, the nominal $P_{\mathrm{CO}_{2}}$, and the equilibrium expressions

$$
\begin{gathered}
{\left[\mathrm{H}_{2} \mathrm{CO}_{3}\right] / \mathrm{PO}_{2}=K_{0}} \\
{\left[\mathrm{H}^{+}\right]\left[\mathrm{HCO}_{3}^{-}\right] /\left[\mathrm{H}_{2} \mathrm{CO}_{3}\right]=K_{1}} \\
{\left[\mathrm{H}^{+}\right]\left[\mathrm{CO}_{3}^{2-}\right] /\left[\mathrm{HCO}_{3}^{-}\right]=K_{2}}
\end{gathered}
$$

Values of $\mathrm{p} K_{0}, \mathrm{p} K_{1}$, and $\mathrm{p} K_{2}$ at $90^{\circ} \mathrm{C}$ are $1.93,6.41$, and 10.14, respectively (Christ and Hostetler, 1970); for $51^{\circ}, \mathrm{p} K_{0}$, and $\mathrm{p} K_{1}$ are 1.71 and 6.29 (Harned and Davis, 1943), and $\mathrm{p} K_{2}$ is 10.17 (Harned and Scholes, 1941).

The value of $\left[\mathrm{HCO}_{3}^{-}\right]$calculated by means of the relationship

$$
\left[\mathrm{HCO}_{3}^{-}\right]=K_{0} K_{1} P_{\mathrm{CO}_{2}} /\left[\mathrm{H}^{+}\right]
$$

and the value of $\left[\mathrm{CO}_{3}^{2-}\right]$ calculated through the expression

$$
\left[\mathrm{CO}_{3}^{2-}\right]=K_{0} K_{1} K_{2} P_{\mathrm{CO}_{2}} /\left[\mathrm{H}^{+}\right]^{2} .
$$

are taken as the correct values in this method. The iteration proceeds along the same lines as in the $\mathrm{pH}$-charge balance method except that in equation 7 , the term $\mathrm{mHCO}_{3}^{-}$is replaced by $\left[\mathrm{HCO}_{3}^{-}\right] /\left(\gamma \mathrm{CaHCO}_{3}^{+}\right)$, where $\gamma \mathrm{CaHCO}_{3}^{+}=\gamma \mathrm{HCO}_{3}^{-}$.

\section{Results and discussion}

Values of the ion products $\mathrm{p} K_{\mathrm{A}}^{\prime}, \mathrm{p} K_{\mathrm{M}}^{\prime}$, and $\mathrm{p} K_{\mathrm{D}}^{\prime}$ were calculated for each sample listed in table 1 for the dolomite dissolution runs, by both the $\mathrm{pH}$-charge balance method and the $\mathrm{pH}-\mathrm{P}_{\mathrm{CO}_{2}}$ method. To illustrate the data used in the calculation of these ion products, those data appropriate to the last 15 samples of dolomite run D-10 are listed in table 3 for the
$\mathrm{pH}$-charge balance method, and the resulting ion products are listed in table 4. Corresponding data for the $\mathrm{pH}-\mathrm{P}_{\mathrm{CO}_{2}}$ method are listed in tables 5 and 6 . The data of these tables are reasonably typical of all the dolomite dissolution data.

Christ and Hostetler (1970) determined the activity-product constant of magnesite, $K_{\mathrm{M}}$, to be $10^{-9.3}$ at $90^{\circ} \mathrm{C}$. The values of the ion product for magnesite for the samples listed (tables 4 and 6) are all more positive than $10^{-9.3}$, and therefore, the solutions are supersaturated with respect to magnesite. This result is typical of all the dolomite runs. Similarly, the solutions of all the dolomite runs are supersaturated with respect to dolomite. Helgeson (1969) calculated the activityproduct constant of dolomite, $K_{\mathrm{D}}$, to be $10^{-18.9}$ at $90^{\circ} \mathrm{C}$ (based upon a value of $10^{-17.0}$ at $25^{\circ} \mathrm{C}$ ). The values of the ion product of dolomite listed in tables 4 and 6 are all more positive than $10^{-18.9}$.

The results of the calculation of the average activity-product constant of aragonite (as $\mathrm{p} K_{\mathrm{A}}$ ) for each of the dolomite runs and for the aragonite runs are listed in table 7 , for both the $\mathrm{pH}$-charge balance and the $\mathrm{pH}-\mathrm{P}_{\mathrm{CO}_{2}}$ methods of calculation. For the pH-charge balance method of calculation each of the runs has good internal consistency, as shown by the relatively small average deviation from the mean, given by the plus or minus values listed, and there is good agreement among the several runs. In particular, as table 7 shows, the average $\mathrm{p} K_{\mathrm{A}}$ from the dolomite runs (from the direction of supersaturation) is in good agreement with the average $\mathrm{p} K_{\mathrm{A}}$ from the aragonite runs (from the direction of undersaturation).

The values of the average $\mathrm{p} K_{\mathrm{A}}$ calculated by the $\mathrm{pH}-\mathrm{P}_{\mathrm{CO}_{2}}$ method are slightly less internally self-consistent and do not agree as well with one another, from run to run. As we have pointed out elsewhere (Christ and others, 1974), it is difficult to decide whether a nominal, or inferred, value of $P_{\mathrm{CO}_{2}}$ (obtained by measurement of barometric pressure minus the

\begin{tabular}{|c|c|c|c|c|c|c|c|c|c|}
\hline \multirow{2}{*}{ Sample } & \multirow{2}{*}{$\begin{array}{c}\text { Time } \\
\text { (h) }\end{array}$} & $I$ & $\mathrm{Ca}^{2+}$ & $\mathrm{Mg}^{2+}$ & $\mathrm{HCO}_{3}^{-}$ & \multirow{2}{*}{$\gamma \mathrm{Ca}^{2+}$} & \multirow{2}{*}{$\gamma \mathrm{Mg}^{2+}$} & \multirow{2}{*}{$\gamma \mathrm{HCO}_{3}^{-}$} & \multirow{2}{*}{$\begin{array}{l}P_{\mathrm{CO}_{2}} \\
\text { (atm) }\end{array}$} \\
\hline & & \multicolumn{4}{|c|}{ Molality $\times 10^{4}$} & & & & \\
\hline 16 & 2349 & 97 & 8.04 & 22.8 & 65.9 & 0.638 & 0.646 & 0.893 & 0.251 \\
\hline 17 & 3092 & 93 & 8.40 & 21.3 & 63.2 & .643 & .650 & .895 & .253 \\
\hline 18 & 3356 & 90 & 6.76 & 21.9 & 60.0 & .647 & .654 & .896 & .262 \\
\hline 19 & 41.95 & 87 & 8.34 & 19.4 & 58.9 & .651 & .658 & .898 & .265 \\
\hline 20 & 4411 & 91 & 8.86 & 20.1 & 61.5 & .646 & .653 & .896 & .283 \\
\hline 21 & 5031 & 94 & 9.94 & 20.0 & 63.8 & .642 & .649 & .895 & .233 \\
\hline 22 & 5706 & 99 & 9.23 & 22.4 & 67.6 & .635 & .643 & .892 & .276 \\
\hline 23 & 6256 & 94 & 9.12 & 20.9 & 64.0 & .641 & .649 & .895 & .244 \\
\hline 24 & 6427 & 101 & 7.74 & 24.5 & 69.0 & .632 & .640 & .891 & .234 \\
\hline 25 & 6764 & 98 & .5 .50 & 25.9 & 67.0 & .635 & .644 & .893 & .244 \\
\hline 26 & 7523 & 95 & 6.84 & 23.6 & 64.9 & .639 & .647 & .894 & .221 \\
\hline 27 & 7891 & 88 & 6.89 & 21.2 & 59.7 & .649 & .657 & .897 & .239 \\
\hline 28 & 8397 & 81 & 7.61 & 18.4 & 55.1 & .659 & .666 & .901 & .207 \\
\hline 29 & 9643 & 73 & 6.77 & 16.7 & 49.5 & 671 & .678 & .905 & .196 \\
\hline 30 & 10268 & 76 & 6.75 & 17.8 & 51.8 & .666 & .673 & .903 & .199 \\
\hline
\end{tabular}
vapor pressure of water at the temperature of interest)

Table 3.-Data from run D-10 used to calculate the negative logarithms of the ions and ion products listed in table 4; values of the calculated partial pressure of carbon dioxide

[See text for definitions of symbols used; calculations by pH-charge balance method] 
Table 4.-Negative logarithms of the values of the calcium, magnesium, and carbonate ions and of the ion products of aragonite, magnesite, and dolomite, calculated from the data in table 3

[See text for definitions of symbols used]

\begin{tabular}{ccccccc}
\hline Sample & $\mathrm{pCa}$ & $\mathrm{pMg}$ & $\mathrm{pCO}_{3}$ & $\mathrm{p} K_{\mathrm{A}}^{\prime}$ & $\mathrm{p} K_{\mathrm{M}}^{\prime}$ & $\mathrm{p} K_{\mathrm{D}}^{\prime}$ \\
\hline & & & & & & \\
16 & 3.29 & 2.83 & 5.66 & 8.95 & 8.49 & 17.44 .4 \\
17 & 3.27 & 2.86 & 5.70 & 8.97 & 8.56 & 17.53 \\
18 & 3.36 & 2.84 & 5.74 & 9.10 & 8.58 & 17.68 \\
19 & 3.26 & 2.89 & 5.78 & 9.04 & 8.67 & 17.71 \\
20 & 3.24 & 2.88 & 5.77 & 9.01 & 8.65 & 17.66 \\
21 & 3.20 & 2.89 & 5.65 & 8.85 & 8.54 & 17.39 \\
22 & 3.23 & 2.84 & 5.68 & 8.91 & 8.52 & 17.43 \\
23 & 3.23 & 2.87 & 5.67 & 8.90 & 8.54 & 17.44 \\
24 & 3.31 & 2.80 & 5.59 & 8.90 & 8.39 & 17.29 \\
25 & 3.46 & 2.78 & 5.63 & 9.09 & 8.41 & 17.50 \\
26 & 3.36 & 2.82 & 5.62 & 8.98 & 8.44 & 17.42 \\
27 & 3.35 & 2.86 & 5.72 & 9.07 & 8.58 & 17.65 \\
28 & 3.30 & 2.91 & 5.72 & 9.02 & 8.63 & 17.65 \\
29 & 3.34 & 2.94 & 5.79 & 9.13 & 8.73 & 17.86 \\
30 & 3.35 & 2.92 & 5.76 & 9.11 & 8.68 & 17.79 \\
& & & & & & \\
\hline
\end{tabular}

accurately represents a thermodynamic quantity for use in equations 11. and 12. In table 3 for the D-10 run we list values of: $P_{\mathrm{CO}_{2}}$ calculated by the $\mathrm{pH}$-charge balance method using equation 11. Comparison of these values with the corresponding measured values of $P_{\mathrm{CO}}$ listed in table 5 reveals some significant differences. In addition to the uncertainty in the value of $P_{\mathrm{CO}}$ to be used, there is always some uncertainty as to whether even a precisely measured $\mathrm{pH}$ accurately represents the thermodynamic quantity $-\log \left[\mathrm{H}^{+}\right]$. The errors involved in making this assumption were discussed in some detail previously (Christ and others, 1974). In the $\mathrm{pH}$-charge balance method the quantity $\left[\mathrm{H}^{+}\right]$enters to the first power in calculating $\left[\mathrm{CO}_{3}{ }^{2-}\right](\mathrm{eq} 8)$, whereas in the $\mathrm{pH}-\mathrm{P}_{\mathrm{CO}}$ method $\left[\mathrm{H}^{+}\right]^{2}$ appears in equation 12 , for calculating $\left[\mathrm{CO}_{3}{ }^{2-}\right]$. Thus, any error in $\left[\mathrm{H}^{+}\right]$results in twice the error in $\mathrm{p} K_{\mathrm{A}}$ for the $\mathrm{pH}-\mathrm{P}_{\mathrm{CO}_{2}}$ method, compared with $\mathrm{pH}$-charge balance method. In any aqueous solution, electrostatic charge balance must

exist; for example, for the aragonite suspended in $\mathrm{MgCl}_{2}$ solution, equation 4 must be obeyed. Calculations showed that for the $\mathrm{pH}-\mathrm{P}_{\mathrm{CO}_{2}}$ method (where eq 4 is not a starting premise) the ratio of total cations to anions (taken with appropriate multipliers as in eq 4) varied significantly above and below unity, from sample to sample. In summary, the $\mathrm{pH}-\mathrm{P}_{\mathrm{CO}}$ method is not a gool method for calculating ion products. We have considered this method in some detail here only to point out the difficulties lhat it may occasion and to recommend that it be abandon'd where practicable. In arriving at the "best" values for $\mathrm{p} K_{\mathrm{A}}$ at $90^{\circ}$ and $51^{\circ} \mathrm{C}$, we have discarded the values obtained by the pH-P $\mathrm{CO}_{2}$ method.

The average $\mathrm{p} K_{A}$ value from the six' averages for the $90^{\circ} \mathrm{C}$ runs, calculated by lic pH-charge balance method, and listed in table 7 , is $8.95 .1{ }^{\circ}$. have previously discussed in some detail the kinds of errors likely to arise in the determination of the

Table 6.-Negative logarithms of the values of the calcium, magnesium, and carbonate ions and of the ion products of aragonite, magnesite, and dolomite, calculaled from the data in table 5

[Sce text for definitions of symbols used]

\begin{tabular}{lllllll}
\hline Sample & $\mathrm{pCa}$ & $\mathrm{pMg}$ & $\mathrm{pCO} \mathrm{C}_{3}$ & $\mathrm{p} K_{\mathrm{A}}^{\prime}$ & $\mathrm{p} K_{\mathrm{M}}^{\prime}$ & $\mathrm{p} K^{\prime} \mathrm{D}$ \\
\hline & & & & & & \\
16 & 3.29 & 2.83 & 5.64 & 8.93 & 8.47 & 17.40 \\
17 & 3.27 & 2.86 & 5.64 & 8.91 & 8.50 & 17.41 \\
18 & 3.36 & 2.85 & 5.72 & 9.08 & 8.57 & 17.65 \\
19 & 3.27 & 2.90 & 5.74 & 9.01 & 8.64 & 17.65 \\
20 & 3.24 & 2.88 & 5.77 & 9.01 & 8.65 & 17.66 \\
21 & 3.21 & 2.90 & 5.55 & 8.76 & 8.45 & 17.21 \\
22 & 3.23 & 2.84 & 5.66 & 8.89 & 8.50 & 17.39 \\
23 & 3.24 & 2.88 & 5.60 & 8.84 & 8.48 & 17.32 \\
24 & 3.32 & 2.81 & 5.54 & 8.86 & 8.35 & 17.21 \\
25 & 3.46 & 2.79 & 5.56 & 9.02 & 8.35 & 17.37 \\
26 & 3.37 & 2.83 & 5.50 & 8.87 & 8.33 & 17.20 \\
27 & 3.36 & 2.87 & 5.63 & 8.99 & 8.50 & 17.49 \\
28 & 3.31 & 2.92 & 5.60 & 8.91 & 8.52 & 17.43 \\
29 & 3.36 & 2.96 & 5.61 & 8.97 & 8.57 & 17.54 \\
30 & 3.36 & 2.94 & 5.60 & 8.96 & 8.54 & 17.50 \\
& & & & & & \\
\hline
\end{tabular}

Table 5.-Data from run D.iO used to calculate the negative logarithms of the ions and ion products listed in table 6; values of the measured partial pressure of carbon dioxide

[See text for definitions of symbols used; calculations by $\mathrm{pH}-\mathrm{P}_{\mathrm{CO}_{2}}$ method]

\begin{tabular}{|c|c|c|c|c|c|c|c|c|c|}
\hline \multirow{2}{*}{ Sample } & \multirow{2}{*}{$\begin{array}{l}\text { Time } \\
\text { (h) }\end{array}$} & $I$ & $\mathrm{Ca}^{2+}$ & $\mathrm{Mg}^{2+}$ & $\mathrm{HCO}_{3}^{-}$ & \multirow{2}{*}{$\gamma \mathrm{Ca}^{2+}$} & \multirow{2}{*}{$\gamma \mathrm{Mg}^{2+}$} & \multirow{2}{*}{$\gamma \mathrm{HCO}_{3}^{-}$} & \multirow{2}{*}{${ }_{\text {(atm) }}^{P}$} \\
\hline & & \multicolumn{4}{|c|}{ Molality $\times 10^{4}$} & & & & \\
\hline 16 & 2349 & 96 & 7.99 & 22.7 & 69.5 & 0.638 & 0.646 & 0.893 & 0.264 \\
\hline 17 & 3902 & 92 & 8.28 & 21.0 & 71.8 & .644 & .651 & .895 & .285 \\
\hline 18 & 3356 & 89 & 6.72 & 21.8 & 65.0 & .647 & .655 & .897 & .278 \\
\hline 19 & 41.95 & 86 & 8.27 & 19.2 & 63.8 & .652 & .659 & .898 & .286 \\
\hline 20 & 44.11 & 91 & 8.87 & 20.1 & 61.2 & .646 & .653 & .896 & .281 \\
\hline 21. & 5031 & 92 & 9.65 & 19.4 & 81.4 & .64 .4 & .651 & .895 & .293 \\
\hline 22 & 5706 & 99 & 9.17 & 22.3 & 71.6 & .635 & .643 & .892 & .291 \\
\hline 23 & 6256 & 93 & 8.92 & 20.4 & 77.0 & .643 & .651 & .895 & .291 \\
\hline 24 & 6427 & 100 & 7.63 & 24.2 & 77.5 & .633 & .641 & .892 & .261 \\
\hline 25 & 6764 & 97 & 5.38 & 25.3 & 79.4 & .637 & .645 & .893 & .286 \\
\hline 26 & 7532 & 93 & 6.60 & 22.8 & 86.3 & .642 & .650 & .895 & .289 \\
\hline 27 & 7891 & 86 & 6.72 & 20.7 & 74.1 & .651 & .659 & .898 & .294 \\
\hline 28 & 8397 & 79 & 7.35 & 17.8 & 75.2 & .661 & .668 & .901 & .278 \\
\hline 29 & 964.3 & 71 & 6.46 & 16.0 & 76.0 & .674 & .681 & .906 & .294 \\
\hline 30 & 10268 & 74 & 6.46 & 1.7 .0 & 76.7 & .669 & .676 & .904 & .290 \\
\hline
\end{tabular}


Table 7.-Average values of the negative logarithms of the activityproduct constants of aragonite at $90^{\circ}$ and $51^{\circ} \mathrm{C}$ calculated from the analytical data for all samples listed in tables 1 and 2

[See text for definitions of symbols used and methods of calculations]

\begin{tabular}{|c|c|c|c|}
\hline \multirow[b]{2}{*}{$\begin{array}{l}\text { Temp } \\
\left({ }^{\circ} \mathrm{C}\right)\end{array}$} & \multirow[b]{2}{*}{ Run } & \multicolumn{2}{|c|}{ Average $\mathrm{p} K_{\mathrm{A}}$} \\
\hline & & $\begin{array}{c}\text { Calculated by } \\
\text { pH-charge balance } \\
\text { method }\end{array}$ & $\begin{array}{c}\text { Calculated by } \\
\text { pH-PCO } \mathrm{O}_{2} \text { method }\end{array}$ \\
\hline
\end{tabular}

\begin{tabular}{llll}
90 & D-3 & $8.94 \pm 0.02$ & $8.96 \pm 0.02$ \\
90 & D-4 & $8.96 \pm 0.05$ & $9.00 \pm 0.05$ \\
90 & D-5 & $8.93 \pm 0.04$ & $8.96 \pm 0.05$ \\
90 & D-10 & $8.97 \pm 0.05$ & $8.92 \pm 0.06$ \\
90 & A-1 & $8.93 \pm 0.03$ & $8.87 \pm 0.04$ \\
90 & A-2 & $8.94 \pm 0.03$ & $8.87 \pm 0.05$ \\
51 & $2-A-2$ & $8.61 \pm 0.03$ & $8.62 \pm 0.05$ \\
\hline
\end{tabular}

$\mathrm{p} K$ of aragonite or calcite (Christ and others, 1974); on the basis of that discussion we assign an error in $\mathrm{p} K_{\mathrm{A}}$ of \pm 0.05 , so that we choose the "best" value of $\mathrm{p} K_{\mathrm{A}}$ at $90^{\circ} \mathrm{C}$ as $8.95 \pm 0.05$. The $\mathrm{p} K_{\mathrm{A}}$ of the one run at $51^{\circ} \mathrm{C}, 2-\mathrm{A}-2$, is taken as $8.61 \pm 0.05$.

Our calculation of the variation of the value of $\mathrm{p} K_{\mathrm{A}}$ with temperature, from $0^{\circ}$ to $200^{\circ} \mathrm{C}$, has been given in detail elsewhere (Christ and others, 1974). In this calculation we started with a $25^{\circ} \mathrm{C}$ value of $\mathrm{p} K_{\mathrm{A}}$ equal to $8.36 \pm 0.04$ and used appropriate entropy and heat capacity data to calculate values of $\mathrm{p} K_{\mathrm{A}}$ at other temperatures. Our calculated $90^{\circ} \mathrm{C}$ value is 9.16 with an assigned error of \pm 0.08 , compared with the presently measured value of $8.95 \pm 0.05$; for $51^{\circ} \mathrm{C}$ the calculated value is $8.60 \pm 0.08$, compared with our measured value of $8.61 \pm 0.05$. Thus, the $51^{\circ} \mathrm{C}$ measured and calculated values of $\mathrm{p} K_{\mathrm{A}}$ are in excellent agreement, while the measured and calculated values at $90^{\circ} \mathrm{C}$ are in somewhat poorer agreement. We have discussed the various errors that can enter into the calculation of the temperature variation of $\mathrm{p} K_{\mathrm{A}}$ (Christ and others, 1974). Briefly, the method of calculation is such that the larger the temperature difference between $25^{\circ} \mathrm{C}$ and the temperature of interest, the greater the error in the calculated $\mathrm{p} K_{\mathrm{A}}$ at the latter temperature. Thus, at $51^{\circ} \mathrm{C}$ the error in the calculated $\mathrm{p} K_{\mathrm{A}}$ would be expected to be less than that for $90^{\circ} \mathrm{C}$ (although we previously assigned the same error for both temperatures). On the basis of the present study, we are inclined to the belief that the calculated $\mathrm{p} K_{\mathrm{A}}$ at $90^{\circ} \mathrm{C}$ is too large, and that the measured $\mathrm{p} K_{\mathrm{A}}$ is the preferred value.

\section{SUMMARY}

The activity-product constants of aragonite were experimentally determined at $90^{\circ}$ and $51^{\circ} \mathrm{C}$. For the $90^{\circ} \mathrm{C}$ measurements, equilibrium between aragonite and the aqueous phase was attained from the direction of supersaturation for four separate dolomite dissolution runs and from the direction of undersaturation for two separate runs starting with aragonite suspended in dilute $\mathrm{MgCl}_{2}$ solutions. Excellent agreement among the six runs was attained; the value of $\mathrm{p} K_{\mathrm{A}}$ at $90^{\circ} \mathrm{C}$ is 8.95 \pm 0.05 . One run at $51^{\circ} \mathrm{C}$ starting with aragonite suspended in dilute $\mathrm{MgCl}_{2}$ solution yielded the value of $\mathrm{pK}$ 的 $8.61 \pm 0.05$.

\section{ACKNOWLEDGMENTS}

We are grateful to Professor Donald Langmuir, Pennsylvania State University, for a preprint of the manuscript by Jacobson and Langmuir (1974), and to K. A. McGee, U.S. Geological Survey, for his help with some of the experimental work. We also thank R. A. Gulbrandsen and C. E. Roberson, U.S. Geological Survey, for reviewing the manuscript. This research was supported in part by the Petroleum Research Fund of the American Chemical Society, Grant 5052-AC 2, and by the National Science Foundation, Grant GA 31231.

\section{REFERENCES CITED}

Berner, R. A., 1971, Principles of chemical sedimentology: New York, McGraw-Hill, $240 \mathrm{p}$.

Bischoff, J. L. and Fyfe, W. S., 1968, Catalysis, inhibition, and the calcite-aragonite problem, [Pt.] 1, The aragonite-calcite transformation: Am. Jour. Sci., v. 266, p. 65-79.

Christ, C. L., and Hostetler, P. B., 1970, Studies in the system $\mathrm{MgO}-\mathrm{SiO}_{2}-\mathrm{CO}_{2}-\mathrm{H}_{2} \mathrm{O}$, [Pt.] 2, The activity-product constant of magnesite: Am. Jour. Sci., v. 268, p. 439-453.

Christ, C. L., Hostetler, P. B., and Siebert, R. M., 1974, Stabilities of calcite and aragonite: U.S. Geol. Survey Jour. Research, v. 2, no. 2, p. 175-184.

Coleman, R. G., and Lee, D. E., 1962, Metamorphic aragonite in the glaucophane schists of Cazadero, California: Am. Jour. Sci., v. 260, p. $577-595$.

Folk, R. L., 1973, Carbonate petrography in the post-Sorbian age, in Ginsburg, R. N., ed., Evolving concepts in sedimentology: Baltimore, The Johns Hopkins Press, p. 118-158.

Garrels, R. M., and Christ, C. L., 1965, Solutions, minerals and equilibria: New York, Harper and Row, 450 p.

Garrels, R. M., Thompson, M. E., and Siever, Raymond, 1960, Stability of some carbonates at $25^{\circ} \mathrm{C}$ and one atmosphere total pressure: Am. Jour. Sci., v. 258, p. 402-418.

Harned, H. S., and Davis, Raymond, Jr., 1943, The ionization constant of carbonic acid in water and the solubility of carbon dioxide in water and aqueous salt solutions from 0 to $50^{\circ} \mathrm{C}$ : Am. Chem. Soc. Jour., v. 65, p. 2030-2037.

Harned, H. S., and Scholes, S. R., Jr., 1941, The ionization constant of $\mathrm{HCO}_{3}^{-}$from 0 to $50^{\circ} \mathrm{C}$ : Am. Chem. Soc. Jour., v. 63, p. 1706-1709.

Helgeson, H. C., 1967, Solution chemistry and metamorphism, in Abelson, P. H., ed., Researches in geochemistry: New York, John Wiley, v. 2, p. 362-404.

1969, Thermodynamics of hydrothermal systems at elevated temperatures and pressures: Am. Jour. Sci., v. 267, p. 729-804.

Hostetler, P. B., 1963, The stability and surface energy of brucite in water at $25^{\circ} \mathrm{C}$ : Am. Jour. Sci., v. 261, p. 238-258.

Hostetler, P. B., and Christ, C. L., 1968, A temperature-controlled water bath for mineral solubility studies, in Geological Survey research 1968: U.S. Geol. Survey Prof. Paper 600-D, p. D21.7-D221.

Jacobson, R. L., and Langmuir, Donald, 1974, Dissociation constants of calcite and $\mathrm{CaHCO}_{3}^{+}$: Geochim. et Cosmochim Acta, v. 38, p.301-318.

Katz, Amitai, 1973, The interaction of magnesium with calcite during crystal growth at $25-90^{\circ} \mathrm{C}$ and one atmosphere: Geochim. et Cosmochim. Acta, v. 37, p. 1563-1586. 
Katz, Amitai, Sass, E., Starinsky, A., and Holland, H. D., 1972, Strontium behavior in the aragonite-calcite transformation: Geochim. et Cosmochim. Acta, v. 36, p. 481-496.

Langmuir, Donald, 1964, Stability of carbonates in the system CaO-MgO- $-\mathrm{CO}_{2} \cdot \mathrm{H}_{2} \mathrm{O}$ : Harvard Univ., Cambridge, Mass., Ph. D. thesis, $142 \mathrm{p}$.

1968, Stability of calcite based on aqueous solubility measurements: Geochim. et Cosmochim. Acta, v. 32, p. 835-851.

Lippmann, Friedrich, 1973, Sedimentary carbonate minerals: New York, Springer-Verlag, 228 p.

McGee, K. A., and Hostetler, P. B., 1974, Studies in the system MgO-SiO $-\mathrm{CO}_{2}-\mathrm{H}_{2} \mathrm{O}$, [Pt.] 4; The stability of $\mathrm{MgOH}^{+}$from $10^{\circ}$ to $90^{\circ} \mathrm{C}$ : Am. Jour. Sci. (In press.)
Neuerberg, G. J., 1951, Minerals of the Santa Monica Mountains, Los Angeles City: Am. Mineralogist, v. 36, p. 156-160.

Palache, Charles, Berman, Harry, and Frondel, Clifford, 1951, Dana's system of mineralogy [7th ed.]; New York, John Wiley, v. 2, $1,124 \mathrm{p}$.

Sillén, L. G., and Martel, A. E., 1964, Stability constants of metal-ion complexes: Chem. Soc. [London] Spec. Pub. 17, 754 p.

Taft, W. H., 1967, Physical chemistry of formation of carbonates, in Chilinger, G. V., Bissell, H. J., and Fairbridge, R. W., eds., Developments in sedimentology [volume] 9B: New York, Elsevier, p. 151-167..

Weast, R. C., ed., 1967, Handbook of chemistry and physics [48th ed.]: Cleveland, Chemical Rubber Publishing Co., 1,937 p. 



\title{
EQUILIBRIA OF CINNABAR, STIBNITE, AND SATURATED SOLUTIONS IN THE SYSTEM HgS-Sb ${ }_{2} \mathrm{~S}_{3}-\mathrm{Na}_{2} \mathrm{~S}-\mathrm{H}_{2} \mathrm{O}$ FROM $150^{\circ}$ TO $250^{\circ} \mathrm{C}$ AT 100 BARS, WITH IMPLICATIONS CONCERNING ORE GENESIS
}

\author{
By R. E. LEARNED, GEORGE TUNELL, ${ }^{1}$ and F. W. DICKSON, ${ }^{2}$ \\ Denver, Colo., Santa Barbara, Calif., Palo Alto, Calif.
}

\begin{abstract}
The common occurrence of cinnabar and stibnite in well-defined districts in the same epithermal environments suggests that similar physiochemical processes are responsible for the genesis of the two minerals; however, cinnabar and stibnite tend to be segregated within these districts and also within individual deposits that contain both minerals. Where cinnabar and stibnite occur in contact, textural evidence indicates that cinnabar is generally younger, al though some textures suggest overlap of deposition. To better understand the physicochemical processes involved in the formation of cinnabar and stibnite deposits, we investigated the solubilities of cinnabar and stibnite in aqueous $\mathrm{Na}_{2} \mathrm{~S}$ solutions that were simultancously saturated with both cinnabar and stibnite at concentrations from 0.384 percent $(0.04 .92 \mathrm{~mol} / \mathrm{kg})$ to 1.772 percent $(0.227 \mathrm{~mol} / \mathrm{kg}) \mathrm{Na}_{2} \mathrm{~S}$ at temperatures from $150^{\circ}$ to $250^{\circ} \mathrm{C}$, at 100 bars pressure. The ratio of dissolved $\mathrm{Sb}_{2} \mathrm{~S}_{3}$ to $\mathrm{HgS}$ under most conditions is larger than 25:1 moles per mole. We conclude that alkaline sulfide solutions could not transport geologically appreciable amounts of $\mathrm{HgS}$ while they are saturated with stibnite; major amounts of $\mathrm{HgS}$ could only be transported in solutions that are undersaturated with stibnite. Solubility behavior of $\mathrm{HgS}$ and $\mathrm{Sb}_{2} \mathrm{~S}_{3}$ is thus a possible mechanism for the segregation of cinnabar and stibnite, especially when the conduit system is modified during the episode of mincralization. The deposition of stibnite before that of cinnabar in most places but with minor overlapping deposition in some places is in accord with deductions made from the solubility studies.
\end{abstract}

The association of cinnabar and stibnite is sufficiently common and their environments of deposition are sufficiently similar that a genetic relationship is indicated in some occurrences. Our field observations and petrographic studies of several mercury-antimony districts in the Western United States have led us to some generalizations regarding the nature of the mineralization:

1. Within these districts cinnabar and stibnite tend to be segregated into deposits in which one of the minerals greatly predominates.

\footnotetext{
${ }^{1}$ Department of Geological Sciences, University of California.

${ }^{2}$ Department of Geology, Stanford University.
}

2. Even within given deposits, in which both cinnabar and stibnite occur, the two minerals tend to be segregated rather than to be evenly distributed through the deposit.

3. Where textural relationships indicate sequential deposition, cinnabar is usually the younger mineral.

4. Where cinnabar and stibnite are in contact, their crystals in some occurrences are intimately intergrown, suggesting overlap of deposition.

Some questions suggested by the field and petrographic observations are as follows:

1. Why do cinnabar and stibnite occur in similar depositional environments?

2. Why are cinnabar and stibnite generally separated spatially and temporally within districts and within individual deposits?

3. To what process can the relatively uncommon occurrence of overlapping deposition of cinnabar and stibnite be attributed?

In an effort to answer these questions, and to more completely understand the physicochemical systems relevant to epithermal ore genesis, we have determined the solubilities of cinnabar and stibnite in aqueous $\mathrm{Na}_{2} \mathrm{~S}$ solutions simultaneously saturated with both cinnabar and stibnite at $\mathrm{Na}_{2} \mathrm{~S}$ concentrations of 0.384 wt percent $(0.0492 \mathrm{~mol} / \mathrm{kg}), 0.858 \mathrm{wt}$ percent $(0.110 \mathrm{~mol} / \mathrm{kg})$, and 1.772 wt percent $(0.2270 \mathrm{~mol} / \mathrm{kg})$ at temperatures of $150^{\circ}, 200^{\circ}$, and $250^{\circ} \mathrm{C}$ at 100 bars pressure.

\section{PREVIOUS WORK}

No previous studies of the quaternary system $\mathrm{HgS}-\mathrm{SB}_{2} \mathrm{~S}_{3}-\mathrm{Na}_{2} \mathrm{~S}-\mathrm{H}_{2} \mathrm{O}$ have been reported. Parts of the ternary system $\mathrm{HgS}-\mathrm{Na}_{2} \mathrm{~S}-\mathrm{H}_{2} \mathrm{O}$ have been studied by Knox (1906), Saukov (1946), Dickson and Tunell (1958), Dickson (1964), and Barnes, Romberger, and Stemprok (1967). Parts of the ternary system $\mathrm{Sb}_{2} \mathrm{~S}_{3}-\mathrm{Na}_{2} \mathrm{~S}-\mathrm{H}_{2} \mathrm{O}$ have been investigated by Fiala and Konopik (1950), Norton (1964), and Arntson, 
Dickson, and Tunell (1966). Homogeneous equilibria among ionic species of $\mathrm{Sb}$ in $\mathrm{Na}_{2} \mathrm{~S}$ solutions were studied by Shestitko and Demina (1971). Only the studies by Dickson (1964) and Norton (1964) were made over ranges of temperature, pressure, and $\mathrm{Na}_{2} \mathrm{~S}$ concentration corresponding to those of this study.

\section{EXPERIMENTAL PROCEDURES}

\section{Equipment}

The experimental work was done with the hydrothermal solution equipment of Dickson, Blount, and Tunell (1963). The equipment consists of a deformable $300-\mathrm{ml}$ Teflon sample cell held in a $600-\mathrm{ml}$ stainless-steel pressure vessel. Temperatures were established and controlled by heating the assemblage in an electric resistance furnace equipped with a standard off-on type regulator. Temperatures were determined within an accuracy of $\pm 2^{\circ} \mathrm{C}$ by electromotive force measurements of an alumel-chromel thermocouple positioned within a recess in the closure piece of the pressure vessel. Confining pressure was developed on the sample by pumping water into the space surrounding the sample cell within the enclosing pressure vessel. Pressures were measured with a calibrated HeiseBourdon gage within \pm 4 bars. The equipment permits withdrawal of an internally filtered liquid sample with only negligible disturbance of the experimental conditions.

\section{Materials}

$\mathrm{Na}_{2} \mathrm{~S}$ solutions were prepared by dissolving clear crystals of reagent-grade $\mathrm{Na}_{2} \mathrm{~S} \cdot 9 \mathrm{H}_{2} \mathrm{O}$ (J. T. Baker Co.) in de-aerated purified liquid $\mathrm{H}_{2} \mathrm{O}$. The $\mathrm{HgS}$ used was reagent-grade commercially available red $\mathrm{HgS}$ powder (Allied Chemical Co.) that yielded the $X$-ray pattern of natural cinnabar. Crystalline $\mathrm{Sb}_{2} \mathrm{~S}_{3}$ was prepared by the reaction of reagent-grade $\mathrm{Sb}$ (Mallinkrodt Chemical Works) with high purity S provided by the Freeport Sulphur Co. in sealed, evacuated Pyrex glass tubes at temperatures above $300^{\circ} \mathrm{C}$. Excess $\mathrm{S}$, present after the reaction, was removed by washing with $\mathrm{CS}_{2}$. The $\mathrm{Sb}_{2} \mathrm{~S}_{3}$ produced in this way was homogeneous, and it had the stoichiometric composition and X-ray diffraction pattern of natural stibnite. Five samples were analyzed chemically for $\mathrm{Sb}$ and were found to contain the correct stoichiometric amount within an accuracy of \pm 0.1 percent.

\section{Equilibration}

The Teflon sample cell was loaded with powdered red $\dot{\mathrm{H} g S}$, crystalline $\mathrm{Sb}_{2} \mathrm{~S}_{3}$, and aqueous $\mathrm{Na}_{2} \mathrm{~S}$ solution under a nitrogen atmosphere free of oxygen and carbon dioxide. The sample cell-pressure vessel assemblage was placed in the furnace and brought to the temperature of the experiment. Long periods of time, of the order of a month, are required to equilibrate stibnite with aqueous $\mathrm{Na}_{2} \mathrm{~S}$ solutions at $100^{\circ} \mathrm{C}$. Reaction rates were hastened by rocking the furnace and the contained equipment to mix the solid phases with the liquid. Even with the rocking, 10 days were required to attain steady-state solution concentrations at $150^{\circ} \mathrm{C}$, and 2 days at $200^{\circ} \mathrm{C}$. The reaction proceeded more rapidly at $250^{\circ} \mathrm{C}$; a steady state was probably attained in a few hours, although in all experiments we allowed at least 1 day. Samples of solution were withdrawn from the equipment at regular intervals of time until consecutive samples showed the same $\mathrm{Sb}$ and $\mathrm{Hg}$ contents. A few points on the saturation curves at $200^{\circ} \mathrm{C}$ were determined by approaching the steady state from both undersaturated and supersaturated conditions. Evidence that the steady-state values approximated equilibrium solubility values consisted of the smoothness of the plotted data and the ability to reverse the reaction at $200^{\circ} \mathrm{C}$.

\section{Sampling and analysis}

Samples were extracted from the sample cell for subsequent analysis by opening the valve at the terminus of the Teflonlined stainless-steel tubing entering the sample cell, water being pumped simultaneously into the cavity around the cell to maintain constant pressure. The sample was thus forced through a sintered Teflon filter at the top of the cell into the exit tube and then into a chilled glass container. Most of the samples weighed about $30 \mathrm{~g}$; the insertion of $30 \mathrm{~g}$ of cool water into the equipment during sampling to compensate for the withdrawn sample caused only a negligible drop in temperature.

Weighed portions of samples extracted from the sample cell were analyzed for $\mathrm{Hg}, \mathrm{Sb}$, and $\mathrm{Na} ; \mathrm{H}_{2} \mathrm{O}$ was determined by subtracting the sum of the $\mathrm{HgS}, \mathrm{Sb}_{2} \mathrm{~S}_{3}$, and $\mathrm{Na}_{2} \mathrm{~S}$ percentages from 100 percent. For the $\mathrm{Hg}$ analyses, 10 - to $40 \mathrm{~g}$ portions were poured into beakers from a weight buret. Quantitative separation of $\mathrm{Hg}$ from $\mathrm{Sb}$ was accomplished by the method of Hiltner and Gittel (1935) in which Sb is retained in solution as a soluble tartrate and $\mathrm{Hg}$ is precipitated as a sulfide during oxidation of the solutions. Hg was determined gravimetrically as $\mathrm{HgS}$. The filtrate containing the $\mathrm{Sb}$ was discarded because the presence of tartrate interferes with the $\mathrm{Sb}$ analysis. For the $\mathrm{Sb}$ determinations, 4- to $12 \mathrm{~g}$ portions were weighed into beakers. $\mathrm{Hg}$ and $\mathrm{Sb}$ were séparated from $\mathrm{Na}$ by acidification of the samples with dilute $\mathrm{HCl}$ to precipitate the $\mathrm{HgS}$ and $\mathrm{Sb}_{2} \mathrm{~S}_{3}$. The resulting $\mathrm{HgS}$ and $\mathrm{Sb}_{2} \mathrm{~S}_{3}$ precipitates were collected in fritted Pyrex crucibles and the filtrate was analyzed for $\mathrm{Na}$ as $\mathrm{Na}_{2} \mathrm{SO}_{4}$ by the comnion gravimetric technique. The $\mathrm{Sb}_{2} \mathrm{~S}_{3}$ was separated from most of the $\mathrm{HgS}$ by repeated washing of the sulfide precipitates on the filter disk with $\left(\mathrm{NH}_{4}\right)_{2} \mathrm{~S}$ solution which quantitatively transformed the $\mathrm{Sb}$ into a soluble form. The small amount of $\mathrm{HgS}$ that accompanied the $\mathrm{Sb}$ into solution did not interfere with the subsequent $\mathrm{Sb}$ analysis of the filtrate. Sb content was determined by the bromate titrimetric method of Smith and May (1941). The estimated precision of each analytical procedure is indicated in table 1. 
Table 1.-Concentrations of $\mathrm{HgS}$ and $\mathrm{Sb}_{2} \mathrm{~S}_{3}$ in solutions simultaneously saturated with cinnabar and stibnite at 100-bars pressure and at several $\mathrm{Na}_{2} \mathrm{~S}$ concentrations and several temperatures in the system $\mathrm{HgS-Sb_{2 }} \mathrm{S}_{3}-\mathrm{Na}_{2} \mathrm{~S}-\mathrm{H}_{2} \mathrm{O}$

[Estimated precision given in parentheses. Each reported concentration is an averaged value of several experimental determinations]

\begin{tabular}{|c|c|c|c|c|c|c|c|}
\hline \multirow{3}{*}{$\begin{array}{l}\text { Temperature } \\
\left({ }^{\circ} \mathrm{C}\right)\end{array}$} & \multicolumn{4}{|c|}{ Weight percent } & \multicolumn{3}{|c|}{ Moles per kilogram } \\
\hline & $\mathrm{Na}_{2} \mathrm{~S}$ & $\mathrm{HgS}$ & $\mathrm{Sb}_{2} \mathrm{~S}_{3}$ & $\mathrm{H}_{2} \mathrm{O}^{1}$ & $\mathrm{Na}_{2} \mathrm{~S}$ & $\mathrm{HgS}$ & $\mathrm{Sb}_{2} \mathrm{~S}_{3}$ \\
\hline & $( \pm 0.006)$ & $( \pm 0.001)$ & $( \pm 0.002)$ & $( \pm 0.009)$ & $( \pm 0.001)$ & $( \pm 0.00005)$ & $( \pm 0.0001)$ \\
\hline 150 & 1.772 & 0.068 & 3.878 & 94.282 & 0.2270 & 0.0029 & 0.1142 \\
\hline 200 & 1.772 & .084 & 4.082 & 94.068 & .2270 & .0036 & .1202 \\
\hline 250 & 1.772 & .123 & 4.431 & 93.674 & .2270 & .0053 & .1304 \\
\hline 150 & .858 & .023 & 1.554 & 97.565 & .110 & .0010 & .0457 \\
\hline 200 & .858 & .028 & 1.689 & 97.425 & .110 & .0012 & .04 .97 \\
\hline $200^{2}$ & .858 & .028 & 1.697 & 97.417 & .110 & .0012 & .0500 \\
\hline 250 & .858 & .039 & 1.840 & 97.263 & .110 & .001 .7 & .0542 \\
\hline $150 \ldots$ & .384 & .0080 & .579 & 99.029 & .0492 & .00035 & .01704 \\
\hline$\cdots$ & .384 & .0089 & .636 & 98.971 & .0492 & .00039 & .01873 \\
\hline 250 & .384 & .0127 & .724 & 98.879 & .0492 & .00055 & .02130 \\
\hline
\end{tabular}

${ }^{1} \mathrm{H}_{2} \mathrm{O}$ determined by subtracting the sum of $\mathrm{Na}_{2} \mathrm{~S}, \mathrm{HgS}$, and $\mathrm{Sb}_{2} \mathrm{~S}_{3}$ percentages from 100 percent.

${ }^{2}$ Equilibrium approached from supersaturation.

The solid phases in the sample cell were examined microscopically and were checked by means of an X-ray diffraccometer at the termination of each series of experiments at each $\mathrm{Na}_{2} \mathrm{~S}$ concentration. Cinnabar and stibnite were the only solid phases found.

\section{EXPERIMENTAL RESULTS}

The results of the solubility study are presented in table 1 and figures 1-4. The values reported represent determinations of concentrations of $\mathrm{HgS}$ and $\mathrm{Sb}_{2} \mathrm{~S}_{3}$ in aqueous $\mathrm{Na}_{2} \mathrm{~S}$ solutions simultaneously saturated with both cinnabar and stibnite. They are average values of repeated determinations of concentrations in solutions that had attained a steady state. From these data the following conclusions have been drawn: 1. Stibnite is highly soluble in solutions of the quaternary system $\mathrm{HgS}-\mathrm{Sb}_{2} \mathrm{~S}_{3}-\mathrm{Na}_{2} \mathrm{~S}-\mathrm{H}_{2} \mathrm{O}$, in contrast to cinnabar, which is more than an order of magnitude less soluble than stibnite (figs. 1 and 2).

2. Stibnite is only slightly less soluble in solutions of the quaternary system than under corresponding conditions in solutions of the ternary system $\mathrm{Sb}_{2} \mathrm{~S}_{3}=\mathrm{Na}_{2} \mathrm{~S}-\mathrm{H}_{2} \mathrm{O}$. In contrast, cinnabar solubility is much less in solutions of the quaternary system as compared to that in solutions of the ternary system $\mathrm{HgS}-\mathrm{Na}_{2} \mathrm{~S} \cdot \mathrm{H}_{2} \mathrm{O}$. Relative solubilities of cinnabar and stibnite in solutions of the quaternary system and in solutions of both ternary systems are presented for comparison purposes in figure 2.

3. Stibnite solubility in aqueous $\mathrm{Na}_{2} \mathrm{~S}$ solutions saturated with both stibnite and cinnabar increases at a slightly increasing rate as a function of $\mathrm{Na}_{2} \mathrm{~S}$ concentration in a manner similar to stibnite solubility in aquecus $\mathrm{Na}_{2} \mathrm{~S}$
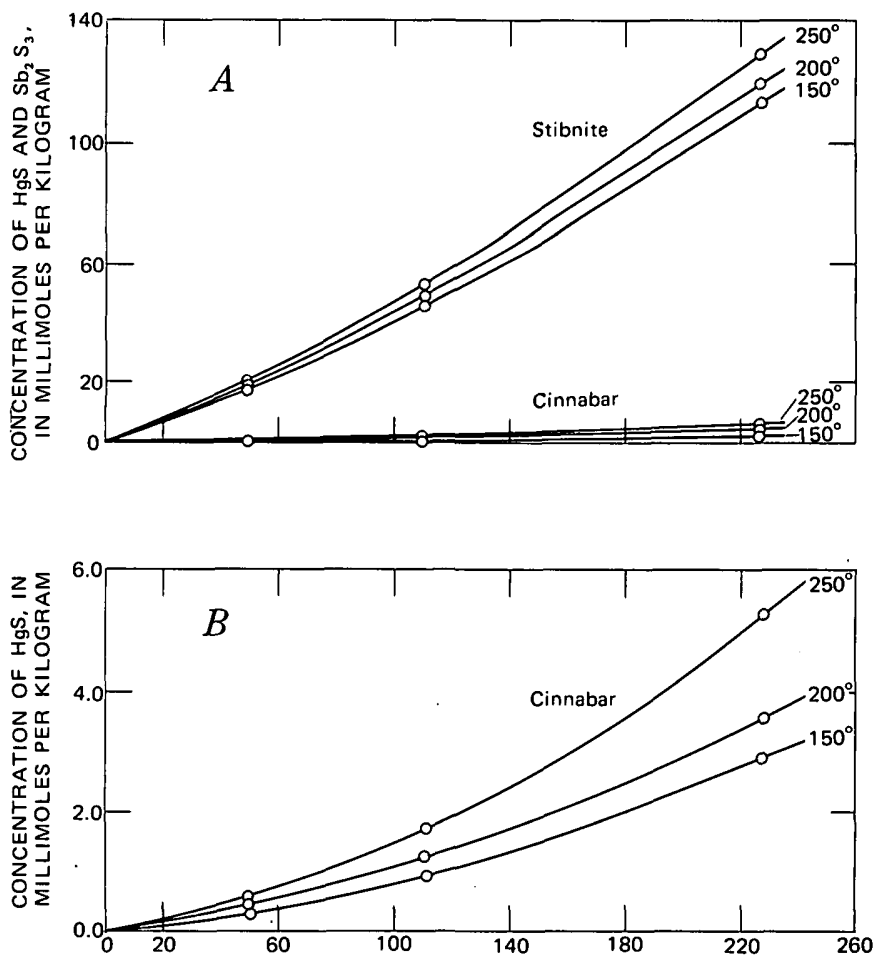

CONCENTRATION OF $\mathrm{Na}_{2} \mathrm{~S}$, IN MILLIMOLES PER KILOGRAM

Figure 1.-Solubilities of cinnabar and stibnite in solutions simultaneously saturated with both minerals in the system $\mathrm{HgS}-\mathrm{Sb}_{2} \mathrm{~S}_{3}-\mathrm{Na}_{2} \mathrm{~S}-\mathrm{H}_{2} \mathrm{O}$ at $150^{\circ}, 200^{\circ}$, and $250^{\circ} \mathrm{C}$ at 100 bars. (The cinnabar saturation curves of figures $1 A$ and $1 B$ are plots of the same $\cdot$ data; only the vertical scale of figure $1 B$ is expanded for clarity.)

solutions saturated with stibnite alone (fig. 2).

4. Cinnabar solubility in aqueous $\mathrm{Na}_{2} \mathrm{~S}$ solutions saturated with both cinnabar and stibnite increases at an increasing rate as a function of $\mathrm{Na}_{2} \mathrm{~S}$ concentration in a manner 


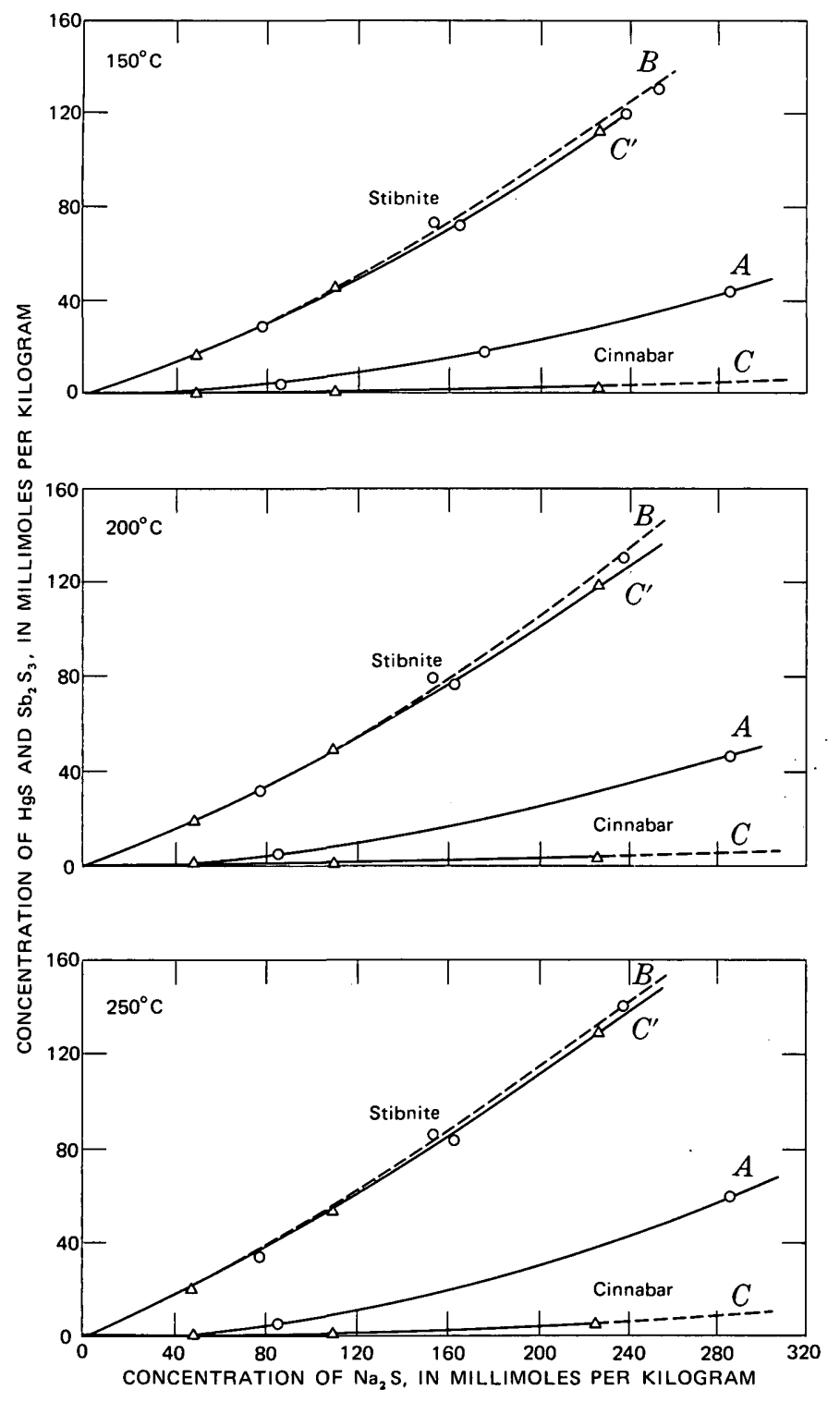

Figure 2.-Solubility of cinnabar in solutions in the ternary system $\mathrm{HgS}-\mathrm{Na}_{2} \mathrm{~S}^{-} \mathrm{H}_{2} \mathrm{O}$ (curves $A$ ) and solubility of stibnite in solutions in the ternary system $\mathrm{Sb}_{2} \mathrm{~S}_{3}-\mathrm{Na}_{2} \mathrm{~S}-\mathrm{H}_{2} \mathrm{O}$ (curves $B$ ) shown for comparison with the solubilities of cinnabar and stibnite in solutions simultaneously saturated with both minerals in the quaternary system $\mathrm{HgS} \mathrm{Sb}_{2} \mathrm{~S}_{3}-\mathrm{Na}_{2} \mathrm{~S}-\mathrm{H}_{2} \mathrm{O}$ (curves $C$ and $C^{\prime}$ ) at $150^{\circ}, 200^{\circ}$, and $250^{\circ} \mathrm{C}$ at 100 bars. (Data of ternary systems are from Dickson (1964) and Norton (1964).)

similar to cinnabar solubility in aqueous $\mathrm{Na}_{2} \mathrm{~S}$ solutions saturated with cinnabar alone (figs. $1 B$ and 2 ).

5. Stibnite solubility in aqueous $\mathrm{Na}_{2} \mathrm{~S}$ solutions saturated with both cinnabar and stibnite increases at an increasing rate as a function of temperature (fig. 3 ).

6. Cinnabar solubility in aqueous $\mathrm{Na}_{2} \mathrm{~S}$ solutions saturated with both cinnabar and stibnite increases at an increasing rate as a function of temperature in a manner similar to cinnabar solubility in solutions saturated with cinnabar alone (fig. 4).

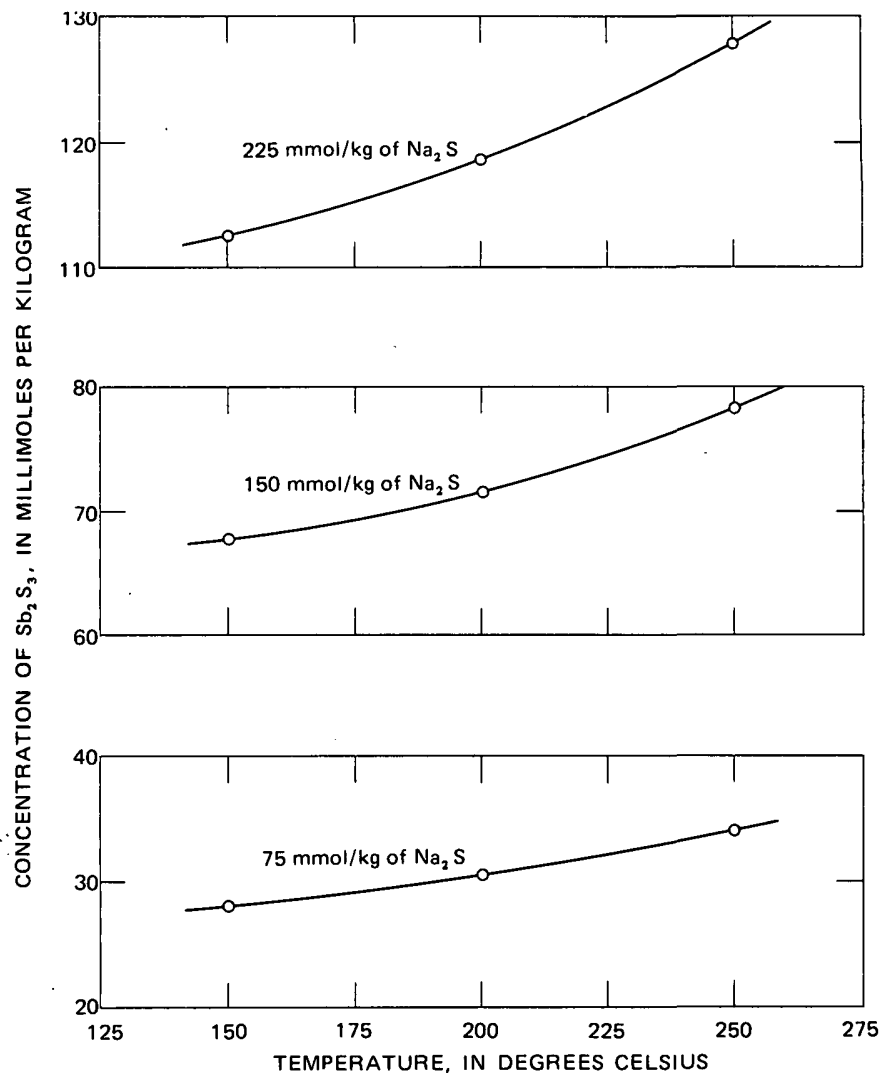

Figure 3.-Solubility of stibnite in solutions simultaneously saturated with both cinnabar and stibnite in the quaternary system $\mathrm{HgS}-\mathrm{Sb}_{2} \mathrm{~S}_{3}-\mathrm{Na}_{2} \mathrm{~S}-\mathrm{H}_{2} \mathrm{O}$ as a function of temperature at 100 bars and various $\mathrm{Na}_{2} \mathrm{~S}$ concentrations.

\section{Effects of $\mathrm{Na}_{2} \mathrm{~S}$ concentration}

The curves representing the mutual solubilities of cinnabar and stibnite as functions of $\mathrm{Na}_{2} \mathrm{~S}$ concentration in solutions in the system $\mathrm{HgS}-\mathrm{Sb}_{2} \mathrm{~S}_{3}-\mathrm{Na}_{2} \mathrm{~S}-\mathrm{H}_{2} \mathrm{O}$ appear in figures $\mathrm{l}$ and 2 .

At each temperature the saturation curve of cinnabar in solutions in the quaternary system $\mathrm{HgS}-\mathrm{Sb}_{2} \mathrm{~S}_{3}-\mathrm{Na}_{2} \mathrm{~S} \cdot \mathrm{H}_{2} \mathrm{O}$ is less convex toward the field of unsaturated solution than is the corresponding saturation curve of cinnabar in the ternary system $\mathrm{HgS}-\mathrm{Na}_{2} \mathrm{~S}-\mathrm{H}_{2} \mathrm{O}$; cinnabar solubilities increase at increasing rates as functions of $\mathrm{Na}_{2} \mathrm{~S}$ concentration in both systems, but the rates are diminished by the presence of stibnite. Even so, the effects of dilution in the quaternary system could be the precipitation of major fractions of the dissolved $\mathrm{HgS}$. For example, at $150^{\circ} \mathrm{C}$ and 100 bars, a 1:1 dilution of a $0.1 \mathrm{~mol} / \mathrm{kg}$ aqueous $\mathrm{Na}_{2} \mathrm{~S}$ solution saturated with both cinnabar and stibnite would cause the precipitation of about one-fourth of the dissolved $\mathrm{HgS}$.

At each temperature, the saturation curve of stibnite for solutions saturated with both stibnite and cinnabar in the system $\mathrm{HgS}-\mathrm{Sb}_{2} \mathrm{~S}_{3}-\mathrm{Na}_{2} \mathrm{~S}-\mathrm{H}_{2} \mathrm{O}$ and the saturation curve of stibnite for solutions in the system $\mathrm{Sb}_{2} \mathrm{~S}_{3} \cdot \mathrm{Na}_{2} \mathrm{~S}-\mathrm{H}_{2} \mathrm{O}$ are separated only slightly, but the apparent scatter in the data of Norton (1964) for the ternary system makes the exact 

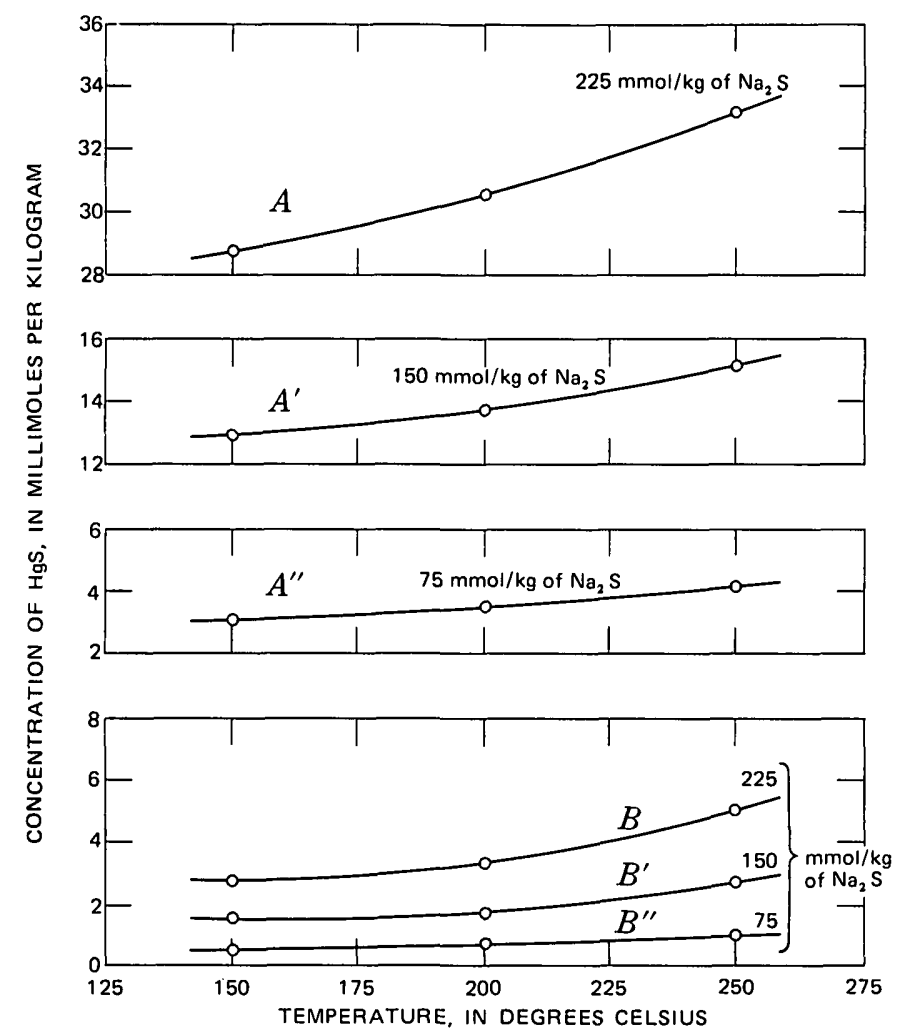

Figure 4.--Solubility of cinnabar in solutions in the ternary system $\mathrm{HgS}-\mathrm{Na}_{2} \mathrm{~S}-\mathrm{H}_{2} \mathrm{O}$ (curves $A, A^{\prime}, A^{\prime \prime}$ ) and in solutions simultaneously saturated with both cinnabar and stibnite in the quaternary system $\mathrm{HgS}-\mathrm{Sb}_{2} \mathrm{~S}_{3}-\mathrm{Na}_{2} \mathrm{~S}_{2} \mathrm{H}_{2} \mathrm{O}$ (curves $B, B^{\prime}, B^{\prime \prime}$ ) as a function of temperature at 100 bars and various $\mathrm{Na}_{2} S$ concentrations.

position of the saturation curves in the ternary system a little uncertain. For this reason, the saturation curves for stibnite in the ternary system are dashed in figure 2. However, stibnite solubilities in both systems increase at increasing rates as functions of $\mathrm{Na}_{2} \mathrm{~S}$ concentration and the rates are probably about the same. The effects of dilution in the quaternary system could be the precipitation of major fractions of the dissolved $\mathrm{Sb}_{2} \mathrm{~S}_{3}$. For example, at $150^{\circ} \mathrm{C}$ and 100 bars, a $1: 1$ dilution of a $0.1 \mathrm{~mol} / \mathrm{kg} \mathrm{Na} \mathrm{Na}_{2} \mathrm{~S}$ solution saturated with both cinnabar and stibnite would cause the precipitation of about one-fifth of the dissolved $\mathrm{Sb}_{2} \mathrm{~S}_{3}$.

\section{Effects of temperature}

The effects of temperature upon the solubilities of cinnabar and stibnite in solutions simultaneously saturated with both minerals are shown graphically in figures 3 and 4 . At the $\mathrm{Na}_{2} \mathrm{~S}$ concentrations studied, the solubility of stibnite in solutions saturated with both stibnite and cinnabar increases at an increasing rate as a function of temperature from $150^{\circ}$ to $250^{\circ} \mathrm{C}$ (fig. 3).

The curves of figure 4 show that the solubility of cinnabar in solutions saturated with both cinnabar and stibnite increases at an increasing rate as a function of temperature. Likewise, the solubility of cinnabar in solutions in the ternary system
$\mathrm{HgS}-\mathrm{Na}_{2} \mathrm{~S}-\mathrm{H}_{2} \mathrm{O}$ increases at an increasing rate as a function of temperature, and the rates are similar to those in the quaternary system.

The effects of temperature decrease in the range studied could be the precipitation of major fractions of the dissolved constituents. For example, in $0.1 \mathrm{~mol} / \mathrm{kg} \mathrm{Na}_{2} \mathrm{~S}$ solution saturated with both cinnabar and stibnite, a temperature decrease from $250^{\circ}$ to $150^{\circ} \mathrm{C}$ would cause the precipitation of about one-half of the dissolved $\mathrm{HgS}$ and about one-six th of the dissolved $\mathrm{Sb}_{2} \mathrm{~S}_{3}$.

\section{CHEMICAL DISCUSSION}

\section{Solution equilibria}

Cinnabar and stibnite solubilities in aqueous $\mathrm{Na}_{2} \mathrm{~S}$ solutions can be explained only by the formation of soluble complexes. The reaction of $\mathrm{HgS}$ with $\mathrm{S}^{2-}$ to form $\mathrm{HgS}_{2}{ }^{2-}$, a highly soluble complex anion, has been well established (Knox, 1906; Dickson and Tunell, 1958; Schwarzenbach and Widmer, 1.963; Cooney and Hall, 1966). Complexes of $\mathrm{HgS}_{\text {with }} \mathrm{HS}^{-}$and $\mathrm{H}_{2} \mathrm{~S}$ have been reported (Schwarzenbach and Widmer, 1.963; Barnes and others, 1967) but they are of little quantitative importance under the conditions of our experiments. Sb, in contrast to $\mathrm{Hg}$, forms complexes with several substances-mostly $\mathrm{OH}^{-}$, $\mathrm{S}^{2-}, \mathrm{HS}$, and $\mathrm{H}_{2} \mathrm{~S}$-in aqueous $\mathrm{Na}_{2} \mathrm{~S}$ solutions. Many different reactions have been proposed, but at present there is great difficulty in selecting among them (Sillén and Martell, 1964). Because the reaction of $\mathrm{Na}_{2} \mathrm{~S}$ with liquid $\mathrm{H}_{2} \mathrm{O}$ is fundamental to the reaction of cinnabar and stibnite with aqueous $\mathrm{Na}_{2} \mathrm{~S}$ solutions, it will be discussed first.

The reaction of $\mathrm{Na}_{2} \mathrm{~S}$ with $\mathrm{H}_{2} \mathrm{O}$ proceeds stepwise, as follows:

and

$$
\begin{aligned}
\mathrm{Na}_{2} \mathrm{~S} & =2 \mathrm{Na}^{+}+\mathrm{S}^{2-}, \\
\mathrm{S}^{2-}+\mathrm{H}_{2} \mathrm{O} & =\mathrm{HS}^{-}+\mathrm{OH}^{-}, \\
\mathrm{HS}^{-}+\mathrm{H}_{2} \mathrm{O} & =\mathrm{H}_{2} \mathrm{~S}+\mathrm{OH}^{-} .
\end{aligned}
$$

Under the conditions of our experiments, reaction 3 is of no importance, but reaction 2 , the hydrolysis reaction of $\mathrm{S}^{2-}$, is of major importance. The equilibrium constant for reaction 2 is written as $K_{h}=\left[\mathrm{HS}^{-}\right]\left[\mathrm{OH}^{-}\right] /\left[\mathrm{S}^{2-}\right]$, where $K_{h}$ symbolizes the hydrolysis constant of $\mathrm{S}^{2-}$, and the quantities enclosed in brackets denote the activities of the enclosed ions.

Other equilibria of particular interest are the ionization equilibrium of liquid $\mathrm{H}_{2} \mathrm{O}$ and the first and second ionization equilibria of $\mathrm{H}_{2} \mathrm{~S}$ in solution. The reactions with their corresponding equilibrium constants are as follows:

$$
\begin{array}{ll}
\mathrm{H}_{2} \mathrm{O}=\mathrm{H}^{+}+\mathrm{OH}^{-}, K_{w}=\left[\mathrm{H}^{+}\right]\left[\mathrm{OH}^{-}\right], \\
\text {and } \quad \mathrm{H}_{2} \mathrm{~S}=\mathrm{H}^{+}+\mathrm{HS}^{-}, K_{1}=\left[\mathrm{H}^{+}\right]\left[\mathrm{HS}^{-}\right] \\
\mathrm{HS}^{-}=\mathrm{H}^{+}+\mathrm{S}^{2-}, K_{2}=\left[\mathrm{H}^{+}\right]\left[\mathrm{S}^{2-}\right] /\left[\mathrm{HS}^{-}\right] .
\end{array}
$$

The hydrolysis constant of $\mathrm{S}^{2-}$ can be written in terms of $K_{w}$ and $K_{2}$ as follows:

$$
K_{h}=K_{w} / K_{2}=\left[\mathrm{HS}^{-}\right]\left[\mathrm{OH}^{-}\right] /\left[\mathrm{S}^{2-}\right] \text {. }
$$


The constant $K_{w}$ is well known as a function of temperature and pressure (Quist, 1970). It is about $10^{-14}$ at $25^{\circ} \mathrm{C}$ and 1 bar. However, $K_{2}$ values in the literature range from $10^{-11}$ to $10^{-17}$, and most workers have used values in. the range $10^{-13}$ to $10^{-15}$. Recent experimental studies by Ellis and Giggenbach (1971) suggest that $K_{2}$ at $25^{\circ} \mathrm{C}$ and 1 bar has a maximum value of $10^{-1} 7.2$ and that it may be even smaller.

The hydrolysis of $\mathrm{S}^{2-}$ in aqueous solutions is so extensive that for practical equilibrium calculations it should be considered complete. Substituting a $K_{2}$ value of $10^{-17}$ and a $K_{w}$ value of $10^{-14}$ in equation 7 , we calculate that $K_{h}=10^{3}$. The concentration of $\mathrm{S}^{2-}$ in a solution containing $1 \mathrm{~mol} / \mathrm{kg} \mathrm{Na}_{2} \mathrm{~S}$ would thus be only about $10^{-3} \mathrm{~mol} / \mathrm{kg}$. Therefore, in calculations of solution equilibria, $\mathrm{Na}_{2} \mathrm{~S}$ solutions are better considered as equiconcentration mixtures of $\mathrm{NaHS}$ and $\mathrm{NaOH}$. Reactions of metallic sulfide solutions with $\mathrm{Na}_{2} \mathrm{~S}$ solutions should be written in terms of $\mathrm{HS}^{-}$and $\mathrm{OH}^{-}$. For example, instead of writing the $\mathrm{HgS}$ reactions with $\mathrm{S}^{2-}$ in the conventional way, $\mathrm{HgS}+\mathrm{S}^{2-}=\mathrm{HgS}_{2}{ }^{2-}$, it should be written as $\mathrm{HgS}+\mathrm{HS}^{-}+\mathrm{OH}^{-}=\mathrm{HgS}_{2}{ }^{2-}+\mathrm{H}_{2} \mathrm{O}$.

\section{Reaction of stibnite with aqueous $\mathrm{Na}_{2} \mathrm{~S}$ solutions}

Many possibilities exist for the $\mathrm{Sb}$ complex species in $\mathrm{Na}_{2} \mathrm{~S}$ solutions that react with $\mathrm{Sb}_{2} \mathrm{~S}_{3}$. Sillén and Martell (1964) listed the postulated reaction products of $\mathrm{Sb}_{2} \mathrm{~S}_{3}$ with $\mathrm{HS}^{-}, \mathrm{S}^{2-}$ and $\mathrm{OH}^{-}$as follows: $\mathrm{HSb}_{2} \mathrm{~S}_{4}^{-}, \mathrm{SbS}_{3}{ }^{3-}, \mathrm{SbS}_{2}^{-}, \mathrm{Sb}_{4} \mathrm{~S}_{7}{ }^{2-}$, $\mathrm{SbO}_{3}{ }^{3-}$, and $\mathrm{SbS}(\mathrm{OH})_{2}{ }^{-}$. Complexes of $\mathrm{Sb}$ with $\mathrm{O}^{2-}$ and $\mathrm{OH}^{-}$ that exist in aqueous solutions which have reacted with $\mathrm{Sb}_{2} \mathrm{O}_{3}$, according to Sillén and Martell (1971), include $\mathrm{SbO}_{2}{ }^{-}$, $\mathrm{Sb}_{4} \mathrm{O}_{7}{ }^{2-}, \mathrm{Sb}_{6} \mathrm{O}_{10}{ }^{2-}, \mathrm{Sb}(\mathrm{OH})_{3}$, and $\mathrm{Sb}(\mathrm{OH})_{4}^{-}$. Shestitko and Demina (1971) proposed, on the basis of potentiometric studies of $\mathrm{Na}_{2} \mathrm{~S}$ solutions that have reacted with $\mathrm{Sb}_{2} \mathrm{~S}_{3}$, a series of complexes of the form $\mathrm{Sb}_{2} \mathrm{~S}_{3}^{2 n-n}$, in which $n$ may be $1 / 2,1,2,3$, or even larger. Arntson, Dickson, and Tunell (1966), on the basis of determinations of stibnite solubilities in aqueous $\mathrm{Na}_{2} \mathrm{~S}$ solutions, postulated the presence of $\mathrm{Sb}_{4} \mathrm{~S}_{7}{ }^{2-}$ as the dominant complex in the solutions. On the basis of thermochemical calculations, Brookins (1972) suggested that the complex $\mathrm{SbS}_{3}{ }^{3-}$, rather than $\mathrm{SbS}_{2}{ }^{2-}, \mathrm{HSbS}_{2}{ }^{-}$, or $\mathrm{Sb}_{4} \mathrm{~S}_{7}{ }^{2-}$, is important in the transport of $\mathrm{Sb}$ in aqueous solutions. At present, our knowledge of the complex ions containing $\mathrm{Sb}$ is in an incomplete state. However, it is known that stibnite reacts with $\mathrm{OH}^{-}$in the absence of $\mathrm{HS}^{-}$. Akeret (1953), cited by Sillén and Martell (1964), proposed the reactions, $1 / 2 \mathrm{Sb}_{2} \mathrm{~S}_{3}+30 \mathrm{H}^{-}$ $=1 / 2 \mathrm{SbS}_{3}{ }^{3-}+1 / 2 \mathrm{SbO}_{3}{ }^{3-}+3 / 2 \mathrm{H}_{2} \mathrm{O}$, with an equilibrium constant of $10^{4.015}$. Raab (1969) reported a high solubility of stibnite in $\mathrm{KOH}$ solutions at $25^{\circ} \mathrm{C}$ and $1 \mathrm{bar}$; although he did not propose a reaction, his data appear to be consistent with the reaction proposed by Akeret.

Raab's (1969) stibnite solubilities in $\mathrm{KOH}$ are about 30 percent lower than Arntson, Dickson, and Tunell's (1966) stibnite solubilities in $\mathrm{Na}_{2} \mathrm{~S}$ under equivalent conditions. Therefore, stibnite reacts in aqueous $\mathrm{Na}_{2} \mathrm{~S}$ solutions with both
$\mathrm{OH}^{-}$and $\mathrm{HS}^{-}$to produce a mix ture of complexes. Furthermore, the reaction with $\mathrm{OH}^{-}$has as much quantitative importance as the reaction with $\mathrm{HS}^{-}$. The nature of the reaction of stibnite with alkaline sulfide solutions can be clarified only by carefully designed experiments yet to be done.

\section{Temperature coefficient of stibnite solubility}

The solubility of stibnite in aqueous $\mathrm{Na}_{2} \mathrm{~S}$ solutions also saturated with cinnabar increases at an increasing rate with rising temperature according to the concave-upward curves of figure 3. A useful way to assess the effect of temperature is through the fractional temperature coefficient of solubility, defined as

$$
Q_{\mathrm{st}}=\frac{1}{c}\left(\frac{\partial c}{\partial T}\right)_{p, C}=\left(\frac{\partial \ln c}{\partial T}\right)_{\mathrm{Na}_{2} \mathrm{~S}}
$$

where $Q_{\text {st }}$ denotes the fractional temperature coefficient of stibnite solubility in ${ }^{\circ} \mathrm{C}^{-1}, c$ is the solubility of stibnite under one set of $T, p$, and $C_{\mathrm{Na}_{2} \mathrm{~S}}$ conditions, $\partial c / \partial T$ is the rate of change of stibnite solubility with temperature at that point, and $\ln c$ is the natural logarithm of the $\mathrm{Sb}_{2} \mathrm{~S}_{3}$ concentration. The advantage in using the fractional temperature coefficient over the conventional temperature. coefficient, $(\partial \mathrm{c} / \partial T)_{P, C_{\mathrm{Na}_{2} \mathrm{~S}}}$, is that comparisons can be made of the effect of temperature on solubilities of different solid phases in solutions of varying $\mathrm{Na}_{2} \mathrm{~S}$ concentrations.

The values of $Q_{\text {st }}$ were calculated from slopes of plots of $\ln c$ versus $T$, using smoothed data from the experimental studies. Only slight curvatures are exhibited by the $\ln c$ versus $T$ plots, and the approximation that they are linear seems justified in view of the experimental uncertainties: Galculated on this basis the mean $Q_{\text {st }}$ values, in ${ }^{\circ} \mathrm{C}^{-1}$ for the different $\mathrm{Na}_{2} \mathrm{~S}$ concentrations in moles per kilogram, are $1.3 \times 10^{-3}, 0.2270 \mathrm{Na}_{2} \mathrm{~S}$; $1.7 \times 10^{-3}, 0.110 \mathrm{Na}_{2} \mathrm{~S}$; and $2.0 \times 10^{-3}, 0.0492 \mathrm{Na}_{2} \mathrm{~S}$. A rough extrapolation to zero $\mathrm{Na}_{2} \mathrm{~S}$ yields a $Q_{\text {st }}$ value of $2.5 \times 10^{-3}{ }^{\circ} \mathrm{C}^{-1}$ at infinite dilution. The slight variation, of the $Q_{\text {st }}$ values with temperature, the definite variation with $\mathrm{Na}_{2} \mathrm{~S}$ concentration, and the absolute values are in reasonable agreement with Norton's (1964) results under the same conditions.

\section{Temperature coefficient of cinnabar solubility}

The solubility of cinnabar in solutions of the quaternary system increases at an increasing rate with rising temperature (fig. 4). The fractional temperature. coefficient of cinnabar solubility, $Q_{c}$, defined in the same way as the $Q_{\text {st }}$ varies as a function of both temperature and $\mathrm{Na}_{2} \mathrm{~S}$-concentration at low temperatures, but as a function of temperature only at higher temperatures. At $175^{\circ} \mathrm{C}$ the $Q_{c}$ values in ${ }^{\circ} \mathrm{C}^{-1}$ for the three concentrations of $\mathrm{Na}_{2} \mathrm{~S}$ in moles per kilograms are $4.3 \times 10^{-3}$, $0.2270 \mathrm{Na}_{2} \mathrm{~S} ; 3.8 \times 10^{-3}, 0.110 \mathrm{Na}_{2} \mathrm{~S}$; and $2.2 \times 10^{-3}, 0.0492$ $\mathrm{Na}_{2} \mathrm{~S}$. In contrast, at $225^{\circ} \mathrm{C}, Q_{c}$ is almost constant and is about $6.9 \times 10^{-3}{ }^{\circ} \mathrm{C}^{-1}$. 
Dickson's (1964) $Q_{c}$ values for cinnabar solubility in solutions of the ternary system $\mathrm{HgS}-\mathrm{Na}_{2} \mathrm{~S}-\mathrm{H}_{2} \mathrm{O}$ are, strictly speaking, not directly comparable to our $Q_{c}$ values because of the large extent to which stibnite dominated our reaction. The $Q_{c}$ values of Dickson $(1964)$, in ${ }^{\circ} \mathrm{C}^{-1}$, at $175^{\circ} \mathrm{C}$, are $1.8 \times 10^{-3}$, $0.286 \mathrm{Na}_{2} \mathrm{~S}$; and $0.84 \times 10^{-3}, 0.085 \mathrm{Na}_{2} \mathrm{~S}$. At $225^{\circ} \mathrm{C}$, they are $2.9 \times 10^{-3}, 0.286 \mathrm{Na}_{2} \mathrm{~S}$; and $1.6 \times 10^{-3}, 0.085 \mathrm{Na}_{2} \mathrm{~S}$. His $Q_{c}$ values vary with both temperature and $\mathrm{Na}_{2} \mathrm{~S}$ concentration, but they are smaller than our values, and they tend to vary less with temperature. They are, however, about the same order of magnitude and show similar trends. The gross agreement probably reflects a general tendency for solubilities of the sulfides of $\mathrm{Hg}, \mathrm{Sb}$, and $\mathrm{As}$ in $\mathrm{Na}_{2} \mathrm{~S}$ solutions to increase with rising temperature as a consequence of shifts of homogeneous equilibria among the hydrolysis products of $\mathrm{Na}_{2} \mathrm{~S}$ and changes in the ionization constants of $\mathrm{H}_{2} \mathrm{~S}$ and $\mathrm{H}_{2} \mathrm{O}$, as suggested by Dickson (1966).

\section{Reaction rates of stibnite and cinnabar with aqueous solutions}

Stibnite reacts very much more slowly with aqueous solutions than does cinnabar, and considerable experimental difficulties were encountered at temperatures below $150^{\circ} \mathrm{C}$. We found, for example, that 21 days were required to equilibrate stibnite with aqueous $\mathrm{Na}_{2} \mathrm{~S}$ solutions at $150^{\circ} \mathrm{C}$ and 100 bars in the presence of cinnabar. Experiments at $100^{\circ} \mathrm{C}$ were abandoned because the required reaction times were in terms of months.

Stibnite reacts slowly with other kinds of solutions. Raab (1969) found that 23 days were required to reach a steadystate concentration in aqueous $\mathrm{Na}_{2} \mathrm{~B}_{4} \mathrm{O}_{7}$ solution, which reacted with stibnite at $100^{\circ} \mathrm{C}$ and 100 bars, and that about 200 days were necessary for aqueous $\mathrm{KOH}$ solutions to reach equilibrium at $25^{\circ} \mathrm{C}$ and 1 bar with stibnite. Querol-Suñe (1974) has found that stibnite takes at least 30 days to equilibrate with simple $\mathrm{H}_{2} \mathrm{O}$ solution at $250^{\circ} \mathrm{C}$ and 500 bars. Therefore, it appears that stibnite shows a general tendency to react sluggishly, regardless of solution type.

Cinnabar and metacinnabar (black $\mathrm{HgS}$ ) react rapidly with aqueous $\mathrm{Na}_{2} \mathrm{~S}$ solutions; only a few hours are required for the attainment of equilibrium at $25^{\circ} \mathrm{C}$ and 1 bar (Dickson and Tunell, 1958). Obviously, in this respect $\mathrm{HgS}$ behaves very differently from $\mathrm{Sb}_{2} \mathrm{~S}_{3}$.

The slow reaction of stibnite with aqueous solutions of diverse types appears to be a consequence of the complicated nature of the dissolution reaction and the complexity of the Sb-containing ions in solution. Part of the kinetic hindrance may reflect the manner in which $\mathrm{Sb}$ atoms are bound to $\mathrm{S}$ atoms in the crystal structure of stibnite, which could influence the characteristics of $\mathrm{Sb}_{2} \mathrm{~S}_{3}$ groups as they initially enter the solution. According to Sćavničar (1960), stibnite is made up of polymeric $\left(\mathrm{Sb}_{2} \mathrm{~S}_{3}\right)_{n}$ ribbons, linked laterally to other ribbons by relatively weak $\mathrm{Sb}-\mathrm{S}$ bonds. Dissolution of stibnite probably entails breaking the weak bonds between ribbons and liberation of fragments of the $\left(\mathrm{Sb}_{2} \mathrm{~S}_{3}\right)_{n}$ ribbons which pass into solution. The reaction of the ribbon fragments with the several ions in solution in the adjustment to achieve equilibrium probably involves several steps. The probability is high that in what must be a complicated sequence one of the steps is slow and, therefore, rate determining.

The rapidity with which cinnabar reacts with aqueous $\mathrm{Na}_{2} \mathrm{~S}$ solution probably reflects the simplicity of the reaction. Only one $\mathrm{Hg}$-containing ion forms in solutions in the systems $\mathrm{HgS}-\mathrm{Na}_{2} \mathrm{~S}-\mathrm{H}_{2} \mathrm{O}$ and $\mathrm{HgS}-\mathrm{Sb}_{2} \mathrm{~S}_{3}-\mathrm{Na}_{2} \mathrm{~S}-\mathrm{H}_{2} \mathrm{O}$, the simple anion, $\mathrm{HgS}_{2}{ }^{2-}$, the existence of which is well documented (Knox, 1906; Dickson and Tunell, 1958; Cooney and Hall, 1966).

\section{CONCLUSIONS DRAWN FROM FIELD OBSERVATIONS AND LABORATORY EXPERIMENTS CONCERNING THE MODE OF ORIGIN OF CINNABAR, METACINNABAR, AND STIBNITE DEPOSITS}

Some of the reasons that have previously led to the conclusion that in the formation of cinnabar and metacinnabar deposits the HgS was transported to the sites of the deposits in liquid alkaline sulfide solutions are as follows. In almost all mercury ore deposits, cinnabar is the principal ore mineral, although in some deposits it is accompanied by considerable amounts of metacinnabar and (or) native mercury. Thus, the principal problem to be solved in the elucidation of the physicochemical processes that produced the ores is the determination of the kind of solution or kinds of solutions in which the large amounts of $\mathrm{HgS}$ present in the ore deposits were transported and from which they were precipitated. In numerous mercury ore deposits there has been much replacement of quartz, limestone, and dolomite by cinnabar. At Almadén, Spain, location of the most productive mercury mine in the world, Ransome (1921) and others have observed that much of the cinnabar replaced quartzite. In their comprehensive report on the geology and quicksilver deposits of the New Almaden district, California, Bailey and Everhart (1964) stated that the quicksilver ores of this district resulted mainly from the replacement of silica-carbonate rock by cinnabar, but also in minor part from replacement of other rocks and the filling of open space by cinnabar or quartzdolomite veins containing cinnabar. Bailey and Everhart concluded,

The fact that the ores were formed by replacement, a process that entailed the removal of large amounts of material as well as the deposition of cinnabar, indicates the presence of a liquid phase; and replacement by cinnabar just beneath the alta in structural domes indicates the absence of a vapor phase, which, if present, would fill the structural highs and keep out the ore-depositing liquid.

Similar arguments could be made regarding formation of many other cinnabar deposits; thus it seems clear that most cinnabar deposits were formed mainly by the action of aqueous solutions.

From geological evidence some limits can be set on the temperatures and pressures of the solutions that precipitated the cinnabar deposits. The deepest known mercury deposits, 
those at New Almaden, Calif., extend downward only about $792 \mathrm{~m}(2,600 \mathrm{ft})$ below the Earth's surface. The hydrostatic pressure at the base of a column of liquid water $792 \mathrm{~m}$ in depth is a little less than 80 bars. The boiling temperature of water at this pressure is about $280^{\circ} \mathrm{C}$. The inclusion of dissolved gases and salts would change this a little, but it seems reasonably certain that most mercury ores were deposited at temperatures less that $280^{\circ} \mathrm{C}$ and at pressures less than 80 bars. The fact that cinnabar is the principal ore mineral in almost all mercury ore deposits makes it necessary to suppose that the mercury and sulfur were brought to the sites of the deposits in the same solution; to assume that a soluble salt of mercury such as $\mathrm{HgCl}_{2}$ was transported to each of these sites in one solution and $\mathrm{H}_{2} \mathrm{~S}$ or $\mathrm{NaHS}$ or $\mathrm{Na}_{2} \mathrm{~S}$ was transported to each of these sites simultaneously in another solution, the mixing of the two solutions then causing the precipitation of the cinnabar, is too improbable. Thus we must ask what kind or kinds of liquid solutions at temperatures less than $280^{\circ} \mathrm{C}$ and pressures less than 80 bars were capable of carrying sufficient amounts of $\mathrm{HgS}$ in solution to make the large bodies of ore in the principal mercury mines, and what caused the precipitation of the cinnabar from the solution or solutions.

The solubility of $\mathrm{HgS}$ in water is among the lowest of all the metallic sulfides; Krauskopf (1951) reported the solubility at $25^{\circ} \mathrm{C}$ and 1 atm to be about $10^{-22} \mathrm{~mol} / \mathrm{l}$ of $\mathrm{HgS}$ or approximately $2 \times 10^{-17} \mathrm{p} / \mathrm{m}$. He calculated from this basis that to deposit 1 ton of $\mathrm{HgS}$ at least $10^{23} \mathrm{l}$ of liquid would have to pass through a vein fissure. A volume of $10^{23} \mathrm{l}$, he pointed out, is approximately 100 times the volume of water in all the oceans. The solubility of $\mathrm{HgS}$ in aqueous solutions of $\mathrm{CO}_{2}$ is slightly higher according to Krauskopf, but not sufficiently high to be of significance for an ore-forming solution. Hence it appears that if the mercury and sulfur of cinnabar deposits were transported in liquid solutions, these solutions must have contained other constituents besides $\mathrm{H}_{2} \mathrm{O}$ and $\mathrm{CO}_{2}$ that increased the solubility of $\mathrm{HgS}$. Krauskopf evaluated various other chemical mechanisms for the transportation of mercury in vcin fluids by calculations based on available thermodynamic data. He showed very clearly that chemically feasible mechanisms are transportation as $\mathrm{HgS}_{2}{ }^{2-}$ ions in alkaline sulfide solutions, as $\mathrm{HgCl}_{2}$ in a vapor phase and as the vapor of elemental mercury. He also showed that chemical mechanisms depending on the decrease of ionization or the decrease of solubility of $\mathrm{H}_{2} \mathrm{~S}$ at high temperatures, or on the elimination of $\mathrm{H}_{2} \mathrm{~S}$ at high temperatures by displacement of equilibrium in a gas phase, or on the formation of mercury-halogen complex ions are inadequate to account for the transportation of the quantities of mercury present in ore deposits without involving unreasonably large quantities of vein fluids. Since the chloride complexes are inadequate for the transportation of sufficient quantities of $\mathrm{Hg}$ in the presence of $\mathrm{S}$, and since other complex-forming elements are probably scarce in vein solutions, he concluded that no complex ion except $\mathrm{HgS}_{2}{ }^{2-}$ has probably played a role in the formation of mercury ores. More recently Barnes, Romberger, and Stemprok (1967) stated that in neutral to weakly alkaline solutions transport of mercuric sulfide may also have occurred as bisulfide complexes. They concluded that on the basis of present evidence the relative geological importance of bisulfide and sulfide complexes is uncertain. We agree with their conclusion as it pertains to small deposits, but for major deposits, such as Almadén and New Almaden, it appears probable that more alkaline and more concentrated solutions were involved in which the sulfide complex would have predominated.

The solubility of black $\mathrm{HgS}$ (metacinnabar) in acidic solutions and near-neutral and neutral solutions in which its solubility is very slight, as well as in alkaline solútions in which its solubility is appreciable, was investigated by Sćhwarzenbach and Widmer (1963). In one series of experiments they determined the solubility of black $\mathrm{HgS}$ at $20^{\circ} \mathrm{C}$ in aqueous solutions containing $0.0190 \mathrm{~mol} / \mathrm{l}$ (about $585 \mathrm{p} / \mathrm{m}$ ) of total $\mathrm{S}$, at $\mathrm{pH}$ values ranging from -0.05 to 10.74 , by the use of a radiometric method; the values of the solubility obtained by them, recalculated as parts per million of dissolved $\mathrm{HgS}$, are given in table 2. Schwarzenbach and Widmer stated that in

Table 2.-The solubility of black $\mathrm{HgS}$ as a function of $\mathrm{pH}$

[ $\mathrm{HgS}$ values are saturated concentrations at the given $\mathrm{pH}$ at $20^{\circ} \mathrm{C}$ in solutions in which the total $S$ concentration is $0.0190 \mathrm{~mol} / \mathrm{l}(585$ $\mathrm{p} / \mathrm{m}$ ) and the ionic strength is $1.00(\mathrm{KCl})$. The solubility values were recalculated in parts per million of $\mathrm{HgS}$ from the values of Schwarzenbach and Widmer (1962)]

\begin{tabular}{cc|cc}
\hline $\mathrm{pH}$ & $\begin{array}{c}\mathrm{HgS} \\
(\mathrm{p} / \mathrm{m})\end{array}$ & $\mathrm{pH}$ & $\begin{array}{c}\mathrm{HgS} \\
(\mathrm{p} / \mathrm{m})\end{array}$ \\
\cline { 1 - 2 } 1.00 & 0.005 & 8.23 & 0.044 \\
2.00 & .005 & 8.83 & .117 \\
4.57 & .005 & 9.70 & .68 \\
5.91 & .006 & 10.17 & 1.60 \\
6.84 & .014 & 10.38 & 2.44 \\
7.19 & .017 & 10.74 & 9.9 \\
\hline
\end{tabular}

saturated solutions having the same $\mathrm{pH}$, the concentration of dissolved $\mathrm{HgS}$ is approximately proportional to the total concentration of $\mathrm{S}$ in the form of $\mathrm{H}_{2} \mathrm{~S}$, in the form of $\mathrm{HS}$, and as $\mathrm{S}^{2-}$. Thus in the absence of dissolved $\mathrm{S}$ in the form of $\mathrm{H}_{2} \mathrm{~S}$ or HS or $\mathrm{S}^{2-}$ there could not be a geologically significant amount of $\mathrm{HgS}$ carried in solution. With as much as $585 \mathrm{p} / \mathrm{m}$ of dissolved $\mathrm{S}$ as $\mathrm{H}_{2} \mathrm{~S}$ and (or) $\mathrm{HS}^{-}$and (or) $\mathrm{S}^{2-}$, the amount of dissolved $\mathrm{HgS}$ in acid or neutral solutions does not exceed 0.02 $\mathrm{p} / \mathrm{m}$, which is insufficient in an ore solution for the formation of large mercury ore deposits without the passage of unreasonably large amounts of ore solution through the deposits. In slightly alkaline or moderately alkaline solutions of the same total $\mathrm{S}$ concentration, however, much larger amounts of $\mathrm{HgS}$ could be carried in solution, enough to account for the formation of the large ore bodies with the passage of conceivable amounts of ore solution. In a second series of experiments at various total concentrations of $\mathrm{S}$ at $20^{\circ} \mathrm{C}$, 
Schwarzenbach and Widmer determined the solubility of black $\mathrm{HgS}$ in solutions, the $\mathrm{pH}$ values of which ranged from 10.93 to 13.97; the concentration of dissolved $\mathrm{HgS}$ in these solutions ranged from 49 to $283 \mathrm{p} / \mathrm{m}$. The solubilities of black and red $\mathrm{HgS}$ in alkaline sulfide solutions at temperatures ranging from $25^{\circ}$ to $250^{\circ} \mathrm{C}$ have been determined over the range of dissolved $\mathrm{HgS}$ from $800 \mathrm{p} / \mathrm{m}$ ( 0.08 percent) to 20.7 percent by Dickson and Tunell (1958) and by Dickson (1964). The solubility of $\mathrm{HgS}$ in acidic, neutral, and alkaline sulfide solutions has thus been determined experimentally at low temperatures over the entire range of concentration of dissolved $\mathrm{HgS}$ from $0.005 \mathrm{p} / \mathrm{m}$ to 20.7 percent. The effects of changing temperature and changing pressure on the solubility of $\mathrm{HgS}$ in alkaline sulfide solutions were determined by Dickson and Tunell (1958) and by Dickson (1964). It was found that there is a slight decrease in solubility from $25^{\circ}$ to $100^{\circ} \mathrm{C}$ and a moderate increase in solubility with increase in temperature above $100^{\circ} \mathrm{C}$. The effect on the solubility of changing pressure in the range $1-100$ bars was found to be geologically negligible. The solubility of $\mathrm{HgS}$ in acid sulfide solutions at $20^{\circ} \mathrm{C}$, as determined by Schwarzenbach and Widmer, does not exceed $0.02 \mathrm{p} / \mathrm{m}$. According to Barnes, Romberger, and Stemprok (1967) the solubility of $\mathrm{HgS}$ in acid solutions increases much more with temperature than it does in alkaline solutions. However, they still concluded (p. 959, 980) that the solutions that transported the $\mathrm{HgS}$ to the sites of mercury ore deposits were probably neutral to alkaline.

The effects of additional constituents that are likely to have been present in the ore solutions have also been determined. The presence of chlorides, sulfates, borates, as well as the presence of $\mathrm{CO}_{2}$ does not increase the solubility of $\mathrm{HgS}$ significantly for geological purposes, if at all (Krauskopf, 1951; Dickson and Tunell, 1958; Raab, 1969). The presence of elemental $\mathrm{S}$ and the presence of $\mathrm{SiO}_{2}$ have been shown to decrease the solubility of $\mathrm{HgS}$ in alkaline sulfide solutions considerably (Knox, 1906; Learned, 1966). Finally it has been determined in the present investigation that the presence of $\mathrm{Sb}_{2} \mathrm{~S}_{3}$ reduces the solubility of $\mathrm{HgS}$ in alkaline sulfide solutions drastically. In summary, Krauskopf's conclusion that the most probable transporting agents of $\mathrm{HgS}$ are alkaline sulfide solutions appears well justified. Additional evidence supporting Krauskopf's conclusion is supplied by three groups of hot springs (Amedee Hot Springs, Lassen County, Calif.; Cedarville Hot Springs, Modoc County, Calif.; Boiling Springs, Valley County, Idaho) in which substantial quantities of cinnabar and metacinnabar have been deposited in recent times and are apparently still being deposited (Dickson and Tunell, 1968). The spring waters in these three groups of hot springs are all alkaline (their $\mathrm{pH}$ values ranging from 8.6 to 9.2) and all contain sulfide ion.

The constituents of stibnite can also be transported in substantial quantities in alkaline sulfide solutions although in addition they can be transported in geologically significant amounts in aqueous solutions containing compounds of boron, and even in water without other compounds (Norton, 1964; Raab, 1969; Dickson and Tunell, 1968).

The similarity in gross chemical characteristics of cinnabar and stibnite, particularly in respect to solubility behavior in aqueous $\mathrm{Na}_{2} \mathrm{~S}$ solutions, is in accord with the worldwide tendency for the two minerals to occur in the same ore districts in similar geologic environments. Both minerals are highly soluble in alkaline sulfide solutions, and both precipitate from such solutions as a result of the same physical and chemical changes in the solutions. The close association of cinnabar and stibnite in rocks strongly indicates a common mode of transport and deposition.

However, the tendency for cinnabar and stibnite not to occur in major amounts in the same deposits suggests that, in spite of the similarity in gross chemistry, some differences must exist in the details of the chemical behavior to account for the dispersion of the two minerals within districts.

In the present investigation it has been established that some of the important mineralogic relations observed in cinnabarstibnite mining districts can be explained on the basis of the solubility behavior of $\mathrm{HgS}$ and $\mathrm{Sb}_{2} \mathrm{~S}_{3}$ in alkaline sulfide solutions that are saturated with both cinnabar and stibnite. The observed tendency for cinnabar and stibnite to occur in separate deposits within the same mineral district can be explained on the basis that aqueous $\mathrm{Na}_{2} \mathrm{~S}$ solutions saturated with both cinnabar and stibnite carry much greater amounts of dissolved $\mathrm{Sb}_{2} \mathrm{~S}_{3}$ than $\mathrm{HgS}$. Major proportions of $\mathrm{HgS}$ could be carried only at times when the solutions are or become undersaturated with stibnite. The general tendency for cinnabar to be younger than stibnite in deposits where the two minerals occur together is thus understandable. Physical alterations in solution channelways between source locality and depositional site occurring during the mineralizing episode could then account for the observed spatial separation of cinnabar deposits from stibnite deposits within the same district.

Simultaneous deposition of appreciable amounts of cinnabar and stibnite from alkaline sulfide solutions requires certain specialized conditions. First, the transporting solutions must be undersaturated with stibnite to carry appreciable dissolved $\mathrm{HgS}$. In addition, simultaneous deposition of both minerals from such solutions could result only from nonequilibrium modes of precipitation. Thus the relatively uncommon occurrence of textures that indicate simultaneous deposition of cinnabar and stibnite would be expected from the solubility studies.

Regarding mechanisms of deposition of cinnabar and stibnite from alkaline sulfide solutions under conditions inferred for their environment of deposition, the following conclusions have been reached:

1. Temperature reductions encountered in the inferred environment of deposition would cause major fractions of 
dissolved $\mathrm{HgS}$ and $\mathrm{Sb}_{2} \mathrm{~S}_{3}$ to precipitate from alkaline sulfide solutions saturated with cinnabar and stibnite. For example, a saturated solution containing $0.1 \mathrm{~mol} / \mathrm{kg}$ of $\mathrm{Na}_{2} \mathrm{~S}$, cooled from $250^{\circ}$ to $150^{\circ} \mathrm{C}$ at 100 bars, would precipitate one-half of its original $\mathrm{HgS}$ content and about one-sixth of its initial $\mathrm{Sb}_{2} \mathrm{~S}_{3}$ content.

2. Dilution by meteoric waters of aqueous alkaline sulfide solutions saturated with both cinnabar and stibnite would cause the precipitation of major fractions of both dissolved constituents. The addition of one part of pure $\mathrm{H}_{2} \mathrm{O}$ to one part of a saturated solution containing 0.1 $\mathrm{mol} / \mathrm{kg}$ of $\mathrm{Na}_{2} \mathrm{~S}$ at $150^{\circ} \mathrm{C}$ and 100 bars would cause the precipitation of one-fourth of the $\mathrm{HgS}$ and one-fifth of the $\mathrm{Sb}_{2} \mathrm{~S}_{3}$.

3. Reaction of aqueous alkaline sulfide solutions containing dissolved $\mathrm{HgS}$ and $\mathrm{Sb}_{2} \mathrm{~S}_{3}$ with acid meteoric waters would serve as an effective mechanism of precipitation of both cinnabar and stibnite.

4. Reaction with quartz-bearing wallrocks would cause the precipitation of a major fraction of the $\mathrm{HgS}$ and part of the $\mathrm{Sb}_{2} \mathrm{~S}_{3}$. (See the experimental evidence of Learned, 1966.)

5. Oxidation of aqueous alkaline sulfide solutions containing dissolved $\mathrm{HgS}$ and $\mathrm{Sb}_{2} \mathrm{~S}_{3}$ would serve as an effective mechanism of precipitation of both sulfides. In the near-surface environment, the process would probably be complete within a short time.

\section{ACKNOWLEDGMENTS}

We acknowledge the financial support of the National Science Foundation. Our gratitude is also extended to the many mine owners who graciously permitted us to visit their properties. Paul Barton, U.S. Geological Survey, gave several valuable suggestions regarding presentation of the results of our study.

\section{REFERENCES CITED}

Akeret, Rudolf, 1953, Über die Löslichkeit von Antimon(3) Sulfid: Eidgenőssische Technische Hochschule Zürich, thesis, $77 \mathrm{p}$.

Arntson, R. H., Dickson, F. W., and Tunell, George, 1966, Stibnite $\left(\mathrm{Sb}_{2} \mathrm{~S}_{3}\right)$ solubility in sodium sulfide solutions: Science, v. 153, p. 1673-1674.

Bailey, E. H., and Everhart, D. L., 1964, Geology and quicksilver deposits of the New Almaden district, Santa Clara County, California: U.S. Geol. Survey Prof. Paper 360, 206 p.

Barnes, H. L., Romberger, S. B., and Stemprok, M., 1967, Ore solution chemistry II. Solubility of $\mathrm{HgS}$ in sulfide solutions: Econ. Geology, v. 62, p. 957-982.

Brookins, D. G., 1972, Stability of stibnite, metastibnite and some probable dissolved antimony species at $298: 15^{\circ} \mathrm{K}$ and 1 atmosphere: Econ. Geology, v. 67, p. 369-372.

Cooney, R. P. J., and Hall, J. R., 1966, Raman spectrum of thiomercurate(II) ion: Australian Jour. Chem. 19, p. 2179-2180.

Dickson, F. W., 1964, Solubility of cinnabar in $\mathrm{Na}_{2} \mathrm{~S}$ solutions at $50-250^{\circ} \mathrm{C}$ and $1-1,800$ bars with geologic applications: Econ. Geology, v. 59, p. 625-635.

1966, Solubilities of metallic sulfides and quartz in hydrothermal sulfide solutions: Bull. Volcanol., v. 29, p. 605-628.
Dickson, F. W., Blount, C. W., and Tunell, George, 1963, Use of hydrothermal solution equipment to determine the solubility of anhydrite in water from $100^{\circ} \mathrm{C}$ to $275^{\circ} \mathrm{C}$ and from 1 bar to 1,000 bars pressure: Am. Jour. Sci., v. 261, p. 61-78.

Dickson, F. W., and Tunell, George, 1958, Equilibria of 'red $\mathrm{HgS}$ (cinnabar) and black $\mathrm{HgS}$ (metacinnabar) and their saturated solutions in the systems $\mathrm{HgS}-\mathrm{Na}_{2} \mathrm{~S}-\mathrm{H}_{2} \mathrm{O}$ and $\mathrm{HgS-Na}{ }_{2} \mathrm{~S}-\mathrm{Na}_{2} \mathrm{O}-\mathrm{H}_{2} \mathrm{O}$ from $25^{\circ} \mathrm{C}$ to $75^{\circ} \mathrm{C}$ at 1 atmosphere pressure: Am. Jour. Sci., v. 256, p. 654,-679.

Dickson, F. W., and Tunell, George, 1968, Mercury and antimony deposits associated with active hot springs in the Western United States, in Ridge, J. D., ed., Ore deposits of the United States, 1933-1967: New York, Am. Inst. Mining, Metall. and Petroleum Engineers, p. 1673-1701.

Ellis, A. J., and Giggenbach, W., 1971, Hydrogen sulphide ionization and sulphur hydrolysis in high temperature solution: Geochim. et Cosmochim. Acta, v. 35, p. 247-260.

Fiala, R., and Konopik, N., 1950, Über das Dreistoffsystem $\mathrm{Na}_{2} \mathrm{~S}_{2} \mathrm{Sb}_{2} \mathrm{~S}_{3}-\mathrm{H}_{2} \mathrm{O}$ [Three-component system $\mathrm{Na}_{2} \mathrm{~S}_{-} \mathrm{Sb}_{2} \mathrm{~S}_{3}-\mathrm{H}_{2} \mathrm{O}$ ]: Monatshefte für Chemie, v. 81, p. 504-519.

Hiltner, W., and Gittel, W., 1935, Beiträge zur Systematik eines potentiometrischen Analysenganges, III Mitteilung-Die Abtrennung und Bestimmung von Hg: Zeitschr. Anal. Chemie, v. 101, p. 28-31.

Knox, J., 1906, Zur Kenntnis der Ionenbildung des Schwefels und der Komplexionen des Quecksilbers: Zeitschr. Electrochem, v. 12, p. $477-481$.

Krauskopf, K. B., 1951, Physical chemistry of quicksilver transportation in vein fluids: Econ. Geology, v. 46, p. 498-523.

Learned, R. E., 1966, The solubilities of quartz, quartz-cinnabar and cinnabar-stibnite in sodium sulfide solutions and their implications for ore genesis: Univ. California, $\mathrm{Ph}$. D. thesis, $175 \mathrm{p}$.

Norton, D. L., 1964, Geological and geochemical investigations of stibnite deposits: Univ. California, Ph. D. thesis, 116 p.

Querol-Suñe, F., 1974, The genesis of the antimony deposits at. Wadley, San Luis Potosi, Mexico-field investigations and stibnite solubility studies: Stanford Univ., Ph. D. thesis.

Quist, A. S., 1970, The ionization constant of water to $800^{\circ}$ and 4,000 bars: Jour. Phys. Chemistry, v. 74, p. 3396-3402.

Raab, W. J., 1969, Solubilities of stibnite, orpiment and realgar in borate, carbonate and hydroxide solutions as functions of temperature and pressure and their implications as applied to the borax deposit at Boron, California: Univ. California, Ph. D. thesis, 228 p.

Ransome, F. L., 1921, The ore of the Almaden mine: Econ. Geology, v. 16, p. 313-321.

Saukov, A. A., 1946, Geokhimiya rtuti [Geochemistry of mercury]: Akad. Nauk SSSR, Inst. Geol. Nauk Trudy, v. 78, Min.-Geokhim. Ser., No. 17, 129 p.

Ścavničar, S., 1960, The crystal structure of stibnite, in A redetermination of atomic positions: Zeitschr. Krist., v. 114, p. 85-97.

Schwarzenbach, G., and Widmer, Michael, 1963, Die Löslichkeit von Metallsulfiden I. Schwarzes Quecksilbersulfid: Helv. Chim. Acta. v. 46 , p. 2613-2628.

Shestitko, V. S., and Demina, O. P., 1971, Potentiometric determination of the composition of antimony sulfide complexes: Zhurn. Neorgan. Khimii, v. 16, no. 11, p. 3167-3168, 1679-1680; abs. in Chem. Abs., 1972, v. 76, no. 10 , abs. no. 50770r.

Sillén, L. G., and Martell, A. E., 1964, Stability constants of metal-ion complexes [2d ed.]: London, Burlington House, The Chem. Soc. Spec. Pub. 17, 754 p.

1971, Stability constants of metal-ion complexes, 2d ed., supp. no. 1: London, Burlington House, The Chem. Soc., Spec. Pub. 25, $885 \mathrm{p}$.

Smith, G. F., and May, R. L., 1941, Use of bromate in volumetric analysis, in Determination of arsenic and antimony with internal indicators at ordinary temperatures: Indus. Eng. Chemistry, Anal. Ed., v. 13, p. $460-461$. 


\title{
BIRNESSITE (DELTA $\mathrm{MnO}_{2} \cdot 3 \mathrm{H}_{2}$ O) IN A LARGE SPHERULITE IN OBSIDIAN NEAR SILVER CLIFF, COLORADO
}

\author{
By FRED A. HILDEBRAND, Denver, Colo.
}

\begin{abstract}
Birnessite and cryptomelane were identified in the montmorillonitic border zonc of a large spherulite in obsidian north of Silver Cliff, Colo. The manganese minerals contain no silver and probably formed more recently than argentian cryptomelane which is abundant in the manganiferous silver ores of the surrounding volcanic rocks.
\end{abstract}

Recent studies of manganiferous silver ores in rhyolitic rocks on the Silver Cliff Plateau (fig. 1) north of Silver Cliff, Custer County, Colo. have disclosed that the principal early-mined ore mineral was bromargyrite $(\mathrm{AgBr})$ that was accompanied by unrecognized silver-bearing cryptomelane which has now been given the varietal name argentian cryptomelane. The gangue minerals are mainly fluorite, barite, goethite, and dickite. The manganiferous silver ores are of the shallow, epithermal type

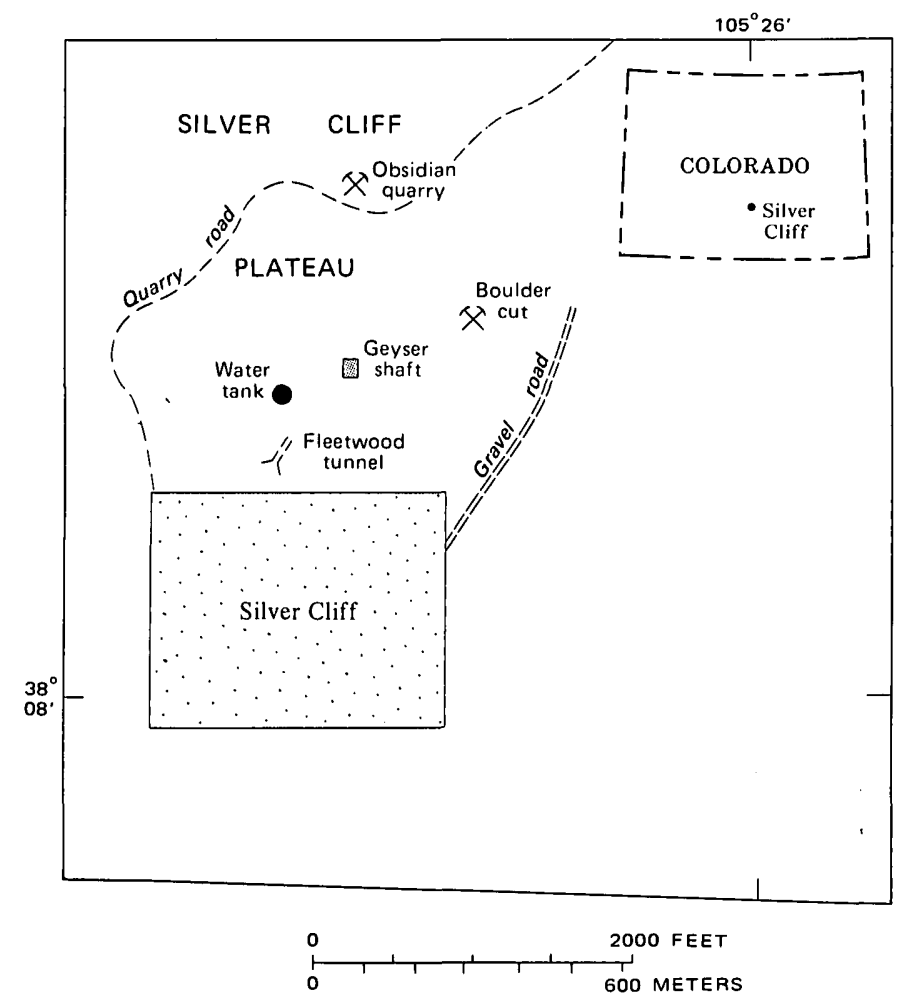

Figure 1.-Sketch map showing locations of workings on the Silver Cliff Plateau north of Silver Cliff, Colo.: Area is sec. 16, T. 22 S., R. 72 W. within a collapsed caldera. A hydrothermal origin is shown by the mineral assemblage, by vein wallrock alteration presumably at elevated temperature, and by relations of veins and ore minerals to subsidence faults.

This report describes an unusual occurrence of the manganese oxide mineral birnessite having the empirical formula (delta $\mathrm{MnO}_{2} \cdot 3 \mathrm{H}_{2} \mathrm{O}$ ) but containing minor amounts of calcium, sodium, potassium, and magnesium. At Silver Cliff, Colo., it is associated with cryptomelane $\left(\mathrm{KMn}_{8} \mathrm{O}_{16} \cdot \mathrm{H}_{2} \mathrm{O}\right)$ in montmorillonitic clay in the outermost part of a large devitrified spherulite in an obsidian layer. Unlike argentian cryptomelane in the manganiferous silver ores of the adjacent rhyolitic rocks, the two manganese minerals in the spherulite do not contain silver. Small amounts of non-silver-bearing todorokite and chalcophanite were also identified in the adjacent rhyolitic rocks by the author, but their mode of development and relative age have not been ascertained.

\section{SPHERULITIC OBSIDIAN}

Black obsidian on the Silver Cliff Plateau is interlayered with banded and massive rhyolitic flow rocks, flow breccias, and tuffs. These rocks were first described by Cross (1896). and later by Siems (1967). Both Cross and Siems showed that the obsidian is generally overlain by flow-banded rhyolite and underlain by rhyolitic breccias and tuffs. The obsidian is black, shiny, and glassy; has good conchoidal fracture; and in some places has altered to soft, smooth, white clay. It contains a few scattered sanidine crystals and, along some fractures, small amounts of purple fluorite. The obsidian has been impregnated in places by manganiferous silver ore minerals.

During the early mining period the obsidian layer was explored for silver ore as, for example, in the Flcetwood tunnel (fig. 1), abandoned since about 1890. Just inside the timbered portal the obsidian is altered to soft, white clay that is about 70 percent beidellite and 30 percent montmorillonite. This composition is notably different from that of the manganese-bearing spherulite described later. No manganese minerals of consequence were seen in the altered obsidian of the portal area.

Another early explored area is the Boulder cut (fig. 1) where Cross (1896, p. 298-299, 402-403) observed large spherulites greater than $10 \mathrm{ft}(3 \mathrm{~m})$ in diameter. Cross did not mention 
any manganiferous material in the Boulder cut, but he stated that spherulites in another working nearby contained "chloride ore," presumably bromargyrite, "psilomelane," presumably argentian cryptomelane, and "ocher," presumably goethite or dickite.

In the last decade several fresh exposures have been provided by new quarries to utilize the obsidian for terrazzo tile. One such new opening is the Obsidian quarry (fig. 1) which has in its north wall a large spherulite that contains the manganese minerals described in this report. Other small, scattered spherulites occur in the walls of the quarry but on the floor several large spherulites, possibly with diameters greater than $10 \mathrm{ft}(3 \mathrm{~m})$, are exposed with only their tops showing above the obsidian.

\section{MANGANESE-BEARING SPHERULITE}

The large spherulite on the north wall of the Obsidian quarry has been about one-half mined and is surrounded on the wall face by black glassy obsidian. The remaining half is about $7 \mathrm{ft}$ $(2 \mathrm{~m})$ in diameter, and its top is $2 \mathrm{ft}(2 / 3 \mathrm{~m})$ below the grass-covered surface. The central part has a coarse, radialfibrous structure and is composed mainly of pinkish-white feldspar and white clay; along fractures it contains some opaline silica. It is also speckled with insignificant amounts of impure manganiferous material as tiny blebs and very small veinlets. Away from the center the spherulite is less feldspathic and more clayey, and it contains a few scattered sanidine crystals and sparse patches of manganiferous material. The outermost $1 / 2$ - to $1-\mathrm{ft}$-wide $(15-30 \mathrm{~cm})$ zone is composed of white clay with small amounts of glass, manganese oxides, and beta cristobalite. The clay is dioctahedral montmorillonite of the three-layer water type. There is no associated beidellite as in the clay of the Fleetwood tunnel mentioned previously. Partial analysis (by the six-step semiquantitative spectrographic method), by Nancy Conklin of the U.S. Geological Survey, disclosed that the montmorillonite contains 3 percent $\mathrm{Ca}, 0.3$ percent $\mathrm{Na}, 5$ percent $\mathrm{Mg}$, and no detectable $\mathrm{K}$. Thin sections show that alteration of glass to montmorillonite has taken place along fractures and perlitic cracks and that islanded areas of glass remain in the montmorillonite. The manganese oxides were introduced later as evidenced by boxworks of veinlets in both montmorillonite and relict glass and also by fillings around fragments in brecciated areas. Some montmorillonite is pale pink and thus may contain manganese. The pink color may also be attributable to epistilbite, which was tentatively identified in a sample of the pinkest clay.

\section{BIRNESSITE AND CRYPTOMELANE}

In the border zone of the spherulite, birnessite and cryptomelane are in close association in nodular masses of irregular shape having a maximum dimension of about three-fourths inch. The cryptomelane is black, and dull to shiny, and in a very few open places, where it formed around or in perlitic structures, it is finely botryoidal. The birnessite is dark reddish-brown, very soft, and has a satiny luster. Like cryptomelane it also fills in around and occupies some perlitic structures. No differences in age between cryptomelane and birnessite were observed, and, apparently, they formed contemporaneously. Because of their intimate association with each other and with small amounts of montmorillonite, glass, and beta cristobalite, separation of the two minerals appeared impossible.

Spectrographic analysis of a mixture of mainly birnessite and cryptomelane disclosed that neither one is silver bearing. Birnessites have been reported to contain varying small amounts of calcium, sodium, potassium, and magnesium, but the compositions are considered uncertain because of difficulty in obtaining the pure mineral. Apparently, at other localities, as at Silver Cliff, birnessite is finely intermixed with other minerals. Occurrences of calcium-, sodium-, and potassium-rich birnessite have been reported and were summarized by Levinson (1962, p. 791), but no magnesium-rich variety has been reported. These elements are thought to balance charge deficiencies caused by $\mathrm{Mn}^{+2}$ substitution for $\mathrm{Mn}^{+4}$. A Silver Cliff mixture that was mainly birnessite with small amounts of cryptomelane and montmorillonite was found by spectrographic analysis to contain 3 percent Ca. Neither the cryptomelane nor montmorillonite impurities in this sample could account for this much calcium and, thus, most of the calcium content is attributable to the birnessite. Therefore, it is mainly a calcium birnessite.

$\mathrm{X}$-ray studies show that cryptomelane in the spherulite is poorly crystalline but that the birnessite has moderately good crystallinity comparable to that of previously reported occurrences. Birnessite has a diagnostic X-ray diffraction pattern with four broad and diffuse interplanar spacings (Jones and Milne, 1956, p. 284; Levinson, 1962, p. 791). The X-ray pattern of the Silver Cliff birnessite is identical with that of birnessite identified by the author in early 1965 in black calcite from Hamilton, Nev., where, as at Silver Cliff, birnessite is associated with cryptomelane, todorokite, and chalcophanite. Table 1 shows X-ray powder data for birnessites from Silver Cliff, Colo., Hamilton, Nev., and Birness, Scotland, the type locality.

\section{ORIGIN}

Delta $\mathrm{MnO}_{2}$ (artificial birnessite) has been synthesized in alkaline solution, and those published reports of naturally occurring birnessites that discuss the origin indicate that birnessite probably forms at earth temperatures in an alkaline environment by oxidation of manganous ions transported in solution to a zone of higher Eh and $\mathrm{pH}$. Apparently, it forms at low or high $\mathrm{pH}$ and at a lower redox potential as the $\mathrm{pH}$ increases (Krauskopf, 1967, p. 265). Birnessite cannot form in a hydrothermal environment, apparently because it easily converts to cryptomelane when heated (Jones and Milne, 1956, p. 287). 
Table 1.-X-ray diffraction data for birnessite

\begin{tabular}{lllrlr}
\hline \multicolumn{1}{c}{ Scotland $^{\prime}$} & \multicolumn{2}{c}{ Nevada $^{2}$} & \multicolumn{2}{c}{ Colorado $^{3}$} \\
\hline$d_{\text {hkl }}(\mathrm{A})$ & $I$ & $d_{\mathrm{hkl}}(\mathrm{A})$ & $I$ & $d_{\mathrm{hkl}}(\mathrm{A})$ & $I$ \\
\hline & & & & & \\
7.27 & $\mathrm{~S}$ & 7.4 & 100 & 7.4 & 100 \\
3.60 & $\mathrm{w}$ & 3.71 & 30 & 3.72 & 30 \\
2.44 & $\mathrm{~m}$ & 2.45 & 25 & 2.46 & 30 \\
1.41 .2 & $\mathrm{~m}$ & 1.424 & 25 & 1.421 & 20 \\
\hline
\end{tabular}

'Birness, Scotland (Jones and Milne, 1956, p. 285). Jones and Milne did not define the intensities. Presumably S, strong; $w$, weak; and $\mathrm{m}$, medium or moderate.

${ }^{2}$ Treasure Hill, Hamilton, Nev., (this report). Sample from Garland B. Gott and J. Howard McCarthy, Jr., 1964.

${ }^{3}$ Silver Cliff, Colo., Obsidian quarry (fig. 1). Collected 1971.

The author postulates that the birnessite and cryptomelane in the outer clayey margin of the spherulite formed recently and at or near the present surface when a weak acidic solution containing manganous ions, possibly acquired from ferroan rhodochrosite, penetrated the spherulite and was oxidized in the alkaline environment of the montmorillonitic clay and glass where calcuim, sodium, magnesium, and potassium were available. Ferroan rhodochrosite was identified during this study in a core specimen of white breccia from less than $90 \mathrm{ft}$ $(27 \mathrm{~m})$ deep beneath obsidian about $1,000 \mathrm{ft}(300 \mathrm{~m})$ northeast of the Obsidian quarry. It was also identified in other cores from nearby holes and there is evidence that it existed in the flow rhyolites above the obsidian layer as shown in outcrops and quarries by pseudomorphs of goethite and cryptomelane after a rhombohedral mineral and rosette clusters of rhombs, identical in size and shape with fresh rhodochrosite in the cores. The lack of silver in the manganese minerals of the spherulite implies that silver either was unavailable at the source or was not soluble in the cold solutions that transported the manganous ions into the spherulite.

This postulated mode of origin helps explain why birnessite and cryptomelane are most abundant in the outer zone of the spherulite and also why birnessite apparently does not occur in the manganiferous silver ores of probably hydrothermal origin in the nonglassy and nonclayey rhyolitic rocks.

\section{REFERENCES CITED}

Cross, Whitman, 1896, Geology of Silver Cliff and the Rosita Hills, Colorado: U.S. Geol. Survey 17th Ann. Rept., pt. 2, p. 263-403.

Jones, L. H. P., and Milne, A. A., 1956, Birnessite, a new manganese oxide mineral from Aberdeenshire, Scotland: Mineralog. Mag., v. 31, no. 235 , p. $283-288$.

Krauskopf, K. B, 1967, Introduction to geochemistry: New York, McGraw-Hill Book Co., 721 p.

Levinson, A. A., 1962, Birnessite from Mexico: Am. Mineralogist, v. 47, nos. 5 and 6, p. $790-791$.

Siems, P. L., 1967, Volcanic and economic geology of the Rosita Hills and Silver Cliff districts, Custer County, Colorado: Colorado School Mines, D. Sc. thesis, 222 p. 



\title{
MINERALOGICAL STUDIES OF THE NITRATE DEPOSITS OF CHILE IV. BRÜGGENITE, $\mathrm{Ca}\left(\mathrm{IO}_{3}\right)_{2} \cdot \mathrm{H}_{2} \mathrm{O}$, A NEW SALINE MINERAL
}

\author{
By GEORGE E. ERICKSEN, MARY E. MROSE, and JOHN W. MARINENKO, \\ Washington, D.C.
}

\begin{abstract}
Brüggenite, $\mathrm{Ca}\left(\mathrm{IO}_{3}\right)_{2} \cdot \mathrm{H}_{2} \mathrm{O}$, is found in veins of high-purity soda niter in rhyolite tuff at Pampa Pique III, Oficina Lautaro, Chile, as long columnar anhedral crystals, as prismatic crystals, and as irregular anhedral crystals or encrusting masses. The mineral is colorless to bright yellow, and transparent to translucent, has vitreous luster and a hardness of about $3 \frac{1}{2}$, is brittle, and has conchoidal fracture. It is biaxial and has variable optic angle and refractive indices, which were determined by the spindle-stage method. Refractive indices are as follows: $n_{\alpha}=1.772-1.779, n_{\beta}=1.795-1.802$, and $n_{\gamma}=1.817-1.824$ (all \pm 0.003$)$; optic angle shows a range of $2 V_{Z}=86^{\circ}-96^{\circ} ; Z=b$ and $X \wedge c=-47^{\circ}$; dispersion $(Z)$ is $r<v$, moderate. Brüggenite is monoclinic, space group $P 2_{1} / c$, with $a=8.509 \pm 0.001 \mathrm{~A}, b=10.027 \pm 0.002 \mathrm{~A}, c=7.512 \pm 0.001 \mathrm{~A}$, $\beta=95^{\circ} 16.00^{\prime} \pm 0.55^{\prime}$, volume $638.2 \mathrm{~A}^{3}, \mathrm{Z}=4, \mathrm{G}_{(\mathrm{calc})}=4.244$, $\mathrm{G}_{\text {(meas) }}=4.24 \pm 0.01$. The $\mathrm{X}$-ray diffraction powder pattern of brüggenite has the following strong lines $\left(h k l, d_{h k l} I\right): 031,3.051 \mathrm{~A}(100)$; $220,3.238$ A (90); 200, 4.235 A (80); 002, 3.739 A (60); $012,3.503$ A $(60) ; \overline{2} 31,2.522$ A $(60)$. The composition was confirmed by chemical analyses.
\end{abstract}

The new mineral brüggenite (pronounced brú-gĕn-aìt) was discovered in a suite of saline minerals from nitrate deposits at Pampa Pique III, about a kilometer north of Oficina Lautaro (fig. 1) in the Taltal nitrate district of Chile. The material was collected in 1965 by Ericksen and his Chilean colleagues Fernando Munizaga and Mauricio Tabak of the Instituto de Investigaciones Geológicas. This area is the type locality for the minerals lautarite, $\mathrm{Ca}\left(\mathrm{IO}_{3}\right)_{2}$, and dietzeite, $\mathrm{Ca}_{2}\left(\mathrm{IO}_{3}\right)_{2}\left(\mathrm{CrO}_{4}\right)$. Specimens of brüggenite, which range from colorless to bright yellow, were first assumed to be lautarite and dietzeite, but X-ray powder diffraction studies showed them to be a distinct mineral species. Identification of the new mineral was made somewhat more difficult than usual because the published powder data for lautarite are actually those of brüggenite, $\mathrm{Ca}\left(\mathrm{IO}_{3}\right)_{2} \cdot \mathrm{H}_{2} \mathrm{O}$.

Pampa Pique III is a nitrate mine area that formerly supplied ore for treatment at the nearby nitrate plant at Oficina Lautaro. The area is within a closed depression, several hundred meters in diameter and 10-20 m deep, in a terrain of reddish to purplish rhyolite ash-flow tuff. This depression is one of several in this part of the Taltal district and may be an original feature dating from the time the tuff was deposited,

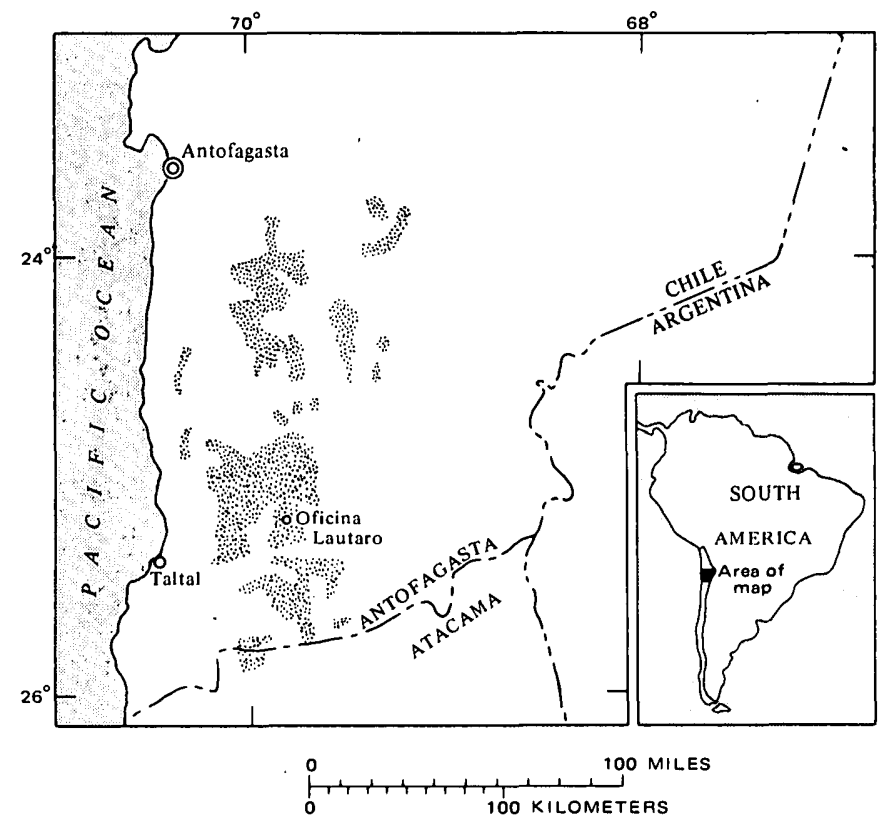

Figure 1.-Index map showing location of nitrate fields (stippled) in southern Antofagasta Province, Chile.

probably during the Pleistocene. However, the depression has been modified by wind deflation, the chief agent of erosion in this extremely dry region. Specimens for our study came from piles of nitrate ore and from veins in the tuff in the vicinity of a water well (Pique III) near the center and lowest part of the depression.

The veins (fig. 2) contain extremely high-purity soda niter; chemical analysis of a sample of fibrous nitrate from this locality showed it to contain 99.8 percent $\mathrm{NaNO}_{3}$ (Ericksen and Mrose, 1972, p. B48). Furthermore, the surface-leached zone of the veins is very shallow, commonly only 10 or $20 \mathrm{~cm}$ deep, in contrast with other areas where the leached zone is generally more than a meter deep.

The mineral is named for Juan Brüggen M. (1887-1953), a leader in the study of Chilean geology. As a professor at the University of Chile he trained many of the Chilean geologists and mining engineers who are the leaders in the present mining 


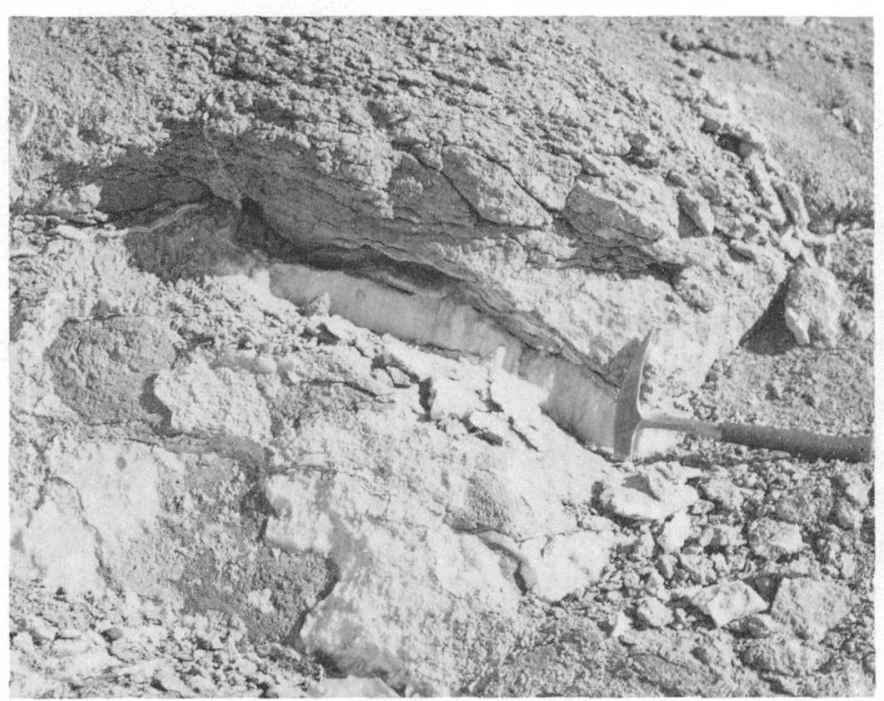

Figure 2.-Vein of fibrous to columnar soda niter, Pampa Pique III, Oficina Lautaro, Chile.

industry of Chile. His extensive bibliography covers many phases of Chilean geology and includes the first textbook on the geology of Chile. His descriptions of the nitrate deposits are among the most accurate that have been published.

The description and name of this new mineral were approved, in advance of publication, by the Commission on New Minerals and Mineral Names, I.M.A. A brief preliminary description of brüggenite appeared in an abstract (Mrose and others, 1971). Specimens of type material have been deposited in the mineral collection in the U.S. National Museum, Washington, D.C.; these consist of several small hand specimens, plus a vial containing approximately $10 \mathrm{~g}$ of purified crystalline material (USNM 122445).

\section{OCCURRENCE AND ORIGIN}

The brüggenite at Pampa Pique III occurs as thin columnar intergrowths in soda niter veins (fig. 2), as short subhedral prismatic crystals and encrusting masses, chiefly at margins of these veins, and as clusters of radiating prismatic crystals and impregnations in soft decomposed rhyolite tuff and gouge in the veins and the enclosing wall rock. The most spectacular specimens are those in which bright yellow brüggenite is intergrown with white fibrous to columnar soda niter that forms veins as much as $30 \mathrm{~cm}$ thick. The brüggenite in such veins occurs only in local patches that range from less than a centimeter to as much as $10 \mathrm{~cm}$ in longest dimension. Brüggenite may make up 50 percent or more of such patches. The thin columns of brüggenite are generally less than a millimeter across and less than $2 \mathrm{~cm}$ long. More rarely, the columns are as much as $5 \mathrm{~cm}$ long. Prismatic crystals occur as unterminated prisms as much as $1 \mathrm{~cm}$ long, showing a diamond-shaped cross section (fig. 3) as much as $6 \mathrm{~mm}$ in

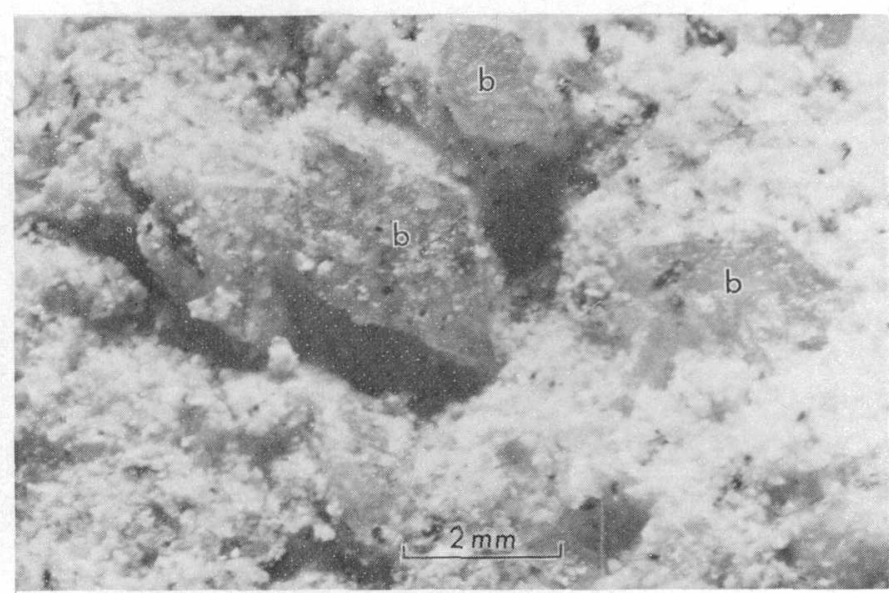

Figure 3.--Prismatic crystals of brüggenite (b) embedded in granular white soda niter, Pampa Pique III, Oficina Lautaro, Chile. Largest crystal shows diamond-shaped cross section about $4 \mathrm{~mm}$ in the longest dimension.

longest dimension. They are either partly intergrown in clusters or are individual crystals in the granular soda niter or saline-cemented decomposed rhyolite at the vein boundary.

Other saline minerals associated with the brüggenite at Pampa Pique III are anhydrite, $\mathrm{CaSO}_{4}$, lautarite, $\mathrm{Ca}\left(\mathrm{IO}_{3}\right)_{2}$, hydroboracite, $\mathrm{CaMgB}_{6} \mathrm{O}_{11} \cdot 6 \mathrm{H}_{2} \mathrm{O}$, and halite, $\mathrm{NaCl}$. Dietzeite was not found in our specimens, although Pampa Pique III is the type locality for this mineral (Osann, 1894, p. 588); we did identify it in specimens from this locality in the study collection of the U.S. National Museum, Washington, D.C. Anhydrite and halite are fairly abundant, lautarite is evidently less abundant than brüggenite, and hydroboracite is rare.

The brüggenite was deposited during at least two stages, first as an intergrowth with fibrous to columnar soda niter in veins and then in cavities at vein boundaries. The anhydrite formed earlier than the brüggenite and soda niter. Hydroboracite occurs in cavities in soda niter and therefore is younger than part of the brüggenite. Some of the crystalline lautarite and brüggenite are intimately associated, probably because of simultaneous crystallization of the two phases (see fig. 5) or partial alteration of one phase to the other after primary crystallization.

The source of the iodate is part of the broader problem of the origin of the nitrate desposits of Chile, a topic beyond the scope of this paper. Nevertheless, the association of abundant iodate minerals with the rhyolite tuffs of this region is unique and may indicate a genetic relation. The nitrate and the iodate minerals might have been deposited by thermal waters during the final phase of volcanic activity. Later, they might have migrated because of slow leaching by infrequent rains and might have been redeposited in veins lower in the depression. Alternatively, the iodine might have been supplied by atmospheric fallout, the ocean being the primary source. 


\section{PHYSICAL AND OPTICAL PROPERTIES}

Individual crystals of brüggenite are colorless to bright yellow, transparent to translucent, and have a vitreous luster. The bright yellow of some brüggenite may be due to trace amounts of chromate $\left(\mathrm{CrO}_{4}^{-2}\right)$ as impurity, but small fragments and crystals of brüggenite that appear colorless are very pale yellow when grouped together, suggesting that the color is an inherent property of the mineral; synthetic crystals of brüggenite are also pale ycllow. The powder and streak are white.

Brüggenite is brittle, has a hardness of $3 \frac{1}{2}$, lacks cleavage, and has conchoidal fracture. It does not fluoresce in either long- or short-wave ultraviolet light. The specific gravity, determined at $22^{\circ} \mathrm{C}$ on crystal fragments on the Berman microbalance, using toluene as the immersion liquid, is $4.24 \pm 0.01$ (an average of six determinations), in excellent agreement with the value $4.24 \pm 0.01$, determined by the pycnometer method at $25^{\circ} \mathrm{C}$, for synthetic brüggenite; the density calculated for brüggenite from the $\mathrm{X}$-ray data is 4.244 $\mathrm{g} \mathrm{cm}^{-3}$.

In transmitted light, brüggenite is colorless to very pale yellow and is nonpleochroic. The mineral is monoclinic, and synthetic prismatic crystals show orientation of $\mathrm{X} \wedge c=-47^{\circ}$, $\mathrm{Z}=b$. The previously reported orientation (Mrose and others, 1971) is in error because determinations were made on natural columnar material that later proved not to have true crystal forms. Dispersion ( $\mathrm{Z}$ ) is $r<v$, moderate.

The optic angle and refractive indices of both natural and synthetic brüggenite show considerable variation from grain to grain in apparently homogeneous material and even on different parts of a single grain or euhedral crystal (Ray E. Wilcox, written commun., 1973). Determinations of refractive indices were made on the spindle stage, using the focal masking technique, and by normal immersion method, using both sodium light and white light. Index oils were checked with a Leitz-Jelley-type microrefractometer at the times indices were measured. Optic angles were also measured on the spindle stage. Refractive indices for natural and synthetic brüggenite thus obtained are as follows: $n_{\alpha}=1.772-1.779$, $n_{\beta}=1.795-1.802$, and $n_{\gamma}=1.817-1.824$ (all measurements accurate to \pm 0.003$)$; the optic angle shows a range of $2 V_{\mathrm{z}}=86^{\circ}-96^{\circ}$. Twinning was not observed, although the columnar brüggenite that is intergrown with fibrous soda niter shows impressions of longitudinal twinning striae of crystals of the enclosing soda niter.

\section{CRYSTALLOGRAPHY}

Single-crystal X-ray data. -The unit-cell parameters of brüggenite from Pampa Pique III were first derived using Buerger precession techniques. Monoclinic cell constants and space group were obtained, using both nickel-filtered copper radiation and zirconium-filtered molybdenum radiation, with exposure times of approximately $72 \mathrm{~h}$ for the latter. The $0 \mathrm{kl}$,

$\mid k l ; 2 k l, h 0 l, h 2 l$, and $h 3 l$ reciprocal lattice nets were photographed. The conditions limiting the possible reflections are $h 0 l: l=2 n$ and $0 k 0: k=2 n$, so that the space group $P 2_{1} / c$ is thus uniquely defined. The cell data for the natural material, obtained by single-crystal techniques, are compared below with those derived from the X-ray diffraction powder data (table 1) by the least-squares refinement technique, using the digital computer program of Appleman and Evans (1973):

Single-crystal data
(precession melhod)

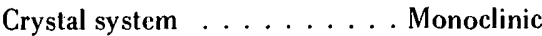

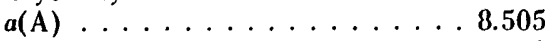

$b(\mathrm{~A}) \ldots \ldots \ldots \ldots \ldots \ldots$

$c(\mathrm{~A}) \ldots \ldots \ldots \ldots \ldots \ldots \ldots$

$\beta \ldots \ldots \ldots \ldots 5^{\circ} 20^{\prime} \pm 10^{\prime}$

$a: b: c \ldots \ldots \ldots . \ldots 0.8505: 1: 0.7498$

Space group ........., $P 2_{1} / c$

Cell volume .......... . . 634.9 $\mathrm{A}^{3}$

Cell contents ..... $4\left[\mathrm{Ca}\left(\mathrm{IO}_{3}\right)_{2} \cdot \mathrm{H}_{2} \mathrm{O}\right]$

Density (calc) ..... $4.267 \mathrm{~g} \mathrm{~cm}^{-3}$

$X$-ray powder data.-X-ray powder patterns were prepared for brüggenite from Pampa Pique III and for crystals of: $\mathrm{Ca}\left(\mathrm{IO}_{3}\right)_{2} \cdot \mathrm{H}_{2} \mathrm{O}$ synthesized during this study; the powder patterns of both are identical. Indexed X-ray powder data for brüggenite are listed in table 1 . The powder data cited in the Powder Diffraction File (formerly ASTM) card 1-0386 for so-called synthetic lautarite ( = synthetic brüggenite) are compared in table 1 with those of brüggenite of this study.

Morphology.-Most brüggenite occurs as anhedral crystals or cryptocrystalline masses. The anhedral crystals are long, thin, and columnar, elongated $c$, and are intergrown with fibrous to columnar soda niter crystals; these brüggenite crystals tend to have irregular rough striated faces that reflect the growth pattern of the soda niter. Faces on these crystals, limited to the prism zone, are distorted. Some may be true crystal faces; others clearly are not.

Prismatic crystals of brïggenite are as much as a centimeter long in the $c$ direction and show a diamond-shaped cross section, as much as $6 \mathrm{~mm}$ long in the $b$ direction (fig. 3). Interfacial angles measured with a petrographic microscope gave a phi angle of $60^{\circ}$ for several of the diamond-shaped cross sections, which compares favorably with a calculated phi of $60^{\circ} 36^{\prime}$ for the prism form $\{320\}$. None of the many synthetic crystals examined in the course of this study showed this form.

Four small, terminated, apparently euhedral crystals of natural brüggenite, of long prismatic habit (length:width: thickness, approximately $0.5 \mathrm{~mm}: 0.15 \mathrm{~mm}: 0.10 \mathrm{~mm}$ ) were measured on the optical goniometer. The interfacial angles obtained for the four $h k 0$ faces in the prism zone were not consistent with those of a prism form; these faces undoubtedly resulted from growth control effected by the fibrous soda niter. Forms observed on these crystals were $b\{01.0\}$, as very narrow faces, and the clinodome, $w\{011\}$. 
Table 1. $-X$-ray diffraction powder data for brüggenite, $\mathrm{Ca}\left(\mathrm{IO}_{3}\right)_{2} \cdot \mathrm{H}_{2} \mathrm{O}$

[Monoclinic, $P 2_{1} / c: a=8.509 \pm 0.001 \mathrm{~A}, b=10.027 \pm 0.002 \mathrm{~A}, c=7.512 \pm 0.001 \mathrm{~A}, \beta=95^{\circ} 16.00^{\prime} \pm 0.55^{\prime}$ ]

\begin{tabular}{|c|c|c|c|c|c|c|c|c|c|c|c|}
\hline \multicolumn{4}{|c|}{ Pampa Pique III, Oficina Lautaro, Chile } & \multirow{2}{*}{\multicolumn{2}{|c|}{$\begin{array}{l}\text { "Lautarite" (PDF 1-0386) } \\
=\text { synthetic brüggenite } \\
\text { Measured }^{3}\end{array}$}} & \multicolumn{4}{|c|}{ Pampa Pique III, Oficina Lautaro, Chile } & \multirow{2}{*}{\multicolumn{2}{|c|}{$\begin{array}{l}\text { "Lautarite" (PDF 1-0386) } \\
=\text { synthetic brüggenite } \\
\text { Measured }^{3}\end{array}$}} \\
\hline \multirow{2}{*}{$h k l$} & \multirow{2}{*}{$\frac{\text { Calculated }^{1}}{d(\mathrm{~A})}$} & \multicolumn{2}{|c|}{ Measured $^{2}$} & & & \multirow{2}{*}{$h k l$} & \multirow{2}{*}{$\frac{\text { Calculated }^{1}}{d(\mathrm{~A})}$} & \multicolumn{2}{|c|}{ Measured $^{2}$} & & \\
\hline & & $d(\mathrm{~A})$ & $\overline{I^{4}}$ & $d(\mathrm{~A})$ & $\bar{I}$ & & & $d(\mathrm{~A})$ & $\overline{I^{4}}$ & $d(\mathrm{~A})$ & $I$ \\
\hline 100 & 8.473 & & & & & 023 & 2.233 & 2.233 & 18 & 2.23 & 13 \\
\hline 110 & 6.472 & 6.475 & 7 & 6.7 & 7 & 302 & 2.161 & $\ldots \ldots$ & $\cdots$ & $\ldots \ldots$ & $\ldots \ldots$ \\
\hline 011 & 5.996 & 5.996 & 35 & 6.0 & 27 & 240 & 2.157 & 2.157 & 13 & $\ldots \ldots$ & $\ldots \ldots$ \\
\hline$\overline{1} 11$ & 5.073 & $\ldots \ldots$ & $\cdots$ & ... & & 330 & 2.157 & $\ldots \ldots$ & $\ldots \ldots$ & $\ldots \ldots$ & $\ldots \ldots$ \\
\hline 020 & 5.013 & 5.011 & 50 & 5.1 & 33 & $\overline{3} 22$ & 2.136 & 2.135 & 5 & $\ldots \ldots$ & $\ldots \ldots$ \\
\hline 111 & 4.733 & 4.733 & 7 & $\ldots$ & $\ldots \ldots$ & 400 & 2.118 & 2.118 & 35 & 2.12 & 27 \\
\hline 120 & 4.315 & $\ldots \ldots$ & $\ldots$. & $\ldots \ldots$ & $\ldots \ldots$ & 232 & 2.093 & 2.093 & 7 & $\ldots \ldots$ & $\ldots \ldots$ \\
\hline 200 & 4.237 & 4.235 & 80 & 4.27 & 100 & $\underline{410}$ & 2.073 & 2.072 & 5 & $\ldots \ldots$ & $\ldots \ldots$ \\
\hline 021 & 4.165 & 4.167 & 5 & $\ldots \ldots$ & $\ldots \ldots$ & 142 & 2.046 & $\ldots \ldots$ & & & $\ldots \ldots$ \\
\hline 210 & 3.902 & $\ldots$. & $\ldots \ldots$ & $\ldots \ldots$ & $\ldots \ldots$ & $\underline{\mathbf{2}} 23$ & 2.046 & 2.045 & 35 & 2.04 & 23 \\
\hline$\overline{1} 21$ & 3.815 & 3.814 & 5 & $\ldots \ldots$ & $\ldots \ldots$ & $\overline{4} 11$ & 2.045 & $\ldots \ldots$ & $\ldots$ & $\ldots \ldots$ & $\ldots \ldots$ \\
\hline 002 & 3.740 & 3.739 & 60 & 3.75 & 30 & 142 & 1.9986 & 1.9987 & 11 & 2.00 & 3 \\
\hline$\underline{2} 11$ & 3.587 & 3.587 & 18 & $\ldots \ldots$ & $\ldots \ldots$ & 051 & 1.9369 & 1.9368 & 35 & 1.95 & 20 \\
\hline$\overline{1} 02$ & 3.544 & $\ldots \ldots$ & $\ldots \ldots$ & $\ldots \ldots$ & $\ldots \ldots$ & $\underline{223}$ & 1.9114 & 1.9113 & 18 & $\ldots \ldots$ & $\ldots \ldots$ \\
\hline 012 & 3.504 & 3.503 & 60 & 3.51 & 27 & $\overline{1} 04$ & 1.8625 & 1.8635 & 25 & $\ldots \ldots$ & $\ldots \ldots$ \\
\hline 211 & 3.346 & 3.345 & 50 & 3.35 & 23 & 014 & 1.8384 & 1.8388 & 35 & 1.85 & 20 \\
\hline$\overline{1} 12$ & 3.341 & $\ldots \ldots$ & $\ldots \ldots$ & $\ldots \ldots$ & $\ldots$ & & & 1.7964 & 25 & $\ldots \ldots$ & $\ldots \ldots$ \\
\hline 102 & 3.311 & $\ldots \ldots$ & $\ldots \ldots$ & $\ldots \ldots$ & $\ldots$. & & & 1.7768 & 60 & 1.78 & 42 \\
\hline 220 & 3.236 & 3.238 & 90 & 3.24 & 67 & & & 1.7737 & 60 & $\ldots \ldots$ & \\
\hline 112 & 3.144 & $\ldots \ldots$ & $\ldots \ldots$ & $\ldots \ldots$ & $\ldots$ & & & 1.7476 & 60 & 1.75 & 42 \\
\hline 130 & 3.109 & $\ldots \ldots$ & $\ldots \ldots$ & $\ldots \ldots$ & $\ldots \ldots$ & & & 1.7104 & 30 & 1.71 & 13 \\
\hline 031 & 3.051 & 3.051 & 100 & 3.04 & 100 & & & 1.6929 & 7 & . & $\cdots$ \\
\hline$\overline{2} 21$ & 3.049 & $\ldots \ldots$ & $\ldots \ldots$ & $\ldots \ldots$ & $\ldots \ldots$ & & & 1.6716 & 42 & 1.67 & 23 \\
\hline 022 & 2.998 & 2.998 & 4.2 & $\ldots \ldots$ & $\ldots \ldots$ & & & 1.6320 & 35 & 1.63 & 13 \\
\hline$\underline{2} 02$ & 2.941 & 2.940 & 30 & $\ldots \ldots$ & $\ldots \ldots$ & & & 1.5982 & 18 & 1.60 & 13 \\
\hline$\overline{1} 31$ & 2.906 & $\ldots \ldots$ & $\ldots \ldots$ & $\cdots \quad \ldots \ldots$ & $\ldots \ldots$ & & & 1.5801 & 9 & $\ldots \ldots$ & $\cdots$ \\
\hline 221 & 2.897 & $\ldots$. & $\ldots \ldots$ & $\ldots \ldots$ & $\ldots \ldots$ & & & 1.5655 & 13 & 1.56 & 13 \\
\hline$\overline{1} 22$ & 2.894 & 2.894 & 7 & $\ldots \ldots$ & $\ldots \ldots$ & & & 1.5435 & 7 & $\ldots \ldots$ & $\ldots \ldots$ \\
\hline 131 & 2.837 & $\ldots \ldots$ & $\ldots \ldots$ & $\ldots \ldots$ & $\ldots \ldots$ & & & 1.5285 & 13 & $\ldots \ldots$ & $\ldots \ldots$ \\
\hline 300 & 2.824 & $\ldots \ldots$ & $\ldots \ldots$ &.$\quad \ldots \ldots$ & $\ldots \ldots$ & & & 1.51 .22 & 13 & $\ldots \ldots$ & $\ldots \ldots$ \\
\hline$\overline{2} 12$ & 2.822 & 2.820 & 18 & 2.83 & 7 & & & 1.4940 & 13 & 1.49 & 7 \\
\hline 122 & 2.763 & $\ldots \ldots$ & $\ldots \ldots$ & $\ldots \ldots$ & $\ldots \ldots$ & & & 1.4775 & 13 & $\ldots \ldots$ & $\ldots \ldots$ \\
\hline 310 & 2.719 & 2.718 & 18 & $\ldots \ldots$ & $\ldots \ldots$ & & & 1.4573 & 18 & $\ldots \ldots$ & $\ldots \ldots$ \\
\hline 202 & 2.684 & 2.685 & 35 & 2.69 & 33 & & & 1.4512 & 18 & 1.45 & 13 \\
\hline$\overline{3} 11$ & 2.631 & $\ldots \ldots$ & $\ldots \ldots$ & $\ldots \ldots$ & $\ldots \ldots$ & & & 1.4323 & 13 & $\ldots \ldots$ & $\ldots \ldots$ \\
\hline 230 & 2.624 & $\ldots \ldots$ & $\ldots \ldots$ & $\ldots \ldots$ & $\ldots \ldots$ & & & 1.4130 & 18 & 1.4 .1 & 17 \\
\hline 212 & 2.593 & 2.592 & 18 & 2.59 & 7 & & & 1.3990 & 18 & $\ldots \ldots$ & $\ldots \ldots$ \\
\hline$\overline{2} 22$ & 2.537 & $\ldots$. & $\ldots$ & $\ldots \ldots$ & $\ldots \ldots$ & & & 1.3640 & 18 & 1.36 & 13 \\
\hline$\overline{2} 31$ & 2.521 & 2.522 & 60 & 2.53 & 50 & & & 1.3478 & 11 & $\ldots \ldots$ & $\ldots \ldots$ \\
\hline 032 & 2.492 & 2.491 & 7 & $\ldots \ldots$ & $\ldots$ & & & 1.3320 & 11 & $\ldots \ldots$ & $\ldots \ldots$ \\
\hline 231 & 2.433 & 2.431 & 35 & 2.43 & 27 & & & 1.3147 & 13 & $\ldots \ldots$ & $\ldots \ldots$ \\
\hline$\overline{1} 32$ & 2.431 & $\ldots \ldots$ & $\ldots$ & $\ldots \ldots$ & $\ldots \ldots$ & & & 1.3026 & 11 & $\ldots \ldots$ & $\ldots \ldots$ \\
\hline 013 & 2.420 & 2.4 .20 & 7 & $\ldots \ldots$ & $\ldots \ldots$ & & & 1.3002 & 11 & $\ldots \ldots$ & $\ldots \ldots$ \\
\hline$\overline{3} 21$ & 2.395 & 2.395 & 7 & $\ldots$. & $\ldots \ldots$ & & & 1.2850 & 13 & $\ldots \ldots$ & $\ldots \ldots$ \\
\hline 222 & 2.366 & 2.366 & 50 & 2.37 & 30 & & & 1.2725 & 11 & & $\ldots \ldots$ \\
\hline$\overline{3} 12$ & 2.298 & 2.298 & 13 & 2.30 & 7 & & & & & & \\
\hline
\end{tabular}

${ }^{1}$ All possible calculated $d$ 's listed for $d \geqq 2.521 \mathrm{~A}$; calculated $d$ 's, $\quad{ }^{3}$ Camera diameter, 16 in.; Zr-filtered Mo radiation $(\lambda$ MoK $\alpha=0.709 \mathrm{~A})$. $\leqq 2.520 \mathrm{~A}$ and $\geqq 1.8000 \mathrm{~A}$, listed only for those observed.

${ }^{2}$ Camera diameter, $114.59 \mathrm{~mm}$; Ni-filtered Cu radiation $(\lambda \mathrm{CuK} \alpha=$ Intensities were obtained by comparison with calibrated strips.

${ }^{4}$ Intensities estimated visually by direct comparison with a calibrated $1.5418 \mathrm{~A}$ ); internal standard, $\mathrm{CaF}_{2}$. Lower limit measurable for $2 \theta$ is approximately $6.0^{\circ}(14.7 \mathrm{~A})$.

intensity filmstrip of successive step-line exposures related to each other by a factor of $\sqrt{2}$. 
Several well-formed, doubly-terminated crystals of synthetic brüggenite (fig. 4) were examined and measured on a goniometer. Crystals synthesized at $50^{\circ} \mathrm{C}$ are short prismatic, nearly equidimensional; those at $80^{\circ} \mathrm{C}$, are long prismatic parallel to $c$ (length:width:thickness averaging $1.0 \mathrm{~mm}: 0.5$ $\mathrm{mm}: 0.25 \mathrm{~mm}$ ). All the brüggenite crystals synthesized in this study are simple, having only three measurable forms: $b\{010\}, m\{110\}$, and $w\{011\}$. The form $m\{110\}$ is dominant; $b\{101\}$ is generally very narrow. General forms $\{h k l\}$ were not found on any of the many crystals examined. The absence of any positive piezoelectric response by the Giebe-Schiebe apparatus and the unequivocal space group $P 2_{1} / c$ supports our assumption that the crystal class for brüggenite is prismatic, $2 / \mathrm{m}$.

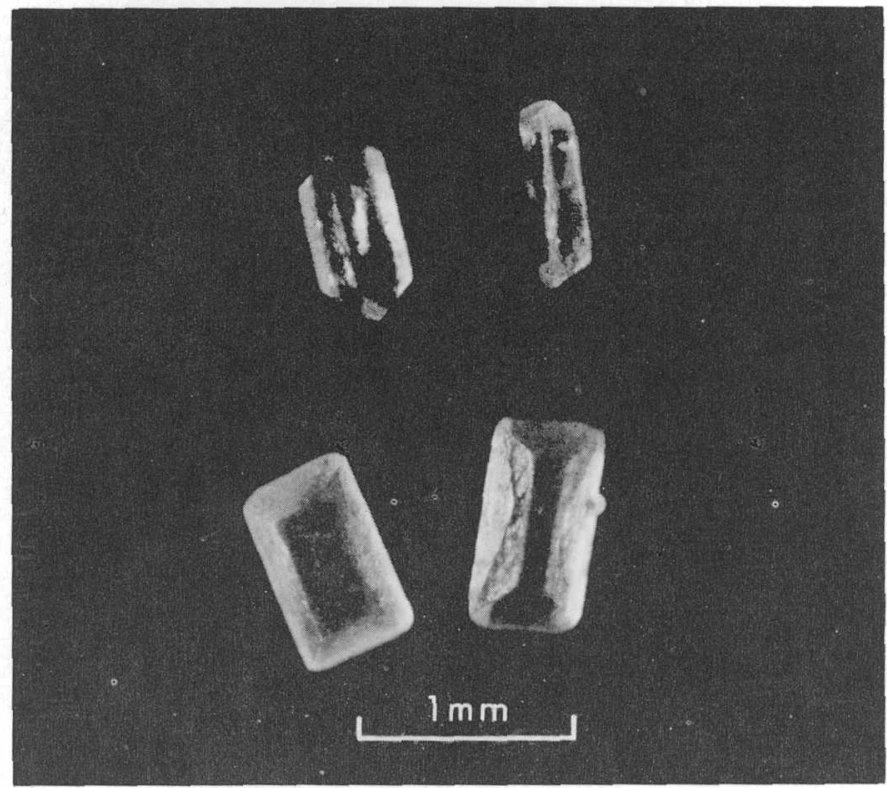

Figure 4.- Prismatic crystals of synthetic brüggenite, synthesized at $80^{\circ} \mathrm{C}$.

The angles and axial ratios for the observed forms of brüggenite, calculated from the crystallographic data cited in table 1 , are given in table 2 .

Table 2.-Angle table for brüggenite from Pampa Pique III, Oficina Lautaro, Chile

[Calculated from X-ray data in table 1]

Monoclinic; prismatic-2/m

$a: b: c=0.8486: 1: 0.7492 ; \beta=95^{\circ} 16^{\prime} ; p_{0}: q_{0}: r_{0}=0.8829: 0.7460: 1$ $r_{2}: p_{2}: q_{2}=1.3405: 1.1834: 1 ; \mu=84^{\circ} 44^{\prime}$;

$p_{0}^{\prime}=0.8866, q_{0}{ }^{\prime}=0.7492, x_{0}^{\prime}=0.0922$

\begin{tabular}{crccccc}
\hline Forms & $\phi$ & $\rho$ & \multicolumn{1}{c}{$\phi_{2}$} & $\rho_{2}=\mathrm{B}$ & $\mathrm{C}$ & $\mathrm{A}$ \\
\hline$b 010$ & $0^{\circ} 00^{\prime}$ & $90^{\circ} 00^{\prime}$ & $\cdots$ & $0^{\circ} 00^{\prime}$ & $90^{\circ} 00^{\prime}$ & $90^{\circ} 00^{\prime}$ \\
$w 011$ & $7^{\circ} 01^{\prime}$ & $37^{\circ} 03^{\prime}$ & $84^{\circ} 44^{\prime}$ & $53^{\circ} 16^{\prime} 2^{\prime}$ & $36^{\circ} 43^{\prime} \underline{2}^{\prime}$ & $85^{\circ} 47^{\prime}$ \\
$m 110$ & $49^{\circ} 48^{\prime}$ & $90^{\circ} 00^{\prime}$ & $0^{\circ} 00^{\prime}$ & $49^{\circ} 48^{\prime}$ & $85^{\circ} 59^{\prime}$ & $40^{\circ} 12^{\prime}$ \\
\hline
\end{tabular}

Crystal-structure analysis.-The crystal structures of brüggenite, lautarite, and $\mathrm{Ca}\left(\mathrm{IO}_{3}\right)_{2} \cdot 6 \mathrm{H}_{2} \mathrm{O}$ have been determined in the laboratories of the U.S. Geological Survey (unpub. data, 1973).

\section{CHEMICAL PROPERTIES}

Chemical analysis.-Material for chemical analysis was leached from specimens of nitrate ore from Pampa Pique III; from this concentrate only crystal fragments, free of visible inclusions, were handpicked for the analysis sample. X-ray patterns of selected fragments of this material indicated a mixture of brüggenite and lautarite. Attempts to separate brüggenite from lautarite in Clerici solution were unsuccessful, because both minerals reacted with this liquid.

The specific gravity of the entire sample $(500 \mathrm{mg})$ was determined by Joseph J. Fahey of the U.S. Geological Survey by pycnometer method; the value obtained, 4.387 , indicated that approximately two-thirds of the sample was brüggenite, $\mathrm{Ca}\left(\mathrm{IO}_{3}\right)_{2} \cdot \mathrm{H}_{2} \mathrm{O}$, and one-third lautarite, $\mathrm{Ca}\left(\mathrm{IO}_{3}\right)_{2}$. The chemical analysis of this $500-\mathrm{mg}$ mixture is given in column 1 of table 3; the recalculated chemical analysis (col. 2 of table 3 ), obtained by deducting the insoluble matter, $\mathrm{CO}_{2}$, and lautarite, is in good agreement with the theoretical composition, $\mathrm{Ca}\left(\mathrm{IO}_{3}\right)_{2} \cdot \mathrm{H}_{2} \mathrm{O}$, and with the analysis of crystals of brüggenite synthesized in the course of this study, also cited in table 3 .

The determinations of the chemical components (table 3), except for $\mathrm{CO}_{2}$ and $\mathrm{SrO}$, were by standard methods cited by Hillebrand, Lundell, Bright, and Hoffman (1953). Carbonate carbon was determined by gas chromatography after acid evolution (Marinenko and May, 1970); SrO was determined by atomic absorption.

Spectrographic analysis.-Prior to chemical analysis, a sample of columnar fragments of brüggenite from Pampa Pique III was submitted for semiquantitative spectrographic analysis. The spectrogram obtained by Joseph L. Harris of the U.S. Geological Survey gave the results shown below (values are reported to the nearest number in series $1,0.7,0.5,0.3,0.2$, $0.15,0.1$, and so forth, which represent approximate midpoints of group data on a geometric scale):

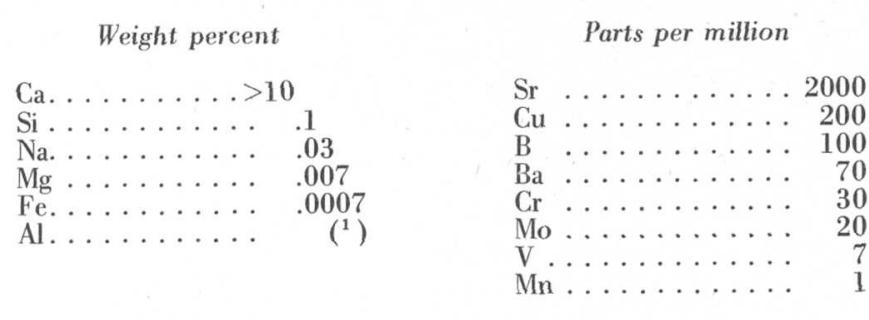

${ }^{1}$ Detected, but below limit of determination.

Note.-Looked for, not found: As, Au, Be, Bi, Cd, Ce, Co, Ga, Ge, Hf, In, K, La, Li, Nb, Ni, P, Pb, Pd, Pt, Re, Sb, Sc, Sn, Ta, Te, Th, Ti, Tl, U, W, Y, Yb, Zn, Zr. 
Table 3.-Chemical analyses of brüggenite, $\mathrm{Ca}\left(\mathrm{IO}_{3}\right)_{2} \cdot \mathrm{H}_{2} \mathrm{O}$, and its synthetic equivalent

[Analyst: John W. Marinenko]

\begin{tabular}{|c|c|c|c|c|c|c|c|}
\hline & \multicolumn{2}{|c|}{ Brüggenite } & \multicolumn{2}{|c|}{$\begin{array}{l}\text { Synthetic } \\
\text { equivalent }\end{array}$} & \multirow{2}{*}{$\begin{array}{c}\begin{array}{c}\text { Theoretical composition } \\
\text { for } \mathrm{Ca}\left(\mathrm{IO}_{3}\right)_{2} \cdot \mathrm{H}_{2} \mathrm{O}\end{array} \\
\begin{array}{c}\text { Weight } \\
\text { percent }\end{array}\end{array}$} & \multicolumn{2}{|c|}{$\begin{array}{l}\text { Cations on the basis } \\
\text { of seven oxygens }\end{array}$} \\
\hline & $\begin{array}{l}\text { Weight } \\
\text { percent }\end{array}$ & Recalculated $^{1}$ & $\begin{array}{l}\text { Weight } \\
\text { percent }\end{array}$ & Recalculated $^{2}$ & & Brüggenite & $\begin{array}{l}\text { Synthetic } \\
\text { equivalent }\end{array}$ \\
\hline $\mathrm{CaO}$ & 14.2 & 14.1 & 14.2 & 14.1 & 13.75 & $\mathrm{Ca}\}$ & 1.0 \\
\hline SrO & 0.4 & 0.4 & $\ldots \ldots$ & $\ldots \ldots$ & $\ldots$ & $\mathrm{Sr}$ & \\
\hline $\mathrm{I}_{2} \mathrm{O}_{5}$ & 81.7 & 81.4 & 80.6 & 81.4 & 81.83 & 2.0 & 2.0 \\
\hline $\mathrm{H}_{2} \mathrm{O}$ & 2.8 & 4.1 & 4.4 & 4.5 & 4.42 & 1.9 & 2.0 \\
\hline $\mathrm{CO}_{2} \ldots \ldots \ldots \ldots$ & $<0.1$ & $\ldots \ldots$ & ${ }^{3} 0.13$ & $\ldots \ldots$ & $\ldots \ldots$ & & \\
\hline Insoluble & 0.3 & $\ldots \ldots$ & $<0.1$ & $\ldots$ & $\therefore \ldots$ & & \\
\hline Total ....... & 99.4 & 100.0 & 99.3 & 100.0 & 100.00 & & \\
\hline
\end{tabular}

${ }^{1}$ Recalculated to 100.0 after deducting insoluble, $\mathrm{CO}_{2}$, and $33^{1 / 3}$ percent lautarite.

${ }^{2}$ Recalculated to 100.0 after deducting insoluble, and $\mathrm{CO}_{2}$ as $\mathrm{CaCO}_{3}$.

${ }^{3}$ Sample contained a small amount of $\mathrm{CaCO}_{3}$ (used in the synthesis) as an impurity.

${ }^{4}$ Insoluble residue in $(1: 1) \mathrm{HCl}$.

Synthesis.-Brüggenite is readily synthesized. It was prepared during this study by initially adding a 0.2 molal solution of iodic acid $\left(\mathrm{HIO}_{3}\right)$ to $9.5 \mathrm{~g}$ of reagent-grade calcium carbonate $\left(\mathrm{CaCO}_{3}\right)$. When effervescence ceased, the filtrate was carefully decanted, passed through very fine filter paper, and then held in an oven $\left(50^{\circ}-80^{\circ} \mathrm{C}\right)$ in a covered vessel until crystallization took place. Well-formed transparent doubly-terminated crystals of brüggenite were thus formed (fig. 4). They were dried between filter papers, washed successively with methyl alcohol and acetone, and air dried at room temperature. The chemical analysis of these synthetic crystals (table 3) confirmed that the composition was $\mathrm{Ca}\left(\mathrm{IO}_{3}\right)_{2} \cdot \mathrm{H}_{2} \mathrm{O}$. X-ray powder patterns for the synthetic crystals and naturally occurring brüggenite show them to be identical.

$\mathrm{X}$-ray powder data recorded for a compound synthesized and characterized as $\mathrm{Ca}\left(\mathrm{IO}_{3}\right)_{2} \cdot n \mathrm{H}_{2} \mathrm{O}$ by Kaplan (1966) in his efforts to prepare lautarite, $\mathrm{Ca}\left(\mathrm{IO}_{3}\right)_{2}$, using various methods, are in good agreement with those for brüggenite.

Solubility data.-The three known phases (fig. 5) in the system $\mathrm{Ca}\left(\mathrm{IO}_{3}\right)_{2}-\mathrm{H}_{2} \mathrm{O}\left(T<100^{\circ} \mathrm{C} ; P=1\right.$ bar $)$ include the minerals lautarite and brüggenite, which occur together in the Chilean nitrate deposits, and $\mathrm{Ca}\left(\mathrm{IO}_{3}\right)_{2} \cdot 6 \mathrm{H}_{2} \mathrm{O}$ which has not yet been found as a mineral. Solubility data presented by Hill and Brown in 1931 show $\mathrm{Ca}\left(\mathrm{IO}_{3}\right)_{2}$ to be the high-temperature phase $\left(T \geqq 57.5^{\circ} \mathrm{C}\right), \quad \mathrm{Ca}\left(\mathrm{IO}_{3}\right)_{2} \cdot \mathrm{H}_{2} \mathrm{O}$ the intermediate phase $\left(T=35^{\circ}-57.5^{\circ} \mathrm{C}\right)$, and $\mathrm{Ca}\left(\mathrm{IO}_{3}\right)_{2} \cdot 6 \mathrm{H}_{2} \mathrm{O}$ the low-temperature phase $\left(T \leqq 35^{\circ} \mathrm{C}\right)$. Furthermore, $\mathrm{Ca}\left(\mathrm{IO}_{3}\right)_{2} \cdot \mathrm{H}_{2} \mathrm{O}$ forms metastably in the temperature ranges of $25^{\circ}-35^{\circ} \mathrm{C}$ and $57.5^{\circ}-70^{\circ} \mathrm{C}$, and $\mathrm{Ca}\left(\mathrm{IO}_{3}\right)_{2}: 6 \mathrm{H}_{2} \mathrm{O}$ in the range $35^{\circ}-40^{\circ} \mathrm{C}$, as indicated in figure 5 . The presence of lautarite and brüggenite in the nitrate deposits, which probably formed at an average temperature of less than $25^{\circ} \mathrm{C}(P=1$ bar $)$, probably indicates that their stability temperatures were

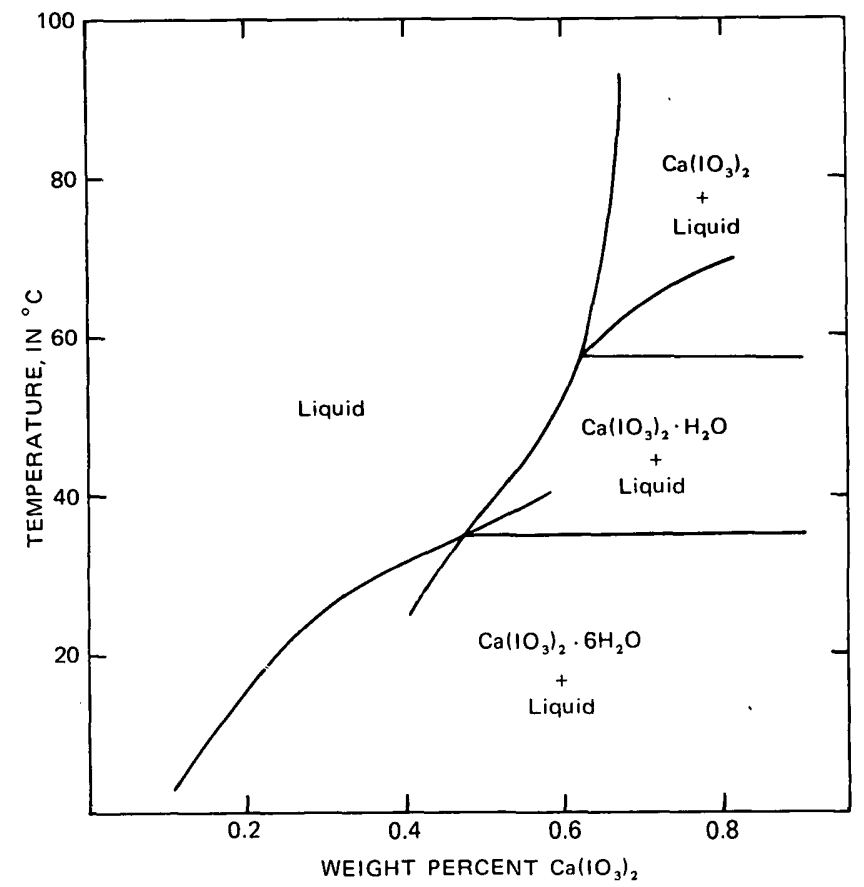

Figure 5.-The system $\mathrm{Ca}\left(\mathrm{IO}_{3}\right)_{2}-\mathrm{H}_{2} \mathrm{O}$. (From Hill and Brown, 1931, p. 4319)

depressed by other salines present in the crystallizing solutions. $\mathrm{Ca}\left(\mathrm{IO}_{3}\right)_{2} \cdot 6 \mathrm{H}_{2} \mathrm{O}$, which readily desiccates to $\mathrm{Ca}\left(\mathrm{IO}_{3}\right)_{2} \cdot \mathrm{H}_{2} \mathrm{O}$ in air at room temperature, either did not form in these solutions, which is most likely, or, if formed, became unstable as the newly formed nitrate caliche dried.

Brüggenite is readily soluble in hot water $\left(\approx 100^{\circ} \mathrm{C}\right)$ but only slowly soluble in cold water $\left(\approx 22^{\circ} \mathrm{C}\right)$. It is readily soluble in dilute to concentrated hot $\mathrm{HCl}$ and $\mathrm{HNO}_{3}$ and in moderately concentrated $(1: 1)$ to concentrated cold $\mathrm{HCl}$ and $\mathrm{HNO}_{3}$. 
Brïggenite is less soluble in dilute $(1: 10)$ cold $\mathrm{HCl}$ and only slightly soluble in $\mathrm{HNO}_{3}$ of similar concentration. It is only slightly soluble in sulfuric acid, decomposing and forming a precipitate of gypsum $\left(\mathrm{CaSO}_{4} \cdot 2 \mathrm{H}_{2} \mathrm{O}\right)$. It is insoluble in organic solvents such as alcohol, acetone, and xylol.

Pyrognostics.-Before the blowpipe, brüggenite is infusible. When heated in an open platinum crucible just below red heat, brüggenite gives off water and violet vapors of iodine; the crystals turn light reddish brown, minute cracks appear, and some exfoliation takes place. This material gives an $\mathrm{X}$-ray powder pattern of an unidentified phase, possibly $\mathrm{Ca}_{5}\left(\mathrm{IO}_{6}\right)_{2}$. At red heat in the open platinum crucible, iodine vapors are given off and the brüggenite crystals turn white and decrepitate; this residue has the $X$-ray powder pattern of $\mathrm{CaO}$. When heated in a closed tube at red heat, brüggenite first gives off water; almost immediately thereafter, copious violet vapors of iodine deposit shining black rhomboidal crystals of iodine on the walls of the upper end of the tube.

Thermogravimetric analysis. - A thermogravimetric trace (fig. 6) of brüggenite was made by Frederick O. Simon, U.S. Geological Survey, using a 100-mg sample and a thermogravimetric balance that automatically records the weight of the sample as the temperature rises $\left(4^{\circ} \mathrm{C} / \mathrm{min}\right.$ in air) to a maximum of $1,000^{\circ} \mathrm{C}$. The trace shows a loss (table 3 ) of most or all of the water $(\approx 5$ percent) between the temperatures of $210^{\circ}$ and $240^{\circ} \mathrm{C}$. The remaining material, consisting

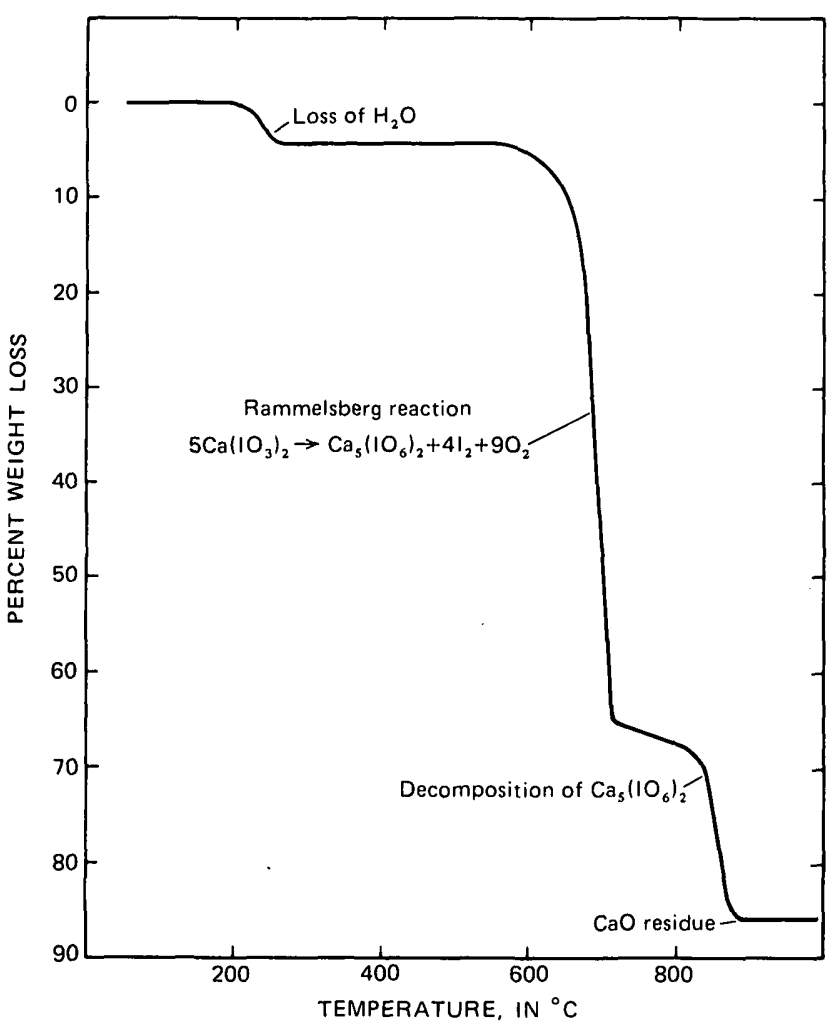

Figure 6.-Thermogravimetric trace for brüggenite, $\mathrm{Ca}\left(\mathrm{IO}_{3}\right)_{2} \cdot \mathrm{H}_{2} \mathrm{O}$, showing progressive decomposition to $\mathrm{CaO}$ upon heating. of $\mathrm{Ca}\left(\mathrm{IO}_{3}\right)_{2}$, then decomposes in two steps: (1) Between about $550^{\circ}$ and $710^{\circ} \mathrm{C}$, there is a weight loss due to loss of iodine and oxygen by the Rammelsberg reaction (Duval, 1953, p. 1.55): $5 \mathrm{Ca}\left(\mathrm{IO}_{3}\right)_{2} \rightarrow \mathrm{Ca}_{5}\left(\mathrm{IO}_{6}\right)_{2}+4 \mathrm{I}_{2}+90_{2}$, and (2) at about $710^{\circ} \mathrm{C}$, a strong inflection in the curve indicates that $\mathrm{Ca}_{5}\left(\mathrm{IO}_{6}\right)_{2}$ begins to decompose, releasing additional oxygen and the remaining iodine. Decomposition is completed at about $875^{\circ} \mathrm{C}$, leaving a residue of $\mathrm{CaO}$ equivalent to about 14 percent of the original sample.

Infrared analysis. - Infrared traces of brüggenite from Pampa Pique III, and its synthetic equivalent, for the region $4000-200 \mathrm{~cm}^{-1}$, are shown in figure 7; the principal absorption bands are listed in table 4. For comparison, the infrared frequencies for the $\mathrm{IO}_{3}$ ion and for $\mathrm{H}_{2} \mathrm{O}$ reported for the compound $\mathrm{Ca}\left(\mathrm{IO}_{3}\right)_{2} \cdot 6 \mathrm{H}_{2} \mathrm{O}$ by Miller and Wilkins (1952) and Miller, Carlson, Bentley, and Jones (1960) also are shown in table 4 .

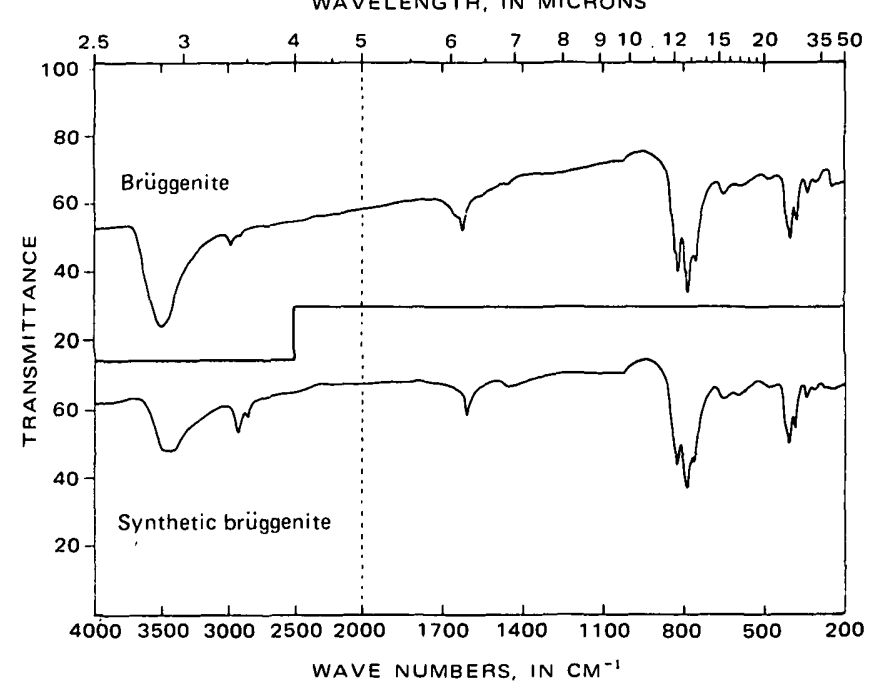

Figure 7.-Infrared traces of natural and synthetic brüggenite.

Table 4.-Infrared frequencies $\left(\mathrm{cm}^{-1}\right)$ for $\mathrm{H}_{2} \mathrm{O}$ and $\mathrm{IO}_{3}^{-}$in brïggenite, $\mathrm{Ca}\left(\mathrm{IO}_{3}\right)_{2} \cdot \mathrm{H}_{2} \mathrm{O}$, compared with those for $\mathrm{Ca}\left(\mathrm{IO}_{3}\right)_{2} \cdot 6 \mathrm{H}_{2} \mathrm{O}$

[Intensities: s, strong; m, medium; w, weak ]

\begin{tabular}{|c|c|c|c|c|c|c|}
\hline \multirow[t]{2}{*}{$\ldots$} & \multicolumn{2}{|c|}{$\mathrm{H}_{2} \mathrm{O}$} & \multicolumn{4}{|c|}{$\mathrm{IO}_{3}^{-}$} \\
\hline & $\nu_{\mathrm{S}}{ }^{1}$ & $\nu_{2}$ & $\nu_{1}$ & $\nu_{2}$ & $\nu_{3}$ & $v_{4}$ \\
\hline Brüggenite & $3500 \mathrm{~s}$ & $1625 \mathrm{~m}$ & $750 \mathrm{~s}$ & $380 \mathrm{~m}$ & $820 \mathrm{~s}$ & $335 \mathrm{w}$ \\
\hline $\mathrm{Ca}\left(\mathrm{IO}_{3}\right)_{2} \cdot 6 \mathrm{H}_{2} \mathrm{O}^{2}$ & $\begin{array}{l}2975 \mathrm{~m} \\
3350 \mathrm{~m} \\
3450 \mathrm{~m}\end{array}$ & $1610 \mathrm{w}$ & $\begin{array}{l}748 \mathrm{~s} \\
760 \mathrm{~m} \\
775 \mathrm{~s}\end{array}$ & $\begin{array}{l}400 \mathrm{~m} \\
397 \mathrm{~m} \\
367 \mathrm{~m}\end{array}$ & $817 \mathrm{~s}$ & $335 \mathrm{~m}$ \\
\hline
\end{tabular}

${ }^{1} \nu_{\mathrm{S}}=$ stretching mode $\left(\nu_{1}\right.$ and $\left.\nu_{3}\right)$

${ }^{2}$ Frequencies from Miller and Wilkins (1.952, p. 1.258); Miller, Carlson, Bentley, and Jones (1960, p. 217).

The infrared curves were made by Irving A. Breger, U.S. Geological Survey, with a Perkin-Elmer Model 621 
spectrophotometer, utilizing $\mathrm{KBr}$ disks consisting of a mixture of $0.500 \mathrm{mg} \mathrm{Ca}\left(\mathrm{IO}_{3}\right)_{2} \cdot \mathrm{H}_{2} \mathrm{O}$ and $300 \mathrm{mg} \mathrm{KBr}$. The absorption bands (table 4) were identified by comparison of the spectra shown in figure 7 with spectra of iodate compounds $\left(\mathrm{NaIO}_{3}\right.$, $\mathrm{KIO}_{3}$, and $\left.\mathrm{Ca}\left(\mathrm{IO}_{3}\right)_{2} \cdot 6 \mathrm{H}_{2} \mathrm{O}\right)$ presented by Miller and Wilkins (1952) and Miller, Carlson, Bentley, and Jones (1960). Vibrational modes $(\nu)$ for the $\mathrm{IO}_{3}$ ion were assigned by comparison with the fundamental vibrational frequencies listed by Nakamoto $\left(1963\right.$, p. 87); those for $\mathrm{H}_{2} \mathrm{O}$ were assigned by comparison with spectra by Adler (1965).

\section{ACKNOWLEDGMENTS}

These investigations were carried out under the auspices of the U.S. Geological Survey in cooperation with the Instituto de Investigaciones Geologicas of Chile. We wish to thank our colleagues of the U.S. Geological Survey for contributions to this study: Ray E. Wilcox, for spindle-stage determination of some of the optical properties, which allowed refinement of our earlier determinations (Mrose and others, 1971); Joseph L. Harris, for the semiquantitative spectrographic analysis; Judith Konnert, for the unit-cell refinement; Frederick O. Simon, for the thermogravimetric trace; and Irving A. Breger, for the infrared traces. We also thank our Chilean colleagues Fernando Munizaga and Mauricio Tabac for their collaboration in the field study that resulted in the discovery of brüggenite.

\section{REFERENCES CITED}

Adler, H. H., 1965, Examination of mass-radius effects, hydrogen bonding and $\nu_{b}$ splitting in infrared spectra of $\mathrm{Zr}$-Hf homologs: Am. Mineralogist, v. 50, no. 10, p. 1553-1562.
Appleman, D. E. and Evans, H. T., Jr., 1973, Indexing and least-squares refinement of powder diffraction data: U.S. Dept. Commerce, Natl. Tech. Inf. Service PB-216 188, $67 \mathrm{p}$.

Duval, Clement, 1953, Inorganic thermogravimetric analysis: New York, Elsevier Pub. Co., 531 p.

Ericksen, G. E., and Mrose, M. E., 1972, High-purity veins of soda-niter, $\mathrm{NaNO}_{3}$, and associated saline minerals in the Chilean nitrate deposits, in Geological Survey research 1972: U.S. Geol. Survey Prof. Paper 800-B, p. B43-B49.

Hill, A. E., and Brown, S. F., 1931, Ternary systems. XV. Potassium iodate, potassium nitrate, and water. XVI. Calcium iodate, sodium iodate, and water: Am. Chem. Soc. Jour., v. 53, p. 4316-4320.

Hillebrand, W. F., Lundell, G. E. F., Bright, H. A., and Hoffman, J. I., 1953, Applied inorganic analysis: New York, John Wiley and Sons, 1034 p.

Kaplan, S. F., 1966, An X-ray diffraction study of some of the naturally occurring iodates: Ann Arbor, Univ. Michigan, Univ. Microfilms, Inc., $186 \mathrm{p}$.

Marinenko, J. W., and May, Irving, 1970, Gas chromatographic determination of carbonate carbon in rocks and minerals, in Geological Survey research 1970: U.S. Geol. Survey Prof. Paper 700-D, p. D103-D105.

Miller, F. A., Carlson, G. L., Bentley, F. F., and Jones, W. H., 1960, Infrared spectra of inorganic ions in the cesium bromide region $\left(700-300 \mathrm{~cm}^{-1}\right)$ : Spectrochim. Acta, v. 16, p. 135-235.

Miller, F. A., and Wilkins, C. H., 1952, Infrared spectra and characteristic frequencies of inorganic ions: Anal. Chemistry, v. 24, p. $1253-1294$.

Mrose, M. E., Ericksen, G. E., and Marinenko, J. W., 1971, Brüggenitè, $\mathrm{Ca}\left(\mathrm{IO}_{3}\right)_{2} \cdot \mathrm{H}_{2} \mathrm{O}$, a new saline mineral from the Chilean nitrate deposits [abs.]: Clay Minerals Conf., 20th, Rapid City, S. Dak., Ann. Mtg., Program, p. 13.

Nakamoto, Kazuo, 1963, Infrared spectra of inorganic and coordination compounds: New York, John Wiley and Sons, $328 \mathrm{p}$.

Osann, A., 1894, Krystallographische Untersuchung einiger neuer chilenischer Mineralien: Zeitschr. Kristallographie, v. 23, p. 584-589. 
Jour. Research U.S. Geol. Survey

Vol. 2, No. 4, July-Aug. 1974, p. 479-481

\title{
A MINERAL SEPARATION PROCEDURE USING HOT CLERICI SOLUTION
}

\author{
By SAM ROSENBLUM, Denver, Colo.
}

\begin{abstract}
Careful boiling of Clerici solution in a Pyrex test tube in an oil bath is used to float minerals with densities up to 5.0 in order to obtain purified concentrates of monazite (density 5.1 ) for analysis. The "sink" and "float" fractions are trapped in solidified Clerici salts on rapid chilling, and the fractions are washed into separate filter papers with warm water. The hazardous nature of Clerici solution requires unusual care in handling.
\end{abstract}

The preparation and use of Clerici solution for sink-float separation of heavy minerals has been discussed by many investigators (Muller, 1967). This solution has been in use at least $65 \mathrm{yr}$ for separation of minerals containing tin, chromium, niobium-tantalum, the rare-earth metals, and so forth from "medium-heavy" minerals (density between 2.85 and 3.30 ) by investigators who were aware of its potential as well as its hazardous nature. Pertinent information about this solution is summarized as follows:

I. Clerici solution is an aqueous solution of equal parts of thallium formate and thallium malonate. A saturated solution at $20^{\circ} \mathrm{C}$ consists of about $500 \mathrm{~g}$ of each salt in $1.00 \mathrm{ml}$ of water and has a density $(D)$ of 4.28 .

2. The index of refraction at room temperature varies directly with the density of the solution (fig. 1), which is dependent upon the concentration. Thus densities up to that of the saturated solution may be determined indirectly by means of a refractometer. The data for figure 1 were collected in the Mineralogy Laboratory of the Liberian Geological Survey under the ambient temperature of $24^{\circ} \mathrm{C}$.

3. This expensive solution may be recovered by carefully boiling hot water washings from minerals and containers until a chip of corundum $(D=4.05 \pm 0.05)$ barely floats. When cooled to room temperature, this solution should have a minimum precipitation of thallium salts and a density of about $4.30 \pm 0.05$ once again. Boiling beyond this just-float point may produce a useless decomposition mixture of brown salts and thallium metal.

4. Note: The solution is cited as poisonous, and Sax (1957, p. 1.175) states (of thallium compounds), "Acute poisoning usually follows the ingestion of toxic quantities." Milner (1.962, p. 1.20-121) listed Clerici solution among other heavy liquids and warned that it is "exceedingly poison-

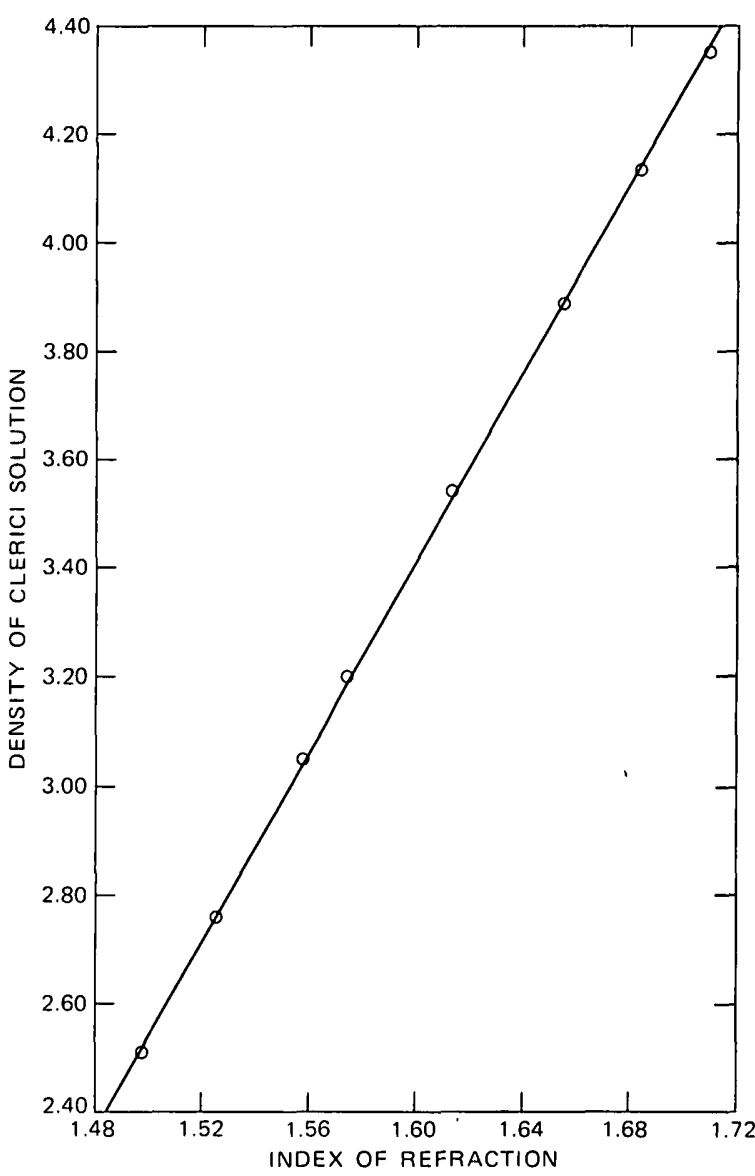

Figure 1.-Clerici solution density versus index of refraction at $24^{\circ} \mathrm{C}$.

ous and the greatest care should be taken in [its] manipulation." Rubber gloves may be used, but I recommend frequent washing of the bare hands as a safer procedure. Unusual care is urged in handling vessels containing the solution and in avoiding any fumes from heated solutions. A well-ventilated area, preferably a fumehood, is required. With these precautions, the solution can be handled safely.

This note discusses the use of the solution at elevated temperatures and describes a simple procedure for attaining densities as high as 5.1, high enough to float monazite. The data given here are the result of experimentation with 
beach-sand samples to perfect a simple and rapid method of purifying monazite concentrates for chemical analysis. This required separation of considerable rutile, altered zircon, and spinel that were extracted in the same magnetic susceptibility range after sinking in methylene iodide $(D=3.20)$. By means of the following procedure, a 5- to $20 \mathrm{~g}$ monazite concentrate with no more than 1 percent of other minerals was obtained in each of five successive runs. The first test was done with utmost caution and took about $4 \mathrm{~h}$; the last run, accomplished with confidence based on brief experience, took $55 \mathrm{~min}$.

This work was part of a cooperative mineral-resources evaluation project conducted by the Liberian Geological Survey and the U.S. Geological Survey under a program sponsored by the Republic of Liberia and the Agency for International Development, U.S. Department of State.

\section{CLERICI SOLUTION AT ELEVATED TEMPERATURES}

According to Muller (1967, p. 9), "With increasing temperature and concentration of salts, densities of 4.65 at $50^{\circ} \mathrm{C}$ and about 5.0 at $90^{\circ} \mathrm{C}$ may be obtained." I infer that the solutions are saturated and that considerable time is required to maintain equilibrium conditions between heating and fluidity. A literature search uncovered no techniques for utilizing the higher densities at elevated temperatures, and so I experimented and devised surprisingly simple techniques that immediately yielded successful results. Briefly, the solution is vigorously boiled in a test tube to arrive swiftly at the desired density, as indicated by density chips, and the sample to be separated is added carefully. Quick cooling of the tube then solidifies the solution, trapping minerals above and below.

Saturated Clerici solution (at room temperature) boils at about $125^{\circ} \mathrm{C}$. As water is driven off, the density of the solution increases, and the temperature must be gradually raised to keep the solution at a constant vigorous boil without frothing out of the tube. On cooling, this solution becomes supersaturated and solidifies to a crystal mush or a solid mass, depending upon the amount of water driven off. Thus, it is impractical to try to filter the hot solution without maintaining the filter funnel at the same or higher temperature. To avoid this problem, as well as the potentially dangerous pouring of hot Clerici solution after a separation is effected, the solution is allowed to solidify in a test tube and is treated as a fused salt. The "float" minerals are trapped in the upper part of the solidified solution and are easily washed out into a filter paper by means of small squirts of warm distilled water from a plastic squeeze bottle. The "sink" fraction at the bottom of the test tube is washed out into another filter paper. Both fractions are then washed with warm to hot water to recover the solution, rinsed with acetone, and dried under heat lamps. The washings are concentrated again as described above.
The density (4.10) of the solution that floats corundum increases to about 4.30 on cooling; similarly the density of a solution at 4.70 increases to about 4.90 on solidifying. The concentrate is added to the solution when a zircon granule just becomes suspended in the boiling solution. The density of the solution increases gradually on cooling, and all the zircon floats before solidification starts.

\section{APPARATUS AND PROCEDURE}

Figure 2 shows the simple apparatus used in hot Clericisolution separations. A graduated Pyrex test tube about 20 $\mathrm{mm}$ in diameter, $115 \mathrm{~mm}$ long, and holding $20 \mathrm{ml}$ of saturated solution is immersed in cooking oil in a 400-ml Pyrex beaker heated on an electric hotplate. A thermometer is placed in the oil close to the middle of the test tube; the temperature of boiling Clerici solution was found to be about $5^{\circ} \mathrm{C}$ less than that of the oil bath. A large-bore plastic tube connected to a faucet aspirator is inserted through a loose-fitting plastic plug

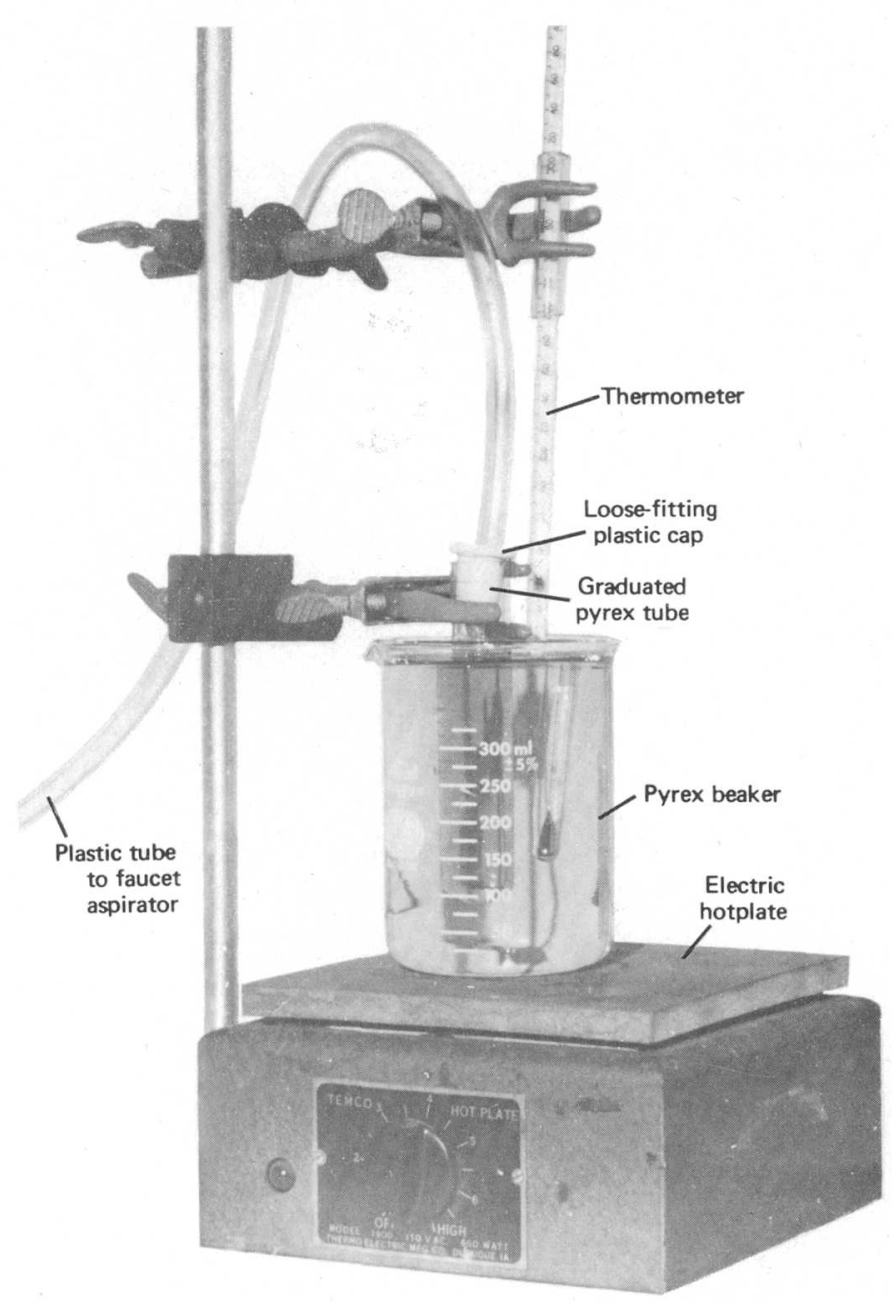

Figure 2.-Apparatus for mineral separation in hot Clerici solution. 
at the top of the test tube to draw off water vapor from above the boiling Clerici solution. For monazite separations, small granules of monazite $(D=5.09)$ and zircon $(D=4.70)$ are placed in the solution to serve as boiling chips as well as to indicate the density of the hot solution. For separations of minerals in the density range 3.20 to 4.70 , suitable mineral or density chips may be used to indicate the approximate density.

The oil bath is quickly heated and boiling commences in the Clerici solution in about $20 \mathrm{~min}$. Rapid, even boiling is desired to drive off water without boiling over. Allowance should be made to enable speedy lifting of the test tube to reduce heating if the boiling becomes too rapid. The aspirator is turned on at the start of boiling and the tubing is arranged so that the water vapor, on condensing, is led away from the test tube and does not drop back into it. To continue the rapid boiling, the temperature of the oil needs to be raised to $140^{\circ} \mathrm{C}$ at about 30 min., $150^{\circ} \mathrm{C}$ at about $40 \mathrm{~min}$., and $152^{\circ}$ to $154^{\circ} \mathrm{C}$ at about 50 min. after the start. During this time, the solution level drops, owing to evaporation of 3 to $4 \mathrm{ml}$ of water. The zircon grain becomes suspended, circulates up and down, and finally rises to the surface. If the evaporation inadvertently goes so far that the monazite granule is suspended, a few drops of water stirred into the solution will reduce the density to the point where the monazite chip sinks and the zircon chip is suspended or just floats. About 5 to $20 \mathrm{~g}$ of monazite concentrate are added slowly and cautiously to avoid frothing over, and the mixture is stirred carefully and removed from the oil bath.

To expedite rapid separations of 15 to $20 \mathrm{~g}$ of concentrate, the hot test tube may be centrifuged at low speed for a few minutes before final cooling. The counterweight to be required in the centrifuge may be determined by removing the test tube from the oil bath, weighing it, and then returning the tube to the hot oil to keep the Clerici solution fluid while a counterweight is prepared. A similar tube containing lead shot provides an adequate counterweight for the centrifuge.

On cooling rapidly (in a beaker in a freezer chest) for about 10 to $15 \mathrm{~min}$, the supersaturated solution solidifies, trapping the "sink" and "float" fractions which are separated by a column of 3 to $4 \mathrm{~cm}$ of solidified Clerici salt. Each fraction is then washed into filter papers as described above.

\section{CAUTIONARY NOTES}

Certain difficulties that arose in working out the above procedure are worth reporting:
1. A tight-fitting rubber stopper was used in one run between the 1.0-mm-diameter plastic tubing from the aspirator and the test tube to reduce the air pressure above the solution and to promote boiling at a lower temperature. Because of inadequate control, most of the boiling solution was inadvertently sucked into the 2-m-long plastic tubing. The solution was flushed carefully back into large beaker (kept nearby for the stirring rod) and recovered by filtering and boiling. This incident demonstrated that ambient air pressure affords best boiling control. A loose-fitting plastic insert is now used to hold the end of the plastic tubing 5 to $10 \mathrm{~mm}$ above the boiling solution.

2. On one run, the concentrate was added to the hot Clerici solution too rapidly and the sudden frothing caused considerable solution to overflow into the hot oil. In that event, the beaker of oil should be removed from the hotplate before the Clerici solution at the bottom can be decomposed by excess heat. After the oil bath is cooled below $100^{\circ} \mathrm{C}$ the solution may be diluted with water and recovered from the oil by means of a separatory funnel. Such difficulties can be prevented by positioning about $15 \mathrm{~cm}$ of the plastic tubing to the aspirator vertically above the boiling Clerici solution to suck up any excessive frothing. The froth rapidly resumes liquid form and drops back into the test tube.

These were the only accidents experienced in developing this simple procedure. Doubtless, more intricate procedures with more sophisticated equipment may be developed to accommodate many separations of this sort. For a mineralogical laboratory in which a few small samples need to be separated in hot Clerici solution, this method is adequate. Nevertheless, the need for extreme caution in handling Clerici solution, hot or cold, cannot be overemphasized.

\section{REFERENCES CITED}

Milner, H. B. and others, eds. 1962, Sedimentary petrography-v. 1, Methods in sedimentary petrography: New York, Macmillan Co., $643 \mathrm{p}$.

Muller, L. D., 1967, Laboratory methods of mineral separation, in Zussman, J., ed., Physical methods in determinative mineralogy: New York, Academic Press, p. 1-30.

Sax, N. I., 1957, Dangerous properties of industrial materials: New York, Reinhold Pub. Corp., 1,467 p. 



\title{
A SENSITIVE AND RAPID METHOD FOR THE DETERMINATION OF TRACE AMOUNTS OF SELENIUM IN GEOLOGIC MATERIALS
}

\author{
By GEORGE L. CRENSHAW and HUBERT W. LAKIN, Denver, Colo.
}

\begin{abstract}
A sensitive method for the determination of less than crustal abundance amounts of selenium has been developed that can be useful in the geochemical investigation of selenium. The sample is roasted with a flux of sodium carbonate, chloride, and chlorate and then digested in a mixture of nitric and phosphoric acids. The resulting solution is stabilized; the selenium is reacted with 2,3-diaminonaphthalene to form 4,5-benzopiazselenol, extracted with cyclohexanc, and measured fluorometrically. The lower limit of selenium content of a sample that can be determined by this method is $0.04 \mathrm{p} / \mathrm{m}$ using a $0.5-\mathrm{g}$ simple.
\end{abstract}

Selenium, found as an impurity in most sulfide minerals, is promising as a pathfinder element because it is almost completely retained in weathered material (ferric oxide gossans) which thus becomes a resistate. The element is one of the least abundant in the Earth's crust (Parker, 1967) and requires very sensitive methods for its determination.

The very great interest in selenium as a required nutrient for domestic animals has led to the development of excellent methods of analysis of biological materials for minute amounts of selenium (Watkinson, 1967; Levesque and Vendette, 1971; Hemsted and others, 1972). However, the analysis of geologic materials has not received equal attention and sensitive methods are not equally available. Atomic-absorption spectrophotometry has been used recently for selenium, but the practical sensitivity of that method is inadequate (Severne and Brooks, 1972). The estimation of selenium by X-ray fluorescence after preconcentration of the element offers a sensitivity of $0.1 \mathrm{p} / \mathrm{m}$ selenium, which is adequate for many materials ( $\mathrm{J}$. S. Wahlberg, unpub. data, 1.974).

The method presented in this paper is a modification of one reported by Wells (1965), who used a phosphoric-nitric acid digestion and. DAN (2,3-diaminonaphthalene) as the color-forming agent. In the present method the samples are roasted with sodium carbonate, chloride, and chlorate in an initial treatment to oxidize organic matter, sulfides, and native sulfur without apparent loss of selenium; the samples are then digested with phosphoric and nitric acids to effect solution of the selenium. After adjustment of the $\mathrm{pH}$ and addition of complex-forming reagents, a stable DAN solution (Wilkie and Young, 1970) is added to form the piazselenol (Parker and
Harvey, 1962) which is extracted with cyclohexane, and the selenium is measured by the fluorescence of the piazselenol on a fluorometer.

The method offers an adequate sensitivity of $0.04 \mathrm{p} / \mathrm{m}$ selenium in a 0.5-g sample and good reproducibility.

Thirty samples can be analyzed per man per day by the proposed method.

\section{REAGENTS AND APPARATUS}

\section{Reagents}

Note: Analytical reagent grade chemicals should be used where possible; demineralized water was used.

Ammonium hydroxide $\left(\mathrm{NH}_{4} \mathrm{OH}\right)$, concentrated.

$\mathrm{NH}_{4} \mathrm{OH}$ solution, $4 \mathrm{~N}$ : Dilute $300 \mathrm{ml}$ of concentrated $\mathrm{NH}_{4} \mathrm{OH}$ to 1 liter with water.

Ammonium oxalate.

Ammonium oxalate solution, saturated: Solution of ammonium oxalate in water.

Boiling chips: Amphoteric alundum granules, plain.

Cyclohexane, practical grade.

2,3-diaminonaphthalene (DAN).

DAN, 0.1 percent solution: Dissolve $0.5 \mathrm{~g}$ of DAN in $50 \mathrm{ml}$ concentrated $\mathrm{HCl}$ and dilute to $500 \mathrm{ml}$ with water. Extract three times with $25-\mathrm{ml}$ portions of cyclohexane, discarding the organic phase each time. Extract three times with $25-\mathrm{ml}$ portions of hexane, discarding the organic phase each time. Store in refrigerator in a dark-colored bottle under a $0.5-\mathrm{cm}$ layer of hexane.

(Ethylenedinitrilo)tetraacetic acid disodium salt (sodium salt of EDTA).

Flux mixture one: Six parts $\mathrm{Na}_{2} \mathrm{CO}_{3}$ powder, 2 parts $\mathrm{NaCl}$, and 1 part $\mathrm{NaClO}_{3}$. The $\mathrm{NaCl}$ and $\mathrm{NaClO}_{3}$ are mixed and ground to a powder, then mixed thoroughly with the $\mathrm{Na}_{2} \mathrm{CO}_{3}$.

Flux mixture two: One part $\mathrm{Na}_{2} \mathrm{CO}_{3}$ and one part $\mathrm{NaClO}_{3}$. Grind and mix thoroughly.

Hexane ${ }_{2}$ practical grade.

Hydrochloric acid ( $\mathrm{HCl})$, concentrated.

$\mathrm{HCl}$. solution, $0.1 \mathrm{~N}$ : Dilute $8.3 \mathrm{ml}$ of concentrated $\mathrm{HCl}$ to 1 .

liter with water.

Hydroxylamine hydrochloride $\left(\mathrm{NH}_{2} \mathrm{OH} \cdot \mathrm{HCl}\right)$.

Nitric acid $\left(\mathrm{HNO}_{3}\right)$, concentrated. 
$\mathrm{HNO}_{3}$ solution, $4 \mathrm{~N}$ : Dilute $255 \mathrm{ml}$ concentrated $\mathrm{HNO}_{3}$ to 1 liter with water.

Phosphoric acid $\left(\mathrm{H}_{3} \mathrm{PO}_{4}\right)$, concentrated.

Quinine sulfate.

Quinine sulfate solution, $100 \mu \mathrm{g} / \mathrm{ml}$ : Dissolve $0.1 \mathrm{~g}$ quinine sulfate in $100 \mathrm{ml}$ of 1 percent $\mathrm{H}_{2} \mathrm{SO}_{4}$ in water.

Quinine sulfate solution, $2 \mu \mathrm{g} / \mathrm{ml}$ solution: Dilute $2 \mathrm{ml}$ of the $100 \mu \mathrm{g} / \mathrm{ml}$ solution to $100 \mathrm{ml}$ with 1 percent $\mathrm{H}_{2} \mathrm{SO}_{4}$ in water.

Selenium (Se) metal, 99.9 percent pure.

Selenium standard, $1,000 \mu \mathrm{g} / \mathrm{ml}$ : Dissolve $1.0 \mathrm{~g}$ pure selenium metal in $29 \mathrm{ml}$ concentrated $\mathrm{HNO}_{3}$. Add another $225 \mathrm{ml}$ concentrated $\mathrm{HNO}_{3}$ and dilute to 1 liter with water.

Selenium standard, $100 \mu \mathrm{g} / \mathrm{ml}$ : Dilute $10 \mathrm{ml}$ of the 1,000 $\mu \mathrm{g} / \mathrm{ml}$ standard to $100 \mathrm{ml}$ with $4 \mathrm{NHNO}_{3}$.

Selenium standard, $10 \mu \mathrm{g} / \mathrm{ml}$ : Dilute $10 \mathrm{ml}$ of the $100 \mu \mathrm{g} / \mathrm{ml}$ standard to $100 \mathrm{ml}$ with $4 \mathrm{NHNO}_{3}$.

Selenium standard, $1 \mu \mathrm{g} / \mathrm{ml}$ : Dilute $10 \mathrm{ml}$ of the $10 \mu \mathrm{g} / \mathrm{ml}$ standard to $100 \mathrm{ml}$ with $4 \mathrm{NHNO}_{3}$.

Sodium carbonate $\left(\mathrm{Na}_{2} \mathrm{CO}_{3}\right)$, anhydrous powder.

Sodium chlorate $\left(\mathrm{NaClO}_{3}\right)$.

Sodium chloride $(\mathrm{NaCl})$.

Sodium tartrate.

Sodium tartrate, 10 percent solution: Dissolve $10 \mathrm{~g}$ of sodium tartrate in $100 \mathrm{ml}$ water.

Stabilizer solution: Dissolve $30 \mathrm{~g}$ of EDTA $(0.08 M)$ in a liter of 10 percent solution of $\mathrm{NH}_{2} \mathrm{OH} \cdot \mathrm{HCl}$ in water.

Sulfuric acid $\left(\mathrm{H}_{2} \mathrm{SO}_{4}\right)$, concentrated.

\section{Apparatus}

Culture tubes, 16 by $150 \mathrm{~mm}$, Pyrex.

Erlenmeyer flasks, 50-ml capacity.

Fluorometer tubes, 13 by $67 \mathrm{~mm}$.

Fluorometer: An instrument capable of excitation at $366 \mathrm{~nm}$ and measurement of radiation at $525 \mathrm{~nm}$ is required. The instrument used in this work was a Jarrell Ash model JA-2600 equipped with a source of two 4-W fluorescent lamps, a secondary filter system at $510 \mathrm{~nm}$, and a detector (type 931-A photomultiplier).

Hotplate: Oscillating, 12 by 20 in. $(30.5$ by $51 \mathrm{~cm})$, electric with temperature control from $100^{\circ}$ to $260^{\circ} \mathrm{C}$.

\section{PROCEDURE}

\section{Roasting of samples}

Three different kinds of geologic materials with which selenium may be associated require three different roasts to initiate the first stage of oxidation on their samples. These materials and their roasting requirements are as follows: (A) Subsoils and rocks in which the principal minerals are silicates may require larger samples but less flux, because the selenium content is usually low in these materials, (B) sulfides and soils or rocks with organic matter require a smaller sample and more flux to oxidize the sulfur and organic matter present; selenium is usually associated with sulfides and frequently with carbonaceous shale, and (C) native sulfur requires a smaller sample and a roast that prevents the sulfur from igniting, followed by another roast to complete the oxidation of the sulfur present; selenium is associated with volcanic sulfur.

A. Roasting of subsoil and rock: Weigh $0.5 \mathrm{~g}$ of pulverized sample into a 16 by $150 \mathrm{~mm}$ Pyrex culture tube. Add an equal amount of flux 1 ; mix and roast in bunsen burner flame until the mixture appears to be moist from incipient melting.

B. Roasting of sulfides and soils with organic matter; Weigh $0.2 \mathrm{~g}$ of pulverized sample into a 16 by $150 \mathrm{~mm}$ Pyrex culture tube. Add $0.4 \mathrm{~g}$ of flux 1 ; mix and roast in bunsen burner flame until the mixture appears to be moist from incipient melting.

C. Roasting of samples having high content of native sulfur: Weigh $0.1 \mathrm{~g}$ of pulverized sample into a 16 by $150 \mathrm{~mm}$ Pyrex culture tube. Add $0.2 \mathrm{~g}$ of $\mathrm{Na}_{2} \mathrm{CO}_{3} ; \mathrm{mix}$ and cautiously heat in bunsen burner flame until sulfur begins to condense on walls of culture tube; let culture tube cool; then add $0.1 \mathrm{~g}$ of flux 2 ; mix and roast in bunsen burner flame again until the mixture is completely melted.

\section{Acid digestion of roasted samples}

Let the roasted sample cool; then add two or three boiling chips, $0.5 \mathrm{ml}$ water, and $5 \mathrm{ml} \mathrm{HNO}_{3}$; mix. Add $3 \mathrm{ml}$ of $\mathrm{H}_{3} \mathrm{PO}_{4}$ and mix again. Heat culture tube to boiling on the hotplate and boil at least $1 \mathrm{~h}$.

Cool and centrifuge culture tube for $5 \mathrm{~min}$. Decant supernatant liquid into a $50 \cdot \mathrm{ml}$ erlenmeyer flask, wash the walls of the culture tube with water, and add washings to the erlenmeyer flask. Heat to boiling to reduce the volume of liquid in the erlenmeyer flask to about $8 \mathrm{ml}$. At this stage the sample can stand for at least $5 \mathrm{~d}$. To the cool erlenmeyer flask add $10 \mathrm{ml}$ of a saturated ammonium oxalate solution and boil for $10 \mathrm{~min}$. After the addition of ammonium oxalate solution the determination must continue without interruption through the extraction of the piazselenol.

\section{Stabilization of sample solution}

Allow the sample to cool and add $5 \mathrm{ml} 4 \mathrm{~N} \mathrm{NH}_{4} \mathrm{OH}$, and adjust $\mathrm{pH}$ to 1.1 with $4 \mathrm{~N} \mathrm{NH} \mathrm{NH}_{4} \mathrm{OH}$. Add $1 \mathrm{ml}$ of 10 percent sodium tartrate solution and $5 \mathrm{ml}$ of stabilizer solution. The volume of solution at this stage is about $40 \mathrm{ml}$.

\section{Formation and extraction of piazselenol}

Subdued light is required during subsequent steps of the analysis. Add $3 \mathrm{ml}$ of a 0.1 percent solution of DAN, heat to about $50^{\circ} \mathrm{C}$, and let stand in the dark while it cools for $1 \mathrm{~h}$. Transfer the sample to a 125-ml separatory funnel. Add $5 \mathrm{ml}$ cyclohexane, stopper the separatory funnel, and shake funnel 
$30 \mathrm{~s}$. After the phases separate, discard the aqueous phase, add $25 \mathrm{ml}$ of $0.1 \mathrm{~N} \mathrm{HCl}$, and shake $5 \mathrm{~s}$; allow the phases to separate and discard the aqueous phase. Again add $25 \mathrm{ml}$ of $0.1 \mathrm{~N} \mathrm{HCl}$, shake $5 \mathrm{~s}$, and discard the aqueous phase. Transfer the cyclohexane to a fluorometer tube and centrifuge $2 \mathrm{~min}$.

\section{Fluorometric measurement of selenium}

Read the fluorescence on the fluorometer using $5 \mathrm{ml}$ of the $2 \mu \mathrm{g} / \mathrm{ml}$ quinine sulfate solution in one fluorometer tube for background and reference. Selenium is estimated from a previously prepared standard curve:

$$
\text { selenium in parts per million }=\frac{\text { microgram reading }}{\text { sample weight, in grams }} \text {. }
$$

Preparation of the standard curve is as follows:

For $0.1 \mathrm{X}$ scale: Add $0,0.02,0.04,0.08$, and $0.15 \mu \mathrm{g}$ of sclenium to five different $50-\mathrm{ml}$ erlenmeyer flasks. Take these standards through the procedure beginning with the addition of $5 \mathrm{ml}$ of $\mathrm{HNO}_{3}$ and $5 \mathrm{ml} \mathrm{H}_{3} \mathrm{PO}_{4}$ to each flask and boil until the volume of the solution is approximately $8 \mathrm{ml}$. Use the zero for the blank reading. Plot microamperes reading versus micrograms per $5 \mathrm{ml}$ cyclohexane. The curve obeys Beer's law through $0.15 \mu \mathrm{g} / 5 \mathrm{ml}$ cyclohexane.

For 1.0X scale: Add $0.2,0.6,1.5,3.0$, and $5.0 \mu \mathrm{g}$ of selenium to five different $50-\mathrm{ml}$ erlenmeyer flasks. Take these standards through the procedure beginning with the addition of $5 \mathrm{ml} \mathrm{HNO}$ and $5 \mathrm{ml} \mathrm{H} \mathrm{HO}_{4}$ to each flask and boil until the volume of the solution is approximately $8 \mathrm{ml}$. Use the zero from the $0.1 \mathrm{X}$ scale to determine the blank for this scale. Plot microamperes reading versus micrograms per $5 \mathrm{ml}$ of cyclohexane. The curve obeys Beer's law through 5.0 $\mu \mathrm{g} / 5 \mathrm{ml}$ cyclohexane.

If the sample solution contains more than $5 \mu \mathrm{g}$ of selenium, the sample must be rerun, using a smaller weight or smaller aliquot of the liquid sample. This is evidenced from the standard curve.

\section{EXPERIMENTAL TECHNIQUES}

\section{Direct acid digestion}

An attempt was made to determine selenium by various acid digestions directly on the sample (table 1). Rocks and soils of varying composition were used with the following acid digestions:

A. A mixture of $5 \mathrm{ml}$ each of nitric, perchloric, and hydrofluoric acid.

B. A mixture of $5 \mathrm{ml}$ each of nitric and perchloric acid.

C. A mixture of $5 \mathrm{ml}$ each of nitric and perchloric and $2 \mathrm{ml}$ hydrofluoric acid.

D. A mixture of $5 \mathrm{ml}$ each of nitric and phosphoric and $3 \mathrm{ml}$ hydrofluoric acid.

E. A mixture of $5 \mathrm{ml}$ each of nitric and phosphoric acid.
Table 1.-Selenium content, in parts per million, determined by various acid digestions and $X$-ray fluorescence

\begin{tabular}{|c|c|c|c|c|c|c|}
\hline \multirow{2}{*}{ Sample } & \multicolumn{5}{|c|}{$\begin{array}{l}\text { Acid mix used in digestion } \\
\text { (explained in text) }\end{array}$} & \multirow{2}{*}{ X-ray } \\
\hline & A & B & C & D & $\mathbf{E}$ & \\
\hline \multicolumn{7}{|l|}{ Jasperoid, Juab } \\
\hline County, Utah & 18.0 & 0.05 & 0.23 & 14.0 & 17.0 & 1.7 .0 \\
\hline Soil, 0 - to 7 -in. (0. to & & & & & & \\
\hline $\begin{array}{l}\text { 17.8-cm) depth, } \\
\text { Summit County, Utah }\end{array}$ & .40 & .05 & .60 & .30 & .40 & .8 \\
\hline \multicolumn{7}{|l|}{ Fe-Mn-W-rich spring } \\
\hline $\begin{array}{l}\text { deposit, Humboldt } \\
\text { County, Nev . . . . . . }\end{array}$ & 10 & .05 & .04 & .04 & .03 & .3 \\
\hline \multicolumn{7}{|l|}{ Porphyry copper, } \\
\hline Utah $\ldots \ldots \ldots$ & 5.0 & 3.70 & 8.60 & 4.60 & 6.1 .0 & 5.8 \\
\hline $\begin{array}{l}\text { Soil, 3- to } 10 \text {-in. (7.6- } \\
\text { to } 25.4-\mathrm{cm}) \text { depth, } \\
\text { Somerset Count y, } \\
\text { Maine . . . . . . . }\end{array}$ & .70 & .06 & .90 & .50 & .65 & 1..I. \\
\hline \multicolumn{7}{|l|}{ Soil, 6- to 18-in. (1.5.2. } \\
\hline $\begin{array}{l}\text { to } 45.7-\mathrm{cm}) \text { depth, } \\
\text { Davidson County, N.C. }\end{array}$ & .65 & Nil & 1.02 & .52 & .90 & .9 \\
\hline
\end{tabular}

The acid digestion without first roasting the sample either limits or prolongs the oxidation necessary for samples high in organic matter or sulfur content. The second and third samples of table 1 are examples.

The results obtained by these five different acid attacks are compared with results obtained by an X-ray fluorescence spectrographic method (table 1).

Good agreement with the X-ray method was also obtained on five of the six samples when equal volumes of $\mathrm{HNO}_{3}$ and $\mathrm{H}_{3} \mathrm{PO}_{4}$ (digestion $\mathrm{E}$ ) were used.

\section{Roasting of samples}

The decision to try roasting the samples with various sodium salts before the acid digestion with $\mathrm{HNO}_{3}$ and $\mathrm{H}_{3} \mathrm{PO}_{4}$ arose from dissatisfaction with direct acid digestion. Table 2 shows the results with four different roasting mixes:

1. Samples were roasted with an equal amount of $\mathrm{Na}_{2} \mathrm{CO}_{3}$.

2. Samples were roasted with an equal amount of 1 part $\mathrm{Na}_{2} \mathrm{CO}_{3}$ mixed with 1 part sodium peroxide.

3. Samples were roasted with an equal amount of 2 parts $\mathrm{Na}_{2} \mathrm{CO}_{3}$ mixed with 1 part $\mathrm{NaCl}$.

4. Samples were roasted with an equal amount of flux ( 6 parts $\mathrm{Na}_{2} \mathrm{CO}_{3}, 2$ parts $\mathrm{NaCl}$, and 1 part $\mathrm{NaClO}_{3}$ ).

The flux was used for roasting the sample for a variety of reasons: the resulting acid extract was cleaner, the oxidation and elimination of organic matter was more quantitative, smaller amounts of acid could be used for the acid digestion, and less time was needed for the acid digestion. The ratio of flux 1 to sample is $2: 1$ on a weight basis for sulfides and soils with organic matter.

A different roast is necessary for sulfur, because all the sulfur present must be oxidized before any selenium is oxidized (Wells, 1965). 
Table 2.-Selenium content, in parts per million, determined by roasting of samples with various sodium salts before acid digestion

\begin{tabular}{|c|c|c|c|c|c|}
\hline \multirow[t]{2}{*}{ Sample } & \multicolumn{4}{|c|}{$\begin{array}{l}\text { Sodium salt used in roasting } \\
\text { (explained in text) }\end{array}$} & \multirow[t]{2}{*}{ X-ray } \\
\hline & 1 & 2 & 3 & 4 & \\
\hline $\begin{array}{l}\text { Jasperoid, Juab } \\
\text { County, Utah ...... }\end{array}$ & 10.7 & 2.50 & 12.0 & 10.7 & 17.0 \\
\hline $\begin{array}{l}\text { Soil, 0- to 7-in. (0-to } \\
\text { 17.8-cm) depth, } \\
\text { Summit County, Utah } \\
\text { Fe-Mn-W-rich spring } \\
\text { deposit, Humboldt }\end{array}$ & .42 & .26 & .48 & .51 & .8 \\
\hline $\begin{array}{c}\text { County, Nev } \ldots \cdots \cdots \cdots \\
\text { Porphyry copper, }\end{array}$ & .51 & Nil & .32 & .32 & .3 \\
\hline $\begin{array}{l}\text { Utah } \\
\text { Soil, 3- to 10-in. (7.6- }\end{array}$ & 5.0 & 3.0 & 4.80 & 3.90 & 5.8 \\
\hline $\begin{array}{l}\text { to } 25.4 \text {-cm) depth, } \\
\text { Somerset County, Maine .... } \\
\text { Soil, 6- to 18-in. } \\
\text { (15.2- to } 45.7-\mathrm{cm}) \\
\text { depth, Davidson County, N.C. }\end{array}$ & .70 & .25 & .65 & .59 & 1.1 \\
\hline
\end{tabular}

\section{PRECISION AND ACCURACY}

An analytical cross reference sample was available in National Bureau of Standards plastic clay 98, which was reported as having $1.37 \mathrm{p} / \mathrm{m}$ selenium by Wells (1965), 1.2 $\mathrm{p} / \mathrm{m}$ selenium by J. S. Wahlberg (unpub. data, 1974), and 1.04 $\mathrm{p} / \mathrm{m}$ selenium as a mean value of 10 determinations by the proposed method.

The relative standard deviations obtained by this method on replicate determinations range from 4.8 to 13.8 percent in five different types of samples, with 10 determinations on each sample (table 3).

The agreement of the selenium content obtained by this method with that obtained by J. S. Wahlberg's X-ray fluorescence method is satisfactory (tables 4,5$)$.

The selenium content can be determined by this method in samples containing as much as 84 percent lead, 95 percent copper, 62 percent iron, 19 percent manganese, 20 percent organic matter, or 95 percent sulfur, as observed in the data on very diverse materials (tables $3,4,5$ ).
Table 4.-Selenium in cement copper from eight different copper leach plants in Arizona

\begin{tabular}{|c|c|c|}
\hline \multirow[b]{2}{*}{ Sample } & \multicolumn{2}{|c|}{ Selenium content (parts per million) } \\
\hline & By proposed method & $\begin{array}{c}\text { By X-ray fluorescence } \\
\text { method }\end{array}$ \\
\hline$\ldots \ldots \ldots$ & 10.7 & 10.0 \\
\hline $2 \ldots \ldots \ldots \ldots$ & 10.7 & 10.0 \\
\hline $3 \ldots \ldots \ldots \ldots$ & 3.5 & 3.0 \\
\hline $4 \ldots \ldots \ldots \ldots \ldots$ & 10.0 & 9.0 \\
\hline $5 \ldots \ldots \ldots \ldots$ & 19.1 & 17.0 \\
\hline $6 \ldots \ldots \ldots$ & 10.0 & 8.0 \\
\hline $7 \ldots \ldots \ldots \ldots$ & 10.7 & 8.0 \\
\hline $8 \ldots \ldots \ldots \ldots$ & 12.9 & 10.0 \\
\hline
\end{tabular}

Table 5.-Selenium in sulfide minerals and sulfur

\begin{tabular}{cccc}
\hline & \multicolumn{3}{c}{ Selenium content (parts per million) } \\
\cline { 2 - 4 } Sample type & $\begin{array}{c}\text { Roasting } \\
\text { procedure }\end{array}$ & $\begin{array}{c}\text { By proposed } \\
\text { method }\end{array}$ & $\begin{array}{c}\text { By X-ray } \\
\text { fluorescence method }\end{array}$ \\
\hline Chalcopyrite ..... & B & 305 & 280 \\
Galena ........ & B & 19.5 & 20 \\
Pyrrhotite ....... & B & 100 & 70 \\
Pyrite ......... & B & 159 & 130 \\
Tetrahedrite ...... & B & 2 & 4 \\
Sulfur .......... & C & 20 & 20.5 \\
\hline
\end{tabular}

\section{DISCUSSION}

The acid digestion alone is not adequate for samples with high contents of iron, organic matter, or sulfur.

The samples were roasted with a flux to accelerate the decomposition of organic matter and to convert the selenium present to sodium selenite or sodium selenate. The sodium salts of selenium are readily soluble in the mixed acid. The amount of sodium salts used to roast the sample must be kept to a minimum. Because of the small size of the sample used in trace analysis, the concern here is with excess flux, which may create interference such as high ionic concentrations and, on

Table 3.-Replicate determinations of selenium

[Values based on 10 determinations per sample]

\begin{tabular}{|c|c|c|c|c|c|c|}
\hline \multirow{2}{*}{ Sample } & \multirow{2}{*}{$\begin{array}{c}\text { Roasting } \\
\text { procedure }\end{array}$} & High & Low & Mean & \multirow{2}{*}{$\begin{array}{l}\text { Standard } \\
\text { deviation }\end{array}$} & \multirow{2}{*}{$\begin{array}{c}\text { Relative standard } \\
\text { deviation (percent) }\end{array}$} \\
\hline & & \multicolumn{3}{|c|}{ Parts per million } & & \\
\hline \multicolumn{7}{|l|}{ Plastic clay 98 , U.S. } \\
\hline Natl. Bur. Standards & B & 1.15 & 0.95 & 1.04 & 0.08 & 7.7 \\
\hline \multicolumn{7}{|l|}{ Sulfur, Cortez } \\
\hline Mountains, Nev & C & 17.2 & 13.2 & 15.2 & 1.5 & 9.9 \\
\hline \multicolumn{7}{|l|}{ Sulfide mineral } \\
\hline (galena) .... & B & 18.0 & 15.4 & 16.6 & .8 & 4.8 \\
\hline \multicolumn{7}{|l|}{ Pierre Shale, } \\
\hline Gregory, S. Dak & B & 1.35 & 1.10 & 1.28 & .10 & 7.8 \\
\hline \multicolumn{7}{|l|}{ Mn and Fe oxide cement, } \\
\hline Somerset County, Maine & B & .72 & .51 & .58 & .08 & 13.8 \\
\hline
\end{tabular}


neutralization, unnecessary precipitates that could influence the precipitation of selenium (Gorsuch, 1970).

The need for the double roasting of sulfur samples is evidenced by the fact that selenium is lost and sulfur is not completely oxidized when the roast for soils is used. The fluorescence of the solution fades fast if the sulfur is not completely oxidized.

The decision to use the flux $\left(\mathrm{Na}_{2} \mathrm{CO}_{3}, \mathrm{NaCl}\right.$, and $\left.\mathrm{NaClO}_{3}\right)$ was prompted by the following:

1. Obvious inadequacy of the acid digestion (table 1).

2. Cleanness of the acid extract (free of turbidity) after use of flux.

3. Initial attack of the sample by the $\mathrm{NaClO}_{3}$ which destroys most if not all of the organic matter.

4. Elimination of possible lattice concealment of selenium.

5. Conversion of the selenium present to selenite and selenate.

6. Reduction of the volume of mixed acids to permit a final volume of sample solution of not more than $50 \mathrm{ml}$.

The short extraction times and washing of the extracted piazselenol with $0.1 \mathrm{~N} \mathrm{HCl}$ are used to overcome the possibility of side reactions with the DAN solution. The side reactions could be protonated piazselenol or oxygen in place of selenium in the piazselenol molecule (Wilkie and Young, 1.970).

The use of subdued light during and after the addition of the DAN solution prevents the formation of dimers and decomposition of the DAN (Wilkie and Young, 1970).

Most of the glassware used can be cleaned with soap and water. The separatory funnels should be cleaned with an acid cleaning solution.

\section{CONCLUSION}

The sensitivity of this method permits the determination of selenium within range of the estimated crustal abundance for the element. Thus, the analytical procedure proposed here should provide data suitable for the geochemical study of selenium in geologic materials.

\section{REFERENCES CITED}

Gorsuch, T. T., 1970, Oxidative fusion and other methods, chapter 6 in The destruction of organic matter [1st ed.]: New York, Pergamon Press, p. 40-43.

Hemsted, W. R. T., Sina, M., and Cekicer, S., 1972, A simplified method for the determination of selenium in soils and sediments: Analyst, v. 97, p. 383-387.

Levesque, M., and Vendette, E. D., 1971, Selenium determination in soil and plant materials: Canadian Jour. Soil Sci., v. 51, p. 85-93.

Parker, C. A., and Harvey, L. G., 1962, Luminescence of some piazselenols-A new fluorimetric reagent for selenium: Analyst, v. 87 , p. $558-565$.

Parker, R. L., 1967, Composition of the Earth's crust, in Data of geochemistry [6th ed.]: U.S. Geol. Survey Prof. Paper 440-D, p. D1-D19.

Severne, B. C., and Brooks, R. R., 1972, Rapid determination of selenium and tellurium by atomic-absorption spectrophotometry: Talanta, v. 19, p. 1467-1470.

Watkinson, J. H., 1967, Analytical methods for selenium in biological material, chapter 6 in Muth, O. H., Oldfield, J. E., and Weswig, P. H., eds, Symposium, Selenium in biomedicine: Westport, Conn., AAVI Publishing Co., Inc., p. 97-127.

Wells, N., 1965, Selenium content of soil-forming rocks: New Zealand Jour. Geology and Gcophysics, v. 10, p. 198-208.

Wilkie, J. B., and Young, Mamie, 1970, Improvement in the 2,3-diaminonaphthalene reagent for microfluorescent determination of selenium in biological materials: Jour. Agr. and Food Chemistry, v. 18 , no. 5 , p. 944- 945 . 
0 


\title{
TIME OF TRAVEL AND DYE DOSAGE FOR AN IRRIGATION CANAL SYSTEM NEAR DUCHESNE, UTAH
}

\author{
By D. B. Adams, Salt Lake City, Utah
}

Work done in cooperation with the Utah Department of Natural Resources

\begin{abstract}
A time-of-travel study was conducted in connection with seepage studies of an irrigation canal system near Duchesne, Utah. Mean velocities for the canal reaches range from 1.32 to $1.88 \mathrm{ft} / \mathrm{s}$. Dye concentrations at the ends of the study reaches were greater than expected, indicating that the equation used for calculation of dosage required modification. Regression analysis of the data indicate that the dye-dosage equation for the system studied should be

$$
\forall_{d}=2.49 \times 10^{-4}\left(\frac{Q_{m} L}{V}\right)^{0.70} C_{p}
$$
\end{abstract}

The time-of-travel study covered by this report involves a single time-of-travel measurement for each of five reaches of two canals near Duchesne, Utah (fig. 1). Both canals are used entirely for irrigation. The study was conducted to aid in a detailed secpage study of the canal system that was being carried out in cooperation with the Utah Department of Natural Resources.

The study was somewhat different in purpose and in type of system than the usual time-of-travel study; it was made to determine accurate stream velocities. The stream velocities were required as a basis for adjustment of discharge measurements previously made to evaluate channel storage in the canals. Most time-of-travel studies are undertaken to determine the traveltime of contaminants. The canals are a losing system (decreasing discharge) not a gaining one (increasing discharge) as are most river-tributary systems. The canals in the system are uniform in shape and generally have uniform, steady flow, whereas the river-tributary system generally is nonuniform in shape and has nonuniform, unsteady flow. The canal study reaches, generally $6-10 \mathrm{mi}$ long with sampling sites $2 \mathrm{mi}$ apart, are shorter than the study reaches of the usual river-tributary system.

The study was conducted in accordance with the U.S. Geological Survey methods outlined by F. A. Kilpatrick, L. A. Martens, and J. F. Wilson, Jr. (written comm., 1970). Fluorometer use was as outlined by Wilson (1968). Figure 1 shows dye-injection sampling sites.

\section{GREY MOUNTAIN-PLEASANT VALLEY CANAL}

The Grey Mountain-Pleasant Valley Canal (fig. 1), which is approximately $30 \mathrm{mi}$ long, heads $4 \mathrm{mi}$ below Duchesne on the right bank of the Duchesne River. The canal extends east along the river to a division point at approximately mile 7 . The section from the head to the division and the lower section beyond the division are known collectively as the Grey Mountain Canal. The lower section beyond the division supplies water to irrigate land adjacent to the river. The upper section beyond the division carries irrigation water into Pleasant Valley and is known as the Pleasant Valley Canal.

The canal is unlined and is generally rectangular in cross section. Manning's resistance coefficient, $n$, has a value of 0.026 and the slope is approximately 0.0003 , excluding drop structures in the Grey Mountain Canal. The maximum discharge at the head is approximately $300 \mathrm{ft}^{3} / \mathrm{s}$.

\section{ROCKY POINT CANAL}

The Rocky Point Canal (fig. 1), which is approximately 18 mi long, heads $4 \mathrm{mi}$ above Duchesne on the left bank of the Duchesne River. The canal extends south to Duchesne and then east along the bank of the river. At approximately mile 5 the canal divides into upper and lower segments.

The canal is unlined and is generally rectangular to trapezoidal in cross section. The $n$ value is 0.030 and the slope is approximately 0.0005 . The maximum discharge at the head is approximately $50 \mathrm{ft}^{3} / \mathrm{s}$.

\section{FIELD PROCEDURE}

The Grey Mountain-Pleasant Valley Canal was divided into four reaches for the time-of-travel study. The Rocky Point Canal consisted of a single reach. The dye studies were conducted September 25-29, 1972. Study reaches were ordered so that the last downstream reach of the Grey MountainPleasant Valley Canal was injected with dye first to prevent contamination of upstream reaches with dye from previous injections. Rhodamine WT 20-percent dye solution was injected at the head of each study reach. The volume of dye for each injection was determined by using the dosage equation given by Kilpatrick (1970). Discharge was measured at each injection site. (See table 1.) 
Figure 1.-Dye-injection and sampling sites on the Grey MountainPleasant Valley Canal.

\section{RESULTS}

\section{Time-of-travel measurements}

Traveltime-distance curves for the four dye-injected reaches of the Grey Mountain-Pleasant Valley Canal are shown in figure 2. These data and those for the Rocky Point Canal were interpreted by using peak concentration as the indicator for average time between sampling points. The use of peak concentration rather than weighted-average (centroid) concentration to determine average velocity was based on the small skewness of the time-concentration curves (fig. 4), and resulted in nearly identical peak and centroid traveltimes, and

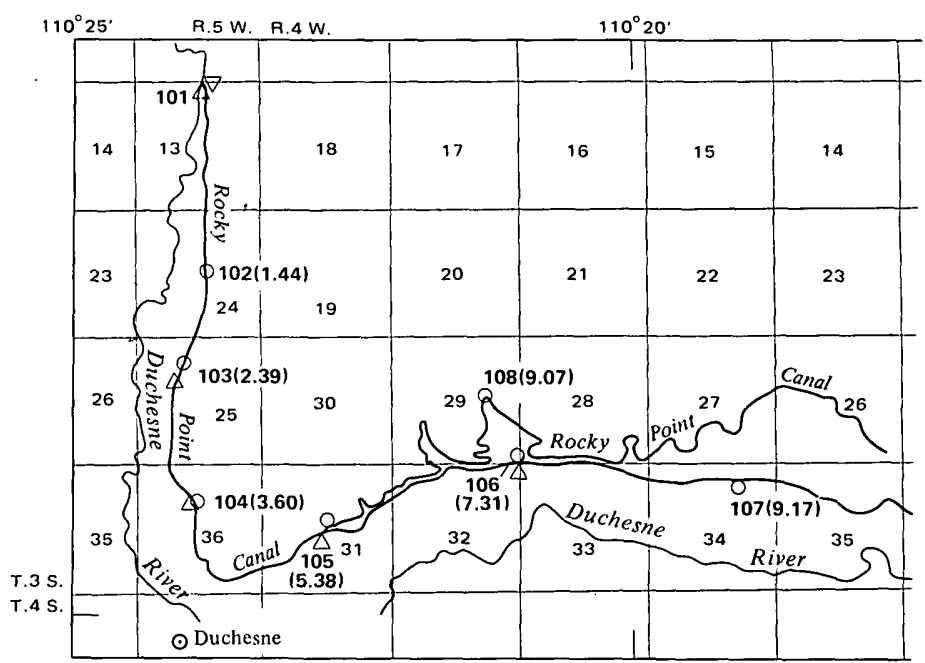

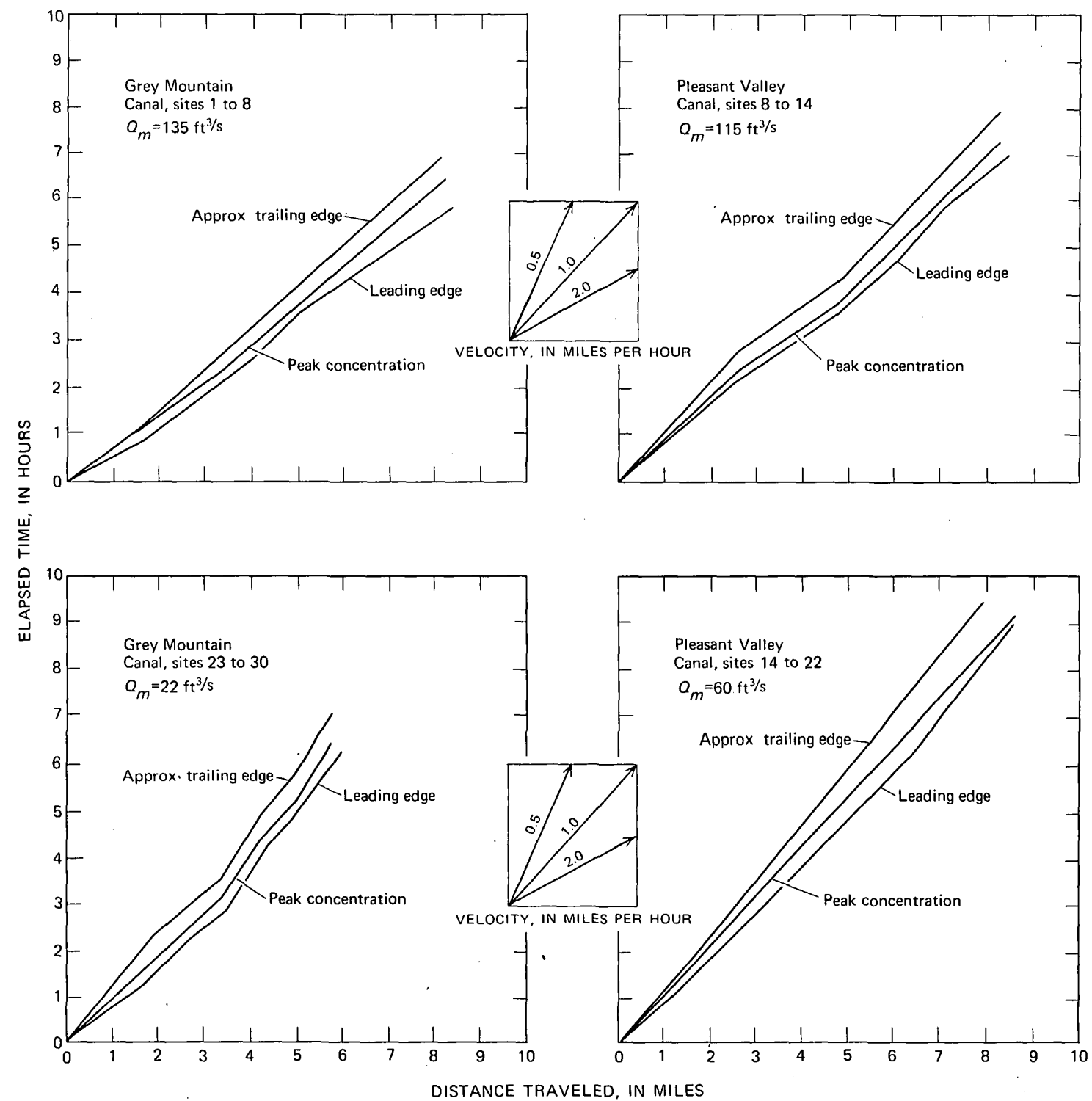

Figure 2.-Traveltime-distance curves for dye-injected reaches in the Grey Mountain-Pleasant Valley Canal. 
provided greater ease and directness in determination of time of peak concentration. The resultant velocities are shown in table 1 .

Table 1.-Data for dye-dosage equation and rêsults of time-of-travel measurements

\begin{tabular}{|c|c|c|c|c|c|}
\hline \multirow[b]{2}{*}{ Reach } & \multicolumn{2}{|c|}{ Grey Mountain } & \multicolumn{2}{|c|}{ Pleasant Valley } & \multirow{2}{*}{$\begin{array}{c}\text { Rocky Poin } \\
101-107\end{array}$} \\
\hline & $1-8$ & $23-30$ & $8-14$ & $14-22$ & \\
\hline Length of reach . . . . . mi & 7.39 & 5.76 & 8.27 & 7.92 & 9.17 \\
\hline $\begin{array}{l}\text { Maximum discharge } \ldots \mathrm{ft}^{3} / \mathrm{s} \ldots \\
\text { Mean velocity: }\end{array}$ & 135 & 22 . & 115 & 60 & 27 \\
\hline $\begin{array}{l}\text { Used in dosage } \\
\text { calculations }\end{array}$ & 2.89 & 2.38 & 2.55 & 1.64 & 1.81 \\
\hline $\begin{array}{l}\text { Measured at } \\
\text { injection sitc . . . . ft/s } \\
\text { of reach from }\end{array}$ & 2.49 & 2.13 & 1.91 & 1.55 & 1.47 \\
\hline $\begin{array}{l}\text { time-of-travel } \\
\text { measurements } \ldots \mathrm{ft} / \mathrm{s}\end{array}$ & 1.88 & 1.32 & 1.68 & 1.33 & 1.41 \\
\hline
\end{tabular}

' Based on previous discharge measurements.

The traveltime-distance curve for the dye-injected reach in the Rocky Point Canal, together with the cumulative curve for the Grey Mountain-Pleasant Valley Canal, is shown in figure 3. The latter curves shows a significant change in slope at about mile 12.2 (site 10). Mean velocity for the reach from site 1 to site 10, determined from figure 3 , was about 1.23 $\mathrm{mi} / \mathrm{h}$ or $1.80 \mathrm{ft} / \mathrm{s}$; from site 10 to site 22 , mean velocity was about $1.0 \mathrm{mi} / \mathrm{h}$ or $1.47 \mathrm{ft} / \mathrm{s}$. The constant velocity from site 10 to site 22 , with a decreasing stage and discharge, indicates that there is probably little change in velocity with normal changes in stage in the Grey Mountain-Pleasant Valley Canal.

Mean velocity of the Rocky Point Canal was about 0.97 $\mathrm{mi} / \mathrm{h}$ or $1.41 \mathrm{ft} / \mathrm{s}$. The time-of-travel data are reported only for sites 101-107. The data for site 108 were used in the regression analysis for the new equation and are shown in figure 5. The time of travel to site 108 is not considered representative of the section because of much lower than usual discharge.
Typical time-concentration curves are shown in figure 4 . The complete set of time-concentration curves are not presented because determinations of dispersion characteristics and discharge were not the primary purposes of the study.

\section{Dye-dosage equation}

The dosage equation for the Rhodamine WT 20-percent dye solution used, as given by Kilpatrick (1970), is

$$
\forall_{d}=3.4 \times 10^{-4}\left(\frac{Q_{m} L}{V}\right)^{0.93} C_{p}
$$

where $\forall_{d}=$ volume of dye, in liters,

$Q_{m}=$ maximum discharge in the reach, in cubic feet per second,

$L=$ distance to the sampling point of the desired concentration, in miles,

$V=$ mean velocity (best estimate), in feet per second, and

$C_{p}=$ peak concentration desired, in micrograms per liter.

Using $10 \mu \mathrm{g} / \mathrm{l}$ as the maximum desired concentration at the end of the study reach for a particular injection, the amount of dye needed was calculated from the above equation. The discharge $\left(Q_{m}\right)$ was measured at the injection site, the length of the reach $(L)$ was determined from maps, and the estimated mean velocity $(V)$ (table 1 ) was determined from the mean of several previous discharge measurements made at preselected intervals along the reach. The use of this velocity estimate should have given a conservative estimate of the amount of dye needed, as velocities from discharge measurements are generally higher than those determined from time-of-travel studies.
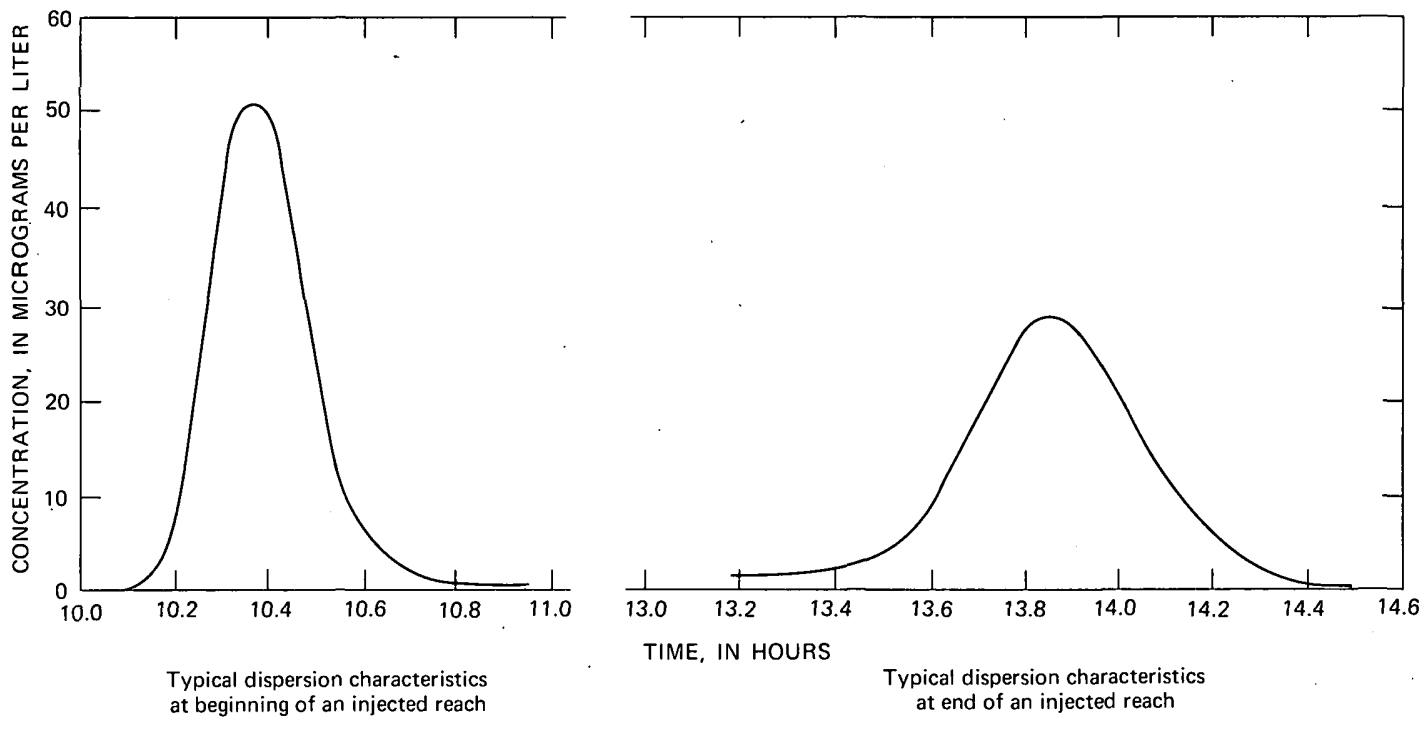

Figure-4.- Typical time-concentration curves. 
The dye concentrations at the ends of the study reaches that resulted from the use of the above equation were consistently higher than expected. These results suggested that either the mean velocities used in the initial equation were too low, that the constants of the equation were not valid for this system, or that the form of the equation was not valid.

A check of velocities used in the calculation of dye dosage showed that they were higher than those observed from the time-of-travel measurements (see table 1). The other alternatives were then explored. Using a step-backward regression method for several equation forms, it was determined that modification of the constants of the original equation gave the best result and that the equation for this system should be

$$
\nvdash_{d}=2.49 \times 10^{-4}\left(\frac{Q_{m} L}{V}\right)^{0.70} C_{p}
$$

(See fig. 5.) The correlation coefficient for this equation is 0.98 and the standard error of estimate is $0.066 \log$ units or \pm 15 percent.

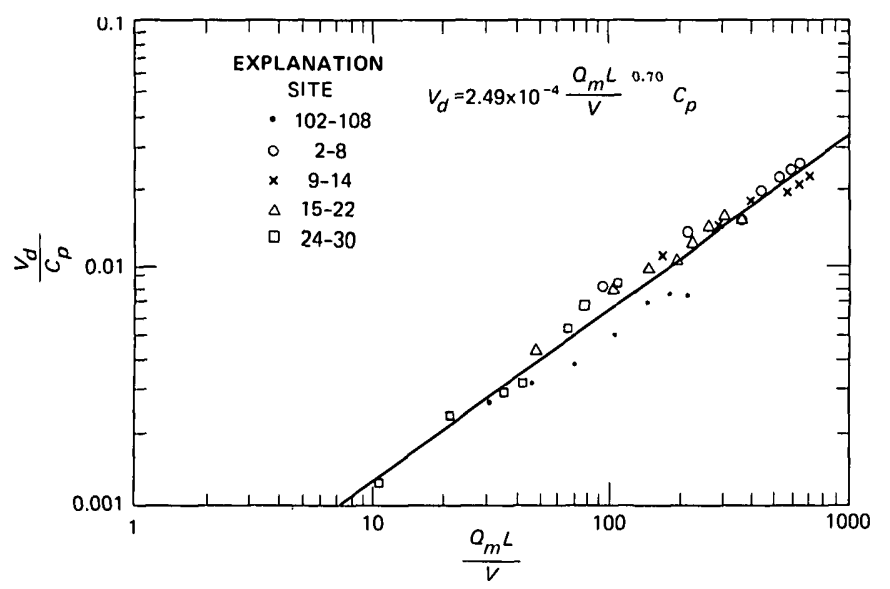

Figure 5.-Relation of $\frac{Q_{m} L}{V}$ to $\frac{V_{d}}{C_{p}}$ for the canal system.

The data cover only a narrow range of values for the equation parameters, and extrapolation of the curve beyond the range of the data therefore may not be valid. It should be noted that the ploted data from each injection fall along lines having discrete slopes and that separate equations for each reach could be developed. The limited data do not justify this, and the equation for the overall trend is the only one presented.

\section{CONCLUSIONS}

The results of the time-of-travel study are relatively consistent for this system and are adequate for the adjustment of discharge measurements for the seepage study. Further timeof-travel measurements for varying stages for the entire system are thought to be unnecessary because relatively constant velocities were observed at varying stages for sites 10-22 of the Pleasant Valley Canal.

The dye-dosage equation developed for the canal system in this study is valid only for the Rhodamine WT 20-percent dye used and for the ranges of the parameters found. Analysis of the data collected during the study and examination of alternative explanations for the greater-than-expected dye concentrations observed at the ends of the study reaches suggest that the constants in the equation are dependent upon the physical characteristics of the particular system to be injected. The original equation used in the study required modification. Factors that probably contributed to the need for modification include water loss from the canals (the system is a losing rather than a gaining one), channel shape and uniformity, and flow conditions.

With the increasing need for time-of-travel data and with restrictions on allowable concentrations of tracers, time-oftravel studies covering a large range of parameter values for several different types of systems are needed. Such studies would provide a greater understanding of the relation between dye dispersion and physical characteristics of the system and provide an improved basis for calculating optimum dye dosage in future studies.

\section{REFERENCES CITED}

Kilpatrick, F. A., 1970, Dosage requirements for slug injections of Rhodamine BA and WT dyes, in Geological Survey research 1970: U.S. Geol. Survey Prof. Paper 700-B, p. B250-B253.

Wilson, J. F., 1968, Fluorometeric procedures for dye tracing: U.S. Geol. Survey Techniques of Water Resources Inv., book 3, chap. A]. 2, 31. p. 



\title{
GENERALIZATION OF STREAM TRAVEL RATES AND DISPERSION CHARACTERISTICS FROM TIME-OF-TRAVEL MEASUREMENTS
}

\author{
BY CHARLES W. BONING, Washington, D. C.
}

\begin{abstract}
Prediction of travel rates of water in streams is important for pollution control and for warning systems where contaminant spillage is possible. A method of estimating traveltime and dispersion of solutes in streams where such data are not available is provided in this report. Generalized relations for travel rates and dispersion indices as functions of stream-channel and discharge characteristics are developed using available time-of-travel data and the multiple-regression technique.
\end{abstract}

The U.S. Geological Survey, in addition to operating gaging stations throughout the United States, conducts many other investigations supplementing or complementing the definition of streamflow in rivers and streams. The investigations complementing stream discharge data include studies of time of travel and dispersion of solutes in streams. This information is of great importance when pollution or contamination of streams is a likely occurrence or when a water course is used to transport municipal or industrial wastes. Studies prior to the use of soluble tracers consisted primarily of computations of travel rates from average velocities at stream cross sections or from the timing of surface floats or flood waves (Searcy and Davis, 1961.; Steacy, 1961). These are indirect methods of measuring travel rates of water; a more direct method is the measurement of movement of a material soluble with or contained in the water.

The Geological Survey has, for the most part, used fluorescent tracers although several studies, usually in cooperation with the Atomic Energy Commission, utilized radioactive tracers (Simpson and others, 1959). Techniques involved in the use of dye in time-of-travel studies are described by Wilson (1.969), Buchanan (1964), and F. A. Kilpatrick (written commun., 1970). The general procedure is to inject a known quantity of water-soluble dye into a stream and to observe the movement and dispersion of this dye by sampling and fluorometric testing. Many studies are made only to determine travel rates in streams. Others (Taylor, 1970; Stewart, 1967) involved data collection sufficient for dispersion analysis. Some studies are made solely for this purpose (Yotsukura and others, 1970).

Time-of-travel data have been used primarily for analyses of streams where these data were collected. A method of rapidly estimating traveltime or dispersion is seriously needed for pollution control or warning systems on streams where such data are not available. This investigation uses the results of many time-of-travel measurements to develop equations for estimating travel rates and dispersion. These equations were developed using the linear regression model, where either the stream travel rate or the dispersion index is considered the dependent variable and channel or discharge characteristics are the independent variables.

Data in this report are given in English units of measure and can be converted to the International System as shown in table 1 .

\section{DATA}

Time-of-travel data have been collected on more than 300 streams in the United States and involve more than 12,000 stream miles. Most streams were measured for time of travel in several reaches and for different discharges. Of approximately 1,500 individual measurements of this type, 873 have adequate supplementary channel and discharge information for

Table 1.-Factors for converting English units of measure, as used in this report, to the International System (SI)

\begin{tabular}{|c|c|c|c|c|c|}
\hline Symbol & Unit & & Multiply by & To obtain & \\
\hline \multirow{2}{*}{$c U \ldots \ldots \ldots$} & micrograms per liter & $\mu \mathrm{g} \cdot \mathrm{l}^{-1}$ & \multirow{2}{*}{0.0625} & micrograms per liter & \multirow{2}{*}{$\left(\frac{\mu \mathrm{g} \cdot \mathrm{T}}{\mathrm{kg} \cdot \mathrm{m}^{-3} \cdot \mathrm{s}}\right)$} \\
\hline & pound per cubic foot per second & $\left(\mathrm{lb} \cdot \mathrm{ft}^{-3} \cdot \mathrm{s}\right.$ & & kilogram per cubic meter per second & \\
\hline$X$ & miles ( $\mathrm{mi})$. . & & 1.609 & kilometers $(\mathrm{km})$. & \\
\hline & cubic feet per second $\left(\mathrm{ft}^{3} / \mathrm{s}\right)$ & & .02832 & cubic meters per second $\left(\mathrm{m}^{3} / \mathrm{s}\right)$. & \\
\hline & acre-fect (acre-ft) & & $1,233.5$ & cubic meters $\left(\mathrm{m}^{3}\right)$. & \\
\hline$P$. & feet per second $(\mathrm{ft} / \mathrm{s})$ & & .3048 & meters per second $(\mathrm{m} / \mathrm{s})$ & \\
\hline & pounds (lb) & & .4536 & kilograms (kg). & \\
\hline
\end{tabular}


use in this analysis. These data were provided for streams throughout the United States and represent a variety of stream size, slope, and discharge.

\section{TIME-OF-TRAVEL AND DISPERSION CHARACTERISTICS}

The time-of-travel and dispersion characteristics studied for this report were those that are commonly obtained in field time-of-travel studies. Their values would be essential in a warning system should a contaminant spillage occur in a given stream. This report defines two indices of stream velocity and two indices of dispersion.

\section{Rate-of-travel indices}

When a dye or other soluble material is injected into a stream that is flowing with a steady discharge, longitudinal dispersion causes the first traces of the dye to travel faster than the most highly concentrated part of the dispersed dye cloud. In this report the initial trace of dye is called the leading edge of the dye cloud, and the maximum concentration is termed the peak of the dye cloud or, simply, the peak. The arrivals of both the leading edge and the peak at downstream locations are of utmost concern to water users of a stream into which a contaminant may be spilled.

The indices of leading-edge velocity and peak velocity were used rather than traveltimes to more easily utilize the results of investigations where there were multiple sampling points downstream from an injection. These indices are expressed in feet per second and given the symbols $V L$ (leading edge) and $V P$ (peak).

\section{Dispersion indices}

As a soluble material moves with a flowing stream, it is dispersed vertically, laterally, and longitudinally. Vertical and lateral dispersion are completed readily; longitudinal dispersion continues indefinitely. Longitudinal dispersion is often described by a longitudinal dispersion coefficient, with which the degree of dispersion can be estimated (Godfrey and Frederick, 1963).

Rather than using a dispersion coefficient as an index, as described by Godfrey and Frederick, this study uses unit concentration and the length of time required for the dye cloud to pass monitoring points downstream as indices of dispersion. Unit concentrations are computed by adjusting observed concentration data for dye loss, for differing discharge, and for differing quantities of injected dye. It provides a means of comparing the results from different streams and different tests, and isolates the role longitudinal dispersion plays in attenuating concentrations with time or distance downstream. Unit concentration is symbolized by $C U$ and expressed as the concentration in micrograms per liter resulting from the injection of $1 \mathrm{lb}$ of dye in each cubic foot per second of flow. Duration, symbolized by $D$, is the length of time for the dye cloud to pass a given point. It is expressed in hours and is defined by measuring the time from the leading edge of the dye cloud to the time on the trailing edge where the concentration is 10 percent of the peak concentration. This concentration was chosen from inspection of many time-concentration curves, noting that most studies in which concentrations were collected after the peak had data sufficient to define the curve to this point. The dispersive characteristics of many streams caused the time concentration curves to have extremely long tails, making the definition of a point of lesser concentration extremely difficult.

\section{DISCHARGE AND CHANNEL CHARACTERISTICS}

The immediate need for estimates of travel rate and dispersion dictates that the numerical values for variables used in a prediction equation be quickly and easily estimated. Descriptions of the channel or discharge characteristics that were significant independent variables in the regression analyses follow.

\section{Discharge}

Discharge has been empirically proven to be related to velocity of flow; Manning's equation (Daugherty and Ingersoll, 1954) indicates that for a given slope and a wide channel, velocity increases with discharge to the 0.4 power. For the various reaches discharge was determined by current-meter measurement, from station rating curves, or by an interpolation or estimation from known upstream or downstream discharges. The discharge used is that which existed at the sampling point of the subreach; this generalization was not thought to introduce significant errors in the analysis. Reaches which had flow increases greater than 10 percent during the measurement were eliminated from the analysis. The symbol $Q$ is used in this report for discharge in cubic feet per second.

\section{Flow duration}

Flow duration in this report is defined as the percentage of time the daily flow is equaled or exceeded. The term is dimensionless. This variable is symbolized by $F$ and was determined only where adequate records are available.

\section{Channel slope}

The slope of a channel has been used as a major component in many flow equations. For this report the slope index used is the dimensionless term of feet per foot and is given the symbol $S$. The numerical values assigned to this variable have a large range in accuracy; the methods for their determination ranged from accurate survey data to estimation from topographic maps.

\section{Channel storage}

The storage used in this study refers to artificial impoundment of water and is used only in the analyses for lock and 
dam reaches. The dimensions of this variable symbolized by $S t$ are in acre-feet.

\section{Length}

The length of the study reach is not directly used as a variable in the velocity regression analyses but is a significant variable in defining the amount of dispersion that occurs for an injected solution. The lengths symbolically identified by $L$ are miles from injection to the sampling point and were determined from known river mileage, map measurement, or other river surveys. Individual reach lengths, also expressed in miles, are identified as $X$.

\section{STREAM REACHES}

The travel rate of water and the dispersive characteristics of streams can be expected to vary with channel configuration, slope, and discharge. The reaches used in this study were categorized as pool and riffle, channel controlled, or lock and dam reaches.

\section{Pool and riffle reaches}

Pool and riffle reaches are characterized by a series of pools with relatively low velocity separated by bars or riffles over which the stream flows more rapidly. Water-surface slope may vary from minimal in the pools to steep at the riffles. Because of inconsistent pool lengths for this condition, the channel slope is not as representative of the local hydraulic gradient as in channel-controlled streams. Channel configuration also varies with length on this type of reach. Discharge in these reaches ranged from 3 to $4,000 \mathrm{ft}^{3} / \mathrm{s}$. Duration frequencies ranged from 7 to 99 percent and slopes of the reaches ranged from 0.00012 to $0.0057 \mathrm{ft} / \mathrm{ft}$.

\section{Channel-controlled reaches}

In channel-controlled streams the stage for a given discharge is governed by the slope and roughness of the channel over a considerable distance rather than in a short distance such as exists with pool and riffle streams (Corbett and others, 1945). The reaches with channel control that are used in this analysis are characterized by fairly uniform channels. The streams in the channel-control category were generally larger than streams in other categories and included the Mississippi and lower Missouri, with data for discharges as high as 241,000 $\mathrm{ft}^{3} / \mathrm{s}$. Average discharge was $14,200 \mathrm{ft}^{3} / \mathrm{s}$. The slopes in these reaches averaged $0.00041 \mathrm{ft} / \mathrm{ft}$ and ranged from 0.000016 to $0.0027 \mathrm{ft} / \mathrm{ft}$. Duration frequency of discharge ranged from 2 to 99 percent.

\section{Reaches with locks or dams}

In these reaches the flow is controlled to a varying extent by a structure located within the reach. For this study the retardation of flow is expressed by the volume of water stored by these structures. Reaches where storage is not known were omitted from the analysis.

The range of storage for streams in this category was from 6 to 6,560 acre-ft. Discharge ranged from 29 to $8,640 \mathrm{ft}^{3} / \mathrm{s}$. For this analysis the length of the reach was found to be a significant characteristic. This significance is attributed to an assumed strong relationship between total length of reach and the length of reach where storage existed.

Data suitable for dispersion analysis are contained in only 11 . reaches in this category. No regressions with this small sample were made.

\section{ANALYTICAL METHODS}

Analytical studies and data reports (Leopold and Maddock, 1953; Stall and Fok, 1968; Thomas and Benson, 1970) have shown that the logarithms of discharge characteristics are linearly related to the logarithms of many channel and basin characteristics. Graphic plots in these and other studies confirmed the general applicability of the linear regression model for logarithms of the variables. Therefore, logarithmic transformation of all variables was done before calculations were attempted.

Statistical multiple-regression analyses were used to develop, for each reach category, relations between rate of travel and dispersion characteristics (dependent variables) and channel and discharge characteristics (independent variables). The use of the multiple-regression technique provides a mathematical equation of the relation between a single dependent variable and the independent variables. Also provided by the multipleregression analysis is a measure of the accuracy of the defined relation. This measure, called the standard error of estimate, is the range of error within which the values estimated by the regression equation fall for two-thirds of the samples. The values estimated by the equation are within twice that range for 95 percent of the samples.

The statistical significance of each independent variable is measured by its probability of effectiveness or significance in the regression equation. Although other independent variables were used in analysis, only those that had a 95-percent probability of effectiveness were retained in the equations.

\section{RESULTS}

The following equations relating the indices of travel rate and dispersion to channel and flow characteristics were provided by the multiple-regression analyses. Also shown are the standard errors of estimate in logarithmic units and in percentage for each equation.

\section{Equations}

$\frac{\text { Standard error }}{\text { Log Percentage }}$

Pool and riffle reaches:

$V P=0.38 Q^{0.40} S^{0.20} \ldots \ldots \ldots \ldots \ldots .17$

$V L=0.60 Q^{0.37} S^{0.21} \ldots \ldots \ldots \ldots \ldots \ldots . .18$ 
Equations

Pool and riffle reaches--Continued

$$
\begin{aligned}
& C U=3160 L^{-0.55} Q^{0.39} S^{0.28} \ldots \ldots \ldots \ldots .20 \\
& D=3.40 L^{+0.56} Q^{-0.40} S^{-0.27} \ldots \ldots \ldots \ldots .20 \\
& \text { Channel-controlled reaches: } \\
& V P=2.69 Q^{0.26} S^{0.28} \ldots \ldots \ldots \ldots \ldots \ldots .12 \\
& V L=2.86 Q^{0.27} S^{0.28} \ldots \ldots \ldots \ldots \ldots \ldots .12 \\
& C U=139,000 L^{-0.88} Q^{0.27} S^{0.51} \ldots \ldots \ldots \ldots .20 \\
& D=0.062 L^{0.89} Q^{-0.28} S^{-0.53} \ldots \ldots \ldots \ldots .19 \\
& \text { Lock and dam reaches: } \\
& V P=0.056 Q^{0.50} X^{0.32} S t^{-0.19} \ldots \ldots \ldots \ldots .21 \\
& V L=0.077 Q^{0.50} X^{0.31} S t^{-0.22} \ldots \ldots \ldots \ldots .20
\end{aligned}
$$

Standard error

Percentage

The above equations for velocity can also be used to estimate, for a specified stream length, the traveltime of a soluble contaminant. This estimate may be obtained by

$$
T P=1.467 L / V P
$$

where TP is traveltime of the peak concentration, in hours; $L$ is reach length, in miles; and $V P$ is the velocity estimated by the regression equation, in feet per second. Time of the leading edge of the dye or contaminant would be estimated similarily. The equations for unit concentration are applicable only for distances large enough for vertical and lateral dispersion to have occurred. A method of estimating this distance is presented by F. A. Kilpatrick (written commun., 1970). The estimate for unit concentration can be used to predict peak concentrations for a soluble contaminant in a stream by

$$
C p=\frac{(C U)(W)}{Q}
$$

where $C_{p}$ is the peak concentration, in micrograms per liter; $W$ is the weight, in pounds of the spilled contaminant at 100-percent strength; and $C U$ and $Q$ are as previously defined.

\section{DISCUSSION OF RESULTS}

This study shows that discharge is the characteristic most highly related to travel rate. For pool and riffle reaches and for channel-controlled reaches, the next most significant variable is slope, followed by duration frequency. Except for some small samples of reaches, all other variables were below the 95-percent level of significance. For stream reaches with dams, the second most significant variable is the storage caused by the lock or dam, followed by the length of the reach.

The dispersion characteristics, unit concentration and duration of the dye cloud, were tested for channel-controlled streams and for pool- and riffle-type streams. Length of the reach was found to be the most significant variable, followed by discharge. For pool and riffle reaches, slope was the third most significant variable; for channel-controlled streams, duration frequency was found significant.
Duration frequency, although statistically significant in several regression analyses, was not included in the regression equations. The difficulty in estimating flow duration for ungaged streams or for streams with short discharge records makes the presence of that variable impractical for the intended use of the equations; that use being to rapidly estimate travel rates, traveltimes, or dispersion of solutes. The omission of $F$ from the regressions does not seriously affect the reliability of the developed equations. The standard error of fit for travel rate was increased by only 0.01 logarithmic unit, and the standard error of fit for the dispersion equation for channel-controlled reaches was increased by 0.03 logarithmic unit. Deleting $F$ from the regressions allowed slope to be statistically significant in the dispersion equation.

Additional regressions run during the analysis found high correlations between several variables. Very strong relations exist between peak velocity and leading-edge velocity and between unit concentration and duration of the dye cloud. A strong relation for unit concentration was found using time of the peak concentration from injection as an independent variable. These relations are not presented because the characteristics used as independent variables would be unknown in practical use. Strong relationships that may have practical use are, for pool and riffle streams,

$$
C U=1.65 L^{0.41} X^{-0.20} C U U P^{0.91} S^{0.14}
$$

and for channel controlled streams,

$$
C U=4.87 C U U P^{0.84} L^{0.23} X^{-0.23} S^{0.14} .
$$

CUUP in these equations is the unit concentration at an upstream point, and the other terms are as previously defined. The standard errors for these two equations are 20 and 23 : percent, respectively. The equations have value in that an observed peak concentration a short distance below a spill could be used to predict the peak concentration at downstream points more accurately than with the previously given equations.

\section{REFERENCES CITED}

Buchanan, T. J., 1964, Time of travel of soluble contaminants in streams: Am. Soc. Civil Engineers Proc., v. 90, no. SA3, Paper $3932,12 \mathrm{p}$.

Corbett, D. M., and others, 1945, Stream gaging procedure: U.S. Geol. Survey Water-Supply Paper 888,245 p.

Daugherty, R. L., and Ingersoll, A. B., 1954, Fluid mechanics. with engineering applications: New York, McGraw Hill, Inc., $472 \mathrm{p}$.

Godfrey, R. G., and Frederick, B. J., 1963, Dispersion in natural streams: U.S. Geol. Survey open-file rept., 75 p.

Leopold, L. B., and Maddock, Thomas, 1953: The hydraulic geometry of stream channels and some physiographic implications: U.S. Geol. Survey Prof. Paper 252, $57 \mathrm{p}$.

Searcy, J. K., and Davis, L. C., Jr., 1961: Time of travel of water in the Potomac River, Cumberland to Washington: U.S. Geol. Survey Circ. 438, 12 p. 
Simpson, E. S., Bectem, W. A., and Ruggles, F. H., 1959, Hydrologic and tracer studies in the Mohawk River at Knolls Atomic Power Laboratory: U.S. Atomic Energy Comm. Research and Devel. Rept. SO-45, $285 \mathrm{p}$.

Stall, J. B., and Fok, Yu-Si, 1968, Hydraulic geometry of Illinois streams: Urbana, Illinois Univ. Water Resources Center, Research Dept. Rept. 15, 47 p.

Steacy, R. E., 1961, Time of travel of water in the Ohio River, Pittsburgh to Cincinnati: U.S. Geol. Survey Circ. 439, 14 p.

Stewart, M. R., 1967, Time of travel of solutes in Mississippi River from Baton Rouge to New Orleans, Louisiana: U.S. Geol. Survey Hydrol. Inv. Atlas HA-260.
Taylor, K. R., 1970, Travel time and concentration attenuation of a soluble dye in the Monocacy River, Maryland: Maryland Geol. Survey Inf. Circ. 9, 23 p.

Thomas, D. M., and Benson, M. A., 1970: Generalization of stream flow characteristics from drainage basin characteristics: U.S. Gcol. Survey Water-Supply Paper 1975, $55 \mathrm{p}$.

Wilson, J. F., 1969, Fluorometric procedures for dye tracing: U.S. Gcol. Survey Techniques of Water Resources Inv., Book 3, Chap. A-12, $31 \mathrm{p}$.

Yotsukura, N., Fischer, H. B., and Sayre, W. W., 1970, Measurement of mixing characteristics of the Missouri River between Sioux City, Iowa, and Plattsmouth, Nebraska: U.S. Geol. Survey Water-Supply Paper 1899-G, p. G1-G29. 



\title{
INVESTIGATION OF DIFFUSION IN OPEN-CHANNEL FLOWS
}

\author{
By THOMAS N. KEEFER and RAUL S. McQUIVEY, Bay Saint Louis, Miss.
}

\begin{abstract}
This investigation examines the interrelation between turbulent diffusion, dispersion, and the statistical properties of turbulence in an open-channel flow. The results of the study substantiate Philip's concept relating the ratio of Eulerian to estimated Lagrangian time scales and the reciprocal of the longitudinal intensity of turbulence. The relation may be used to predict coefficients of longitudina turbulent diffusion at the water surface and in the flow field. A similar concept using an integral scale based on the longitudinal intensity of turbulence may be used to predict coefficients of both surface and depth-averaged turbulent diffusion in three coordinate directions. Longitudinal space-time velocity correlation measurements can be used to predict the Lagrangian time scale only under limited conditions Within the range of conditions studied, longitudinal diffusion ac counted for 4 to 13 percent of the one-dimensional dispersion process.
\end{abstract}

The streams and rivers of the world have long been used as means for disposing of domestic, agricultural, and industrial wastes. In order to regulate pollution sources so that stream quality standards may be met, means must be found to relate the spread of pollutants to measurable characteristics of the flow field.

The problem is complicated by the fact that two mechanisms are involved in the dispersal process. The first, differential convection, is spreading due to changes in mean velocity of travel within a pollutant cloud. This is a large-scale effect. The second is mixing due to the turbulent velocity fluctuations. This is a smaller scale effect. When concentration of a dispersant is considered in a cross-section average sense and the spreading is considered only in the streamwise direction, differential convection dominates. When viewed in this way, the longitudinal spreading process is referred to as "dispersion." The mixing due to turbulence is referred to as "diffusion." Considerable success has been achieved at predicting the dispersion process, but much work remains to be done with the turbulent diffusion problem.

The difficulties lie in the fact that turbulent diffusion coefficients are described most readily in a Lagrangian rather than Eulerian frame of reference. Unfortunately the most readily conducted experimental measurements are in the Eulerian framework, and no comprehensive theory exists to connect the two frames of reference.

The purpose of this study is to develop workable relations which can be used to predict turbulent diffusion coefficients from turbulence measurements in the Eulerian framework. To meet this objective, the Eulerian-Lagrangian relation proposed by Philip (1967) is verified within experimental accuracy. This relation may be used to predict longitudinal turbulent diffusion coefficients both at the water surface and in the flow field from properties of the longitudinal turbulent intensity. Similar relations are developed which allow the prediction of turbulent diffusion coefficients in the lateral and vertical directions. These predictions are also based on the properties of the longitudinal turbulent intensity.

\section{EXPERIMENTAL EQUIPMENT AND PROCEDURE}

The objectives of the experiments were to (1) measure the statistical properties of concentration profiles from which vertical and lateral diffusion coefficients within the flow field could be determined, (2) measure the longitudinal velocityconcentration covariance to determine the longitudinal turbulent diffusion coefficient within the flow field, (3) measure the distribution of floating particles in order to determine the lateral and longitudinal turbulent diffusion coefficients at the water surface, (4) determine the longitudinal dispersion coefficient using fluorescent dye techniques, and (5) define the turbulence characteristics of the flow field in terms of the longitudinal turbulence intensity and its statistical properties.

\section{Experimental equipment}

All the experiments were conducted in a flume $3.87 \mathrm{ft}$ $(1.18 \mathrm{~m})$ wide, $2 \mathrm{ft}(0.61 \mathrm{~m})$ deep, and $120 \mathrm{ft}(36.6 \mathrm{~m})$ long. To avoid heat and salt solution buildup within the flume, flow was not recirculated. The flume and instrument carriage are illustrated (fig. 1).

Four boundary roughnesses were used in this study. The first was a hydraulically smooth surface provided by the fiberglass finish on the flume. The second was a hydraulically rough surface obtained by covering the flume bed with a layer of $3 / 4$-in. $(1.90 \mathrm{~cm}$ ) diameter crushed rock (fig. $2 \mathrm{~A}$ ). The third was a rough surface obtained by covering the flume bed with a layer of $1 \frac{1}{2}$-in. $(3.81 \mathrm{~cm})$ diameter crushed rock (fig. $\left.2 \mathrm{~B}\right)$. The fourth was a rough surface obtained by scattering at random 3 to 6 -in. $(7.5$ to $15 \mathrm{~cm}$ ) diameter cobbles on top of the $11 / 2$-in. $(3.81 \mathrm{~cm})$ crushed rock (fig. $2 \mathrm{C}$ ). 


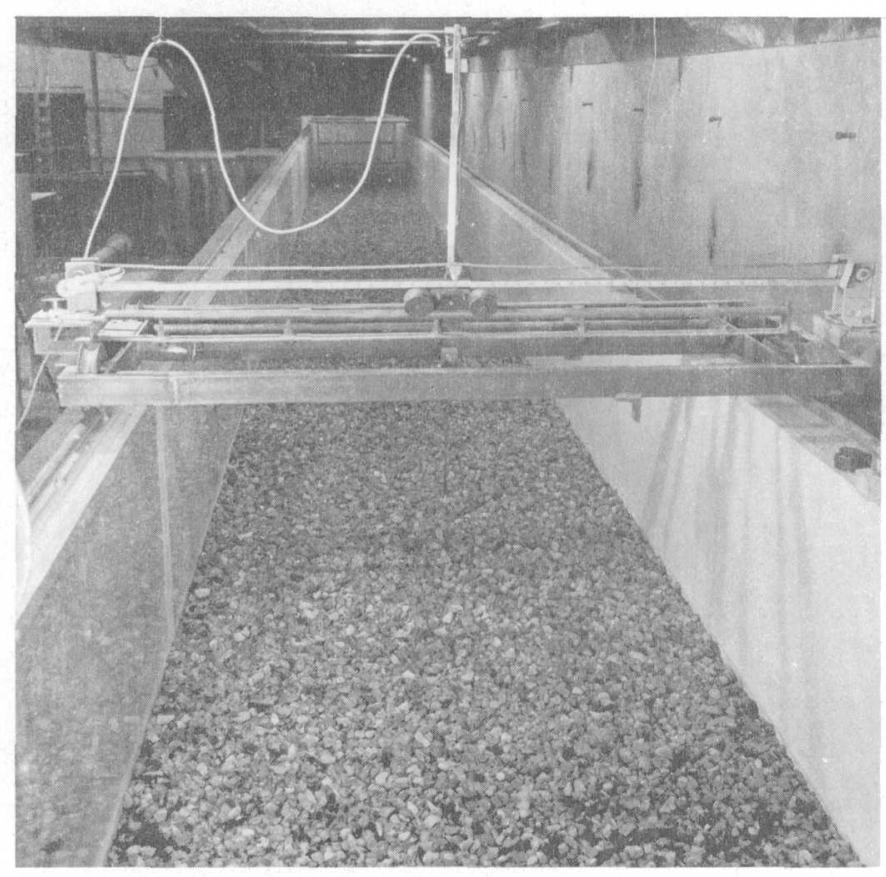

Figure 1.-Flume and instrument carriage.

Salt solution for diffusion experiments was mixed and stored in a pressure tank. Flume water was circulated through a cooling radiator to maintain the solution at the same temperature as the flow. Pressure to force the solution from the tank was supplied by a large air compressor. The salt solution was composed of water, methyl alcohol, and salt. The alcohol content was varied to maintain the mixture at neutral buoyancy. Solution was injected into the flow field through curved nozzles extending through the water surface at the channel centerline.

In order to simulate a uniformly distributed plane source of dispersant for the dispersion experiments, a tilting trough was mounted $5 \mathrm{ft}(1.52 \mathrm{~m})$ above the bed of the flume. When rotated quickly, the trough produced a nearly vertical sheet of dispersant. Rhodamine WT dye was used in these experiments. Dye was detected by a commercially available fluorometer. This allowed measurement of concentration versus time profiles. The output of the florometer was recorded on a stripchart recorder.

Particle diffusion measurements were made by individually dropping small polyethylene particles $(3 / 32$-in., or $0.238 \mathrm{~cm}$, diameter; specific gravity, 0.986) onto the water surface through a funnel located at the centerline of the flume. The particles were collected downstream in a compartmented trap. The particles were timed over the distance to the trap by using a stopwatch.

All salt concentration measurements were made with a single-electrode 'conductivity probe. In addition to the concentration measurements, the probe was used in combina-
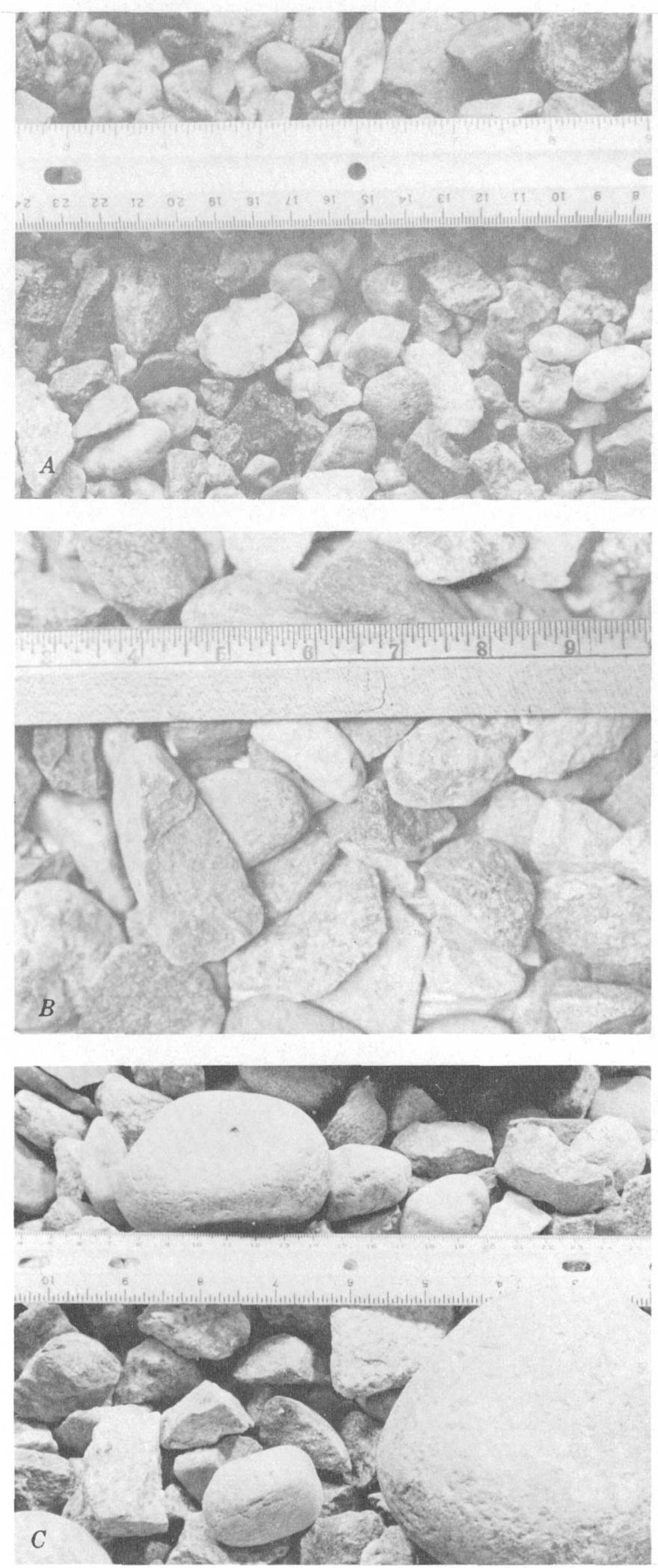

Figure 2.-Boundary roughnesses. $A, 3 / 4$-in. $(1.90-\mathrm{cm})$ rock. $B, 1 \frac{1}{2}$-in. (3.81-cm) rock. C, 6-in. (15-cm) cobble. 
tion with the hot-film anemometer to measure the velocityconcentration covariance. The theory and operation of conductivity probes are documented in Keeler (1964) and Gibson and Schwarz (1963). Details on the construction, operation, and calibration of the probe used in this study are available in Keefer (1.971) and MeQuivey and Keefer (1.972).

Turbulence measurements were made with a dual-channel constant temperature anemometer. Parabolic shaped hot-film sensors were used because of their resistance to signal drifi caused by fluid-borne contaminants.

\section{Experimental procedure}

The turbulence data collection sequence usually began with a series of velocity profiles. Next the longitudinal turbulence intensity measurements were made. Then the longitudinal space-time velocity data were taken. For these measurements two hot-film probes were operated simultancously. One probe was placed at a fixed position on the centerline of the flume, and the other was moved downstream on the centerline from point to point.

The dispersion data sequence consisted of taking 12 concentration versus time profiles at stations downstream of an instantaneous plane-source injection of dispersant. A syphon nozzle was placed at middepth on the centerline at the desired station to record the profiles. Profiles were recorded at six stations below the injection point. Each station was repeated twice.

The salt solution diffusion sequence began with mixing a tank of dispersant. Full scale deflection of the conductivity probe in the injector solution was then checked. During experiments this full deflection was an easily made check on whether the conductivity probe was operating properly.

After the probe was checked for full scale response, it was mounted on the traversing mechanism. The nozzle discharge was adjusted to the desired value and data taking commenced. First, a vertical concentration profile at the centerline was taken at a desired distance downstream of the nozzle. Vertical profiles were followed by horizontal profiles located at the depth of peak concentration in the vertical. This process was repeated for four jet strengths (discharges) for each of the three nozzles. The velocity-concentration covariance measurements were made by operating the single-electrode conductivity probe and hot-film sensor simultaneously and recording both signals on F.M. magnetic tape. Covariance measurements were made over the smooth, $1 \frac{1}{2}-\mathrm{in}$. $(3.81 \mathrm{~cm})$ rock, and 6 -in. $(15 \mathrm{~cm})$ cobble boundaries. A complete description of the measurement technique is available in McQuivey and Keefer (1.972).

The final data sequence was the surface diffusion of particles. Two hundred individual particles were dropped and timed over five distances. After completing a particle experiment at the flow depth used in the salt solution experiments (approxi- mately $1 \mathrm{ft}$ or $0.305 \mathrm{~m}$ ), the depth was cut in half, uniform flow reestablished, and a second set of data collected. A set of dispersion measurements were also made for the one-half depth flows. The particle sequence was completed only over the smooth, $1 \frac{1}{2}-$ inch $(3.81 \mathrm{~cm})$ rock, and 6 -in. $(15 \mathrm{~cm})$ cobble boundaries.

\section{PRESENTATION OF DATA}

The basic hydraulic parameters for the four boundary conditions are shown (table 1). Columns 9 through 14 are completed only for runs S1, TR1, and RBI. where large quantities of data were taken. These were the only runs where concentration profiles were collected for determining diffusion coefficients.

The variation in relative turbulence intensity with depth is illustrated (figs. 3,4). The relative intensity increases in roughly equal steps from the smooth boundary to the 6-in. $(15 \mathrm{~cm})$ cobble boundary. These relations were used to determine the turbulent intensity at the water surface and within the flow field in the subsequent analysis.

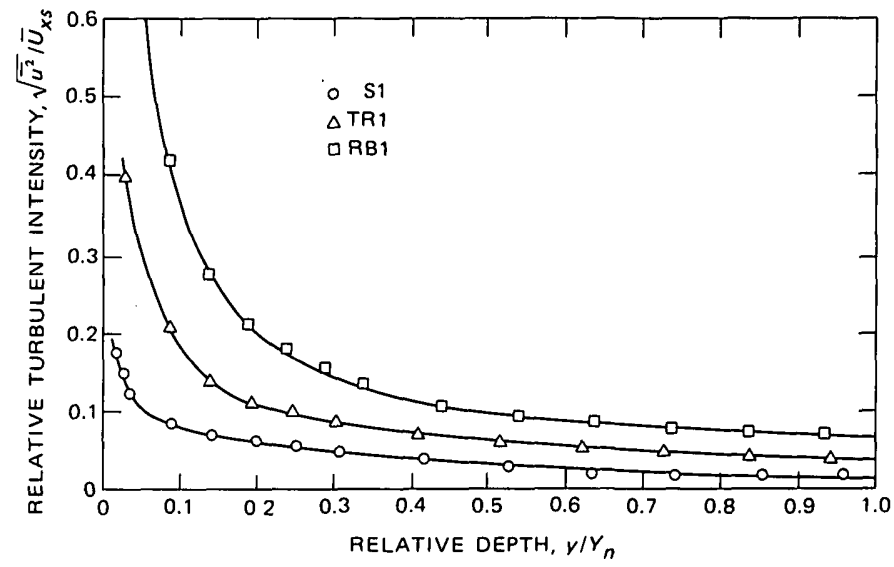

Figure 3.-Relative turbulent intensity versus relative depth at channel centerline for runs S1, TR1, and RB1.

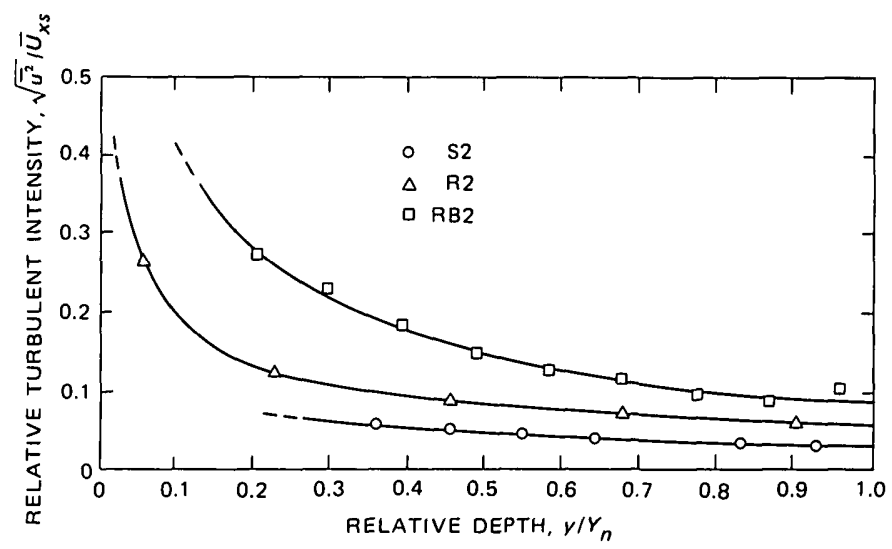

Figure 4.-Relative turbulent intensity versus relative depth at channel centerline for runs $\mathrm{S} 2, \mathrm{R} 2$, and RB2. 
Table 1.-Mean hydraulic parameters

\begin{tabular}{|c|c|c|c|c|c|c|c|c|c|c|c|c|c|}
\hline \multirow{2}{*}{$\begin{array}{l}\text { Boundary } \\
\text { condition }\end{array}$} & \multirow[b]{2}{*}{ 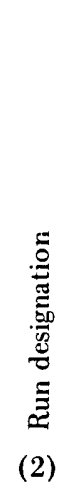 } & \multirow{2}{*}{ 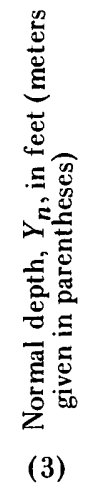 } & \multirow[b]{2}{*}{ 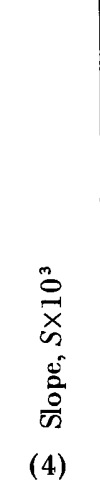 } & \multirow{2}{*}{ 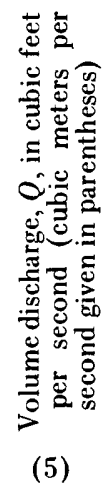 } & \multicolumn{3}{|c|}{$\begin{array}{l}\text { Velocity, in feet per second } \\
\text { (centimeters per second } \\
\text { given in parentheses) }\end{array}$} & \multirow{2}{*}{ 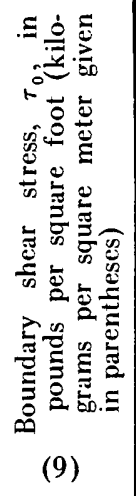 } & \multirow{2}{*}{ 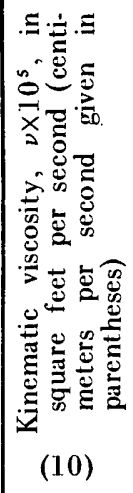 } & \multirow{2}{*}{ 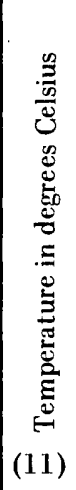 } & \multirow{2}{*}{ 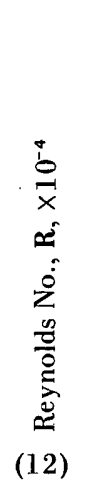 } & \multirow[b]{2}{*}{ 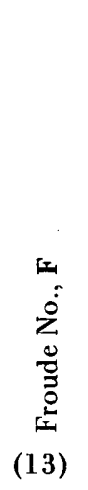 } & \multirow{2}{*}{ 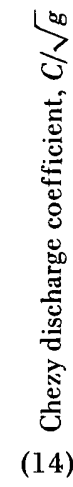 } \\
\hline & & & & & 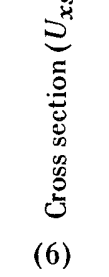 & 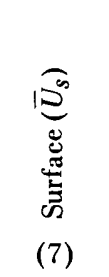 & $\begin{array}{l}\stackrel{D}{*}^{*} \\
\text { 㺼 } \\
(8)\end{array}$ & & & & & & \\
\hline Smooth & $\begin{array}{l}\mathrm{S} 1 \\
\mathrm{~S} 2\end{array}$ & $\begin{array}{c}0.915 \\
(.279) \\
.528 \\
(.161)\end{array}$ & $\begin{array}{r}0.119 \\
.143\end{array}$ & $\begin{array}{l}3.672 \\
(.104) \\
1.643 \\
(.047)\end{array}$ & $\begin{array}{c}1.036 \\
(31.6) \\
.805 \\
(24.6)\end{array}$ & $\begin{array}{c}1.172 \\
(35.7) \\
.934 \\
(28.4)\end{array}$ & $\begin{array}{c}0.0616 \\
(1.88) \\
.0415 \\
(1.26)\end{array}$ & $\begin{array}{l}0.0046 \\
(.0225) \\
\cdots\end{array}$ & $\begin{array}{l}1.62 \\
(1510) \\
\cdots \cdots\end{array}$ & 5.20 & 5.851 & 0.191 & 16.8 \\
\hline $\begin{array}{l}\text { 3/4-in. }(1.91-\mathrm{cm}) \\
\text { rock. } \\
11 / 2-\text { in. }(3.81-\mathrm{cm})\end{array}$ & $\begin{array}{r}\text { TRI } \\
\text { R1 }\end{array}$ & $\begin{array}{l}.933 \\
(.284) \\
892\end{array}$ & .324 & $\begin{array}{l}3.071 \\
(.087) \\
3.450\end{array}$ & $\begin{array}{r}.849 \\
(25.9) \\
1000\end{array}$ & $\ldots$ & $\begin{array}{r}.0803 \\
(2.45) \\
0805\end{array}$ & $\begin{array}{c}.0125 \\
(.0612)\end{array}$ & $\begin{array}{c}1.72 \\
(1600)\end{array}$ & 2.70 & 4.605 & .155 & 10.6 \\
\hline $\begin{array}{l}1.1 / 2-\mathrm{in} .(3.81-\mathrm{cm}) \\
\text { rock. }\end{array}$ & $\mathrm{R} 1$ & $\begin{array}{c}.892 \\
(.272) \\
.469 \\
(.143)\end{array}$ & $\begin{array}{l}.367 \\
.394\end{array}$ & $\begin{array}{l}3.450 \\
(.098) \\
1.302 \\
(.037)\end{array}$ & $\begin{array}{c}1.000 \\
(30.5) \\
.721 \\
(22.0)\end{array}$ & $\begin{array}{c}1.188 \\
(36.2) \\
.815 \\
(24.8)\end{array}$ & $\begin{array}{c}.0805 \\
(2.45) \\
.0694 \\
(2.11)\end{array}$ & & & & & & $\ldots$ \\
\hline $\begin{array}{l}\text { 6-in. }(15-\mathrm{cm}) \\
\text { cobble. }\end{array}$ & $\begin{array}{l}\text { RB1 } \\
\text { RB2 }\end{array}$ & $\begin{array}{c}.945 \\
(.288) \\
.528 \\
(.161)\end{array}$ & .744 & $\begin{array}{l}3.205 \\
(.091) \\
1.591 \\
(.045)\end{array}$ & $\begin{array}{c}.875 \\
(26.7) \\
.780 \\
(23.8)\end{array}$ & $\begin{array}{c}1.190 \\
(36.2) \\
.930 \\
(28.4)\end{array}$ & $\begin{array}{c}.0938 \\
(2.86) \\
.0996 \\
(3.04)\end{array}$ & $\begin{array}{l}.0170 \\
(.0832) \\
\ldots\end{array}$ & $\begin{array}{l}1.73 \\
(1610) \\
\cdots\end{array}$ & 2.65 & 4.779 & .159 & 9.3 \\
\hline
\end{tabular}

Table 2 presents the variation of the Eulerian integral time scale, $T_{E}$, with relative depth, $y / Y_{N}$, for the smooth, $3 / 4$-in. $(1.90 \mathrm{~cm})$ rock, and 6 -in. $(15 \mathrm{~cm})$ cobble boundaries at the channel centerline. The values of $T_{E}$ were found by a numerical approximation of the formula,

$$
T_{E}=\int_{0}^{\tau}{ }_{\max } R_{E}(\tau) \mathrm{d} \tau
$$

where $R_{E}(\tau)$ is the autocorrelation function and $\tau_{\max }$ is the time where $R_{E}$ first crosses zero. $T_{E}$ does not show any systematic variation with depth. The average values are 1.519 ,
0.873 , and 0.813 s for runs S1, TR1, and RB1, respectively. These averages were obtained from 18 to 20 values and not just the 9 values shown in the table.

The results of the longitudinal space-time velocity correlation measurements over the smooth boundary (S1) and over the $3 / 4$-in. (1.91.-cm) rock boundary (TR1) are shown (fig. 5). The time scale value shown below each curve was obtained by integrating the estimated envelope curve. No general expression could be found to describe the envelope curve. Such analysis will require more accurate and detailed measurements than are currently possible.

Table 2.-Eulerian integral time scales

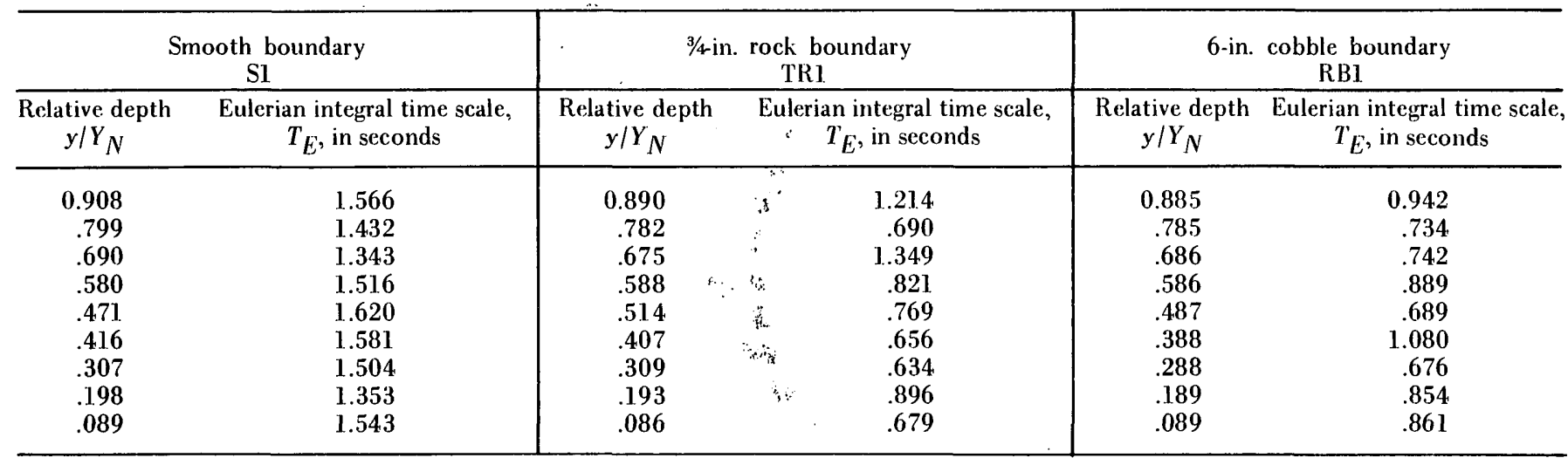




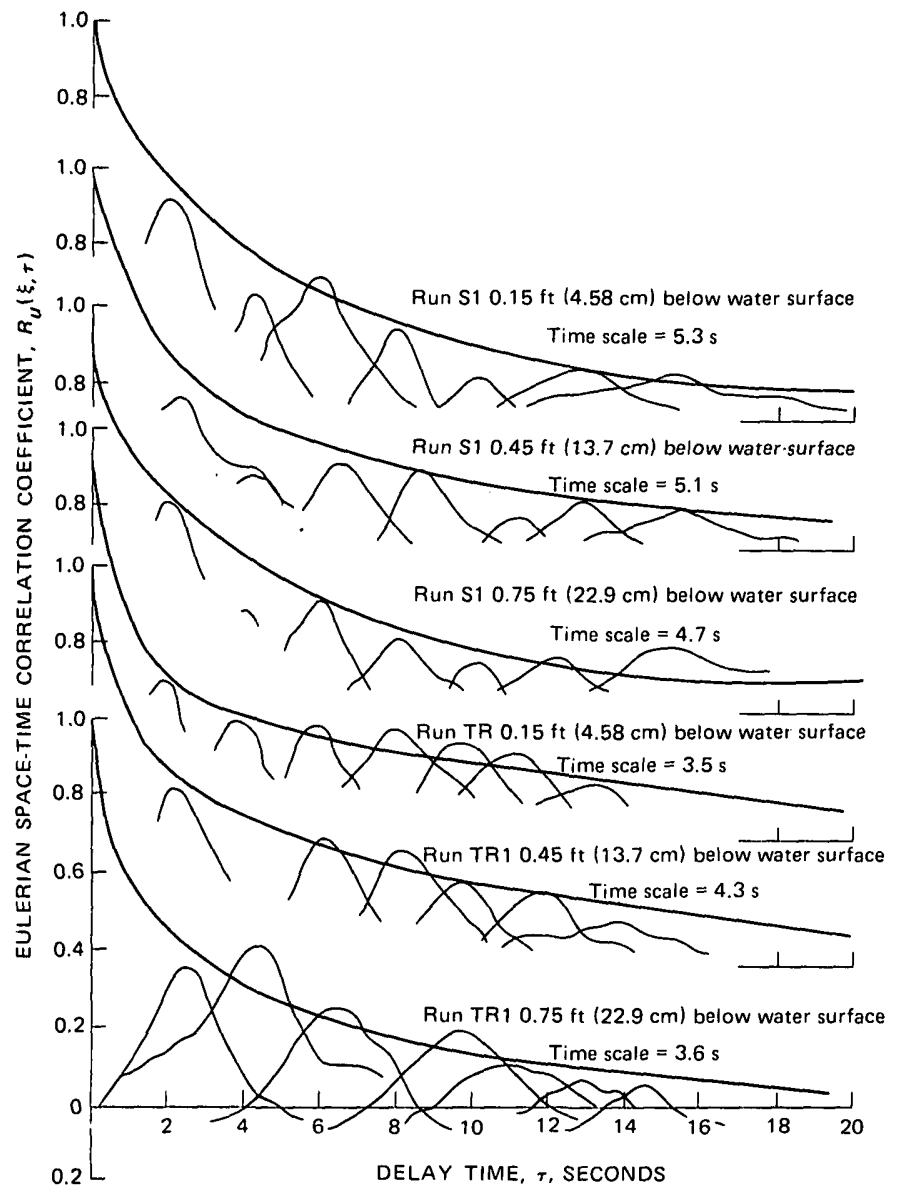

Figure 5.-Longitudinal space-time velocity correlations.

With minor exceptions, the diffusion and dispersion data were all analyzed by the same procedure. For the dispersion and lateral and vertical diffusion within the flow field, the first step in the reduction was to convert the analog concentration (voltage) versus time or distance curves to digital punch card form. A computer program was then written which analyzed each profile for mean, standard deviation, and variance, $\overline{\sigma_{i}^{2}}$. The program fit least squares lines through the sets of variances and solved for the vertical and lateral turbulent diffusion coefficients $\epsilon_{y}$ and $\epsilon_{z}$ from the equation,

$$
\epsilon_{i}=\frac{1}{2} \frac{\mathrm{d} \sigma_{i}^{2}}{\mathrm{~d} t}
$$

as suggested by Sayre and Chang (1968). Surface diffusion coefficients in the $x$ and $z$ directions were determined from the floating particle data. An electronic desk calculator was used to compute the variance of the traveltimes and the variance of the lateral concentration distributions as indicated by the compartmented trap. The surface diffusion coefficients in the longitudinal and lateral directions, $\epsilon_{x s}$, and $\epsilon_{z s}$, were then computed from formulas based on equation 2 . The reduction procedure for the velocity-concentration covariance data is described in detail in McQuivey and Keefer (1.972).

The results of the diffusion and dispersion studies are shown (table 3). The values reported for $\epsilon_{x}$ and $\epsilon_{z}$ for each boundary condition are the averages of 12 values obtained with 3 different size nozzles at 4 injection rates each. The values for $\epsilon_{x}$ are the average values from the velocity-concentration covariance measurements.

\section{DISCUSSION OF RESULTS}

As stated in the introduction, the primary purpose of this report is to develop relations which can be used to predict turbulent diffusion coefficients in the three coordinate directions from the properties of turbulence measurements in the Eulerian framework. The discussion is divided into two general areas. First, the lateral, longitudinal, and vertical diffusion coefficients will be analyzed using an extension of Philip's (1967) hypothesis. Included is a discussion of the

'Table 3.-Diffusion and dispersion eoefficients

[Data given in square feet per second and in parentheses in square centimeters per second. N.d., not determined]

\begin{tabular}{|c|c|c|c|c|c|c|c|}
\hline Run designation & S1 & $\mathrm{S} 2$ & TR1. & $\mathrm{R} 1$ & $\mathrm{R} 2$ & $\mathrm{RB}$ ! & $\mathrm{RB} 2$ \\
\hline $\begin{array}{l}\text { Longitudinal dispersion coefficient } D_{x} \\
\text { (Rhodamine dye dispersant) } \ldots \ldots \ldots\end{array}$ & $\begin{array}{l}0.226 \\
(210)\end{array}$ & $\begin{array}{l}0.186 \\
(1.73)\end{array}$ & $\begin{array}{l}0.521 \\
(485)\end{array}$ & $\begin{array}{l}0.274 \\
(255)\end{array}$ & $\begin{array}{l}0.169 \\
(157)\end{array}$ & $\begin{array}{l}0.877 \\
(816)\end{array}$ & $\begin{array}{l}0.797 \\
(741)\end{array}$ \\
\hline $\begin{array}{l}\text { Longitudinal turbulent diffusion coeffi- } \\
\text { cient, } \epsilon_{x} \text { (salt solution dispersant). . . }\end{array}$ & $\begin{array}{c}.0118 \\
(1.1 .0)\end{array}$ & N.d. & N.d. & $\begin{array}{l}.0366 \\
(34.0)\end{array}$ & N.d. & $\begin{array}{c}.0327 \\
(30.4)\end{array}$ & N.d. \\
\hline $\begin{array}{l}\text { Longitudinal turbulent diffusion coeffi- } \\
\text { cient at water surface, } \epsilon_{x s} \text { (poly- } \\
\text { ethylene particle dispersant). } \ldots \ldots \ldots\end{array}$ & $\begin{array}{l}.00916 \\
(8.51)\end{array}$ & $\begin{array}{l}.01060 \\
(9.85)\end{array}$ & N.d. & $\begin{array}{l}.03354 \\
(31.2)\end{array}$ & $\begin{array}{l}.01687 \\
(15.7)\end{array}$ & $\begin{array}{l}.03089 \\
(28.7)\end{array}$ & $\begin{array}{l}.02812 \\
(26.1)\end{array}$ \\
\hline $\begin{array}{l}\text { Vertical turbulent diffusion coefficient, } \\
\epsilon_{y} \text { (salt solution dispersant). } \ldots \ldots \ldots\end{array}$ & $\begin{array}{l}.00257 \\
(2.39)\end{array}$ & N.d. & $\begin{array}{l}.00223 \\
(2.07)\end{array}$ & N.d. & N.d. & $\begin{array}{l}.00387 \\
(3.60)\end{array}$ & N.d. \\
\hline $\begin{array}{l}\text { Lateral turbulent diffusion coefficient, } \\
\epsilon_{z} \text { (salt solution dispersant). . . . . . } \\
\text { Lateral turbulent diffusion coefficient at }\end{array}$ & $\begin{array}{l}.00411 \\
(3.82)\end{array}$ & $\begin{array}{l}.00360 \\
(3.35)\end{array}$ & $\begin{array}{l}.00731 \\
(6.80)\end{array}$ & N.d. & N.d. & $\begin{array}{l}.01193 \\
(11.1)\end{array}$ & N.d. \\
\hline $\begin{array}{l}\text { water surface, } \epsilon_{x s} \text { (polyethylene parti- } \\
\text { cle dispersant). } \ldots \ldots \ldots \ldots \ldots \ldots \ldots\end{array}$ & $\begin{array}{l}.00388 \\
(3.61)\end{array}$ & $\begin{array}{l}.00360 \\
(3.35)\end{array}$ & N.d. & $\begin{array}{l}.01074 \\
(10.0)\end{array}$ & $\begin{array}{l}.00668 \\
(6.22)\end{array}$ & $\begin{array}{l}.01110 \\
(1.0 .3)\end{array}$ & $\begin{array}{l}.01240 \\
(11.5)\end{array}$ \\
\hline
\end{tabular}


applicability of space-time correlations for predicting the diffusion process. Finally, some general comments are made on the relation between longitudinal dispersion and turbulent "diffusion".

A brief review of the theory of turbulent diffusion is in order so that the reader may more clearly understand the problem of relating the turbulent diffusion coefficients to the statistical properties of Eulerian turbulence measurements. The fundamental connection between the turbulent diffusion coefficients and the turbulent velocity fluctuations is established by Batchelor (1949),

$$
\epsilon_{i j}=\frac{1}{2} \frac{\mathrm{d} \sigma_{i j}^{2}}{\mathrm{~d} t},
$$

and Taylor's (1954) theorem,

$\overline{\sigma_{i j}^{2}}=2 \overline{\left(u_{i}^{2} u_{j}^{2}\right)} \frac{1}{2} \int_{0}^{t} \int_{0}^{t^{*}} R_{L_{i j}}(\tau)+R_{L_{j i}}(\tau) \mathrm{d} \tau \mathrm{d} t^{*}$

where $u_{i}$ and $u_{j}$ are turbulent velocity fluctuations and $R_{L_{i j}}$ $(\tau)$ is the Lagrangian correlation function. Both of these equations are Lagrangian in nature. That is, the $u_{i}$ and $R_{L_{i j}}(\tau)$ are velocities and correlations of a single particle traveling with the flow field and not velocities and correlations at a single point. These relations are deceivingly simple. No current experimental techniques allow ready evaluation of the Lagrangian velocity components. The Lagrangian correlation function is thus also not readily measurable. Eulerian velocities and correlations, at least in the longitudinal direction, are measured with relative ease. Assumptions are thus necessary about the relation between Lagrangian properties (measured by following single particles) and Eulerian properties (measured by watching many particles move past a point).

The first such assumption is that the time-average velocity fluctuations, the $\bar{u}_{i}$ components, are the same in either frame of reference. In a uniform velocity field this would seem justified. Little experimental evidence exists to either support or contradict this assumption.

The next assumption is the form of the relation between the Eulerian and Lagrangian correlation functions. In order to attack this question Philip considered the problem in a field of homogeneous, isotropic turbulence with zero mean motion. This allowed consideration of the longitudinal velocity fluctuations only. After developing an Eulerian-Lagrangrian relation under these restrictive conditions, Philip transformed into a space with mean motion. This led to a time scale relation of the form,

$$
\frac{T_{L}}{T_{E}}=\left(1+\frac{\omega^{2}}{\overline{u^{2}}}\right)^{1 / 2} F(\omega)
$$

where $\omega$ and $F(\omega)$ are functions of the absolute turbulence intensity, $\sqrt{\overline{u^{2}}}$, and the time scale ratio $T_{L} / T_{E}$. The nature of
Philip's relation suggests a dependence of $T_{L} / T_{E}$ on the inverse of the turbulence intensity.

The relation proposed by Philip for $\omega^{2}=1.0$ is shown (fig. 6). Also shown in the figure are data from this study and from

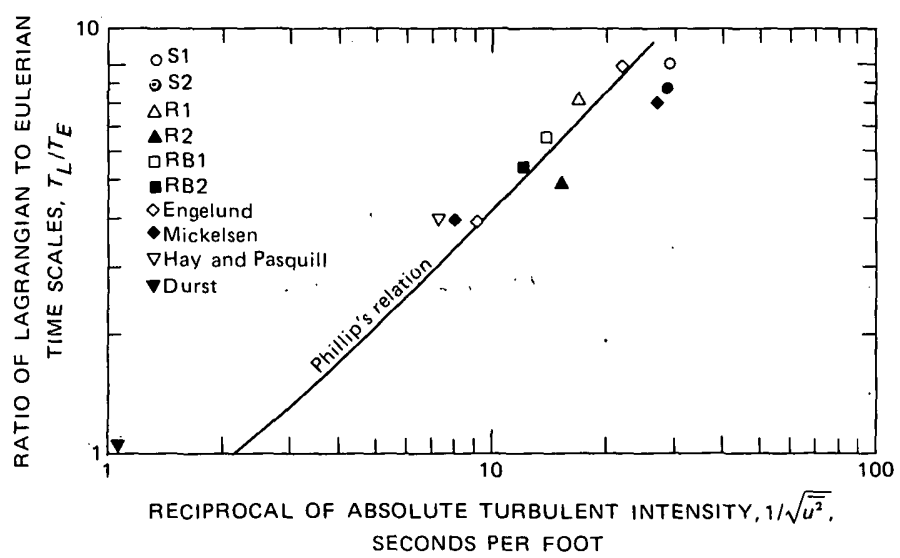

Figure 6.-Philip's hypothesis for longitudinal surface diffusion. Data of F. Engelund, W. R. Mickelsen, J. S. Hay and F. Pasquill, and Durst as reported by Philip (1967). Seconds per foot times 0.0328 equals seconds per centimeter.

the work of F. Engelund, W. R. Mickelsen, J. S. Hay and F. Pasquill, and Durst as reported by Philip. The Lagrangian time scale values were generated from equations 3 and 4 combined and written for the longitudinal direction at the water surface as

$$
T_{L}=\frac{\epsilon_{x s}}{\overline{u^{2}}} .
$$

The surface turbulent diffusion coefficients, $\epsilon_{x s}$, from the particle experiments were divided by the surface turbulent intensity extrapolated from figure 3 . The Eulerian time scale values were obtained from the autocorrelation functions of the longitudinal turbulence intensity records at the channel centerline. While agreement with the curve is not perfect $( \pm 30$ percent scatter), it is certainly within the experimental accuracy.

Extension of Philip's concept to Eulerian-Lagrangian relations within the flow field is a much more complex problem both experimentally and theoretically. First, turbulence in a rectangular open channel, except near boundaries, is homogeneous but anisotropic in the $x-z$ plane and both nonhomogeneous and anisotropic in the $x-y$ plane. Second, no direct means of obtaining either the Eulerian velocity or time scale in the $y$ and $z$ directions is currently perfected. Split-film anemometers may soon make such measurements possible, but several years will elapse before readily useable systems are available. The root-mean-square values of the velocity fluctuations, $\sqrt{\overline{v^{2}}}$ and $\sqrt{\overline{w^{2}}}$ could be approximated as fixed percentages of $\sqrt{\overline{u^{2}}}$ on existing experimental grounds, but no theory exists for a lateral or vertical Eulerian time scale. Thus even if a theoretical relation between the vertical or lateral 
velocity fluctuations, $\overline{v^{2}}$ and $\overline{w^{2}}$, and the ratio of the time scales $T_{L y} / T_{E y}$ and $T_{L z} / T_{E z}$ could be found, it would be technically infeasible to check. Justification is needed for relating vertical and lateral time scales and diffusion processes to the readily measurable longitudinal Eulerian properties of the flow.

In order to make such a justification we must look at the effect of anisotropy and inhomogeneity on the flow field. Anisotropy of a homogeneous turbulence field means that the time-average velocity fluctuations are no longer equal but maintain some constant ratio. This means that $\sqrt{v^{2}}=$ $K_{1} \sqrt{\overline{u^{2}}}$ and $\sqrt{\overline{w^{2}}}=K_{2} \sqrt{\overline{u^{2}}}$. This being true, it is not unreasonable to expect some constant relation between the correlation functions and time scales in the three directions. If such a constant relation exists, then whatever connection exists between $T_{L y} / T_{E y}$ and $\sqrt{\overline{v^{2}}}$ or $T_{L z} / T_{E z}$ and $\sqrt{\overline{w^{2}}}$ must differ at most by some constant from the relation between $T_{L y} / T_{E y}$ or $T_{L z} / T_{E z}$ and $\sqrt{\overline{u^{2}}}$. Since, with the exception of the region near the sidewalls, open-channel flow is approximately homogeneous and anisotropic in the $x-z$ plane, we might expect a dependence of $T_{L z} / T_{E z}$ on $\sqrt{u^{2}}$ similar in form to that proposed by Philip for the $x$-direction. Such a relation is not measurable, however, since neither $T_{L z}$ or $T_{E z}$ are measurable. $T_{L z}$ could be approximated by dividing $\epsilon_{z}$ by $K_{2} u^{2}$, analogous to equation 6 , but the value for $K_{2}$ is not known for an open channel. However, by defining a new time scale $T_{A z}$ as

$$
T_{A z}=\frac{\epsilon_{z}}{\overline{u^{2}}}
$$

we bypass the problem. This new time scale should differ at most by some constant from the lateral Lagrangian time scale, $T_{L, z}$. It would not seem unreasonable that the ratio of this new time scale to the longitudinal Eulerian time scale, $T_{A z} / T_{E}$, might show a dependence on $\sqrt{\overline{u^{2}}}$.

The effect of inhomogeneity is difficult to assess theoretically. When inhomogeneities are present no fixed relation exists between the velocity fluctuations in the three coordinate directions. Thus there is no a priori reason to expect a dependence on the Eulerian-Lagrangian time scale ratio in the vertical direction, $T_{L y} / T_{E y}$, on $\sqrt{\bar{u}^{2}}$. To bypass this problem we must resort to heuristic arguments. Once again there is no way of directly measuring a value for the Lagrangian time scale or the Eulerian time scale in the $y$-direction. It seems plausible, then, to resort to a time scale based on the longitudinal intensity and the $y$-direction diffusion coefficient. This time scale is defined as follows

$$
T_{A y}=\frac{\epsilon_{y}}{\overline{u^{2}}},
$$

where $\epsilon_{y}$ is the depth-averaged turbulent diffusion coefficient and reflects the effect of a depth-averaged value of the turbulent velocity fluctuations. By depth averaging, the effect of inhomogeneity in the $y$-direction is removed since the velocity and turbulence structure do not vary from station to station in steady, uniform open-channel flow. We might now expect a variation of this depth-averaged time scale with $\sqrt{\overline{u^{2}}}$. Experimental evidence from this study will now be presented to show that relations such as equations 7 and 8 do produce workable results.

The first application of the analysis based on the new time scales is to lateral diffusion at the water surface. The ratio of the lateral integral time scale to the longitudinal Eulerian integral time scale $T_{A z} / T_{E}$ versus the inverse of the longitudinal turbulent intensity, $1 / \sqrt{\overline{u^{2}}}$ is shown (fig. 7). Also shown is a line based on Philip's relation. The data fit the line with a \pm 20 percent scatter.

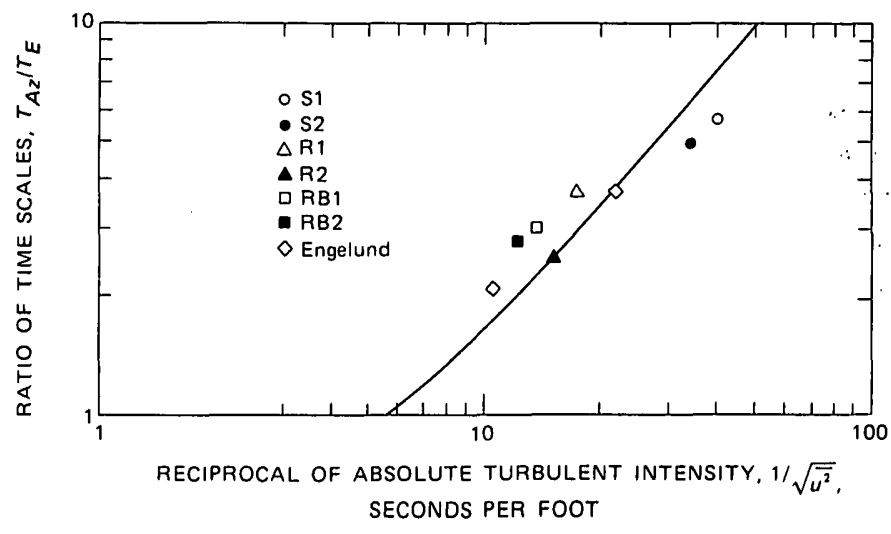

Figure 7.-Variation of lateral integral time scale ratio at water surface with inverse of absolute longitudinal turbulent intensity. F. Engelund's data as reported by Philip (1967). Seconds per foot times 0.0328 equals seconds per centimeter.

A similar analysis was next made on the depth-averaged diffusion coefficients obtained from the salt-solution jet studies. These coefficients are the mean value of the 12 obtained for each boundary condition. The relation between $T_{A i} / T_{E}$ and $1 / \sqrt{u^{2}}$ is shown (fig. 8). The time scale ratios were obtained from equation 6 with the centerline value of $\sqrt{u^{2}}$ averaged at 9 dimensionless depths, 0.1 to 0.9 . Also shown are lines with the average slope of Philip's relation. The closeness of the horizontal and vertical data to straight lines is quite good.

For the longitudinal direction the $T_{L x} / T_{E}$ versus $1 / \sqrt{u^{2}}$ relation is less satisfactory. Because the points were obtained from the average $\epsilon_{x}$ values in the velocity-concentration covariance measurements, this is not surprising. The experimental errors and assumptions in the measurements are not small, as discussed in McQuivey and Keefer (1.972).

The importance of this analysis is that diffusion coefficients can be obtained from readily made Eulerian turbulence characteristics by reversing the process used to generate figures 6,7 , and 8 . First, the longitudinal turbulence intensity is measured at the desired location in the flow, or at sufficient points to obtain a depth-averaged value of $\sqrt{u^{2}}$. Next the 


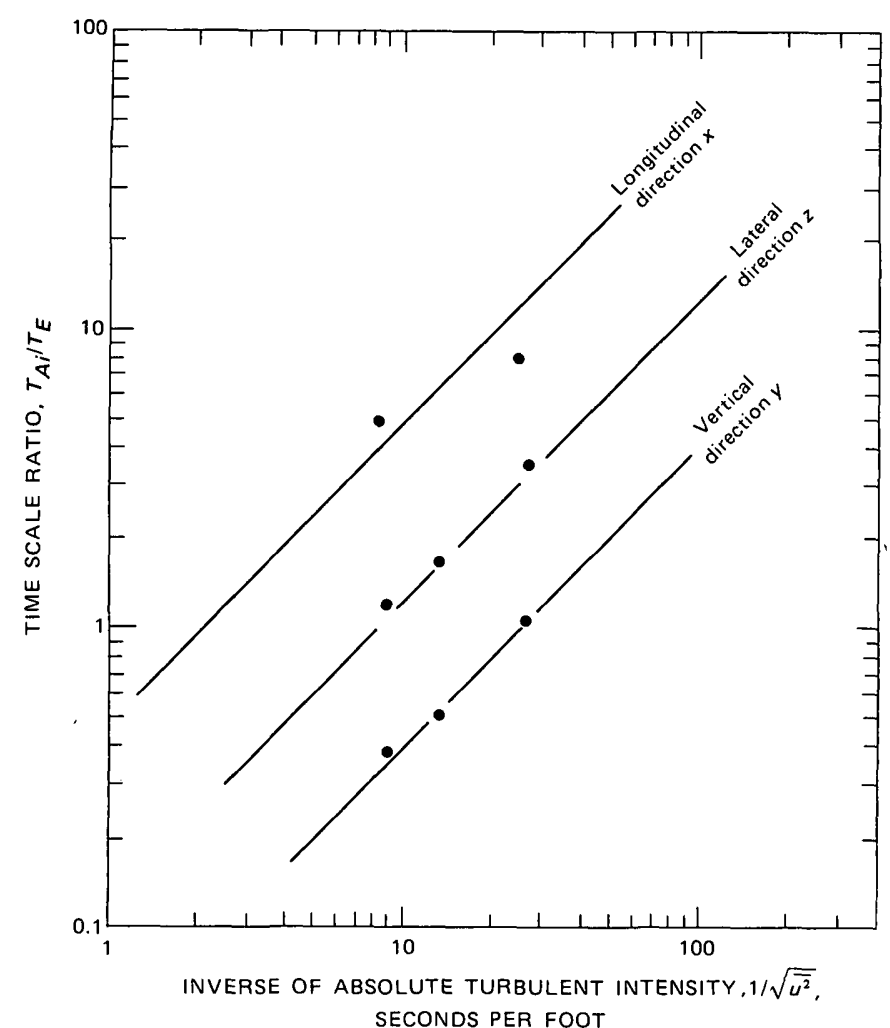

Figure 8.- Variation of integral time scale ratio with inverse of depthaveraged longitudinal turbulent intensity. Longitudinal data $(X)$ obtained from velocity concentration covariance. Seconds per foot times 0.0328 equals seconds per centimeter.

Eulerian time scale, $T_{E}$, is determined from the autocorrelation of the turbulence signal (depth average for depth-averaged coefficients). Next the proper figure, 6 through 8 , is entered to determine $T_{L i}$ or $T_{A i}$ over $T_{E}$. Since $T_{E}$ is known, $T_{L i}$ or $T_{A i}$ can be computed, allowing $\epsilon_{i}$ to be determined as

$$
\epsilon_{i}=\overline{u^{2}} T_{T i} \text { or } \epsilon_{i}=\overline{u^{2}} T_{A i}
$$

The purpose of the space-time velocity correlations was to determine to what degree of approximation they could be used as a substitute for Lagrangian correlation measurements as suggested by Baldwin and Mickelsen (1948). This comparison is made by checking the Lagrangian time scales, $T_{L x}$, obtained through the diffusion measurements and equation 6 against the time scale values obtained from integrating the envelope curves in figure 5. The results are shown (table 4). For the smooth boundary (S1) the Lagrangian time scale of $13.52 \mathrm{~s}$ exceeds the average space-time integral scale of $5.03 \mathrm{~s}$ by a factor of 2.7 . For the $3 / 4$ in. rock boundary (TR1) the Lagrangian time scale of $7.68 \mathrm{~s}$ exceeds the average space-time integral scale of $3.80 \mathrm{~s}$ by a factor of 2.02 . Had these values been used to predict the longitudinal diffusion coefficient from equation 9 , the results would have been low by the same factors. This is in direct contrast to the results of Baldwin and
Table 4.-Space-time and Lagrangian time scales

\begin{tabular}{lcccc}
\hline & \multicolumn{3}{c}{$\begin{array}{c}\text { Longitudinal space-time integral } \\
\text { time scale (seconds) }\end{array}$} & $\begin{array}{c}\text { Lagrangian } \\
\text { Boundary }\end{array}$ \\
\cline { 2 - 4 } condition & $\begin{array}{c}0.15 \mathrm{ft} \\
(4.58 \mathrm{~cm}) \\
\text { below water } \\
\text { surface }\end{array}$ & $\begin{array}{c}0.45 \mathrm{ft} \\
(13.7 \mathrm{~cm}) \\
\text { below water } \\
\text { surface }\end{array}$ & $\begin{array}{c}0.75 \mathrm{ft} \\
(22.9 \mathrm{~cm}) \\
\text { below water } \\
\text { surface }\end{array}$ & $\begin{array}{c}T_{L} \\
\text { (seconds) }\end{array}$ \\
\hline S1..... & 5.30 & 5.10 & 4.70 & 13.52 \\
TR1 $\ldots$ & 3.50 & 4.30 & 3.60 & 7.68 \\
\hline
\end{tabular}

Mickelsen whose results were overpredicted by roughly the same amount.

Baldwin and Mickelsen's results can be explained by considering the Eulerian-Lagrangian relation of Philip. This relation shows that the Eulerian-Lagrangian time scale ratio is a function of the absolute turbulent intensity. From the properties of the space-time correlation it can be seen that the space-time integral scale is always greater than or equal to the Eulerian integral scale, $T_{E}$. This is because the $R_{u}(0, \tau)$ space-time correlation curve is the autocorrelation curve and hence contains the same area as $R(\tau)$, that is $T_{E}$. Also for any small finite probe spacing, $R_{u}(\xi, \tau)$ will have some finite area unless the turbulence were to decay in zero time. Thus an envelope curve of $R_{u}(\xi, \tau)$ must have a greater area contained within it than the autocorrelation and hence a bigger time scale. By considering figure 6 it can be seen that for flows where the reciprocal of the turbulent intensity $1 / \sqrt{\overline{u^{2}}}$ is less than 2.1 that $T_{L x} / T_{E x}$ is less than one. Thus $T_{L x}$ is less than $T_{E}$ and must therefore be less than the space-time integral scale also. It is difficult to visualize how such a relation between the time scales might occur. The result, however, is consistent with experimental results.

The data from this study afford a unique opportunity to study the effect of longitudinal diffusion on dispersion. It has been accepted for some time that the dominant mechanism in dispersion is the variation of the mean velocity within a cross section, both vertical and lateral. The role of the longitudinal turbulent velocity fluctuations is assumed to be small. The turbulent transfer coefficient, $\epsilon_{x}$, is approximated by the depth-average value of the vertical transfer coefficient, $\epsilon_{y}$. Using this approximation, $\epsilon_{x}$ is approximately 1 percent of $D_{x}$, the dispersion coefficient, Sayre and Chang (1968). Using values from table 3 it may be seen that this is a poor approximation. For runs $S 1$ and $S 2, \epsilon_{x s}$ was 4.1 percent and 5.7 percent of $D_{x}$, respectively. For runs RB1 and RB2, $\epsilon_{x s}$ was 3.52 percent and 3.53 percent of $D_{x}$, respectively. These comparisons are based on the surface values of $\epsilon_{x s}$, but the depth-average values, $\epsilon_{x}$, obtained from the covariance study are even higher percentages of $D_{x}$, being 5.2 percent, 13.1 percent, and 3.7 percent for runs $A 1, R 1$, and $R B 1$, respectively. Thus, while neglecting or minimizing the effect of $\epsilon_{x}$ on dispersion may not cause large errors, the effect is greater than previously thought. 


\section{SUMMARY AND CONCLUSIONS}

The results of this study verify with a scatter of \pm 30 percent Philip's hypothesis connecting the ratio of Eulerian to Lagrangian time scales in the longitudinal direction and the reciprocal of the longitudinal turbulent intensity. It may be used to predict longitudinal turbulent diffusion coefficients at the water surface.

A similar concept is developed using an integral time scale based on the longitudinal turbulent intensity which may be used to predict both surface and depth-averaged turbulent diffusion coefficients in the vertical, lateral, and longitudinal directions for floating particles and salt-solution jets within \pm 25 percent accuracy. Data indicate no scale effect in the relations which should thus be good for both model and prototype predictions of turbulent transfer coefficients.

Space-time velocity correlations in the longitudinal direction were made over the smooth and $3 / 4-i n .(1.91 \mathrm{~cm})$ rock roughnesses. Time, scale values obtained were 200 to 250 percent low compared to estimated Lagrangian time scales. This is contrasted to the results of Baldwin and Mickelsen whose results were approximately the same amount high. The Eulerian-Lagrangian relation of Philip suggests a dependence of the Lagrangian and space-time scales on the longitudinal turbulence intensity which would result in such a discrepancy.

Comparison of the longitudinal turbulent diffusion coefficient to the one-dimensional dispersion coefficient indicates that turbulent diffusion may account for as much as 13. percent of the dispersion process.

\section{REFERENCES CITED}

Baldwin, L. V., and Mickelsen, W. R., 1948, Turbulent diffusion and anemometer measurements: Am. Soc. Civil Engineers Trans., v. 74, p. $639-697$.

Batchelor, G. K., 1949, Diffusion in a field of homogeneous turbuIence: Australian Jour. Sci. Research, v. 2, p. 437-450.

Keefer, T. N., 1.971, The relation of turbulence to diffusion in openchannel flows: Fort Collins, Colorado State Univ., Ph. D. dissert., 11.4. p.

Keeler, R. N., 1964, Mixing and chemical reaction in turbulent flow reactors: Livermore, Calif., Earnest O. Lawrence Radiation Laboratory, Rept. UCRL-7852, 1.80 p.

McQuivey, R. S., and Keefer, T. N., 1972, Measurement of the velocity-concentration covariance: Am. Soc. Civil Engineers, Jour. Hydraulics Div., v. 98, no. HY9, Proc. Paper 9184, p. 1629-1646.

Philip, J. R., 1.967, Relation between Eulerian ánd Lagrangian statistics: Physics Fluids Supp., p. S69-S71.

Sayre, W. W., and Chang, F. M., 1968, A laboratory investigation of open-channel dispersion processes for dissolved, suspended, and floating dispersants: U.S. Geol. Survey Prof. Paper 433-E, 71 p.

Taylor, G. I., 1.954, The dispersion of matter in turbulent flow through a pipe: Proc., Royal Soc. [London] Proc., v. 223A, p. 446-468.

Gibson, C. H., and Schwarz, W. H., 1963, Detection of conductivity fluctuations in a turbulent flow ficld: Jour. Fluid Mechanics, v. 16, p. $357-364$. 



\section{RECENT PUBLICATIONS OF THE U.S. GEOLOGICAL SURVEY}

(The following books may be ordered from the Superintendent of Documents, Government Printing Office, Washington, DC 20402, to whom remittances should be sent by check or money order. Give series number, title, stock number shown in parentheses in this list, and catalog number shown in brackets. Prices of Government publications are subject to change. Increases in costs make it necessary for the Superintendent of Documents to increase the selling prices of many publications offered. As it is not feasible for the Superintendent of Documents to correct the prices manually in all the publications stocked, the prices charged on your order may differ from the prices printed in the publications and in this list)

\section{Professional Papers}

529-L. Atlantic Continental Shelf and Slope of the United StatesSediment texture of the northeastern part, by John Schlee, 1973 (1974). p. L1-L64; plates in pocket. \$4.05. (2401-00280) [I 19:16:529-L]

754-C. The Portage Lake Volcanics (middle Keweenawan) on Isle Royale, Mich., by N. K. Huber. 1973 (1974). p. C1-C32. $\$ 1.05$. (2401-02399) [I 19:16:754-C]

774-B. Hetch Hetchy Reservoir quadrangle, Yosemite National Park, Calif.-Analytic data, by R. W. Kistler. 1974. p. B1-B15. 65d (2401-02462) [I 19:16:774-B]

777. Silurian rugose corals of the central and southwest Great Basin, by C. W. Merriam. 1973 (1974). 66 p.; 16 plates showing fossils. $\$ 2.15$ (24.01-00363) [I 19:16:777]

783. Oligocene stratigraphy, tectonics, and paleogeography southwest of the San Andreas fault, Santa Cruz Mountains and Gabilan Range, California Coast Ranges, by J. C. Clark and J. D. Rietman. 1973 (1974). 18 p.; plate in pocket. \$1.70. (2401-02378) [ I 19:16:799]

799. Middle Devonian rugose corals of the central Great Basin, by C. W. Merriam. 1973 (1974). 53 p.; 14 plates showing fossils. \$1.85. (2401-02374) [I 19:16:799]

814. Distribution of selected elements in surficial marine sediments of the northern Gulf of Mexico continental shelf and slope, by C. W. Holmes. 1973 (1974). 7 p.; plates in pocket. \$3.35. (2401-02427) [1 19:16:814]

824. Devonian carrier shells (Euomphalidae) from North America and Germany, by R. M. Linsley and E. L. Yochelson. 1973 (1974). 26 p.; 6 plates showing fossils. \$1.15. (2401-02370) [I 19:16:824]

831-A. History of geologic investigations, engineering design, and construction methods of the Harold D. Roberts Tunnel, Colo., by E. E. Wahlstrom. 1974. p. Al-A13; plates in pocket. $\$ 2.65$. (2401-02435) [I 19:16:831-A]
850. Geological Survey research 1973.1973 (1974). 366 p. $\$ 4.95$. (2401-02461) [1 19:16:850]

\section{Bulletins}

1328. Estimation of petroleum exploration success and the effects of resource base exhaustion via a simulation model, by L. J. Drew. 1974. 25 p.. 45 . (2401-02458) [I 19:3:1328]

1331-C. Petrography and stratigraphy of glacial drift, Mesabi-Vermilion Iron Range area, northeastern Minnesota, by T. C. Winter, R. D. Cotter, and H. L. Young. 1973 (1974). p. Cl-C41; plates in pocket. \$2.25. (2401-02387) [I 19:3:1331-C]

1394-A. Changes in stratigraphic nomenclature by the U.S. Geologica Survey, 1972, by G. V. Cohee and W.B. Wright. 1974. p. Al-A93. \$1. (2401-02450) [I 19:3:1394-A]

1394-D. Concepción and Palma Escrita Formations, western Puerto Rico, by D. H. McIntyre. 1974. p. D1-D9. 30\$. (2401-02437) [1 19:3:1394-D]

1394-F. Four newly named tongues of Eocene Green River Formation, northern Piceance Creek basin, Colorado, by D. C. Duncan, W. J. Hail, Jr., R. B. O'Sullivan, and G. N. Pipiringos. 1974. p F1-F13. 35ф. (2401-02457) [I 19:3:1394-F]

Water-Supply Papers

2029-A. Hydrogeology of glacial drift, Mesabi Iron Range, northeastern Minnesota, by T. C. Winter. 1973 (1974). p. Al-A23; plates in pocket. $\$ 2.10$. (2401-02419) [I 19:13:2029-A]

\section{Nontechnical Publications}

Ferdinand Vandiveer Hayden and the founding of the Yellowstone National Park. 1973 (1974). 48 p. $75 \&(2401-02396)$

Landslides. 1974. 8 p. 25ł. (2401-02447)

Permafrost, 1973 (1974). 16 p. 25ł. (2401-02433) 
POSTAGE AND FEES PAID

PUBLIC DOCUMENTS DEPARTMENT

U.S. GOVERNMENT

WASHINGTON, D.C. 20402

OFFICIAL BUSINESS

PRINTING OFFICE

PENALTY FOR PRIVATE USE $\$ 300$ 